
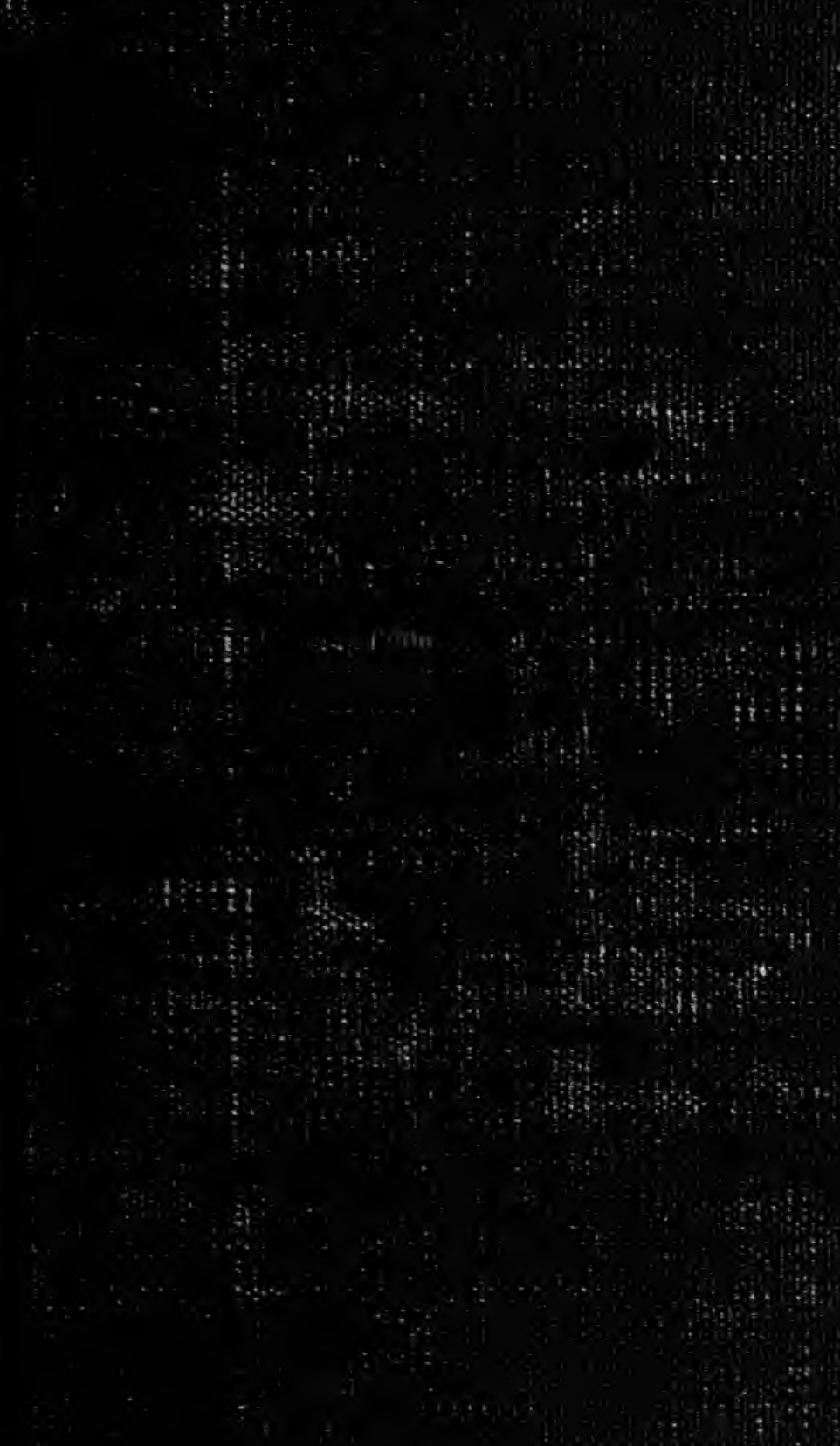

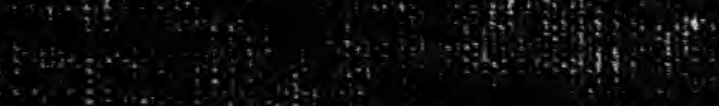




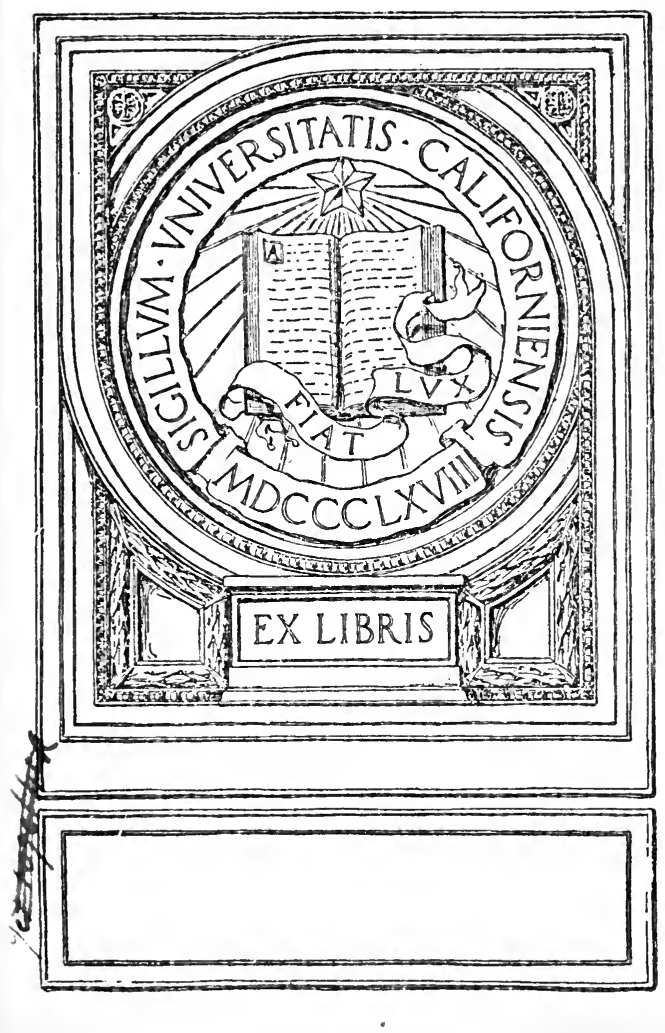




\section{Digitized by the Internet Archive in 2007 with funding from Microsoft Corporation}




\section{THE GOVERNMENT OF MODERN STATES}




\title{
AN INTRODUCTION TO THE STUDY OF -THE GOVERNMENT OF MODERN STATES.
}

\author{
BY \\ W. F. WILLOUGHBY \\ Director of The Institute for Government Research, \\ Late McCormick Professor of Jurisprudence \\ and Politics, Princetor University
}

\section{NEW YORK \\ THE CENTURY CO.}


Copyright, 1919, by

The Century Co.

Published, Jamuary, 1919 


\section{PREFACE}

The present work seeks to do two things: to set forth the problem of government as a problem; and to show how the leading States of the world have in practice met it. It is easy for students to learn a mass of facts regarding the structural character of different governments. It is exceedingly difficult, however, for them to interpret these facts, to see the fundamental principles lying back of them, and of which they are but the expression; in a word, to grasp the real significance of the differences in governmental organization and procedure and the consequences resulting therefrom. This difficulty arises from, or at least is aggravated by, the fact that government, as generally taught, is so preeminently a matter of description. Students are usually at once introduced to the study of particular governments without first having been given that background of knowledge of fundamental political principles which alone will enable them intelligently to interpret the facts learned.

If one surveys the field of political action, national and international, it is at once apparent that the great issues have been, and are, not over the details of governmental organization and modes of action, but over political principles whether one type of government or another shall prevail; whether final authority shall be deemed to reside in an autocratic ruler or in the mass of the people; on what basis shall the distribution of political powers take place as between the central, provincial and local governments, or between the several branches of government, the legislative, the exec- 
utive and the judicial; what shall be the proper function of the electorate, shall it adhere to the principle of representative government, or shall it seek by various devices itself directly to legislate and determine specific lines of action; what shall be the relations between mother countries and their dependencies; and scores of other questions of like fundamental import. The revolutionists in Russia, China, Turkey, Persia and elsewhere have not been struggling for a particular form of government, structurally considered, but for one resting upon essentially different principles from the ones under which they were living. The social democratic and liberal parties in Germany and Japan today are demanding, not a mere change in the mechanics of their governments but that the basic principle upon which such governments rest shall be changed, that sovereignty shall be held to reside in the people instead of an autocratic ruler claiming to hold his throne by divine right and to be responsible to God alone for the manner in which he exercises his powers. The present great war, as our President has so ably pointed out, is essentially one for the establishment of basic political principles: that the State exists for the welfare of the individual, not the individual for the State; that the end of all government is the promotion of the welfare of the individual; that in State, as well as individual, action the accepted canons of morality shall prevail; that peoples shall have a controlling voice in respect to the character of government under which they have to live and the policies that shall be pursued by such government.

No amount of study of the mere details of governmental structure and operation will enable students to think intelligently regarding these issues or to pass judgment upon the more or less radical measures of reform that are being 
proposed in respect to their own as well as foreign governments. If they are to be able to do this they must, in some way, have their attention concentrated on these issues and principles as issues and principles. In existing text books on government political principles have not been ignored, but they have not been disentangled from descriptive matter and so presented that their full purport is apparent.

The distinguishing feature of the present work is the attempt to meet this lack. In it, the problem of government is studied as a problem. The great end sought is to get clearly before the student the nature and terms of the problem that is presented to all peoples in seeking to organize themselves as States and devise machineries of government through which they can effectively act as such. The position is taken that, not until the terms of a problem are stated, can one intelligently consider the action that has been, or may be, taken in meeting it. With such terms clearly understood, little difficulty ought to be experienced by any student in appreciating the nature of any particular government or the features in respect to which it differs importantly from other governments.

The present work is thus essentially one of analysis. It seeks to resolve the problem of government as it confronts all peoples into its constituent elements; to show the alternative lines of action that are open in each case; and the reasons why one or the other has been chosen by individual States. In doing so, the principle of presentation adopted has been that of proceeding from the general to the particular. The author has sought to put himself in the position of a constituent assembly, or constitutional convention, beginning its work with a clean slate and free to bring into existence that form of government which it believes to be best adapted to the needs of the population on whose behalf 
it is acting. Such a body has to make its decisions in a certain order. It must determine whether the government to be created shall be one where sovereignty is deemed to reside in an autocratic ruler or in the people; whether the sum total of governmental powers shall be vested in one or a number of governmental organizations; whether there shall be a union or separation of powers; and like questions, before it can proceed to a consideration of the details of governmental organization and procedure. This is the order of treatment followed in the present work. In putting this plan into execution the effort has been made to maintain a due proportion between the importance of the points considered and the space given to them, while the fundamental problems of government are considered at some length. As the inquiry is pushed more and more into details the treatment becomes less exhaustive until, finally, little more than an enumeration of the points that must be considered in framing a system of government is attempted.

Washington, D. C., W. F. Willoughby.

November I, I9I8. 


\section{CONTENTS}

Preface

PART I: SOME FUNDAMENTAL CONSIDERATIONS

Chapter I. Introduction • • • •

The Study of Government one of Political Principles as well as of Mechanical Structure.

The Present World War one of Political Principles.

Distinction between a State and Its Government.

\section{Chapter II. The Nature of the State}

The State as an Abstraction.

Essential Characteristics of the State.

Desire on the Part of a Community that It Shall Constitute a Body Politıc.

Necessity that this Desire Shall find Actual Expression.

The State an Entity, Indivisible and Immutable.

Force or Compulsion as an Attribute of the State.

Law as an Attribute of the State.

The State as the Possessor of Supreme and Unlimited Authority: The Attribute of Sovereignty.

Significance of the Creation of a State: Surrender of Individual Wills to a Collective Will.

The Paradox of Freedom through Restraint: of Liberty through Law.

. Difficulty at Times in Determining whether a Given Community is a State.

So-called Non-sovereign States, Quasi-sovereign States, States with Impaired Sovereignty, Neutralized States, etc.

Distinction between a Federation and a Confederation: The Former a State, the Latter Not.

The American Civil War a Contest over the Nature of the State.

The State as the Possessor of Yersonality. Identical Character of the State in all Cases.

Present Importance of the Question of the Nature of the State.

Comparison of the Anglo-Saxon and Teutonic Theories of the State.

\section{PART II. TYPES OF GOVERNMENTS}

Chapter III. The Three Types of Government According to the Location of Sovereignty: Autocratic, Oligarchic and Popular • • • • • • • •

Unity of the Problem of Government.

The Location of Sovereignty.

Three Types of Government according to the Location of Sovereignty: Autocracy, Oligarchy and Popular Governments.

The Autocratic Type of Government.

The Doctrine of the Divine Right of Kings. 
Two Classes of Autocracies: Absolute and Limited.

The Oligarchic Type of Government.

The Popular Type of Government.

Historical Development of the Doctrine of Popular Sovereignty.

Popular Government a Question of Fact: Need not be Expressly Declared in the Constitution.

Popular Government Possible in a Monarchy.

Comparison of the Two Types of Government: Autocracy and Popular Government.

Tendency for the Doctrine of Popular Sovereignty to Prevail.

The Struggle for Popular Government in Germany and Japan.

Chapter IV. The Two Types of Government According to the Manner of Exercise of Sovereignty: AbsolUte AND CONStitutional • • • • • • • • . 72

Distinction between Governments of Authority and Governments of Law.

Absolute and Limited Autocracies.

Absolute and Limited Popular Governments.

Constitutional Government.

Chapter V. The Two Types of Popular Government: Democracy and Representative Government . . .

Definition of Democracy.

Inherent Limitations of Democracies.

Representative Government.

Mixed or Democratic-Representative Government.

The Government of England the Purest Example of a Representative Government.

The Government of the United States a Representative Government in Principle.

The Contest between the Principles of Democracy and Representative Government in the United States.

\section{PART III: THE ESTABLISHMENT OF GOVERNMENTS}

\section{Chapter Vi. The Formulation of Constitutions . • . \\ Governments Established through the Formulation of Constitutions. \\ Written and Unwritten Constitutions. \\ Methods of Establishing Constitutions. \\ Establishment of Constitutions by Grant. \\ Establishment of Constitutions by Deliberate Creation. \\ Establishment of Constitutions by a Process of Gradual Evolution. \\ Establishment of Constitutions by Revolution. \\ Dual Character of Revolutions: A Revolt against Existing Govern- mental Conditions and a Movement to Establish a New Type of Government. \\ Difficulties in Establishing a Government by Revolution.}

Chiapter VII. The Modification of Constitutions

The Question of Policy in respect to the Ease with which Constitutions may be Modified.

Stability a Prime Requisite of any Constitutional System.

Flexibility also a Requisite of a Constitutional System. 
Two Methods of Securing both Stability and Flexibility: Proper Draft. ing of the Collstitution and Provision of Adequate Means for Lf. fecting Constitutional Changes.

The Constitution of the United States a Model of Proper Urafting.

Defective Character of the Constitutions of Many of the States of the United states trom tue Standpoint of L'roper Draiting.

Early Constitutions Characterized by Excessive Rigidity.

Present Iendency towards ivore lilexible Constitutions.

Two Methods of Modifying Constitutions: By Formal Act and by In. formal Action.

Modification of Constitutions by Formal Act.

Distinction between (onstituent and Legislative Powers.

Distinction between Constituent and Legislative Powers and the Manner of Their Exercise the Prime Factor in Determining Methods of Modifying Constitutions.

System of Complete Surrender by the Electorate of the Exercise of Constituent Powers to the Government.

Complete Surrender to the Ciovernment of the Exercise of Constituent Powers may or may not Involve Abolition of the Legal Distinction between Constituent and Legislative lowers.

The English System an Example of Complete Surrender to the Government of the Exereise of Constituent Powers and 1 bolition of the Legal Distinction between Constituent and Legislative Powers.

The French System an Example of Complete Surrender to the Govern. ment of the Exercise of Constituent Powers with Maintenance of the Legal Distinction between Constituent and Legislative Powers.

System of Retention by the People of Participation in the Exercise of Constituent Powers.

Distinction between the Revision and the Amendment of Constitutions.

The Revision of Constitutions.

The Amendment of Constitutions.

Distinction between the Initiation, Adoption and Ratification of Amendments.

The Initiation of Amendments.

The Adoption of Amendments.

The Ratification of Amendments.

Special Problems Involved in the Revision and Amendment of Constitutions of Federal Governments.

The Revision and Amendment of the Federal Constitution of the United States.

The Revision and Amendment of Constitutions of Autocracies.

Futility of the Attempt to Declare Certain Provisions of a Constitution Unamendable.

The Informal Modification of Constitutions.

\section{PART IV: THE DETERMINATION OF THE SCOPE AND POWERS OF GOVERNMENT}

\section{Chapter ViII. The Jurisdiction of Government . . . 149}

Dual Function of a Constitution: Determination of Jurisdiction of Government and Form of Government.

Twofold Character of the Problem of Determining the Jurisdiction of Government.

Three Methods of Providing for the Guarantee of Individual Rights.

The Method of the United States that of Definite Specification in its Constitution.

The Method of England that of Refraining from a Definite Statement of Individual Rights.

The Methods of France and Germany Analogous to that of England.

Comparison of the Two Methods.

The Method of Switzerland, Japan and China that of the Statement of Rights in the Constitution Subject to Further Legislative Determination.

The Nature of Individual Rights. 
Individual Liberty.

Property Rights.

Equality before the Law.

Political Rights.

Procedural Rights.

No Rights Atisolute.

Individual Rights versus Social Rights.

Fallacy in the Attempt to Justify the Guarantee of Individual Rights by an Appeal to Natural Law.

\section{Chapter IX. The Functions of Government . . . . I69}

The Five Schools of Political Thought.

The Anarchistic School.

The Individualistic School.

Attempted Distinction between the Essential and Non-Essential Functions of Government.

Rise of the School of Individualism.

The Collectivistic School.

The Socialistic School.

The Communistic School.

\section{PART V: THE ORGANIZATION OF GOVERNMENTS}

\section{Chapter X. The Distribution of Governmental Powers} TERRITORIALLY

The Unity of Government.

Necessity for the Distribution of Governmental Powers.

Twofold Method of Distributing Governmental Powers: Territorial and Functional.

Distinction between Adminiștrative Districts and Political Subdivisions.

System of Political Divisions of Modern Governments.

Analysis of the Problem of the Distribution of Governmental Powers Territorially.

Determination of the Authority by which the Territorial Distribution of Powers shall be Made.

Distinction between a Unitary and a Multiple Government.

Comparison of the Relative Merits of Unitary and Multiple Governments.

The Problem of Local Self-Government under a Unitary and a Multiple Government.

The Establishment of Multiple Governments due almost wholly to Historical Reasons.

The Multiple Governments of Central and South America.

Adoption of the Unitary Type of Government by South Africa and China.

Universal Tendency in Multiple Governments to Increase the Powers of the Central Government.

Interpretation of these Historical Facts.

Determination of the Powers of the Central Government and those of Constituent States in a Multiple Government.

Relations between the Central Government and those of the Constituent States in a Multiple Government.

Intergovernmental Relations in the United States.

Relations between the Central and the State Governments.

Relations of the States among Themselves

The Division of the Territory of a State into Major Political Divisions.

Division of the United States into States.

Chapter XI. The Distribution of Governmental Powers FunctonaLLY

Analysis of the Problem.

The Classification of Governmental Puwers. 
The Traditional Threefold Classification of Governmental Powers into Legislative, Judicial and Executive.

A More Satisfactory Classification that of a Fivefold Division into Electoral, Legislative, Judicial, Executive and Administrative.

The Electorate as a Distinct Branch of Government.

Administration as a Distinct Branch of Government.

The Question of the Union or Separation of Powers.

Status of Organs Exercising the Several Powers in the Two Types of Government: Those of Union of Powers and Separation of Powers.

Distinction between a Personal and an Organic Union or Separation.

The English Government One of Separation of Powers Organically and Union of Poweŕs Personally.

The United States Government One of Union of Powers Organically and Separation of Powers Personally.

Comparison of the Systems of a Union and a Separation of Powers.

\section{PART VI: THE ORGANIZATION OF THE SEVERAL BRANCHES OF GOVERNMENT}

\section{Chapter XII. The Electoral Branch • . • . . 27 I}

The Electorate the Foundation of Popular Government.

Determination of the Composition of the Electorate.

Determination of the Electorate a Matter of Expediency: The Electoral Franchise not a Natural Right.

The Electorate in a Popular Government the Actual Possessor of Legal Sovereignty.

The Right of Revolution.

The English Reform Act of 1832 Forced by Threat of Revolution.

The Right of Revolution as Illustrated by Dorr's Rebellion in Rhode Island in $184 \mathrm{I}$.

The Problem of Electoral Procedure.

\section{Chapter Xili. The Legislative Branch • • • • • 289}

Analysis of the Problem.

Determination of the Functions or Duties of the Legislative Branch.

Congress as a Constituent Assembly or Constitutional Convention.

Congress as a Canvassing Board and Electoral College.

Congress as an Organ of Public Opinion.

Congress as a Board of Directors of the Government Corporation.

Congress as an Organ of Legislation.

Congress as an Executive Council.

Congress as a High Court of Justice.

Determination of the Structural Character of the Legislative Branch; Unicameral or Bicameral Legislature.

Historical Development of the Bicameral System.

Comparison of the Unicameral and Bicameral Systems.

Determination of the Composition and Method of Selection of Members of the Legislative Branch.

The Question of Size.

The Length of Term of Members.

The Qualifications of Members.

The Method of Selection of Members: The General Ticket and District Plans.

The Question of Minority or Proportional Representation.

The Requirement of a Majority or a Plurality in order to Elect.

Determination of the Life or Duration of Legislatures.

Determination of the Powers and Privileges of Legislatures.

The Determination of the Methods of Procedure of Legislatures. 
Chapter XIV. The Executive Branch . . . . . . 338

The Functions of the Executive Brancli.

The Office of Chief Executive.

Qualifications of Chief Executive.

Method of Selection of Chief Executive.

Election of Chief Executive by Popular Vote or a Plebiscite.

Election of Chief Executive by the Legislature.

Election of Chief Executive by a Specially Constituted Electoral College.

Succession to the Office of Chief Executive.

The Independence of the Chief Executive in the Performance of His Executive Duties.

Relations of the Chief Executive to the Other Branches of Government.

The l'residential Type of Government.

The Responsible Type of Government.

Comparison of the Two Systems.

\section{Chapter XV. The Judicial Branch • • • . . .}

The Function of the Judicial Branch.

Courts as Bodies to Investigate and Determine Facts.

Courts as Bodies to Apply the Law to Ascertained Facts.

Courts as Bodies to Determine and Construe Law.

Courts as Bodies to Prevent Infractions of Law and Violations o: Rights.

Courts as Bodies to Administer Property.

The Organization of a System of Courts.

Judicial Procedure.

The Problem of an Independent Judiciary.

\section{Chapter XVI. The Administrative Branch • • • 385}

Non-political Character of the Administrative Branch.

Distinction between the Function of Direction, Supervision and Control and that of Execution.

Congress as a Board of Directors.

Organization and Administration of the Administrative Services.

Problems of Organization.

Problems of Personnel.

Problems of Matériel.

Problems of Business Practice and Procedure.

\section{Chapter XVII The Role of Political Parties in Modern} GovernMENTS

Political Parties a Recent Phenomenon.

Political Parties First Viewed as an Evil.

Political Parties not a Deliberate Creation of Law.

Distinction between Political Parties inside the Government and Outside the Government

Two Principles of Representation: The Representative and the Agency.

The System of Political Parties in England

The System of Political Parties in the United States.

Comparison of the Party System in England and the United States.

The Two-Party System.

Collective versus Individual Responsibility.

The System of Political Parties in France and other Latin Countries of Europe.

The System of Political Parties in Germany.

The System of Political Parties in Switzerland.

The Rôle of Political Parties in the Establishment of Governments. 


\section{PART I \\ SOME FUNDAMENTAL CONSIDERATIONS}




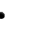




\section{THE GOVERNMENT \\ OF MODERN STATES}

\section{CHAPTER I}

INTRODUCTION

The Study of Government One of Political Principles as Well as of Mechanical Structure.-In entering upon any study the standpoint from which it is approached is of supreme importance. Examination of the problem of the study of government shows that such study, if properly prosecuted, should do two things: it should make known the character of the institutions made use of by States for the conduct of their affairs, how these institutions have come into existence, the nature and source of their powers and the manner of their operation, and it should reveal and make clear the significance of the fundamental principles lying back of these institutions, the motives that have led to their selection, and the aim that it is sought to accomplish through them; in a word, their inner spirit. Thus, to illustrate, it should make known to students, not only that most States, in organizing the legislative branch of their governments, have made provision for one of two houses, but why they have made this choice, what are the advantages which are supposed to inhere in a bicameral, as opposed to a unicameral, legislature, what are the disadvantages, if any, which such a system presents, whether 
such a system is one offering superior advantages under all, or only certain, conditions, and whether the conditions now obtaining are such as to justify the continued use of this system. Government, in a word, should be so studied as to make a constant appeal to the analytical and reasoning powers of the student. No pains should be spared to make known the principles which those responsible for determining the structural character of governments have sought to put into application, the relative merits of these principles, and the success secured as measured by actual results obtained.

The Present World War One of Political Principles. - Important at any time, a study of government from this viewpoint is especially desirable at the present moment when the nations of the world are engaged in a titanic struggle, in which the great issue at stake is, not the character of government, mechanically viewed, that shall prevail, but the fundamental political principles that shall find expression in all governments in the years to come. It is vital that all Americans, and, if possible, all the peoples of the world, shall know what is the real meaning of that great declaration of our President, in stating our reasons for entering the war, that the world must be made safe for Democracy, and all the implications contained in it. The governments of the United States and our western allies differ from those of the central European powers to which we are opposed, not merely in respect to the structural character of their political institutions, but in the basic principles upon which these institutions are founded. The most important fact to be learned regarding these governments is, then, the difference in these principles and why we hold that in our principles is to be found the only firm foundation for those things which alone make existence worth 
while - individual liberty, justice, and the protection of national rights of all States, strong and weak - while, in the principles lying back of the governments of our enemies, is to be found a continued threat against these great ideals.

Distinction Between a State and Its Government.It is unfortunate that in beginning most studies, attention must first be paid to the definitions of the more important terms that will be employed, to the drawing of certain primary distinctions, and to the consideration of certain abstract principles which lie at the very basis of such studies. The task is one which, however, cannot be avoided if clearness of exposition and thinking is to be subsequently secured. This is particularly true of political science which, in common with other social sciences, has always suffered the grave disadvantages of a loose use of terms and a failure on the part of writers to agree upon the very foundation conceptions upon which a study of this science must rest. In this part of our work we will, however, be as brief and summary as due regard to the points that must be made clear will permit.

In the study of political science constant use is made of the terms "People," "Nation," "State," and "Government." Though these terms are often used interchangeably, they connote quite different conceptions and should be clearly distinguished.

Much the most concise, and at the same time clearest, statement of the distinctions between these several ideas and terms with which the writer is familiar, is that contained in the introductory chapter of the "American Constitutional System," by the writer's brother. ${ }^{1}$

An aggregate of men living together in a single community and

1 W. W. Willoughby: "The American Constitutional System" (American State Series), pp. 3-4. 
united by mutual interests and relationships we term a Society. When there is created a supreme authority to which all the individuals of this society yield a general obedience, a State is said to exist. The social body becomes, in other words, a Body Politic. The instrumentalities through which this superior authority formulates its will and secures its enforcement is termed a Government; the commands it issues are designated Laws; the persons that administer them, Public Officials, or collectively, a Magistracy; the whole body of individuals, viewed as a political unit, is called a People; and finally the aggregate of rules and maxims, whether written or unwritten, that define the scope and fix the manner of exercise of the powers of the State, is known as the Constitution. The State itself then is neither the People, the Government, the Magistracy, nor the Constitution. Nor is it indeed the territory over which its authority extends. It is the given community of given individuals, viewed in a certain aspect, namely, as a political unity.

Of these distinctions much the most important is that between the State and Government. The State, to use the term employed in political science, is the Body Politic. The Government is merely the aggregate of the instrumentalities employed by such body in performing its functions. To appreciate the significance of this distinction and its bearing upon the problem of government, it is necessary that we should have a clearer idea of precisely the nature of this body to which the term State is given. 


\section{CHAPTER II}

THE NATURE OF THE STATE

The State as an Abstraction.- A close reading of the definition of a State as given in the preceding chapter will show that the State is almost an abstraction. It is not the territory over which a single political authority holds sway; nor the inhabitants of that territory; nor the collectivity of the instruments through which it manifests itself tangibly. It is, if the expression may be permitted, the thing itself, as distinguished from its parts or outer garments. It is, as the author quoted has so aptly put it, "the given community of given individuals viewed in a certain aspect, namely, as a political unity."

Essential Characteristics of the State.- The foregoing definition carries us but a short way. towards an understanding of the nature of the State. To secure such an understanding, it is necessary to examine more closely what are the essential characteristics of this body, which is at once a reality and an abstraction; or, to put it in another way, to determine what features must be present before one is entitled to hold that a given community constitutes a State.

Many attempts have been made by writers on political science to consider this subject. For the most part this consideration is unsatisfactory, due to the fact that they have failed to distinguish with sufficient accuracy between those features which are usually present, such, for example, as that a State is composed of a numerous assemblage of 
persons, and occupies a determined territory, and those which are essential; that is, that must be present if a State can be said to exist. In the consideration that follows it will be our effort to indicate and discuss only those features which constitute essential characteristics in this sense. ${ }^{1}$

Desire on the Part of a Community that It Shall Constitute a Body Politic. - The first and prime characteristic of a State is that there shall exist in a community a desire that it shall collectively constitute a body politic. By this is meant that the people composing the community shall appreciate, or acquiesce in, the desirability that there shall exist a central authority which shall exercise powers in respect to, and on behalf of, all the members composing the community. Such an authority is termed the political authority, the power exercised by it, political powers, and the community of persons viewed from this standpoint, a body politic or a State.

As the author quoted clearly puts it: ${ }^{2}$

A State owes its existence to the fact that, in the individuals over whom its authority extends, there is a sentiment of unity sufficiently strong to lead them to surrender themselves to the control of a single political power for the sake of realizing the desires to which such a sentiment gives rise. In other words, this subjective condition first comes into being, and when sufficiently powerful, finds objective manifestation in the creation of a political organization.

In most cases a desire or acquiescence of this character has come into existence unconsciously. Only in a few and very

${ }^{1}$ That the possession of a determined territory is not an essential characteristic of a State is evidenced by the recognition on the part of the "Allies" that the Czecho-Slovaks constitute a State though they are at present in the possession of no defined territory.

${ }^{2}$ Op. cit., p. 6. 
exceptional cases has a community, politically unorganized, determined, as a matter of deliberate action, to constitute itself into a body politic. Certainly the most remarkable, if it is not an unique, example of where action of this character has been taken, is that whereby the Pilgrims on the Mayflower in 1620 assembled and affixed their names to a solemn covenant by which they bound themselves to constitute themselves a body politic, and to yield obedience to the political authorities that should be selected to exercise the powers of that body. This famous agreement in modern English reads:

In the name of God, Amen: We whose names are underwritten, the loyal subjects of our dread sovereign, Lord King James, by the Grace of God, of Great Britain and Ireland, King, Defender of the Faith, etc., having undertaken for the glory of God and advancement of the Christian faith and honor of our king and country, a voyage to plant the first colony in the northern part of Virginia, do by these presents solemnly and mutually, in the presence of God and one another, covenant and combine ourselves together into a Civil Body Politic for our better ordering and preservation and furtherance of the ends aforesaid; and, by virtue hereof, to enact, constitute and frame such just and equal laws, ordinances, acts, constitutions and offices from time to time as shall be thought most meet and convenient for the general good of the colony unto which we promise all due submission and obedience.

In witness whereof, etc.

The fact that allegiance was pledged to the King of England and no intention was manifested of creating an independent political authority in one sense prevents this act from being an example of the deliberate creation of a State in the fullest acceptation of the term. It does furnish, however, an excellent example of what is meant by the necessity that there shall exist on the part of a community a de- 
sire to constitute itself into a body politic, in order that a State may come into existence.

Of this act John Quincy Adams said:

This is perhaps the only instance in human history of that positive, original, social compact which speculative philosophers have imagined as the only legitimate source of government. Here was a unanimous and personal assent by all the individuals of the community to the association by which they became a nation (i.e. State).$^{1}$

At the present time we have a number of striking instances where this initial step looking towards the creation of a State is being taken. In the territories formerly ruled over by Russia and Austria-Hungary various peoples having a common race origin are making known their desire that they shall become independent States. Of these the Finns, Poles, Czecho-Slovaks, and Jugo-Slavs are apparently on the way towards success. Whether other peoples, such as the Ukrainians, will be equally successful still remains uncertain. Few issues of the present war are more important than that of the extent to which its outcome will be the addition of new States to the commonwealth of nations.

Necessity That This Desire Shall Find Actual Expression.- Though the desire on the part of a community that it shall constitute a body politic constitutes the fundamental condition that must be present if a State is to come into existence, that desire alone is not sufficient to accomplish this result: it must find expression in actual action. It is thus probably true that the people of Poland desire ardently that they shall constitute a separate body politic. The same is also probably true of other peoples. In neither case, however, does a State result. In order that a State

1 Quoted in Goodwin's “The Pilgrim Republic," Boston, I888. 
may come into being, it is necessary that the community having the desire to be a body politic shall actually proceed to organize itself as a State, and to bring into existence a government through which the State may act.

The State an Entity, Indivisible and Immutable.- A third feature characteristic of the State is that it possesses a unity which is indivisible and immutable. It is like the individuality of a person. It is complete in itself ; it cannot be shared with any other body; it is incapable of being either divided or of undergoing change. It is in respect to this characteristic that it is so important to distinguish between State and government. A State can change its government as often as it desires as an individual changes his clothes, without itself undergoing any change. It can make use of one system of authorities for the administration of its affairs, as is done where the system of government adopted is the type known as unitary, or it can make use of two schemes, as is done where what is known as a multiple or federal form of government is established, without affecting in the slightest the character of the State.

This point is of special importance since almost invariably the mistake is made by writers on political science of designating a State having a unitary government as a Unitary State, and one having a federal government as a Federal State. This is exceedingly unfortunate since it obscures the essential nature of the State and its distinction from government. If we understand the real nature of the State, we must see that the distinction there sought to be made is impossible. The very conception of the State implies unity, indivisibility.

There is thus a State of the United States, notwithstanding its federal form of government, that is as definitely a unit as the State of France, or any other State having a 
unitary government. The fact that the people of the former have preferred to bring into existence two schemes of government for the conduct of their political affairs, while those of the latter have preferred to make use of but a single system, represents merely a difference of choice in respect to means to be employed, not different in kind from all other differences in governmental detail, no matter how apparently insignificant.

Force or Compulsion as an Attribute of the State.Another attribute universally ascribed to the State is that of force or compulsion, or rather the right and the obligation to make use of such force as may be necessary to insure that its will when duly expressed is carried into execution. Manifestly the mere possession of authority would be meaningless without the power to make this authority prevail. This a State can only secure when it has the power and the right to use such power as may be necessary to compel compliance with its'mandates. Not only must the State thus possess the right to employ force in order to compel compliance with its orders, but it, as the possessor of supreme authority, alone determines the form that the compulsion will take and the instrumentalities that will be employed in its exercise. One of the great problems presented to a State in establishing for itself a government is to determine the means that shall be made use of by it for enforcing its will.

Law as an Attribute of the State.-Another feature claimed to be characteristic of the State is that it not only exercises its authority through the formulation, promulgation, administration and enforcement of general orders which are known as laws, but that, from a strictly juristic sense, it is the sole source of law. As it is expressed by the author's brother in the passages from his book that 
have been quoted, "The commands that it (the State) issues are designated laws. . . . In the entire body of laws of a State are summed up the powers of the State as actually exercised."

It is very much of a question whether this is strictly so. When one speaks of law as an essential characteristic or attribute of the State one has in mind primarily the modern State as it exists in the West. If we turn to the East, such as it was before it began to westernize its political institutions, we find undoubted States in which law, as that term is properly employed in a juristic sense, plays but a a minor or secondary rôle. Here, as will be later pointed out, the State has brought into existence a type of government known as an Absolutism. It is the prime characteristic of such States that the organ through which they exercise all their powers, the ruler or sovereign, can and does act in an autocratic manner; that is, he is bound by no law and governs, not through law, but by the exercise of his arbitrary will. There can be no question but that such a community constitutes a State in the fullest acceptation of the word. But it would be hard to say that his commands, when each command may relate to but a single individual or act, and may vary as they relate to different individuals and acts, as his arbitrary will dictates, are entitled to be designated laws. Indeed this fact, whether the affairs of State are, or are not, conducted through the issuance and enforcement of laws, constitutes the essential difference between the two great classes of governments into which all governments are primarily divided.

It is thus well to think of law as an attribute of the State in the sense that the latter is the true source of all law, but it should at the same time be borne in mind that a State can exist and discharge its function without making any, or 
only incidental use, of this instrumentality. It is in the adoption of the policy of governing through law that the greatest advance has been made in the evolution of government.

\section{The State as the Possessor of Supreme and Unlim-} ited Authority: The Attribute of Sovereignty.-Another essential feature of the State is that it possesses an authority which is at once supreme and unlimited or, to use a legal expression, a jurisdiction the scope and extent of which is unlimited. TThis attribute of supreme and unlimited authority is designated in political science as Sovereignty. It constitutes by far the most essential and characteristic feature of tha State. As the writer's brother expresses it: ${ }^{1}$

The one characteristic that is essential to the State, and serves to distinguish it in toto genere from all other human associations, is its possession of political sovereignty. By political sovereignty is meant, on the one hand, complete freedom from the legal control of any other power whatsoever, and, on the other hand, absolute and exclusive control over the legal rights and obligations of its citizens individually considered or grouped into larger or smaller associations. The State is thus supreme, not only as giving the ultimate validity to all laws, but as itself determining the scope of its own legal powers and the manner of their exercise. . In every politically organized community that is entitled to be termed a State there must exist thus an authority to which, from the legal standpoint, all interests are potentially subject. In the entire body of laws of a State are summed up the powers of the State as actually exercised.

It is impossible to lay too great stress upon the importance of this attribute of sovereignty of the State. Supreme, final authority must lie somewhere, and, in a 
politically organized community, it lies in the State. It is in respect to this attribute that we see the essential difference between the State and the government. The authority of the State is unlimited; that of the government only such as the people acting as a body politic, that is as a State, choose to confere upon it. The State is the principal with inherent unlimited powers; the government an agent with only such powers as its principal may choose to confer upon it and those powers moreover it can exercise only in the manner prescribed by the State.

It is in respect to this attribute, and the distinction in respect to its possession between the State and the government, that one must view the whole great question of the enunciation and guarantee of so-called individual rights. There is no such thing as the protection of individual rights or liberties against the State. As Professor Burgess has excellently put it : ${ }^{1}$

The individual is defended in this sphere against the government by the power that makes and maintains and can destroy the government, and by the same power through the government against encroachment from any other quarter. Against that power itself, however, he has no defense.

\section{Significance of the Creation of a State: Surrender of} Individual Wills to a Collective Will. - Accustomed as we are to living as members of a State, and having known no other condition, it is difficult for us to realize the profound significance of this act by which a people is converted into a body politic and a State is brought into existence. We have seen that the State is a body having supreme, unlimited powers. The result of this is that it is

1 Burgess: "Political Science and Constitutional Law," I, I76, quoted by W. W. Willoughby, cp. cit., p. 5 . 
the final authority determining human conduct. There cannot be two supreme wills. The conversion of a people into a State means therefore that by this act the people have surrendered their individual wills as the final arbiter and determiner of conduct in favor of a collective will. Potentially, legally, the State can determine in the minutest detail the conduct and every act of the individuals composing it. The fact that no State in practice attempts to do this in no way alters the fact of the possession by the State of such powers. The fact is, however, that the State goes much further in this direction than is ordinarily appreciated. In the modern State one lives under an exceedingly elaborate body of laws. Only as one takes deliberate thought can he appreciate to how large an extent his acts are controlled, not by his individual will, but by the collective will of the State. He may seem to act freely but he acts within the orbit prescribed by the State and follows rules of conduct laid down by it.

What we now speak of as individual liberties are merely the liberties which the State, as a matter purely of policy or expediency, determines shall be left to individual determination. The power possessed by the individual in respect to these is in the nature of a delegated power. At any moment the State, acting through the machinery it has provided for itself, can enter this field and cancel the powers that it has granted or permitted. This it is constantly doing as emergencies, such as those caused by internal disturbances or foreign war, seem to make such action advisable.

The Paradox of Freedom Through Restraint; of Liberty Through Law. - This phenomenon that the establishment of a State means the absolute negation of individual liberty as an inherent individual possession; that, by 
the creation of a State, or acquiescence in the existence of a State, the individuals composing it substitute, or permit the substitution of, a collective will for their individual wills, is one which has given rise to a large amount of philosophical inquiry. The questions sought to be answered are: Why is it that individuals should thus abdicate as rulers of their own conduct in favor of an authority in which they as individuals can exercise but an infinitesimal voice? Why will they exchange a condition of independence for one of subjection? What is the justification, morally, for a collective will to control individual wills in the case of those individuals who generally, or in individual instances, are unwilling to recognize the validity of this collective authority?

It would take us much too far to attempt to follow out in detail the philosophical speculations to which these questions have given rise. They are mentioned here primarily for the purpose of making known to readers this interesting collateral field of political science. Here we will content ourselves merely with the statement that the solution of the questions propounded is to be found primarily in the paradox that, through the seeming surrender of individual liberty, the actual effective enjoyment of such liberty is increased; that, in a state of society, real freedom is only achieved through restraint; liberty through law. One or two examples will make this clear.

The freedom of an individual to go where he chooses is manifestly a reality only. when others stronger than he do not interfere with the enjoyment of this freedom. The freedom of an indivdiual to enjoy the fruits of his own labor is evidently but a theoretical freedom if any one stronger than he can freely take such fruits from him. In a condition of no-state, of no laws, real individual freedom, 
in the sense of power to do as one chooses, would thus be the possession of but the few who were possessed of superior strength. Only by law, by the restraint of these few by the exertion of a collective will, in other words by State action, can individual liberty or freedom be made a general possession. It is the appreciation of this, though such appreciation is more or less unconscious, that has led to the establishment of the State wherever man has emerged from barbarism. ${ }^{1}$

\section{Difficulty at Times in Determining Whether a Given} Community is a State. - No little difficulty arises at times in determining whether a given community possesses to a sufficient extent the desire to be a body politic, or, possessing the desire, has succeeded in establishing a governmental organization which is of sufficient definiteness and stability, and has been acquiesced in by the community as the true organ of the State to a sufficient extent to entitle such community to be designated a State and to receive recognition as such by other States. This question always presents itself when a people or a part of a people refuse allegiance to the existing political authorities and seek to bring into existence another organization for the expression and accomplishment of their political aims. The question is thus presented as to whether the Filipino Republic organized by Aguinaldo which the American forces were compelled to put down before establishing American rule in the Philippines was entitled to be designated a State. When a country is engaged in civil war does each side constitute a State? Did the Confederate States of America constitute a State?

1 For a consideration of this question see Dicey: "Law and Public Opinion in England in the Nineteenth Century," and W. F. Willoughby, "The Philosophy of Labor Legislation." Presidential Address, American Association for Labor Legislation, American Labor Legislation Review, March, I9I4. 
It is manifestly undesirable that we should bre'ck our consideration of principles to attempt to discuss in detail each of these special cases. As the decision is one resting upon facts as well as principles it is moreover doubtful whether a general agreement could be reached in all cases. The author believes, however, that in all cases where the desire to be a body politic is plainly present, and where a bona fide government has actually been organized for the conduct of political affairs, that community, from the standpoint of political science, is entitled to be designated a State, even though it has not succeeded in overcoming opposition from other communities to the maintenance of such a status. To the author the formal recognition of a State by other States is rather the general recognition of what already exists than in itself constituting an act essential to the coming into existence of a State.

So-Called Non-Sovereign States, Quasi-Sovereign States, States with Impaired Sovereignty, Neutralized States, etc.- One frequently hears the expression "Sovereign State" and, in contradistinction to these, States which are not completely sovereign, which have had their sovereignty impaired, etc. One thus hears the United States, Great Britain, France, and the other great powers of the world designated as Sovereign States while such nations as Cuba, China and Persia are referred to as States of Impaired Sovereignty, and still other nations, the political affairs of which are more or less controlled by some other power, as States which have almost wholly surrendered their sovereignty. In the interest of clear thinking it is important to determine the extent to which any such distinctions are warranted, or the sense in which they should be employed.

We have seen that sovereignty is an essential attribute of 
the State and that it represents supreme, unlimited and indivisible authority. This being so it is evidently impossible to speak of a Non-sovereign State, much less of one with impaired sovereignty. It is even tautological to speak of a Sovereign State. There can be no doubt about the differences in the conditions under which the powers of the several States which it is sought to distinguish in this way are exercised. Confusion arises in expressing these different conditions, partly through a failure to keep strictly in mind the essential nature of the true political State and of sovereignty as the most essential attribute of such State, partly through the use of the word State to designate given politically organized communities as distinct from the purely political or abstract conception of The State, and partly through the general mistake of describing sovereignty as constituting supreme, unlimited power instead of supreme, unlimited authority. Authority and power are two quite different things. A person or body may quite easily possess unquestioned authority but lack the power or the will to use it. This is true of actual States as well as of persons and other bodies.

If we keep these several distinctions clearly in mind we will, I think, have little difficulty in determining the true political status of those States whose sovereignty is alluded to as impaired or incomplete. Thus, for example, there can be no doubt that China, notwithstanding the fact of the extent to which other governments exercise the power of extraterritoriality within its boundaries, and its freedom of action, even as regards the management of its internal affairs, is restrained by treaty conventions, is a completely sovereign State. In so far as it voluntarily acquiesces in these arrangements it, as a State, exercises its supreme authority to say that the conduct of political affairs shall 
be had in this way. In so far as it resents such arrangements but feels itself without sufficient power to annul them, the latter represents an impairment of its power but not its inherent authority.

The same is true of Cuba. Cuba as a State has complete authority in respect to its political affairs, foreign as well as domestic. Acting as a State it has determined that in respect to certain features of its foreign affairs it will consult with and defer to the wishes of the United States.

As W. W. Willoughby expresses it: ${ }^{1}$

Sovereignty, as thus expressing the State's supreme will, is necessarily a unity and indivisible. That there cannot be in the same being two wills, each supreme, is obvious. But though the sovereign will of the State may not be divided, it may find expression through several legislative mouth-pieces, and the execution of its commands may be delegated to a variety of governmental organs. Theoretically indeed the State may go to any extent in the delegation of exercise of its powers not only to governmental organs of its own creation, but even to those of other States. Thus a given State may, in fact, retain under its own immediate direction only a most meager complement of activities and yet preserve unimpaired its sovereignty; for in such a case the public bodies or States to which the exercise of the powers has been granted, act as the agents of the State in question, and this State still possesses the legal, if not the actual, powers of again drawing to itself the exercise of the powers it has delegated.

Thus mother-countries may concede to colonies that most complete autonomy of government and reserve to themselves a control of so slight and negative a character as to make its exercise a rare occurrence, yet so long as such control exists the sovereignty of the mother country exists, and such colony is therefore to be considered as possessing no independent political powers. Again as we shall later see, in the so-called Confederate State, the member commonwealths may yield to the central government the exercise of their most important powers and yet retain their sovereignty,

1 Op. cit., pp. 5-6. 
and on the other hand, a National Federal State may, without destroying its sovereignty, yield to particular territorial authorities an extent of power sufficient to endow them, apparently, with almost all the characteristics of independent bodies politic.

Distinction Between a Federation and a Confederation: The Former a State; the Latter Not.- One of the most important points developed by the foregoing consideration of the nature and indivisibility of sovereignty is the distinction between what is known as a Federation or a Federal State, though this latter term is, as has been pointed out, an improper one, and a Confederation or, as the Germans express it, the distinction between a Bundesstaat and a Staatenbund. Both are made up of a grouping of large political units. In both the performance of the functions of the State is entrusted to two sets of governmental machinery, a general or central government which acts for all the units and a special government acting for each of the units independently of the others.

Notwithstanding this similarity, the two are, from the political standpoint, fundamentally different. The former is a single State, the latter is composed of as many separate States as there are units composing the grouping. This difference arises wholly from the differences in respect to the location of sovereignty in the grouping. In the true Federation or Bundesstaat sovereignty resides in the combined population of all the units. This population has, purely as a matter of practical expediency, decided to make use of two sets of governmental machinery for the performance of its functions: a central government to attend to matters which it is believed concern all, or should receive single generally-binding determination; and special machinery for each of the great geographical divisions into which the country, for historical or other reasons, is divided. Each of 
these governments is equally but the instrument through which the single State acts.

The Confederation or Staatenbund, on the other hand, is a mere league of sovereign States. The fact that there is a central government acting for all arises merely from the fact that the several States, though independent sovereignties, have agreed among themselves to make use of a common instrument for the performance of certain of their duties which, as a matter of practical expediency, they believe should receive a common determination. The association is thus a mere league. The tie binding the several units together is in the nature of an agreement which has been entered into, not by the combined population of the several units acting as a body politic, but by the several units acting as independent political units. The distinction between the two, it should be noted, is thus in no way the relative importance of the functions that are exercised by the central government and the governments of the constituent commonwealths. It is solely one of the sources of ultimate authority, of the location of sovereignty. As W. W. Willoughby puts it: ${ }^{1}$

The distinction between a National State with a federal form of government and a Confederacy of sovereign States is not based upon the quantum of powers, the exercise of which is vested in the central governinent; nor primarily whether the commands emanating from the central legislature operate directly upon individuals or upon the individual commonwealths; nor finally upon the difference between a central government with enumerated and one with unenumerated powers. The one absolute and finally determining criterion is: What authority has, in the last instance, the legal power of fixing its own legal competence, and, as a result, that of the others? 
to recapitulate in one compact statement the points that it has sought to bring out. Making such an attempt we may say that:

A State is a politically organized community, or to state it in another way, a community viewed as a political entity. It exists in virtue of the desire on the part of such community that it shall collectively constitute a body politic. Such desire means that there shall come into existence an entity known as a State which shall have supreme and unlimited authority over them, whether viewed collectively or individually. This entity, the State, has all the attributes of legal personality. It possesses a supreme will, means for formulating and expressing this will, and full powers to employ all force necessary to compel compliance with its commands. As a légal person it is a unity which is indivisible and unchangeable. To exercise its powers and to discharge its functions it brings into existence an organization or a machinery of administration which, viewed as a whole, is termed its government. This government may take an almost limitless variety of forms, but such variety in no way affects or alters the character of the State which itself remains invariable.

From the foregoing it must be apparent that when political writers speak of different kinds of States as Unitary States, Federal States, etc., they are guilty of loose thinking or loose language. There is no such thing as different kinds of States. The State of Great Britain, of the United States, of China, is precisely the same thing. States differ among themselves, not in respect to their essential nature, but merely in respect to the policies pursued by them in making use of their identical, inherent powers, and in the character of the organization employed, and rules of procedure followed, in their exercise. 


\section{Present Importance of the Question of the Nature of} the State.- It might seem that the foregoing consideration of the nature of the State had only a theoretical interest and could well be left to those who are primarily interested in speculative political philosophy. This, however, is not so. In point of fact the questions here involved are ones of great practical importance. We have already seen that, in a very real sense, the great contest between the North and the South was one over contending theories of the nature of the American State. Had there been no difference of opinion regarding this matter, it is conceivable that that contest might have been avoided. At the present time the questions here considered immediately arise wherever a new State is brought into existence or existing States undergo reorganization. It is impossible without keeping these considerations in mind to act intelligently upon such questions as the attitude that shall be taken towards those in control of the direction of affairs in Russia at the present time, towards the Czecho-Slovaks, the Jugo-Slavs and the Poles and their efforts to bring into existence autonomous States of their own. They are present in all questions of the relations of mother countries to their dominions, colonies and dependencies, and in the great questions, now becoming ones of supreme importance, of imperial federation, of leagues of nations and of the relation between States generally. They, indeed, constitute the very kernel of these problems. Most important of all, however, is the fact that the present world war finds its real cause in the fundamentally different conceptions held by the English peoples and, in large part, by their Allies, and that held by the Central European powers in respect to the true nature of the State, and what should be its aims. No adequate idea can be obtained of the real issues of this great struggle 
to recapitulate in one compact statement the points that has sought to bring out. Making such an attempt we ma say that:

A State is a politically organized community, or to sta it in another way, a community viewed as a political entit. It exists in virtue of the desire on the part of such con munity that it shall collectively constitute a body politi Such desire means that there shall come into existence a entity known as a State which shall have supreme and ur limited authority over them, whether viewed collectively c individually. This entity, the State, has all the attribut of legal personality. It possesses a supreme will, means $\mathrm{fc}$ formulating and expressing this will, and full powers $t$ employ all force necessary to compel compliance with i commands. As a legal person it is a unity which is in divisible and unchangeable. To exercise its powers an to discharge its functions it brings into existence an orgar ization or a machinery of administration which, viewed as whole, is termed its government. This government ma take an almost limitless variety of forms, but such variet in no way affects or alters the character of the State whic itself remains invariable.

From the foregoing it must be apparent that when $p c$ litical writers speak of different kinds of States as Unitar States, Federal States, etc., they are guilty of loose think ing or loose language. There is no such thing as differ ent kinds of States. The State of Great Britain, of th United States, of China, is precisely the same thing States differ among themselves, not in respect to thei essential nature, but merely in respect to the policies pur sued by them in making use of their identical, inherent pow ers, and in the character of the organization employed, an rules of procedure followed, in their exercise. 
Present Importance of the Question of the Nature of the State. - It might seem that the foregoing consideration of the nature of the State had only a theoretical interest and could well be left to those who are primarily interested in speculative political philosophy. This, however, is not so. In point of fact the questions here involved are ones of great practical importance. We have already seen that, in a very real sense, the great contest between the North and the South was one over contending theories of the nature of the American State. Had there been no difference of opinion regarding this matter, it is conceivable that that contest might have been avoided. At the present time the questions here considered immediately arise wherever a new State is brought into existence or existing States undergo reorganization. It is impossible without keeping these considerations in mind to act intelligently upon such questions as the attitude that shall be taken towards those in control of the direction of affairs in Russia at the present time, towards the Czecho-Slovaks, the Jugo-Slavs and the Poles and their efforts to bring into existence autonomous States of their own. They are present in all questions of the relations of mother countries to their dominions, colonies and dependencies, and in the great questions, now becoming ones of supreme importance, of imperial federation, of leagues of nations and of the relation between States generally. They, indeed, constitute the very kernel of these problems. Most important of all, however, is the fact that the present world war finds its real cause in the fundamentally different conceptions held by the English peoples and, in large part, by their Allies, and that held by the Central European powers in respect to the true nature of the State, and what should be its aims. No adequate idea can be obtained of the real issues of this great struggle 
without a clear appreciation of this difference. Involving though it has a dip into political philosophy it has thus been essential that we should have attempted to make this difference clear.

Comparison of the Anglo-Saxon and Teutonic Theories of the State. ${ }^{1}$ - The Anglo-Saxon theory of the State is an exceedingly practical one. It looks upon the State merely as an agency that is brought inte existence by a people for the promotion of their welfare as individuals. The State, in a word, exists for the people, not the people for the State. It conceives of the State as having no interests apart from those of its citizens. The promotion of individual welfare, individual liberty and individual rights constitutes thus the very foundation and justification of the State. It holds that, in general, the largest practicable freedom should be left to the individual in determining his affairs. It sanctions, however, the intervention of the State wherever the welfare of individuals generally will be thereby promoted. To be justified the necessity for such intervention should, however, be clearly and affirmatively established.

From the moral standpoint the State is viewed as being without morals; that is, non-moral. Moral responsibility for the acts of the State thus rests upon the persons having in charge the conduct of the State's affairs. No distinction in respect to moral obligations is thus made between the acts of officers of the State as such officers and as

${ }^{1}$ No writer has done so much as the brother of the present author in making clear the important bearing of the German political philosophy upon the present war. Especially notable are his two articles on "The Prussian Theory of the State," and "The Prussian Theory of Government," which appeared in the American Journal of International Law, Vol. XII, No. 2, April, 1918. Large use of these articles has been made in the present work. 
individuals. The same standards of honor, integrity and fair dealing should thus obtain in respect to acts of the State as in respect to those of individuals. Though moral responsibility attaches to the individuals acting as officers of the State rather than to the State itself, the highest regard is had for the honor of the State as representing the collectivity of its citizens, their ideals, achievements and reputation for honesty and fair dealing. Regard for the State and pride in its position in the world is thus of the same character as that held by individuals in respect to other bodies, such as the family, the church, the university or other organization of which they are constitutent members.

This conception of the State, and of the relations that should exist between it and its citizens, is one which it is held should be of general application. It recognizes no distinction between strong and weak States. The same standard of conduct should be maintained towards one as the other. It denies absolutely any justification for one State to impose its will upon another except in so far as such action is necessary to hold such other State to its obligations.

This conception of the State is so matter of fact and logical that it is difficult for the American or Englishman to understand how a different one can be held by any other people. Nothing, however, is more certain than that the conception of the State, its function, and its relations to its citizens, held by the German people, is different. To the Germans, and particularly the Prussians, the State is deemed to be something much more than a mere agent of the people for the protection and promotion of their common or collective interests. It is looked upon as an entity having interests, ambitions and a will of its own quite dis- 
tinct from those of its citizens collectively considered. These interests moreover, it is held, are superior to those of its citizens. To this entity the citizens owe implicit obedience. Whenever the interests of the State and its citizens come into conflict, those of the latter should give way. Being superhuman, as it were, it is neither itself bound, nor are those in charge of the conduct of its affairs bound, by the principles of morality governing in the case of human beings. Furthermore, the State is not only justified, but is under the obligation, as it were, to use its utmost powers to advance its particular interests no matter how much in so doing the interests of other States and even those of its own citizens, individually viewed, may suffer. In putting forth these efforts it knows no law of morality and no restraint but that of expediency.

"In juristic philosophy," writes the author's brother, "it has been found convenient in all countries, in order to give formal and logical consistency to their systems of public law, to envisage or picture the State as a political person or corporation possessing and uttering a legally supreme will, and thus in a formal and purely juristic sense, as the ultimate source of all commands that may in technical structure be termed laws. But this conception, which is nothing more than a convenience of thought, and which serves only as a peg upon which to hang other juristic concepts, or as a starting point from which to attempt a logical arrangement of public law principles, is an idea wholly different from the German doctrine which postulates the real, albeit mystical and insubstantial, existence of a State-Being to the commands of which, as a moral proposition, implicit obedience is due, and with ends of its own for the realization of which any and every sacrifice of individual well being might rightfully be required." 1

This conception of the State is one held not merely by the

${ }^{1}$ W. W. Willoughby: "The Prussian Theory of the State." American Journal of International Law, Vol. XII, No. 2, April, 1918, p. 253. 
relatively few ambitious statesmen holding the reins of power in Germany. It permeates all Germany philosophy. It has been taught in the schools and universities until it has become an essential part of the unconscious political beliefs of the people as a mass. Scores of quatations from German writers might be cited in support of it. Space will however permit of but one such, that from a work written since the outbreak of the present war by the professor of history at the University of Berlin. After dwelling upon the essentially different political conceptions of the English and Americans and the Germans, he says: ${ }^{1}$

The State is of much higher importance than any of these individualistic groups, and essentially is of infinite more value than the sum of all the individuals within its jurisdiction. For it has a life apart; its mission is unending, and, in theory at least, unless it is wrecked by a force from without, its existence is endless, encompassing, as it does, all the generations yet to come, and weilling them into a great unit - the mighty life of a nation acting its part in the history of the world. This conception of the State which is as much a part of our life as is the blood in our veins, is nowhere to be found in the English constitution, and is quite foreign to English thought and to that of America as well.

Combined with this idea of the State, as a political conception, is that of the belief generally held by the German people of the special superiority of their civilization or " Kultur" over that of other peoples' and of the mission of the German State to make this civilization prevail. With such a combination of conceptions it was inevitable that the policy of the German State should be one of aggression; that it should lose no opportunity to advance its authority.

1 "England: Its Political Organization and Development and the War Against Germany," by Edward Meyer, Ph.D., LL.D., Professor of History at the Unirersity of Berlin. Translated by Helene S. White, Boston, Ritter \& Co., 1916, pp. 30-31. 
In the pursuance of this policy it, as has been pointed out, felt under no restraint, moral or otherwise, except that of expediency. Believing that the time was propitious it took the steps which led to the present world conflict. 


\section{PART II \\ TYPES OF GOVERNMENT}




\section{CHAPTER III}

THE THREE TYPES OF GOVERNMENT ACCORDING TO THE LOCATION OF SOVEREIGNTY: AUTOCRATIC, OLIGARCHIC AND POPULAR

In the preceding chapter we have sought to do three things: to distinguish clearly between the State and its government; to make known the nature of the State and the different conceptions that are held regarding its mission; and to state the important consequences that may, and have, resulted from these different conceptions. This consideration, which has unavoidably been of a somewhat abstract character, was essential as a starting point, if one, in the study of government, is to gain an insight into fundamental political problems, as well as the more technical questions involved in the organization and operation of the machinery through which a State formulates, expresses and exercises its will. With this general idea of the nature of the State, we are now in a position to enter upon a consideration of this latter class of questions.

Unity of the Problem of Government.- In approaching this branch of our study the first point to be grasped is that the problem of government as a problem is identical, or practically so, for all States. The only difference that exists between States, governmentally considered, is in respect to the means that have been employed by them in meeting this problem. Manifestly, under this condition, it is desirable that the problem of government should, if possible, be clearly stated before the attempt is made to de- 


\section{6 THE GOVERNMENT OF MODERN STATES}

scribe and contrast the means employed by States in meeting this problem. Unless this is done it is difficult, if not impossible, for the student to grasp the significance of the different policies and lines of action that have been adopted by States in organizing and operating their governmental machinery. The present chapter will, therefore, be devoted to the attempt to state and analyze the problem of government as it confronts all States. This analysis, in addition to setting forth the terms of the problem, will render the further service of making known and classifying the several distinct types of government that have been created by the States of the world, one of the most important matters in the whole study of government.

The Location of Sovereignty.- Sovereignty, that is, the quality of supreme, unlimited, indivisible authority, constitutes, as we have seen, the prime or most important attribute of the State. Its conception is the starting point of all political science. The whole complex problem of government and administration, from one point of view, may be resolved into the single problem of determining in whose hands shall be vested the exercise of this authority, to what extent shall actual use be made of it, what shall be the instrumentalities or organs employed in its use, and what shall be the rules and procedure that shall be followed by such organs in performing their functions.

Of these several questions the first - in whose hands shall be vested the exercise of this authority - is much the most important, certainly the one to which an answer must be given before any other step can be taken by a community desiring to organize itself as a body politic and to establish a government through which political authority will be exercised. No political system can be understood except as its study is approached from this standpoint. Upon the 
nature of the action had in reference to this point depends the whole character and legal basis of the government resulting, the authority for every governmentai act, the manner in which this authority is determined in the first instance, and how it may be subsequently enlarged, curtailed and controlled.

\section{Three Types of Government According to the Loca-} tion of Sovereignty: Autocracy, Oligarchy and Popular Government. - An examination of the several governments of the world, past and present, shows that they may be made to fall into one or the other of three distinct classes according as one or another of three distinct principles in respect to the location of sovereign authority has been acted upon. These principles are: (I) that the source of all political authority, that is, sovereignty, is to be found in the ruler or head of the State; (2) that it resides in the hands of a special ruling class; and (3) that it is possessed by the general body of citizens. According as one or the other of these three theories or beliefs has been acted upon there have resulted three distinct types of government to which may be given the designations Autocratic, Oligarchic and Popular. ${ }^{1}$

The Autocratic Type of Government.- The autocratic type of government, as indicated, is that class of governments which rests upon the principle that the source of all political authority is to be found in a supreme ruler. Under this theory all the organs and officers of government are but the agents of this supreme ruler for the purpose of carrying out his will. All acts of government are his acts and derive their validity from his sanction. All laws are

1 We have preferred the term Autocratic to that more usually employed, Monarchical, to designate governments of the first class, since, as will shortly appear, it is quite possible for a Monarchy to belong to the Popular and not the Autocratic type. 
but his commands, though they may have been formulated and promulgated by one of his agents. As the possessor of sovereignty his authority is supreme, unlimited and selfdetermined, both as regards the extent to, and manner in, which it shall in fact be exercised.

This type of government is the one which finds its chief illustration in the absolute empires of the East. In the oriental despotisms of the past we see this theory, not only firmly established but acquiesced in by the people as an immutable political principle. The same is scarcely less true in respect to the kindoms of Europe as they existed prior to the great revolution in political thought that characterized the Seventeenth, Eighteenth and Nineteenth Centuries. It found its expression in the assertion by the Stuart Kings of England of their divine right to rule and in the proud boast of Louis Fourteenth of France that "L'état, c'est moi."

Few, if any, more fundamental changes in the history of mankind have occurred than the change of thought which took place in these centuries in respect to this question of the nature and location of sovereignty. Just as our civil war was fought over, or at least intimately involved, contending principles in respect to the location of sovereignty, so the great contests of this period, represented by the establishment of the Cromwellian Commonwealth, the Restoration, and the so-called Glorious Revolution of 1688 , which brought William of Orange to the English throne, and the French Revolution, represent, in their fundamental aspects, a contest of opposing principles in respect to where the sovereignty of the State should be deemed to reside. No greater mistake could be made than to look upon this question of the location of sovereignty as one of merely theoretical or speculative interest. It furnishes one of the 
important keys by which historical events are to be interpreted.

More important still is the fact that these contending principles are still playing a vital part in determining the character of present-day governments. The principle of popular sovereignty has by no means won the battle all along the line. In both the East and the West are to be found at the present day States, which are among the most enlightened and progressive in the world, having governments resting squarely upon this principle. In the East the leading example of a government of this character is that possessed by Japan. In I 889 Japan decided to abolish her old system of government and to establish in its place one corresponding to modern ideas as represented by existing governments of Europe and America. To this end she made a thorough study of such governments, sending a commission headed by Baron Ito for this purpose to study these governments on the spot. On the basis of this study and the report of this commission she adopted her present constitution. In framing this constitution the first question that she had to answer was in respect to this matter as to where supreme political power or sovereignty should be located. After careful consideration of the contending principles she made deliberate choice of the autocratic type; and that there might be no question regarding it she recorded her choice in unequivocal terms in her constitution, the preamble of which reads:

The rights of sovereignty of the State, we (the Emperor) have inherited from our ancestors and we shall bequeath them to our descendants. . . . When in the future it may become, necessary to amend any of the provisions of the present constitution, we, or our successors, shall assume the initiative right, and submit a project for the same to the Imperial Diet. The Imperial Diet shall pass its vote upon it, according to the conditions imposed by the present 
constitution, and in no otherwise shall our descendants or our subjects be permitted to attempt any alteration thereof.

\section{Article I of the Constitution itself reads:}

The Empire of Japan shall be reigned over and governed by a line of Emperors unbroken for ages eternal.

Baron Ito, in his " Commentaries on the Constitution of the Empire of Japan," explains the meaning of this as follows:

By " reigned over and governed" it is meant that the Emperor on his throne combines in himself the sovereignty of the State and the government of the country and of his subjects.

In the West the two most important examples of governments resting upon the autocratic basis are those of Russia before the Revolution of I9I7 and Prussia at the present time. The "Fundamental Laws of the Russian Empire," promulgated May 6, I906, though issued in response to a public demand for a more liberal form of government, were no less emphatic in stating this principle of autocracy than the constitution of Japan. Article IV of that document thus reads:

The Emperor of all the Russias wields the suprcme autocratic power. To obey his authority, not only through fear but for the sake of conscience, is ordered by God himself.

This principle is not set forth in the constitution of Prussia in the way that it is enunciated in the fundamental laws of Russia and Japan, but that this is the principle upon which the Prussian political system rests is no less strongly held. This is due in great part to the circumstances under which Prussia obtained its constitution. Historically all the powers of the State rested in the king's hands. $\mathrm{He}$, as a matter of state policy, promulgated on his own authority a 
constitution. It was his act and his act alone. The constitution was "octroyed," as the expression is, not adopted by the people. The king thus is not only the source of all authority now possessed by the various organs of the state, but is the possessor of all the powers, i.e., the reserved powers, not expressly delegated to other authorities.

The Doctrine of the Divine Right of Kings. - If one asks how it is that, not merely the ruler claimed to be the source of all authority, but this claim was acquiesced in by the people ruled, the answer must be found in the belief, long unquestioningly held, that the ruler got his authority direct from God, that he was God's vice-regent on earth, that he ruled by divine right. In China we see this belief expressed in all her literature during the thousands of years that she was a monarchy in the constantly reiterated statements that the Emperor was the "Son of Heaven," that he ruled in virtue of the mandate that he had received from Heaven. The fact that on various occasions a dynasty was forcibly overthrown and its place taken by another did not shake this belief. In all such cases the position taken was; that the deposed emperor had forfeited his right to rule by his weakness or misconduct; that Heaven had withdrawn its mandate and had conferred authority to rule upon his successful rival. No further proof of this was required than the fact that this rival had prevailed. That in itself was demonstration that Heaven had transferred its mandate to him. This reasoning is no more sophistical than that underlying the faith in the justice of the ordeal of battle which for centuries after the Norman Conquest prevailed in England. The whole basis for this faith was that God determined the right by permitting he who had the right on his side to prevail.

In scarcely less degree did this belief in the divine right of 
kings to rule prevail for centuries in Europe and England. It was in matters temporal strictly analogous to the belief in the supreme authority of the Pope as the direct representative of God on earth in respect to matters spiritual. As James Bryce has excellently stated it: ${ }^{1}$

From the Fifth to the Sixteenth Century whoever asked what was the source of legal sovereignty and what the moral claim of the sovereign to obedience of subjects would have been answered that God had appointed certain powers to govern the world and that it would be a sin to resist his ordinance.

From the Eleventh Century onwards it was admitted in Western Christendom, though less cordially in France, Spain or England than in Italy and Germany, that there were two legal sovereigns and, according to the view more generally held, each was de jure absolute, the Pope in spiritual, the Emperor in temporal matters. Both Pope and Emperor were above all positive secular law, but subject to the law of naturr and the law of God, these being virtually the same.

That this belief in the divine right to rule has not entirely disappeared can be seen in the constant reference to the Deity made by the present German Emperor in his state papers or public addresses. This frequent invocation of the Deity by him and assertion that he was carrying out the will of God has been a matter difficult for the American public to understand. Its explanation must be found in the persistence of the medieval doctrine which we have been considering. It is not so much a manifestation of deep piety as the assertion of a doctrine of political sovereignty.

Two Classes of Autocracies: Absolute and Limited.In the foregoing we have sought to get clearly before the reader, not only the theory of autocracy, but the extent to which this theory has in fact dominated political thought and

1 "Studies in History and Jurisprudence." 
action. That this theory has continued to prevail in the case of many nations is due to the fact that, though all political authority may be deemed to flow from the ruler, the belief and practice has constantly gained ground that this authority should not be exercised in an arbitrary manner, but in conformity to general provisions of law having for their purpose to insure that due consideration will be had of the rights and interests of the individual citizens. Autocracies, as will hereafter be shown, may thus be divided into two classes according as one or the other of two conceptions obtain in respect to the manner in which the ruler should exercise his supreme powers. The first of these is that the ruler not only is the possessor of supreme power, but is free to exercise it in such manner as he may see fit. The second is that, though possessing this authority in no less degree, the ruler should exercise it through regularly constituted organs and in conformity with general provisions of law. The government resulting from action on the first principle is a pure Absolutism, a Despotism, and its prime characteristic is that the ruler can act arbitrarily. The government resulting from the second is a Government of Law and may, in its practical operations, be of a scarcely less liberal type and permit of almost as wide a participation on the part of the public as that presented by a government resting upon the doctrine of popular sovereignty.

From the structural standpoint and that of its legal basis, it is immaterial whether this change from an Absolutism to the modern type of Autocracy has come about by voluntary act of the autocrat or in response to pressure from his subjects which he found it unwise to resist. Actually history shows that in most cases the change has been forced upon the autocrat either by revolution or threat of revolution. The summoning of the Duma by the Czar of Russia, fol- 
lowing the war with Japan, is the best modern example of how an autocratic ruler, without losing his legally autocratic powers, has been forced by pressure on the part of his subjects to bring into existence an organ through which his power is to be exercised to the end that his decisions and acts may be influenced to some degree at least by popular opinion. The summoning of this body in no way affected the location of sovereignty. It merely set up an organ through which sovereign power should be in part exercised.

A study of existing Autocracies, such as those of Japan, Prussia and other German states, will thus reveal the fact that these governments are equipped with popular assemblies and other organs, that they are in possession of constitutions and that their operations are conducted in conformity with law in the same way as governments resting upon the principle of popular sovereignty. This, however, should not blind us to their fundamental difference from the legal standpoint. This distinction, moreover, is not a mere legal technicality having a theoretical value only. It is one of prime practical significance. In an Autocracy the ruler, as has been pointed out, is the source of all political and legal authority. It follows from this that all other organs of government have no inherent powers. They have only such powers as have been expressly granted to them. The scope of their authority is thus strictly limited by the terms of the order by which they have been brought into existence and their powers and functions defined. All such organs and authorities are thus organs of enumerated, delegated and restricted powers. Through their own action they have no power to add to, subtract from, or modify their authority. The ruler, on the other hand, has a legal status exactly the reverse of this. His powers are inherent, unenumerated and unlimited. To justify any act he does not have to show 
any grant of authority. From this flows the important consequence that all powers, the exercise of which he has not entrusted to some other organ, remain in his own hands. It is moreover a question whether he can finally divest himself of any of his powers as long as this theory of the organization of the State is maintained. In all cases where he has granted a constitution to his country, the matter thus remains an open one whether the continued operation of that constitution does not rest upon his will alone. What he has granted he can modify or take away.

This fundamental distinction between the two types of government and the consequences flowing from it has been excellently stated by the writer's brother in a contribution made by him to a recent symposium. ${ }^{1}$ Writing under the title of "The Relation of the Individual to the State" he says :

As opposed to this fundamental constitutional doctrine (of popular sovereignty) the monarchical (i. e. autocratic) theory of continental Europe is that the right of political rulership comes from above. It inheres in, and is an original right of the monarch, and, as such, in its exercise is ultimately subject only to the will of him who possesses it. It is true that Austria-Hungary, and the German Empire and its individual states, including Prussia, operate under formal written constitutions, but these instruments of government are regarded as themselves the creations of the royal or imperial will. It thus results that, not only may the constitutions be changed by an exercise of the royal or imperial will, but that the sovereign is regarded, not as the exerciser of enumerated delegated powers, but as the possessor of sovereign authority free from legal restraint in all matters in regard to which he has not seen fit to fix self-set limitations. This is the constitutional theory, whatever may have been the popular pressure which, historically speaking, may have led to the promulgation of the written constitutions.

1 "Problems of Readjustment after the War." D. Appleton \& Co., New York, 1915, pp. I09-112. 


\section{6

It further follows from this constitutional conception that the part played by the elected representatives of the people in the enactment of laws and in the adoption of public policies is quite different from that which is played in countries where constitutional systems are founded upon a democratic basis. According to the doctrine held by German jurists the people, through their representatives, participate, not in the creation of law, but in the determination of the contents of a proposition which is to be submitted to the sovereign for the exercise of his supreme legislative will. Essentially speaking then, the situation is this: The ruler, as a matter of grace and expediency, is pleased to learn the wishes of his people regarding a proposition of law or the adoption of a public policy, and to obtain such information regarding its wisdom as a representative chamber is able to provide; and these wishes and this information he necessarily takes into consideration in determining the exercise of his own sovereign will. But never does he regard these factors as controlling in any affirmative sense. So long as the constitution which he has promulgated exists, he agrees not to act contrary to its provisions with regard to the matters which are therein specified. But never for a moment does the German ruler admit himself to be under a legal, or even a moral, or political, obligation to give effect to any expression of the will of the representatives of the people of which he disapproves.

The Oligarchic Type of Government.-The second type of government, as determined by the location of sovereignty, is the Oligarchic. This type stands midway between the other two. In it sovereignty is held to reside, neither in the general body of the people, nor in a single divinely determined ruler, but in a certain privileged class. Mention is made of this type of government chiefly in order that our classification of governments according to the principle of location of sovereignty may be complete. In the past there have been comparatively few governments of this character, and none of any importance is to be found at the present time. Probably the government of Venice during the period of its existence as an independent power 
furnishes the leading example of a government of this type. The government of England, after the overthrow of the autocratic principle, which may be said to have been definitely accomplished by the Revolution of 1688 , and before the movement in the early part of the nineteenth century for the extension of the franchise to the mass of the people gained headway, approximated this type in practice, if not in theory. In most other cases where this type has existed the ruling class was closely identified with the priestly class and appeal to divine sanction for its justification was made in much the same way as the doctrine of the divine right of kings was evoked by Autocracies.

It is hardly necessary to point out that this form of government should be clearly distinguished from those cases where a small class has, by its superior strength or skill, secured control over the machinery of government. History affords many examples where this has taken place.

The Popular Type of Government.- The third type of government is the one in which the belief is held that sovereignty resides, neither in a single all-powerful ruler, nor in a special ruling class; but resides in the whole body of the people. It would be difficult to single out a more momentous event in the history of the evolution of governments than the change in both political thought and practice which has resulted from the rise and development of this principle. It constitutes the key by which is to be interpreted many of the most important events of modern history. It dominates and colors all political thought at the present time.

Historical Development of the Doctrine of Popular Sovereignty.- The origin of this doctrine is to be found in the early Greek and Roman Republics. In a very true sense their governments may be said to have rested on this 
principle. Even after the establishment of the Empire of Rome republican forms were long preserved and the fiction was kept up that the Emperors were elected by and represented the people. In time, however, both the form and the fiction disappeared. In place of the western doctrine of popular sovereignty arose the oriental conception of the autocratic monarch ruling by divine right. This conception ran parallel with that of the supremacy of the Pope in matters spiritual. The two in close alliance represented the doctrine of authority as opposed to that of reason, that in all matters the seat of authority was to be found in the Divine Being who excrcised this authority through his divinely appointed representatives on earth. One cannot understand the history of events in the Middle Ages without having this conception clearly in mind. In the claim of the Popes that in them resided sovereignty in respect to temporal as well as spiritual matters, and in their attempt to make good this claim, are to be found the explanation of the great struggle between the Church and the State which played so important a part during this period, a struggle which has not entirely died out at the present time.

The doctrine of papal supremacy received its great blow in the Reformation on the continent and the Furitan movement in England. About the same time a series of students and writers began to question the doctrine of the divine right of kings. While not directly questioning the right of kings to rule, they sought to find some warrant for their exercise of supreme power other than in a divine sanction. This they found in the theory of a supposititious or implied contract between the people and the ruler that the latter should rule over them, or in a hypothetical compact between the people themselves that they should be ruled over in this 
way. Chief among those elaborating this theory were Jean Bodin (I530-1596), Johannes Althusius ( I 557-1638) and Thomas Hobbes ( $1588-1679$ ).

It is not our intention to enter into any consideration of this very interesting theory. All that it is desired to do is to point out that here is afforded, not only the first serious attack upon the principle of the divine right of kings, but in the elaboration of the social compact or contract theory of government, the germ of the idea of popular sovereignty which was afterwards to play such an important rôle in historical movements and in the evolution of political thought.

The next great event in the development of this doctrine was the struggle in England between the Puritans and the Stuarts, marked by the establishment of the Cromwellian Commonwealth, the deposition and execution of King Charles I, the Restoration and the Revolution of I 688 which brought William of Orange to the English Throne. The significance of this latter event lay in the fact that for the first time was definitely established the principle, which has ever since been adhered to in England, that the King owed his throne, not to divine or inherent right, but to selection by Parliament, which latter body acted in this capacity as but the representative of the people. Today the English King holds office by virtue of an act of Parliament and it is within the authority and power of that body to make such change in respect to who shall occupy the throne, or indeed as to whether the monarchical form of government shall be maintained or not, as it sees fit. From this event therefore may be dated the definite establishment of the principle of popular sovereignty in England. It is characteristic of the English that action should in general precede theory. In the present case thus it may be said that the actual estab- 
lishment of the doctrine of popular government as the basic principle of the political system took place before the doctrine itself was consciously or deliberately adopted as a philosophical principle. Even to this day the English are unwilling to change many of the outward forms of administration which are the characteristic features of a purely autocratic type of government.

It remained, however, for the closing years of the Eighteenth Century to mark the rise to ascendancy of this principle. In bringing about this event too great importance cannot bu attached to the remarkable influence exerted by the preaching and writings of that forerunner of the French Revolution, Jean Jacques Rousseau. In his work entitled "The Social Contract" was definitely announced and asserted for the first time the principle of popular, or as it was more generally designated, national sovereignty. The French people, long restive under the abuses and oppressions of the old régime, nevertheless were held to allegiance to their king by the centuries-old belief in the divine right of their king to rule. Rousseau's influence shook this belief. His doctrine of national sovereignty furnished the philosophical basis for, and justification of, the Revolution. What might have been merely an effort to depose a ruler and select another who would give greater regard to the welfare of the people became a struggle for the establishment of individual liberties and the right of the people to rule.

This doctrine of popular sovereignty and individual rights found a fertile soil in the new world and was used by the American colonies in asserting their right to throw off allegiance to the British government. It is a matter of no little interest from this standpoint that the colonists in taking this step deemed it necessary to justify their action to the 
public and the world in their Declaration of Independence that they were but exercising a right which was inherently. theirs.

Popular Government a Question of Fact: Need Not Be Expressly Declared in the Constitution.- That a government may be a popular one it is not essential that the provision that sovereignty resides in the people shall be explicitly set forth in the constitution. In England no such provision is possible, since that country is without a formulated constitution. In the United States this provision is only indirectly set forth in the opening words or preamble of the constitution which declare that "We, the people of the United States ... do ordain and establish this constitution." In France also no direct declaration of popular sovereignty is to be found in her fundamental law. In all these countries, however, there cannot be the slightest doubt about the fact of the government being of the type resting upon this principle.

The most definite and clear assertion of popular sovereignty is probably to be found in the constitutions of Belgium and China. The former, adopted in $183 \mathrm{I}$, contains the provision:

Art. 25. All powers emanate from the people. They shall be exercised in the manner established by the constitution. . . .

The constitution of China, promulgated May I, I914, contains as the first two sections:

Sec. I. The Republic of China is composed of the citizens of the Republic.

Sec. 2. The sovereignty of the Republic of China originates in the whole body of the citizens.

\section{Popular Government Possible in a Monarchy.-Be-}


fore leaving this subject it is important again to draw attention to the fact that all governments monarchical in form are not Autocracies. It is quite possible, as the case of Great Britain evidences, for a Monarchy to belong to the category of governments resting upon the legal basis of sovereignty residing in the body of the people. In these cases the people, in meeting the problem of devising a government for the actual exercise of political powers, have chosen to create a form of government in which the chief magistrate shall bear a monarchical title, such as King, Emperor, etc., shall be selected in much the same manner, and have a tenure of office analogous to that of monarchs at the head of governments resting upon the principle of autocracy. It is evident that in such cases the monarch has no inherent authority. He has only such as has been granted to him by the sovereign people. $\mathrm{He}$ is but one of the agents through which the latter have elected to exercise their powers. This is true even though the people in the exercise of their discretion may have chosen to entrust to him the exercise of powers exceeding those of many rulers in autocratic Monarchies.

Comparison of the Two Types of Government: Autocracy and Popular Government. - These facts - that two opposing doctrines underly and represent the basic principle upon which rest all modern governments, and that the adoption of one or the other of these doctrines determines in the most fundamental way the essential character of the government resulting - render it desirable that the attempt should be made to state and evaluate their relative merits. To an American or Englishman who, from his earliest youth, has been trained to look upon Popular Government as an inherent right, and the only system possible of philosophic justification, this is not an easy thing to do. 
The mere statement of the practical advantages inhering in an autocratic government carries with it the suggestion of disloyalty to the principles upon which our own government is founded. Notwithstanding this difficulty and disadvantage a work such as the present one would be seriously defective were the attempt not made.

The best method of approach in considering this question is that of stating the advantages which experience would seem to indicate that an Autocracy possesses from the purely governmental standpoint, over its competitor type, Popular Government; and, in doing so, attempt to determine the extent to which these advantages are inherent in that type, and their absence in Popular Government is due to like inherent limitations, or merely to the failure to make the technical provisions necessary in order that they may find expression.

Approaching the question from this. standpoint, the leading merits of an Autocratic Government are: its unity of will, its simplicity of structure, its definiteness as regards the location and exercise of authority, and its consequent strength and effectiveness in operation. A government, no more than an individual, can function without arriving at definite decisions. These decisions can represent opportunist determinations in respect to particular matters as they arise or successive steps in the carrying out of a carefully thought-out, consistent policy. The first great problem in the organization of any government is the provision of means through which this general will of the State may be formulated and expressed. In an Autocracy the organ through which this is done is the supreme ruler, an organ possessing in the highest degree the qualities of unity and continuity. The fact that provision may be made in such a government for a popular assembly having for its function 
the making known of the wishes of the citizens of the State, does not represent an infraction of this principle. Legally final authority rests in the sovereign ruler, and the resolutions of the popular assembly have advisory force only. It is true that, under modern conditions the legally autocratic head of such a government is, as a matter of practical expediency, compelled to give great weight to such expressions of opinion, and often to subordinate his own desires to those thus expressed. In considering this apparent limitation upon his effective powers, it is important to note, however, that the supreme ruler, in consequence of his uniting in himself the functions of both will-determination and head of the administration, is in a position where he can play a powerful part in molding such opinion, in compelling the formal resolutions of the assembly to conform to his wishes, and, even, in many cases, of overriding it. The fact that he holds office by a permanency of tenure, while the composition of the assembly undergoes constant change, means, furthermore, that the ruler, when opposition is too strong, has only to bend himself temporarily to it, reverting to his own program at the earliest practicable moment. In this connection it is also to be noted that in all, or practically all, governments of this type the ruler has the power to dissolve the assembly which refuses to act in accord with his will and to summon a new assembly, a power which is constantly and effectively used by autocratic rulers to insure the carrying out of their will.

Finally, regard must be had to the fact that the powers possessed by a popular assembly in an Autocracy to make known the wishes of the people are radically different in kind, as well as in degree, from those possessed by a popular assembly in a Popular Government. In a Popular Government the popular assembly is the principal, and the chief 
executive, the agent. It is the popular assembly which formulates and expresses the will of the State. In a government of this type the will-formulating and expressing organ is thus one possessing neither unity nor continuity. It is composed of a large number of individuals and its composition is undergoing constant change. Here the exceedingly difficult problem is presented of evolving a collective will from a number of individual wills which represent many conflicting interests and aspirations and which rarely, if ever, are in complete accord. Even when such a collective will is finally evolved, no certainty exists that it will persist for any length of time.

It is evident from this comparison of the two types of government from the will-formulating or policy-determining standpoint that an Autocracy possesses an advantage which it is difficult, if not impossible, to secure in the case of a Popular Government. This advantage is especially apparent in the field of foreign relations; that is, in respect to the determination of the policy that will be assumed by the government in respect to its relations with other governments and the fundamental aims of the government in respect to its standing among the nations of the world. It is possible for a government to change its policy in respect to internal affairs from time to time without seriously jeopardizing its interests or those of its citizens. Indeed, with changing conditions, it may be highly desirable that it should do so. Its decisions in this field affect only itself and its citizens; or, at least, concern other governments and their citizens in but an indirect way. The foreign policy of a government, however, affects in a most direct way the interests of other governments. In an unavoidable sense governments are rivals, even though such rivalry may be of a friendly character. That government which can definitely 
formulate a policy in respect to the part that it desires to play in world affairs, and is in a position where it can consistently and persistently bend its efforts to its execution, has a great advantage over one which cannot do so. This advantage is clearly in evidence in the case of the two great Autocracies of the present time-Germany and Japan. No one can study the recent history of these two Autocracies without perceiving that each has worked out for itself a farreaching program of action in respect to the place that it desires to occupy among the nations of the world and has continuously devoted every effort to its accomplishment. In both cases this program has represented one vitally affecting the interests of other nations. The fact that, in the case of Germany, the attempt to carry out this program has resulted in a great league of nations to protect themselves against the carrying out of this program, does not in any way destroy the technical advantages of these two powers which have been pointed out. They merely evidence the fact that unwise use has been made of such advantage.

A second analogous, technical advantage of the autocratic type of government is the similar concentration of executive and administrative authority, not only in the hands of a single organ, but in that organ which is at once the one having legal responsibility for the formulation of policies and a continuous and independent tenure of office. The ruler of an Autocracy is unequivably the head of the administration. All administrative authority is vested in his hands. All officers of government, civil and military, are his agents. It results from this that administrative responsibility is definitely located and the line of authority is always clear. The administrative services are thus but parts of one highly integrated and correlated piece of administrative mechanism, 
and dangers of duplication or overlapping of organization or activities are reduced to a minimum. Such conflicts between services as do arise are easily adjusted by the superior organ of administration, of which they are parts.

In a Popular Government the source of administrative authority, as distinct from executive authority, is the popular assembly. It is the body which determines not only administrative policies, but the organs and procedure that shall be employed in their execution. Administrative officers are agents of the popular assembly, not of the chief executive. It thus results that the same disadvantages that a government of this type is under in respect to the determination of policies is found in the field of administration. The consequences resulting from these two systems of locating administrative authority can best be shown by comparing administrative conditions in Germany and the United States.

For years the German government has been held up as the leading example of governmental efficiency. This efficiency has very generally been ascribed to the special capacity of the German people for organization and the conduct of administrative affairs. This is a mistake. There is no evidence that the German people, as individuals, possess any such capacity superior to that of the American people. The real secret of the undoubted superior administrative efficiency of the German government over that of the United States lies in its autocratic character. If one seeks for the fundamental explanation of why, in the United States, there are found such evils as the pork barrel, log-rolling, special legislation, a system for the appropriation of funds making no approach to proper budgetary requirements, the spoils system, and a failure to develop a permanent, trained, technical personnel of administration; while, in Germany, these evils either do not exist at all, or are on a much smaller 
scale, the answer must be found in this fundamental difference between the governments of the two countries in respect to the location of administrative authority.

In the autocratic government of Germany administrative authority is located in an organ which is wholly outside of the field of influence of party politics and largely outside of the field of popular control. Every administrative officer from the monarch himself to the lowest petty clerk occupies this independent position. They are officers of the State, rather than servants of the people. As such their interest is in the State, rather than in that of any particular locality or class. Under such circumstances it is but natural that there should be developed a permanent trained bureaucracy for the conduct of affairs; that a consistent work program should be adopted; and that proper means for financing such work should be employed. All this is due to the fact that matters of administration are in the hands of agents who stand outside the field of party politics and popular pressure. It has been the good fortune of the author to have himself had a practical experience in the conduct of public affairs under a system of government such as this. For a matter of eight years he was one of the six heads of administrative departments of the government of Porto Rico. In this government all administrative powers were vested in a Governor and these six heads of departments, all of whom were appointed by the President of the United States. It resulted from this that Porto Rico had, from the administrative standpoint, an autocratic government. All administrative authority was vested in officers who were wholly outside the field of party politics in the Island. They did not owe their office to any political party, and were under no obligation to any section or class of the community. The result was that Porto Rico had an administration of its gov- 
ernmental affairs that was similar in all essential respects to that of Germany. It is the belief of the author that, in point of efficiency, the Island had an administration of affairs equal, if not superior, to that possessed by any state of the Union. This was due, not to any special competence or highmindedness of its officials, but to the conditions under which they had to perform their work. In Porto Rico, as in Germany, the secret of administrative efficiency is thus found in the independence of the administrative personnel, rather than in the personal qualities or attainments of the individuals constituting this personnel.

In the foregoing we have sought to set forth what are believed to be certain incontestable advantages of the autocratic type of government. There is, however, another side to the story. A government is not a mere piece of inanimate administrative machinery. It is an organization that must be operated by human beings, and in the interests of human beings, who themselves take an active part in its operation. Good government means something more than good administration. It means a government that in its practical operations has regard for the aspirations and welfare of the people subject to it, rather than the ambitions and interests of those in charge of the governmental machinery. A government thus has its moral as well as its material aspects.

In pointing out the merits of the autocratic type, it will be noted that we have at all times been careful to qualify these merits as technical ones. We are now going to see that, if such a government is considered from other than its purely technical aspect; that if we view it from its human or moral side, it presents elements of danger, if not positive defects.

In our consideration of the nature of the State it has been pointed out that the State may be deemed to have, from 
certain standpoints, a personality. As the possessor of personality, it may thus have interests distinct from, if not indeed antagonistic to, the interests of the individuals composing it. To cite but one common illustration: generally speaking it is for the interests of the State to raise the largest sum possible by way of taxation or otherwise, while it is often for the interest of the individual to keep his tax burdens at the lowest sum feasible. It is precisely in this lack of correspondence, if not positive antagonism, between the interests of the State and of the individual that lie the dangers inherent in the autocratic type of government. This danger is that the autocrat, holding his office as he does by no election by the people and legally not subject to their control, will look upon the interest of the State as his primary concern. He represents, indeed personifies, the State. If he exercises his powers to their full legal extent, he is, as Louis XIV expressed it, the State. In many cases the people themselves are looked upon by him almost as enemies of the State, or at least that portion which opposes his wishes is so regarded. The people are subjects not citizens.

This combination of the ruler representing the State qua State, and possessing legally unlimited powers is what gives to the autocratic government its special character. In practice it profoundly affects the manner in which the affairs of government are actually conducted, both in times of war and peace. It means that in peace the management of the affairs of government will be in the hands of a bureaucracy. The term bureaucracy is here used in a restricted or special sense. All governments have to make use of a systematically organized personnel for its administration. Such a personnel in a Popular Government, is, however, quite a different thing from the bureaucracy of an autocratic government. The personnel of the latter are, it is true, necessarily recruited 
from among the people. Once recruited, however, they constitute an officialdom with a tenure of office dependent upon the will of the ruler and largely independent even of that control which comes from the working of popular opinion. This profoundly affects their whole attitude towards the people in respect to the performance of their duties. It is this attitude which has given to the term bureaucracy its special significance as representing a narrow self-sufficient and arbitrary, if not actually oppressive, administration of affairs. In no place, so far as the author is aware, has this contrast between the two systems of administration been more effectively brought out than in the excellent study of European police systems made by Raymond B. Fosdick. In his introductory chapter on "The Purpose and Function of the Police," he said: ${ }^{1}$

To this divergence of problems (economic conditions, etc.) as well as to the distinct historic evolution through which each of the European nations has come, we must look for an explanation of the differences in power and authority conferred upon the police. In no two countries is the conception of the police in its relation to the public exactly the same. In Great Britain the police are the servants of the community. Their official existence would be impossible if their acts persistently ran counter to the expressed wishes of the people. They depend for their effectiveness upon public sanction. They are civil employees whose primary duty is the preservation of public security. . . In sharp contrast is the continental theory, which, evolved from the necessities of autocratic government, makes of the police force the strong arm of the ruling classes. The continental policeman is the servant of the crown or the higher authorities; the people have no share in his duties, nor indeed, any connection with them.

This same difference in respect to the status of officials

1 "European Police Systems," by Raymond B. Fosdick. Publications of the Bureau of Social Hygiene. The Century Co., New York, I9i6. 
and their attitude towards their duties and the public runs through all branches of civil administration in the two types of government. Apart from the fact that in an Autocracy a bureaucracy of this character may act with an arrogance and disregard of the wishes, or even rights, of the public is the further fact that, in it, the ruler has at his disposal a machine that he can use with tremendous force to mold public opinion to his way of thinking, or to coerce the people in the election of such representatives as the political system of the Autocracy may make provision for. That the power so possessed by the ruler in the leading Autocracy of Europe, Germany, is so used no one familiar with political conditions in that country will for a moment deny. Indeed, its use is not only acknowledged by Germany, but justified as a perfectly legitimate use by the ruler of his powers in order to advance the welfare of the State as he sees it.

It is, however, when we turn from a consideration of the influence of an Autocracy upon the conduct of governmental affairs in times of peace, to its influence upon the question of the State being plunged into war, and the conditions under which war shall be prosecuted and finally brought to a termination, that we have to do with the most serious danger that is inherent in an Autocracy. Militarism is the twin brother to bureaucracy. Or, to change the metaphor, bureaucracy and militarism constitute the two arms of the autocrat through which he is enabled to maintain himself and make his will prevail. There has been much confusion in the United States in respect to precisely what is meant when the term militarism is employed as a term of opprobrium. Militarism as so used is not synonymous with the maintenance of a large military establishment. The distinction between the two is precisely that which we have 
sought to draw between a bureaucracy in an Autocracy and an administrative personnel in a Popular Government. A military system in an Autocracy means the existence of a force of soldiers who are agents of the State, rather than guardians of the public. They constitute a military class accountable to no one but the autocratic ruler. The fact that the soldiers are drawn from the people, or that the system rests upon the principle of universal, compulsory military service, in no way lessens their character. The dis-tinction between them and the army of a Popular Government is essentially one of kind, not of size or degree.

If now the attempt is made to draw together these various lines that we have been considering it will be seen how inevitably they all tend to make of an Autocracy a restless and aggressive State, one which is a constant menace to its neighbors, and to the peace of the world. They reveal clearly the justification of the statement of President Wilson in taking the final step by which the United States entered the great war, that the world must be made safe for Democracy. In an Autocracy the State is not looked upon purely as a means brought into existence, or maintained by, the people composing it for the promotion and protection of their individual interests, as is the case in a Popular Government. It is deemed to have a life, interests and ambitions quite distinct from those of its constituent citizen members. This emphasized personality finds concrete expression in the person of an autocrat who believes that he has his authority by inherent right, and that he represents the State, rather than the people composing the State. It is inevitable that, under these circumstances, such an autocrat will deem it his primary obligation to seek to advance the interests and ambitions of the State as a State. Now the interests and ambitions of a State as a State are largely of a political and 
territorial character. They represent the desire to possess or control the largest possible portion of the territory of the globe and to exercise the largest possible influence in the determination of the destinies of its population. These ambitions can thus only be fully realized more or less at the expense, absolutely or relatively, of other States. If to this situation is joined the fact that the individual, having from the very nature of his status and tenure of office this ambition, also has supreme control over all the powers of the State, as represented by its civil and military forces, appreciation can be had of the almost inevitability that an autocratic government will be one seeking constantly to extend its influence and power in the world, and, as such, one constituting a permanent menace to the peace of the world. This, in fact, has been the actual experience in respect to Autocracies throughout the history of the world.

Internally an Autocracy has another consequence which is of the utmost importance. Due to the fact that the ruler and his agents, the bureaucracy and the military, represent the State rather than the citizens of the State, and that their primary interest is in the State, the government inevitably tends to become one in which great extension is given to the function of regulating the conduct of the people. This is a prime characteristic of all Autocracies. The emphasis tends to be placed on the general interests of the government and the people collectively, rather than on the interests of individuals. This finds expression in the trend towards state ownership and control of public utilities and all enterprises affected with a public interest and the regulation and control of individual conduct in the most diverse and far-reaching manner. This tendency to control individual freedom extends even to such matters as the expression of opinion through speech or the press, the right to 
effect organizations, the free play of political activities, etc. The principle is that the State comes first, that the interest of the individual must give way to its interest, and that the individual will realize his interest through the State. This explains the persistent effort on the part of the German government to check the social-democratic party. It seems a monstrous abuse of power for the government to use its power to defeat a political party. In Germany such action is deemed to be but a natural and legitimate use of the power of self-defense by the State. There is thus no place for the free play of political parties in an Autocracy such as exists in and constitutes a normal and essential feature of a Popular Government.

If now we attempt to sum up the long comparison we have made of these two types of government it will be found that application of the autocratic principle means : a government of the people by a bureaucracy, civil and military, deriving its powers not from the people or accountable to them, but from a ruler who in turn exercises his authority by what may be termed inherent right; a government in which the primary concern of the government is the promotion of the interests and ambitions of the State qua State; one in which consequently the interests and freedom of the individual must give. way to the interests of the State whenever the two are believed to be in conflict; one in which the emphasis is placed upon collective, rather than individual, welfare, and where the activities of the government, in the way of either the direct ownership and operation of interprises or the control and regulation of private enterprises, will be upon a large scale; where this power of the government over individual conduct will extend to all fields, religion, education, politics, expression of opinion through speech or the press, organization of associations of all kinds, 
etc. ; in a word, one of directed and regulated conduct in the internal field and aggressive action in the field of foreign politics.

The application of the principle of Popular Government, on the other hand, means a government of the people by a governing personnel deriving its powers from the people, and subject in the last analysis to their control; one in which the primary interest of the government is the promotion of the interests of the individual qua individual; where the government is looked upon merely as an agent of the people for promoting and protecting their interests and rights; where every emphasis is placed upon individual liberties and rights; where the government engages in activities and enforces rules governing individual conduct only where such action can be clearly demonstrated to be in the interests of the individual; one where it is of the essence of the system that the individual shall have all possible freedom of religion, thought, opinion, and right to express such opinion and, especially freedom to organize and take such action as is necessary to make known his opinions and wishes in the field of politics.

Broadly speaking then the distinguishing merits of the autocratic type lie in its mechanical aspects. They are summed up in the opinion so often expressed that the best government is an Absolutism, provided it is a benevolent Absolutism. There can be no question but that from the purely administrative standpoint the autocratic type possesses inherent advantages that can be secured with great difficulty by the popular government type. The advantages of the popular government type, on the other hand, are to be found chiefly in the moral field: the larger life and freedom given to the individua!; the greater probability that 
action will conform to his interests and wishes; the desire to maintain amicable relations with other powers.

Though, in the foregoing, stress has been laid upon the superiority of Popular Government over Autocracy from the moral or personal standpoint, it is of importance to note that it is by no means impossible for the former type of government to secure many of the purely technical advantages which are inherent in the latter, provided it will resolutely apply itself to the task. Efficient administration is not impossible in a Popular Government. It is merely more difficult to attain. To anticipate what will be more fully considered later on, the more essential steps that must be taken by a Popular Government to secure the efficiency of an Autocracy are: that the chief executive shall be given the definite status and powers of administrator-in-chief of the government; that, while the legislature need not surrender its function as the controlling organ, it shall look to the chief executive, acting as head of the administration, to formulate the annual financial and work program to be considered by it; that it will organize its several administrative services so that they will constitute an harmonious piece of mechanism; and, finally, that it will provide for an administrative personnel, having a permanency of tenure, selected and promoted strictly in accordance with merit and thus removed from sectional and party interests. The three great requisites of administrative efficiency in a Popular Government are, in other words, the adoption of a scientifically devised budget system, the establishment of an integrated administrative system, and the definite application of the merit system in respect to the selection and advancement of personnel. The great problem confronting a Popular Government is thus that of achieving administrative efficiency by providing for 
greater concentration and unity of responsibility in respect to the actual conduct of public affairs, while holding fast to its inestimable merits of placing primary emphasis upon the interests, rights and freedom of the individual.

It is important to realize also that Popular Government is in other respects a type of government that is much more difficult to organize and operate than that of an Autocracy. It requires a homogeneity, intelligence and toleration on the part of the people seeking to operate such a system that is not possessed by all people. In general these qualities have to be gradually acquired as the result of long experience. Especially is it difficult for a people suddenly to pass from an Autocracy to a Popular Government. The chaotic conditions following the Revolution of I9I I in China and that of I9' I in Russia are the direct outcome of the attempt to substitute at one stroke Popular Government for Autocracy. Similar conditions would undoubtedly prevail were the attempt made at once to confer full powers of self government upon the inhabitants of many of the colonies and dependencies of modern States. In respect to these the best thing that can be done is to keep firmly in mind the desirability of progressively conferring upon these peoples the right of self government as fast as circumstances permit, and of organizing and directing their political institutions with this deliberate policy in view.

Teridency for the Doctrine of Popular Sovereignty to Prevail.- If now we survey this subject as a whole, we find that the past century or century and a half have been marked by a contest between these two opposing principles. Though, as has been pointed out, victory has fallen, now to one principle, and now to the other, there can be no doubt that the general movement has been from Autocracy to Popular Government. If we are to judge at all from this 
cxperience, the conclusion must be reached that it is only a question of time when the latter doctrine will be universally held and the belief be general that supreme political authority should be deemed to rest with the people; that all officers of the government from the chief magistrate to the lowest civil servant or private in the ranks are but agents, employees of the sovereign people; that they have no authority but such as has been explicitly granted to them by such supreme source of authority; and that, as agents, they should be held to rigid accountability to their principal for the manner in which they discharge their duties.

The Struggle for Popular Government in Germany and Japan. - The governments of Germany and Japan constitute, as has been pointed out, the leading examples of the autocratic type of government at the present time. The citizens of those countries are, however, by no means unanimous in support of this type. In both, there has been for years a strong and growing demand that it be abolished and that the principle of popular sovereignty be substituted in its place. In form this movement has been one for the adoption of what is known as parliamentary responsibility; that is, that the officers of the government will be responsible to the lower branch of the legislature instead of to the Crown. As the members of the lower house are elected by the people, and parliamentary responsibility means that officers shall hold office only so long as their actions conform to the wishes of the majority of such members, this would mean that the source of authority would be transferred from the Crown to the people.

As this is being written word has come from Germany that this struggle is about to be successful. In a formal address to the Reichstag, the lower house of the German. legislature, on October 5, I918, the new chancellor, Prince 
Maximilian, on assuming office stated that the fundamental decision had been reached that thereafter the Chancellor and the other ministers of the Crown would be responsible to the Reichstag instead of to the Kaiser. He said that this decision had been reached by an agreement on the part of the federated governments and the leaders of the majority parties in the Reichstag. This intention to convert the government of Germany from an Autocracy to a Popular Government was still more emphatically expressed in the reply of the German Government given on October 20, I9I8, to the communication of the President of the United States in response to the request that the latter take steps for the granting of an armistice having in view the termination of the present great war. In this reply the German Government stated :

Hitherto the representation of the people in the German Empire has not been endowed with an influence on the formation of the Government. The constitution did not provide for a concurrence of the representation of the people in decisions on peace and war. These conditions have just now undergone a fundamental change. The new Government has been formed in complete accord with the wishes of the representation of the people, based on the equal, universal, secret, direct franchise. The leaders of the great parties of the Reichstag are members of this Government. In future no Government can take or continue in office without possessing the confidence of the majority of the Reichstag. The responsibilities of the Chancellor of the Empire to the representation of the people are being legally developed and safeguarded. The first act of the new Government has been to lay before the Reichstag a bill to alter the constitution of the Empire so that the consent of the representation of the people is required for decisions on war and peace. The permanence of the new system is, however, guaranteed not only by constitutional safeguards, but also by the unshakable determination of the German people whose vast majority stands behind these reforms and demands their energetic continuance. 
The foregoing represents merely a declaration of intention. Before it can be fully put into execution profound changes must be made, not only in the Imperial constitution but in the constitutions of Prussia and the other constituent states of the Empire. Though the sincerity of this declaration is questioned by many, and the fear expressed that it represents only a move to meet a temporary political exigency, it must nevertheless be taken as one of great import. Taken in connection with the strong demand for Responsible Government that had existed prior to the outbreak of the war, it can only mean that a long step has been made towards Popular Government, if that form of government has not been definitely established.

At almost the same time that this action was taken by Germany news has also come from Japan that the new ministry just established was one which had been constituted on the basis of representing the wishes of the lower house. If this practice is continued, here, too, the government is in the process of passing from the autocratic to the popular government type.

It will thus be seen that in the foregoing we have not been indulging in the mere exposition of the subtleties of political theory. On the contrary, we have not only been determining the essential difference that exists between different forms of government, but gaining an insight into the true character of the political movements which have played so important a rôle in the history of Europe during the nineteenth century, and which are still at work there and in the far East; - movements which have had as their great end the conversion of Autocracies from an Absolutism to a Constitutional Monarchy, and, in some cases, the more fundamental change of converting a government from an Autocracy to Popular Government. 


\section{CHAPTER IV}

THE TWO TYPES OF GOVERNMENT ACCORDING TO THE MANNER OF EXERCISE OF SOVEREIGNTY: ABSOLUTE AND CONSTITUTIONAL

In the preceding chapter we have seen that all governments may be primarily divided into three classes according to where the supreme authority, or sovereignty, is deemed to reside. Of these three classes only two, Autocracies and Popular Governments, are, however, at the present time of practical importance. We are now to see that each of these two types may be further subdivided into two classes according to the principle adopted in providing for the exercise of this sovereign authority.

Distinction Between Governments of Authority and Governments of Law.- If we analyze the problem that is presented to a people after it has decided upon the location of sovereignty, it will be found that the possessor of sovereignty has presented to it two alternative methods of action. It can exercise the supreme power vested in it arbitrarily; that is, without deeming itself to be bound by any general rules of conduct, or subject to any obligation to make its action uniform or consistent, action in each case being determined by its will at the time, or the seeming exigency of that particular case. Or, it can frame general rules by which it undertakes to be guided, these rules having for their purpose to ensure that the power will be exercised in a uniform and consistent manner and with such limita- 
tions in respect to procedure as will result in a just and equal treatment of all citizens in their relations to each other and to the government. According as one or the other of these two methods of exercising sovereignty is employed, a distinct type of government is established. This distinction is that between a Government of Authority and a Government of Law. Under the first the only sanction required for a governmental act is the will of the ruler. Under the second, every act must have the sanction of some law. This means that in the case of the second there must exist a great body of public law prescribing the form of governmental machinery, the jurisdiction and powers of its several organs and the methods of procedure to be employed by them.

Absolute and Limited Autocracies. - It needs but the statement of this distinction to make known that we have here to deal with a factor that has played an all-important part in the very progress of civilization itself, and that in it we have a prime characteristic differentiating the civilizations and political systems of the East and the West. Generally speaking, it may be said that, until the last half of the nineteenth century, the governments of the East have been governments of the first class - Governments of Authority. Sovereignty not. only resided in the hands of a supreme ruler, but was exercised by him in a purely personal, arbitrary manner. The governments resulting were pure Despotisms. Whether they were or were not benevolent Despotisms depended upon the accidental circumstances as to whether the ruler for the time being exercised his sovereign power for the purpose of promoting the welfare of his subjects or with a view solely to the gratification of his own caprices and ambitions. China, prior to the revolution of I9II, establishing the present republic, represents probably the best illustration of a government of this type. One 
should read such books as Bland and Backhouse's "Annals and Memoirs of the Court of Peking," and "China under the Empress Dowager," to see what a government of this kind is like. The monarch issued orders, termed mandates, prescribing governmental organization and procedure. These, however, were not laws in any proper jurisprudential sense. They were habitually disregarded; they lacked any adequate penalty or sanction; they did not bind the sovereign himself and were changed or departed from by him at his will. In substance and in form, they were for the most part mere exhortations such as a father might give to his child. China in fact may be deemed to have been at that time a country without law, public or private. Officers and magistrates, in discharging their duties and in rendering decisions for the settlement of private disputes, were guided primarily by what they thought the particular circumstances of each case demanded, rather than the enforcement of any general rules of conduct. The very conception of law was absent and indeed is at the present time largely lacking. Authority was enforced and justice administered precisely in the manner that the head of a family with us regulates and controls the conduct of his children. The people were exhorted to practice virtue and to refrain from evil. Rewards were promised for good conduct and punishment threatened for misconduct, but, only in the most loose and uncertain way were general rules with clearly prescribed sanctions laid down, or, if laid down, enforced with any uniformity or certainty.

We have described conditions in China prior to the revolution of I9I I with some degree of particularity, since doing so not only serves to make known in a concrete way the essential character of a Government of Authority, but lays the basis for a correct understanding of the real significance 
of a movement such as that of the revolution of I9II. To the world at large and, indeed, to no small extent, to the Chinese themselves, the significance of this revolution lay in the substitution of a republican for a monarchical form of government. This, however, represents a total misconception of the significance of that event. The really fundamental change there sought to be effected was that of the substitution of a Government of Law for one of Authority. That the Government of Law that it was sought to establish was of a republican rather than a monarchical form was, relatively speaking, a matter of secondary importance. ${ }^{1}$ What is true of China's revolution of I9I I is equally true of the revolution which gave to Japan her present form of government and of the abortive revolutions of Turkey and Persia. The change that took place in the government of Japan was no less momentous because she retained not only the monarchical but the autocratic form of government. The really important feature of that change was that she passed from a Government of Authority to one definitely of Law. In doing so, she inaugurated a movement which bids fair in time to bring the governments of the East into the same class in this respect as the governments of the West. ${ }^{1}$

Absolute and Limited Popular Governments.-Thus far we have considered this vital distinction between a Government of Authority and one of Law in respect to the autocratic type of government only. Though less clearly in evidence, it is of importance to note that the same distinction inheres in the popular type. Popular Government, if it is to prove workable at all, means in the last analysis a

1 The foregoing serves also to bring out the essential difference between revolutions having for their purpose the overthrow of authorities in the control of a government, and those having for their purpose the overthrow of the government itself, and the substitution in its place of a government of a different character. 
government by a majority. This means that a majority of the citizen electorate, no less than an individual autocrat, may, if it so minded, use its sovereign powers in a capricious, inconsistent and arbitrary manner; and, in doing so, have regard solely to its own wishes and interests, and be guilty of grave acts of oppression and injustice towards the minority. It, like the individual autocrat, has the choice of deciding whether it will regulate its acts, according to its wishes for the moment and the conditions surrounding each act to be performed, or will lay down general rules by which its action will be controlled and by which due safeguards will be set up for the protection and promotion of the interests of all citizens, rather than those of the majority who happen to be in authority. Nor is the danger slight that the former of these two methods will be employed. It has often been pointed out that no tyranny exceeds that of a majority. In the case of a majority there is present an apparent justification for its acts that does not exist in the case of an autocrat who represents the extreme case of a minority. When one considers the extent to which the populations of modern states are not homogeneous in respect to race or religion, have distinct or even opposing interests, such as exists in the agricultural as opposed to the industrial class, or the employing and the employee class, or occupying different sections of territory with their particular and special interests, we can appreciate how serious is the question here presented.

It is not our intention at this place to consider the general problem of Popular Government. It is only desired to point out that a Popular Government, no less than an Autocracy, must make provision for the conduct of all governmental operations strictly in accordance with law, if it is not to present all the evils of tyranny that have marked 
the absolute Autocracies or Despotisms of the past. That this is so is evidenced, not only by the conditions which prevailed in France following its Revolution of 1789 , but by conditions now obtaining in Russia.

Constitutional Government.-We have indicated that the distinction between a Government of Authority and one of Law constitutes one of the most fundamental distinctions in political science. It is-now our purpose to show that, in this distinction, we have the only really valid basis for distinguishing between what is popularly known as Constitutional Government and one not having that character.

The question as to what constitutes Constitutional Government has been a favorite one with writers in politics and jurisprudence. Notwithstanding the attention that has been given to the subject, it must be said that today, not only is there no general agreement regarding it, but that the ideas of individual writers are, upon close examination, found to be exceedingly vague. In so far as any test at all as to what constitutes Constitutional Government has been attempted to be set up, it has centered around the question of the guarantee of individual rights and liberties.

Probably the ablest spokesman of this school is President Wilson. In his book "Constitutional Government in the United States" he attempted to handle this specific question of what constitutes Constitutional Government. In his introductory chapter entitled "What is Constitutional Government?" he says:

"A Constitutional Government is one whose powers have been adapted to the interests of the people and to the maintenance of individual liberty. . . . Roughly speaking Constitutional Government may be said to have had its rise at Runnymeade when the barons of England exacted the Magna Charta of John." 
Though devoting a chapter to the subject this is the nearest that he got to stating what in his opinion was the real test of Constitutional Government. His reference to individual liberty, to the charter of rights exacted of King John, and his general consideration of the subject, show clearly, however, that with him the protection of individual liberty is the determining factor.

This attempt to make the guarantee of individual rights a test of Constitutional Government is a futile one. For example, it would be absurd to hold that England did not have a Constitutional Government. Yet that nation happens to be one in which there is not a vestige of legal guarantee of individual liberties and rights. The prime characteristic of the English government is the supremacy of parliament. There is no act which this body cannot legally authorize. It can by simple act order the property of $\mathrm{A}$ to be taken from him and given to $\mathrm{B}$, divorce the wife of $\mathrm{A}$ and order that she shall be deemed to be the wife of $B$, order the arrest of $A$ and his execution without trial and for an act which at the time it was committed was not only legal but praiseworthy. As its power has been wittily expressed, it can do anything but make a man a woman or a woman a man. It is true that there are certain charters and acts, such as the Magna Charta, Petition of Rights and Bill of Rights, in which the rights of individuals are deemed to be set forth with peculiar solemnity. Legally, however, these documents have no greater force than that of the most petty statute. Whether they are observed or not is purely a matter of expediency. The attempt to make the guarantee of individual rights a test of Constitutional Government, thus, leads either to the conclusion that all governments, except Absolutisms, are Constitutional Governments, or that the only government that is constitutional is one like that of the United States, where the 
field of individual liberties into which the government cannot enter is clearly defined, and means exist for insuring that these limitations upon the power of government will in fact be observed. In point of fact the important distinction which lies back of all this discussion as to what constitutes Constitutional Government, is the one which we have been considering, that, namely, between a Government of Authority and one of Law. Here is a distinction which is not only of the most vital importance, but one which can be clearly drawn, and which, when applied, serves to mark off governments of the world into two classes which are organically and fundamentally different from each other. Under this distinction, the goyernments of the United States, England, France, Germany, etc., properly fall into one class, while those of Oriental Despotisms fall into another. In Russia we have an example of a government which may be said to have not yet found itself. Though nominally falling in the first class, it in fact has not yet succeeded in emancipating itself wholly from methods of action characterizing the second class from which it has been slowly evolving. 


\section{CHAPTER V}

THE TWO TYPES OF POPULAR GOVERNMENT, DEMOCRACY AND REPRESENTATIVE GOVERNMENT

Sovereignty, we have seen, constitutes not only the prime characteristic of the State, but the factor in accordance with whose location and manner of exercise all governments can best be classified. Continuing to use this factor as the basis, or principle, of classification, it will be found that Popular Governments can be further classified in two distinct types according to the decision reached in respect to the body or organ to which will be entrusted the actual exercise of the sovereign powers which reside in the people.

Having decided to create a government of a popular type, a people has presented to it the alternative of, either itself exercising its sovereign powers, or of entrusting their exercise to an agent or agents to be selected, instructed and controlled by it. According as it adopts one or the other of these policies, it brings into existence distinct types of Popular Government to which have been given the names of Democracy and Representative Government.

Definition of Democracy.- The word "Democracy" is unfortunately used in popular discussion, and indeed in much political literature, in two quite different senses: as designating a society or community in which class distinctions are absent or relatively unimportant, and as designating a distinct form of government. It is in the latter, or technical, sense that the term is here employed. A Democracy, to repeat more fully what has already been said, is 
that form of Popular Government which results where the voters of a State, acting collectively as an electorate, themselves, directly administer the affairs of government. By this is not meant that they perform the physical work of building and repairing roads, operating schools, administering justice in the courts, etc., but that they, as an electorate, attempt directly to determine all matters of policy, reach all important decisions, and select, direct and supervise the officers under whose immediate direction the actual work of government is performed; that they, in a word, directly assume the functions of a legislature and a board of directors in respect to the conduct of governmental affairs. Under this form of government the electorate occupies, in a Popular Government, precisely the position of the monarch in an Absolutism. It is at once the custodian of legal sovereignty and the directing head for its actual exercise.

Inherent Limitations of Democracies.- It is hardly necessary to point out that a Democracy may be said to correspond to the highest ideal of Popular Government. It represents a form of government in which sovereignty not only resides in the people, but is actually exercised by them. Notwithstanding this theoretical superiority, Democracy, as a form of government, presents certain practical limitations that make it difficult of application, except under unusual and specially favorable conditions. These limitations consist: in the difficulty in securing prompt and decisive action on the part of a numerous body; in the delay and trouble involved in getting this body together; in the impossibility of this body meeting the demands upon it, where the amount of work to be done is at all large; and in the fact that such a body neither has the knowledge nor the training fitting it to handle matters of a special or technical character, and is necessarily so constituted that it 
can devote but a part of its energies to the work to be done.

These disadvantages are technical and apparent. There is, however, another which, though more subtile, is none the less of importance. This consists in the fact that, in a Democracy, the actual conduct of governmental affairs is in the hands of those possessed of absolutely unlimited powers. All the dangers which we have described as inhering in Popular Government, arising from the fact that that form of government means government by a majority, are thus present in an acute form in a Democracy. At its best a Democracy may represent the ideal form of government. At its worst, it may be little better than mob rule.

Due to these limitations and dangers, Democracy, as a form of government, has played but little part in the history of government. The only instances where it has achieved a fair degree of success are those furnished by certain of the States in ancient Greece, by the smaller forest cantons of Switzerland, and the towns of New England in our own country. In respect to all of these, it will be noted that, not only were all of the special conditions which we have mentioned as being necessary for the successful operation of a Democracy present, but that, if we except the Grecian Democracies, which were little more than City States, the attempt was not made to apply this type to the entire government of a State but only to certain of its minor sublivisions. Furthermore it is to be also noted that, even in these cases, the experiment has been abandoned or is in process of abandonment. The Greek Democracies are no more, and the history of the Swiss cantons and the New England towns during recent years shows that they are steadily abandoning their democratic principles, and passing to the representative or mixed democratic-representative type of government. For this change, 
the great increase in the demands made upon the government of all communities, which has been a characteristic feature of modern political life, is chiefly responsible.

If we attempt now to sum up the result of our critical consideration of Democracy as a form of government, we may say that, notwithstanding the attractiveness of the idea underlying it, it is a form of government which, due to inherent limitations, can be applied with success only under certain special conditions. Whenever the territory is large, the population numerous, the interests varied, the functions of government complicated, or the people not of a high degree of intelligence and exceptional political capacity, a pure Democracy may be deemed to be unworkable. Under modern conditions at least Democracy may thus be deemed to be a form of government that will find a place only for the administration of the purely local affairs of specially favored communities. Even here it is doubtful whether the results secured will be superior to those that could be obtained where use is made of the representative form of government.

Representative Government.- The foregoing rather lengthy consideration of the limitations of Democracy has been essential in order that we might see clearly the reasons why, as a matter of fact, it has given way to the alternative form of Popular Government, known as Representative Government.

A Representative Government, we have seen, is that form of government which results where a legally sovereign electorate, instead of itself attempting to act as the directing head of the machinery of government, brings into existence an organ or organs to represent and act for it in this capacity. The discovery, or rather the application, of this principle of representation to the management of the 


\section{4 THE GOVERNMENT OF MODERN STATES}

affairs of the State is rightly deemed to mark one of the greatest advances that has been made in all time in the art of government. Without it, as will shortly appear, the present great extension of Popular Government would have been impossible, and the doctrine of popular sovereignty would probably have remained but the dream of philosophers, incapable of realization in practice. It was in the perfection of the means through which this principle could be practically applied, as much as in her insistence upon the recognition of individual liberties, and the provision of effective means for their protection, that England made her great contribution to the principles and art of government.

In studying this form of government, it is well to consider it from two points of view: as a device by which the principles of Popular Government can be applied to large populations and extensive territories; and as involving a principle of government essentially different from that underlying Democracy.

As a device, it is evident that it meets most, if not all, of the technical limitations which we have seen prevent the successful operation of a Democracy, except in the case of small communities with relatively simple governmental problems to be met. Once adopt the principle of a small number of officials being selected by a large body to act for it, and all barriers which size of country or amount of population had seemed to oppose to the spread of Popular Government at once disappear.

Representative Government, however, differs from a Democracy in a far more important respect than is represented by this mechanical feature. Fundamentally it is based on the principle that, though sovereign authority resides in the people, the latter are incompetent to exercise 
it, except in the most general way. Representative Government draws a clear distinction between the possession of sovereignty and its exercise. The former, it, in common with Democracy, claims resides in the people; the latter it maintains should reside in officers specially selected on account of their qualifications for that work. Essentially the advocates of Representative Government take the position that the conduct of the affairs of government require a high degree of education, special knowledge and skill, and that it should be consequently undertaken by officers specially selected for that work.

It is impossible to lay too great stress upon these two fundamentally different points of view. Advocates of Democracy say that the people are not only competent, but can be trusted to exercise a wise and just discretion in making political determinations. Advocates of Representative Government deny this. They maintain that, under modern conditions at least, decisions in respect to matters of legislation and administration, if they are to be wise, must rest upon a special study of conditions that is possible only by a relatively small body of officers specializing on this work. Their position, in a word, is that the co Iduct of governmental affairs is a special work requiring special abilitics, training and knowledge, and therefore one to be performed by a special body having these special qualifications.

This, however, is not their whole case. They lay great stress upon the dangers, which we have seen inhere more markedly in a Democracy than in other forms of Popular Government, that a dominant majority will use its power in an arbitrary, tyrannical, capricious and oppressive manner. A Democracy acts with full powers; there is no check upon its action; there is no authority to which it is 
responsible, or by which it can be held to account. Political authorities in a Representative Government have the scope of their functions and powers defined, and the manner of their exercise determined. They work under a sense of responsibility and accountability. Occupying, as they do, a special position, they can view the problems presented and the results likely to flow from particular lines of action, in a more detached manner.

Mixed or Democratic-Representative Government.In the foregoing we have defined and described what may be termed a pure Democracy and a pure Representative Government. In practice a people may adopt a system of government lying midway between these two systems. It may thus decide to vest the exercise of certain of its powers in representative organs and retain the exercise of the remainder in its own hands. When it decides to do this, it brings into existence a government of a mixed type to which we may give the designation Democratic-Representative.

The Government of England the Purest Example of a Representative Government.- Of all governments that of England represents the purest type of Representative Government that has ever been established. The people of England have vested the entire exercise of their sovereign powers in a single agency, Parliament. That agency represents them in every capacity. The people themselves perform no political act but that of selecting the members of this body. They do not even attempt, through their political parties, or otherwise, formally to instruct their agent as to what policies it shall adopt or what measures it shall undertake. Nor have they retained in their hands the constituent; that is, the constitution determining power as distinguished from the legislative power. The grant of 
authority to Parliament is, in a word, plenary. The government resulting may thus be said to be as pure a type of Representative Government as it is possible to conceive.

The Government of the United States a Representative Government in Principle.- The distinction between a Democracy and a Representative Government was clearly understood by the framers of our constitution. Due to their appreciation of the dangers which they believed to be inherent in the former type, rather than to the technical difficulties in the way of making that type work successfully, they took every possible precaution to insure that the government they were creating should be a Representative Government, and not a Democracy. They were as anxious to avoid the dangers of a Democracy as they were those of an Autocracy. To them Democracy meant mob rule, and was so denominated in their political discussions. That this is so is clearly shown from the care taken by Madison to point out in the Federalist Papers the distinction between the two types of government, and the consequences to be expected in the practical working of the two types. He there wrote:

From this view of the subject it may be concluded that a pure Democracy, by which I mean a sóciety consisting of a small number of citizens, who assemble and administer the government in person, can admit of no cure for the mischief of a faction (party strife). A common passion or interest will in almost every case, be felt by a majority of the whole; and communication and concert result from the form of government itself; and there is nothing to check the inducements to sacrifice the weaker party or an obnoxious individual. Hence it is that such Democracies have ever been spectacles of turbulence and contention; have ever been found incompatible with personal security or the rights of property; and have in general been as short in their lives as they have been violent in their deaths. 
Theoretic politicians, who have patronized this species of government, have erroneously supposed that by reducing mankind to a perfect equality in their political rights, they would at the same time be perfectly equalized and assimilated in their possessions, their opinions and their positions. A Republic, by which I mean a government in which the scheme of representation takes place, opens a different prospect and promises the cure for which we are seeking. ...

The two great points of difference between a Democracy and a Republic are: first, the delegation of the government in the latter to a small number of citizens elected by the rest; secondly, the greater number of citizens and greater sphere of country over which the latter may extend. ${ }^{1}$

Not only did the framers of our corstitution desire to ensure that the national government they were bringing into existence should be of this character, but that the governments of the individual states should be the same. It is for this reason that, notwithstanding the strong feeling that the power of the central government should be restricted within the narrowest limits compatible with the formation of a strong and permanent union and that, as far as possible, each state should be left the maximum of freedom in the management of its own political affairs, they placed in the federal constitution the provision that "the United States shall guarantee to every state in this Union a republican form of government. ${ }^{2}$

1 The Federalist, No. Io.

2 Art. IV, Sec. 4. The expression "republican form of government" is here used to indicate that type of Representative Government where the chief magistrate is elected by the people. The provision thus equally precludes the establishment by a state of either a Monarchy or a Democracy. This provision not only imposed upon the states the obligation to adopt this form of government, but likewise placed the obligation upon the national government to see that this was done. On one notable occasion, that of Dorr's Rebellion in Rhode Island, the national government was forced to intervene to enforce this provision. 


\section{The Contest Between the Principles of Democracy} and Representative Government in the United States.Though no one can question that the government of the United States is properly to be designated a Representative Government, it is important to note that, neither in its legal constitution, nor in its practical operation, is it so pure a type as that of England. In the first place the people have retained to themselves the final decision in respect to the making of changes in the government set up by them. Secondly, they have built up a system of party organizations through which they seek by means of the adoption of programs to make known their wishes in respect to the policies that shall be adopted and put into effect by their representatives. Finally, during recent years there has developed a strong movement for the adoption of the political devices known as the "Initiative," "Referendum" and "Recall," through which the people may themselves directly make political determinations.

If one surveys the history of politics in the United States since the adoption of the constitution, it will, in fact, be found that one of its most fundamental features has been the persistent contest between the democratic and representative principles of government. The political revolt which led to the election of Jackson as President in I824 was essentially one having for its purpose the strengthening of the direct influence of the people on the conduct of government. The accomplishment of this end they saw in the requirement that all administrative officers of any importance should hold office as the result of direct election by the people. In practice this system utterly failed to accomplish its purpose. The people found it an impossible task to select competent officials for a large number of different positions, many of them of a purely technical character. 
Control instead of being strengthened was weakened. As a result there has been in recent years a strong reaction against the system. This finds expression in the demand for the adoption of what is known as the "Short Ballot," that is, the adoption of the principle that only the relatively few officials having distinctly political, i.e., policy-determining, functions, as distinguished from purely ministerial, or administrative, duties, shall be elected by the people, and that all other administrative officials shall be appointed by them. This movement has the support of almost all students of politics and is slowly advancing.

The latest phase of the contest between the principles of Democracy and Representative Government is the movement already mentioned for the introduction into our political system of the devices known as the Initiative, Referendum and Recall. Certain progress has been made in this direction, but it is impossible at this time to determine the extent to which these devices will become integral parts of our political machinery. Manifestly it would be out of place to attempt here to consider the merits and demerits of these proposals. They have been mentioned, however, as illustrating excellently how impossible it is to judge political proposals unless one has a clear conception of the fundamental principles involved. 


\section{PART III}

\section{THE ESTABLISHMENT OF GOVERNMENTS}





\section{CHAPTER VI}

\section{THE FORMULATION OF CONSTITUTIONS}

In the preceding pages we have seen that a people desiring to constitute itself a State has to make certain fundamental decisions before it can proceed to the work of creating a government through which its powers as a State shall be exercised, and that, according as one or another decision is reached, a distinct type of government results. With these questions answered there is then presented the problem of making provision for the actual conduct of the affairs of the State; in other words, the establishment of a government.

Governments Established Through the Formulation of Constitutions.- The means employed by communities which have decided to constitute themselves as States in organizing a government for the conduct of their State, or political affairs consists in the formulation of a definite set of principles or provisions embodying, or setting forth, the fundamental features of the government to be created. These principles or provisions, as thus formulated, are collectively known as the constitution of the State. In describing this act by which a form of government is determined use has been made of the term "formulation" instead of "adoption," since one of the most important features of any political system consists in the fact that it is undergoing constant change. This change, as we shall shortly see, takes place in a number of ways. It is sufficient here, however, to point out that the problem of the 
formulation of a constitution has two distinct phases; that of the adoption of a constitution, in the first place; and that of its subsequent modification, as changes in political ideas or conditions take place. Each of these phases has its own particular problems which will have to be separately considered.

Written and Unwritten Constitutions.-In all cases, except that of England, these fundamental provisions of the governmental system are set forth in a formal document or documents which, as a document, is styled the constitution. For reasons which will hereafter appear, England has never reduced her basic political provisions to formal written form. These principles, however, are none the less definitely determined, and England, for this reason, is said to have an unwritten, as opposed to a written, constitution. In the past great stress was laid upon this difference in practice of England and other countries. That important consequences flow from it cannot be doubted. It is now recognized, however, that, in the case of all countries, there are many fundamental political provisions which are not set forth in their formal constitutions but which none the less must be deemed to be of a constitutional character. Of no country is this more true than of the United States, which, of all countries, is supposed to have a peculiarly inflexible constitution. Thus, to illustrate, our constitution makes no reference to such important political institutions as the President's Cabinet, the Congressional Caucus, or Political Parties. No one can question, however, that these institutions constitute as integral parts of our political machinery as almost any formally provided for in the written constitution. The difference between written and unwritten constitutions is thus one of degree as well as kind. The most important fact, from the stand- 
point of the study of government, resulting from this is that only a very imperfect idea can be obtained of the governmental system of a country, as it actually exists and functions, by a mere study of its written constitution. The constitution considered alone is a dead, inert thing. It is this which makes the study of government, seemingly an easy one, in fact one of great difficulty, requiring in high degree the exercise of the inquisitive and analytical faculties.

Methods of Establishing Constitutions.-We have pointed out that the task of formulating a constitution has two distinct phases; that of its adoption in the first instance; and that of its subsequent modification, and that each of these phases presents special questions or problems requiring separate consideration.

If we analyze the problem of the adoption of a constitution in the light of history it will be found that modern States have acquired their constitutions in four different ways: ( I) by grant; (2) by deliberate creation; (3) by a process of gradual evolution; and (4) by revolution.

Establishment of Constitutions by Grant.- Historically, most modern States began their careers as, or speedily became, in effect, Autocracies. The adoption of systems under which the governmental organization and the exercise of governmental powers were carefully-described and defined in written constitutions is a distinctly modern phenomenon. It dates only from the end of the Eighteenth and the beginning of the Nineteenth Centuries. In the development of their constitutional systems most existing States have therefore had to start from the point where all governmental authority was vested in the hands of their rulers and was defined only in a most general way. Under these conditions, the first and simplest method by which a 


\section{THE GOVERNMENT OF MODERN STATES}

State may become endowed with a constitution is that whereby the ruler decides that the interests of the State and of its citizens require that the organization and powers of the government and its several agencies shall be carefully set forth in a formal document. In practically all cases this has meant that the ruler has consented, in fact, if not in theory, to surrender his position as an autocrat, and has undertaken to exercise his powers in accordance with certain principles and through certain agencies and procedure. This decision he has put into execution through the promulgation of a document or constitution embodying these principles and provisions by which he undertakes to be bound in the future exercise of his political powers. A constitution so established is said to be one by grant or to be octroyed.

It is immaterial, from the standpoint of political science, whether the ruler's motive in doing this is a belief that the powers of government and the manner of their exercise should be defined in a document of a formal, legal character, or is a desire to avoid the consequences that might follow should he refuse to do so. The important thing is that this act is his act. When a government is established in this way the sovereign ruler acts as does a constitutional convention. He frames the constitution that shall provide for the new form of government, adopts it and promulgates it. The actual drafting of the constitution may be performed by some other body, but such other body acts merely as his agent and the work must be adopted by him as his own. Legally the act is his and his alone and it is his approval that gives it validity.

Important consequences flow from this. Of these the most important is that the ruler in promulgating the constitution does not thereby divest himself of his sovereign 
power. Sovereignty continues to reside in him. He merely undertakes to exercise this power in the manner set forth in the constitution as promulgated by him. Legally, he can, at any time, modify, suspend or wholly abolish it. Actually, however, the attempt to do so may provoke such discontent on the part of his subjects that he will only make the attempt under most unusual circumstances.

In point of fact, most constitutions owing their origin to this method of establishment have been granted by rulers as the consequence of demands on the part of their subjects which they have found it impossible, or impracticable, to resist. They have been forced from rulers as the direct consequence of threatened revolutions.

Of modern States the most important that have received their constitutions in this way are Japan, Prussia, Austria, and indeed most of the European Monarchies with the exception of Belgium. The governments of these states are thus still Autocracies, though of the limited instead of the absolute type.

\section{Establishment of Constitutions by Deliberate Crea-} tion.- A second method by which a constitution may be established is that where it is formulated and adopted by a people at the time that it erects itself into a State, or immediately following that act. A constitution so adopted may be said to be adopted by deliberate creation. It is hardly necessary to point out that opportunities for the establishment of States and the adoption of a constitution in this way are comparatively rare. It can only occur where a community, the members of which have already had a political experience, emigrates to a territory the inhabitants of which, if any, have no political organization, the authority of which the emigrants are willing to accept. It is indeed doubtful whether any instance of the creation of a 
sovereign State in this way can be cited, though a close approach to it has been made in the organization of governments by the colonists who have gone out from England for the purpose of establishing settlements beyond the seas. In all, or practically all, of these cases the persons participating in the enterprise have, however, continued to recognize the political authority of the mother country. Though their action has been analogous to that of the creation by deliberate act of a constitution for an independent State, the act itself had to do only with the establishment of a government for the conduct of local affairs.

At the present time the most interesting example of the adoption of a constitution by deliberate creation would be afforded should the Poles, Czecho-Slovaks and Jugo-Slavs, as the result of the present war, be recognized as independent States and be permitted to organize for themselves their own forms of government.

Establishment of Constitutions by a Process of Gradual Evolution.-A third method by which a constitution may come into existence is that whereby a State secures its form of government as the result of slowly working evolutionary changes. This takes place where a State starts with an autocratic government, and gradually secures a government in which political authority is deemed to reside in the hands of the people. This transfer of the seat of sovereignty usually takes place in this way. Originally both the possession and exercise of sovereignty rests in the hands of the ruler. Gradually, as a matter of fact, though not of law, the power of determining how this sovereign power shall be exercised passes from the hands of the ruler to persons selected in some way by, or at least claiming to represent, the people. In time what was at first merely a de facto power comes to be looked upon as a de jure 
power. Long acquiescence in the determinations of these representatives has deprivesd the ruler of any real power to act counter to them and he in turn accepts the new principle of sovereignty as the de jure as well as the de facto condition of affairs.

The leading, if not the only, example of where a Representative Government has come into existence through this method is furnished by Great Britain. Certain acts, such as that of the election of William of Orange as King by the Parliament in I688, may constitute decisive steps in this evolution; but the process itself has been one of gradual change in the attitude of the people towards their government and of acquiescence and action on the part of their rulers in this change. In the case of Great Britain, not only has this change been a gradual one, but an almost unconscious one. So much so has this been the case that the change has been one primarily in the spirit of political practice rather than in the form of action. The result is a political system in which the government as a matter of form and mode of procedure is still of an autocratic character, though as a matter of fact the government in its practical workings is as thoroughly a Representative Government as any existing in the world. It is due to this fact that it is so difficult for the foreigner, and indeed for the Englishman himself, to describe or understand the English system of government. Only as one ignores the form and attends to the actual workings of this government can its essential character be determined. It is for this reason also that we are confronted with the unique phenomenon of a State having a definite form of Representative Government without possessing any written or formulated body of supreme law corresponding to the constitutional documents of other countries. 
It is quite possible that by an analogous gradual change in thought and action States, such as members of the German Empire, now having an autocratic government but possessing constitutions representing declarations by the sovereign ruler of the manner in which they will exercise their sovereign powers may in turn become States with a Representative Government and the constitutions be deemed to rest upon the authority of the people, though originally acquired by way of grant from a sovereign ruler.

It should also be noted that a Representative Government may come into existence as the result of evolution from a Democracy. This would occur where the people of a Democracy find that it is impracticable for them to manage their political affairs directly, and decide that it is preferable to entrust such management more and more to agents selected by them to represent them in this capacity. This is what has taken place in recent years in those territorial subdivisions of the Swiss Republic and the United States, the forest cantons of the former and the towns of New England of the latter, which attempted at the start to have their political authority exercised directly by their electorates. Steadily this democratic practice has been departed from and the governments of these communities have assumed more and more a representative character.

Establishment of Constitutions by Revolution.-A final, and much more usual, method by which a constitutional system is established is that by revolution. This occurs when a people living under an Autocracy becomes dissatisfied with that form of government and decicles, notwithstanding the opposition of its ruler, to establish in its place a government resting upon the principles of popular sovereignty and Representative Government. This is the method through which were established the Representative 
Governments of the First French Republic, our own Republic, the present Republic of China, and more recently the Soviet Government in Russia.

Dual Character of Revolutions: A Revolt Against Existing Governmental Conditions and a Movement to Establish a New Type of Government.-In studying these movements whereby a change in the form of government is forcibly brought about it is of interest to note that revolutions present two distinct phases or aspects. They are an armed protest against existing misgovernment or oppression by the governing authorities and an assertion that the government, purely as a matter of political theory, should rest upon another principle. Neither one of these motives alone seems to be sufficiently powerful to bring about a successful revolt. History furnishes few. if any instances of where a people, having little to complain of in the way of misgovernment or oppression by their political authorities, have overthrown such government simply because they had become persuaded that their government, as a matter of political theory, should rest upon a different principle as regards the location of sovereignty. On the other hand it is equally noteworthy that it is exceedingly difficult to rouse a people to revolt against an existing government, once firmly established, no matter what the degree of misgovernment and oppression to which they may be subjected, until they have been persuaded that some great principle is at stake. The need in other words seems to exist that a revolutionary movement should be justified in theory as well as in fact. It has always been difficult on the part of many to understand the significance that historians have attached to the preachings of Voltaire, Rousseau and other writers of the Eighteenth Century in bringing about the French Revolution. The explanation of 
this is found in this characteristic of the people which we are considering. These writers furnished the philosophical basis for the revolution. Not until a justification for their action, as a matter of theory or principle, was established, could the people be brought to the point of the united action required for success.

In the case of the establishment of our own government, we have evidence of this need for a philosophical justification of the act of revolt. This justification was formally expressed in our Declaration of Independence. Whatever may have been the conditions causing the people to take action, the Rebellion itself was made to establish certain fundamental principles in which the people at that time firmly believed.

If we turn to more recent happenings, the establishment of a Republic in China, and the deposition of the Czar in Russia, we find that, not until the people of those countries, or those portions of the people capable of taking intelligent action, had been imbued with a belief in the doctrine that a government should rest upon the principle of popular sovereignty, instead of that of autocracy, was it possible for a successful revolt to be made against the long standing misrule and oppression of their autocratic rulers.

Difficulties in Establishing a Government by Revolution.- Of all methods of establishing a constitution, that by means of a revolution is much the most difficult, and resort to it is justified only when all other means have failed. Rarely is success achieved except after years of turmoil and bloodshed. The French Revolution led to years of fighting before stable political conditions were finally achieved. In one sense it might almost be said that the final end sought was not attained until the establishment of the present form of government in IS7I. In the case of 
our own revolution we had to go through the so-called critical period of thirteen years from 1776 to 1789 before a definitive constitution was adopted. The revolution of I9I I, in China, by which the old Manchu Dynasty was overthrown, has as yet failed to give to that country a permanent constitution. The revolutions in Turkey and Persia a few years ago proved to be abortive and the final form of government that those countries will have is still in doubt. The revolution in Russia in I9I7 has been productive of extreme disorder, and it is impossible to foresee the outcome.

The situation confronting a population which has succeeded in overthrowing the established government is as follows. It finds itself in the first place owing allegiance to a government which can hardly be otherwise than a temporary makeshift, one hastily organized for the purpose of conducting a revolutionary movement rather than for providing a permanent constitutional system. In the second place this government is strictly speaking an illegal one, or at least one which was illegal in its inception and, even after all resistance against it has ceased, probably still lacks that affirmative action on the part of the people that will give it full legality in accordance with the doctrine of popular sovereignty. The government in existence is essentially one known as a Provisional Government, a de facto but hardly as yet a de jure government. The problem is to convert this provisional, imperfect, de facto government into a permanent, carefully elaborated, de jure government, or rather to supplant it by one having the latter characteristics.

k In solving this problem the Provisional Government has several lines of conduct open to it. It can, in the first place, assume that it has full power to act as the representative of the people in respect to the work of both drafting and adopt- 
ing a permanent constitution and, if the people acquiesce in this assumption, it must be presumed that they in effect have the necessary public sanction for the exercise of this power. This is the position that was taken by the Constituent Assembly which was brought into existence to represent France in the ratification of the treaty bringing to a conclusion the Franco-Prussiain War of I870-7I. This Assembly, though elected nominally only for the purpose of settling the terms of peace with Prussiá, in fact found itself on the conclusion of the treaty the only general political authority of the land. It was quite proper for it therefore to undertake the work of a Provisional Government. It, however, went much further than this. In addition to acting as a de facto or Provisional Government, the Assembly took to itself the function of a.constituent assembly or constitutional convention and proceeded, after an interval of several years, to formulate and enact a series of fundamental laws, which, with certain amendments, constitute the existing constitution of the present French Republic. It is a matter of no little interest to note, therefore, that, though France is now undoubtedly in possession of a full Representative Government, the constitution providing for this government was neither drafted nor adopted by a body directly authorized by the people to undertake this work, nor was it ever referred to the people or approved by them in any way other than by tacit acquiescence in an accomplished fact. It should be noted, however, that the body performing this work was not a self constituted body but was composed of members duly elected by the people though not elected for the express purpose of performing this work.

A second line of procedure is for the Provisional Government frankly to recognize both its provisional character and 
the limited scope of its authority and, proceeding on this basis, to take the necessary steps by which a permanent government may be established by deliberate affirmative act of the people. If it adopts this policy it can do one of three things: (I) it can itself draft a constitution and submit it to the people for adoption; or (2) it can provide for the assembling of a special body the members of which are selected by the people in some way for the drafting and adoption of a constitution; or (3) it can provide for a body of this character having the function simply of drafting a constitution which shall be submitted to the people for approval. It need hardly be pointed out that the latter method constitutes the one most nearly conforming to the principle of popular sovereignty. It is therefore the one that should be adopted unless the existence of bitter divisions among the people regarding the character of government to be established are such as to render it likely that a resort to this method would invite further dissensions and possible disaster to the whole undertaking.

In the case of our own revolt from England, provision was made for the assembling of a special convention for the framing or drafting of a constitution and that convention, after completing its draft, provided that it should go into effect as soon as it had been ratified, that is, adopted, by nine states acting through state conventions assembled for that purpose.

A nice question is presented as to whether the convention framing our constitution was not a revolutionary body since no provision was made for any such body by the existing constitution, the Articles of Confederation, that document making no provision by which constitutional changes might be effected.

In the foregoing, we may seem to have gone out of our 
way in discussing the character of political revolutions. We have felt justified in doing so both on account of the great importance of the subject at the present time and the extreme difficulty that exists in making students appreciate the importance that matters of pure political theory play in determining the course of historical events and the character of governments enjoyed by States. Next to the present world war itself, the greatest political movement of modern times has been the widespread revolts in various quarters of the globe, in Russia, China, Turkey, Persia, and elsewhere, for the establishment of new forms of government. If we are to understand this movement we must see clearly that these revolutions are essentially. ones having as their issues great political principles rather than a mere protest against governmental conditions and practices. 


\section{CHAPTER VII}

\section{THE MODIFICATION OF CONSTITUTIONS}

Turning from a consideration of the manner in which constitutions are adopted to that of the manner in which they are, or may be, modified, we have to deal with an entirely new set of problems. Though supreme importance attaches to the act of adopting a constitution, in the first instance, and the problem is one which has yet to be met by many politically backward peoples, it is not one of practical importance to most nations.

All western nations at least, with possibly one or two exceptions, have firmly established constitutional systems. The problem of constitutional development is thus that of the modification of these systems rather than that of creating new constitutions out of hand.

This problem, moreover, is one which is always with us. Particularly is this true of the United States at the present time. After years of unquestioned adherence to certain fundamental principles lying at the basis of both our federal and our state constitutions, public opinion has begun to question whether they have the virtue or validity which has been so universally attributed to them in the past. There is scarcely a state among our forty-eight commonwealths in which important constitutional changes are not now being seriously urged. The problem of the modification of constitutions is thus a very live one.

The Question of Policy in Respect to the Ease with which Constitutions May Be Modified.- If an analysis 
of this problem of constitution modification is made it will be found that it involves two sets of considerations: (I) the policy that should be adopted in respect to the facilitation or the restriction of the effecting of modifications in a constitution once adopted; and (2) the procedure that should be provided by which this policy is to be carried into effect. The first is one of principle; the latter one of means. Manifestly no intelligent action can be taken in reference to the second until a decision has been reached regarding the first. Before taking up the various means by which constitutional changes may be effected, as illustrated in the political system of our own and foreign countries, we shall therefore seek to point out the considerations that have to be borne in mind in formulating a policy regarding the amendability at all of constitutions.

Stability a Prime Requisite of Any Constitutional System.- One of the first requisites of any constitutional system is that it shall have a high degree of stability.

It is universally recognized that neither political nor social progress can be achieved when the fundamental law of a land is undergoing constant modification. Not only do frequent changes in the constitutional system of a country necessarily introduce disturbing elements into the life of a people, but the mere fact that such changes are possible, and likely to occur, tends to keep the people stirred up; and the uncertainties regarding the future thereby endangered act as a powerful deterrent upon undertakings of all kinds. More important still the making of frequent changes tends to weaken that allegiance to, and respect for, the government that is such an important factor in securing an orderly conduct of political affairs.

Flexibility Also a Requisite of a Constitutional System.- The high desirability of giving stability to a consti- 
tutional system is questioned by no one. There is, however, another consideration directly opposed to it that is no less important. Were conditions to be met by a government unchangeable; were the political ideas and aspirations of a people always the same; and were the framers of constitutions all-skillful in framing a constitution to meet these conditions and aspirations, it would be possible to frame a constitution of such a character that no need for its subsequent modification would afterwards arise. It need hardly be said that no one of these three conditions actually obtains. Conditions of life are constantly changing. The rise of the factory system, the conversion of most western countries from a nearly exclusively agricultural community to one in which industry, as distinguished from agriculture, is highly developed, the aggregation of people in industrial centers and large cities, the development of means of communication, and the enormously greater complexity of modern life, as compared with that of former times, to mention but a few of the changes which have taken place in recent years and are still at work, have altered fundamentally the problems that a government has to meet.

No less fundamental are the changes that have taken, and are taking, place in respect to the attitude of the individual towards the State and the government through which the latter acts. From an organ having but a few essential functions, such as the conduct of foreign relations, the maintenance of order and the protection of life and property, the government is now looked upon as an instrument through which all matters affecting the general welfare may be handled. To the great importance attached to the obligations of the government in respect to the protection of the liberties of individuals, as individuals, has succeeded an attitude of mind where the emphasis is rather 
laid upon the obligation of the government to promote social welfare, to take the steps necessary to bring about a greater equality of opportunities and a more equitable distribution of wealth, income and means of enjoyment. It is not too much to say that the change that has thus taken place in respect to the attitude of mind towards the functions of government during the past few generations is little short of revolutionary.

Finally, it is hardly necessary to state that the framers of constitutions are not infallible; and it is certain that actual experience under a system will reveal features in respect to which improvements can with advantage be made. Especially is this true when the system framed represents one with which the people concerned have never had any practical experience. The attempt made in the latter part of the eighteenth and in the nineteenth centuries to create governments based on the representative principle represented a great experiment in government. Though the principle that it was sought to establish might be clear enough there was almost nothing to guide constitution framers in respect to the proper means to be employed in putting this principle into operation. It would have been a miracle had they made no errors.

It follows inexorably from this that the constitution of a modern State should be susceptible of progressive change or growth as errors of judgment in its framing are revealed by experience, as conditions change, and as the political aspirations and beliefs of the people undergo alteration. We have thus then two directly opposing considerations which have to be met - the need for stability and the equal need for flexibility. The problem is to adopt a policy and procedure in respect to the amendability of constitutions that will represent a compromise between the two - 
a scheme which, while permitting changes to be made, will yet insure that they will not be effected until it is certain that they represent real improvements, and correspond to the real, and not a merely temporary, change in the political desires of the people.

Two Methods of Securing Both Stability and Flexibility: Proper Drafting of the Constitution and Provision of Adequate Means for Effecting Constitutional Changes.-A study of the problem of harmonizing these two apparently conflicting and opposing principles of stability and flexibility shows that two means may be employed for this purpose: (I) the drafting of the provisions of the constitution in such a way that great freedom of action is possible under them; and (2) the provision of means through which the constitution as first drafted may be formally amended.

Of these two methods the first, if not the most important, is the one upon which reliance should primarily be placed. Provision of means by which a difficulty may be avoided is always preferable to provision of means by which a difficulty after it has arisen may be met. Flexibility is not synonymous with susceptibility to change. It indeed is almost the opposite of this. A flexible object is one which can be bent without breaking; one that can be adjusted to new conditions without undergoing any structural change. In this sense stability and flexibility are not incompatible qualities. The presence of the latter attribute may indeed add strength to the former. The really stable constitution is thus, in fact, the flexible constitution, the one which is of such a character that it can adjust itself to new conditions and to new demands without itself undergoing structural change.

We have here to do with what is probably the most im- 
portant consideration involved in the whole problem of constitution drafting. It is one that should never be out of the minds of those having responsibility for this work. The extent to which it is met determines in no small degree the excellence of work performed. Turning now to the means that may be employed in meeting this consideration it will be found that but one method is possible; that of confining the provisions of the constitution as far as possible to absolutely essential features and leaving all less essential matters to the determination of the government which is to be established by the constitution. To the extent to which this principle is violated there is created a constitutional system which is rigid but not necessarily stable, since to that extent the probability of necessity for change in the constitution itself is correspondingly increased.

To illustrate, a constitution may provide, as does our federal constitution, in effect, though not in so many words, that the conduct of the administrative affairs of the government shall be entrusted to such administrative departments as may be created by the government from time to time for that purpose; or, it may provide, as does that of China, that these affairs shall be entrusted to certain enumerated departments. In both of these cases the same fundamental provision is made that the administrative affairs of the government shall be conducted by administrative departments. In the former, however, the whole matter of determining the number, designation and jurisdiction of these departments is left to the decision of the government established by the constitution. The hands of the latter are left free to take such action as conditions at any time warrant. The constitution in this respect thus has a high degree of both flexibility and stability - flexibility since provision once made can readily be changed as new conditions, demands 
or opinions arise, stability since the likelihood of any change in the constitution itself being necessary is rendered extremely remote. In the latter case we have, instead of flexibility, rigidity, instead of stability, instability. For, with a definite determination of the number and character of the administrative departments that shall be employed, all opportunity is destroyed for readjusting the administrative organization to meet new conditions, needs or desires, and a direct incentive for the effecting of changes in the constitution is created, since, by that means alone, can needed changes in this respect be made.

The foregoing but illustrates a choice that must be made in respect to almost every feature of a constitution. That document may thus content itself with providing that justice or law shall be administered through a system of courts organized on a certain basis, or it may seek to set forth in detail the scheme of judicial tribunals to be established, the manner of selecting the judicial officers to man them, the procedure to be followed, etc. It may content itself with providing for a legislature of a certain character, or may seek to determine precisely how that body shall, not only be constituted, but the manner in which it shall exercise its powers. It may give a broad grant of powers to the government to be established, or it may restrict these powers by all sorts of limitations and restrictions.

A primary principle of constitution drafting should, therefore, be that of giving to the constitution the widest possible flexibility compatible with definitely determining the general character, organization, jurisdiction and modes of procedure of the government to be established by it. No detail should be inserted unless this detail is essential in order that the general scheme of government and its powers may be made clear. 
The Constitution of the United States a Model of Proper Drafting. - In no respect has our federal constitution received greater praise, or merited it, than in respect to this point. It stands today a model of self restraint, as it were, in respect to the confining of its provisions to those features which were deemed to be absolutely essential. That exceptions to this occur, is due, not to any lack of appreciation of the importance of this principle, and of desire to follow it, but to the fact that no judgment can be infallible. To this fact, primarily, is due the fact that the United States, notwithstanding the tremendous changes which have taken place in conditions, problems of government and political thought, has had a progressive development of its political life and institutions with but few changes in its constitution as first drafted.

Defective Character of the Constitutions of Many of the States of the United States from the Standpoint of Proper Drafting.- - If we turn from our federal to our state constitutions we find quite a different condition of affairs. The earlier constitutions were marked by an adherence to this principle of dealing with essentials and of expressing provisions in general terms to an extent almost as marked as in the case of the federal constitution. Later constitutions have departed widely from this principle. Many of the more recent constitutions represent the attempt to regulate in the greatest practicable detail the manner in which the government shall be organized, the jurisdiction or power of each organ and the precise manner in which these powers shall be exercised. The reason for this change in policy, which is one which cannot but be regretted, is not difficult to find. It consists in the fact that the electorate has not been satisfied with the manner in which its agent, the government, has discharged the duties entrusted to it. Par- 
ticularly has it been dissatisfied with the working of that part of the government to which it entrusted the exercise of legislative powers. That the electorate was justified in being dissatisfied with the manner in which its representatives performed their duties is unquestionable. It is when we turn to the means taken by the electorate to remedy this condition of affairs that one may well doubt whether the proper line of action was taken. The question of the reform of our state governments is too large a one for us to enter upon in the present place. It is pertinent, however, to point out that the electorates of our states, having discovered that the governments they had established did not work satisfactorily, had two alternatives open to them. They could either have sought to discover and correct the defects in the system of government established by them; or have sought to control the abuse of power, or failure to exercise power properly, by themselves prescribing in greater detail how the power granted should be exercised. For the most part they have chosen the latter alternative. In doing so a great mistake has been made. The failure of state governments has been due, not to the fact that too broad powers have been granted to them, but to the fact that the problem of distributing these powers among the several organs of government was not properly worked out, and the further failure that adequate provision was not made by which the electorate might exercise its second great function, that of holding its agent to a strict accountability for the manner in which it discharged the duties placed upon it. The fault in other words was the fault of the electorate. It first failed to work out properly the problem of government, and then failed to discharge properly its duties as a principal, or rather failed to provide itself with the means for discharging these duties properly. 
A due appreciation of this fact would have led it, not to lessen the power of government, to tie its hands, as it were, and thus render it if anything more ineffective, but to have corrected the defects in respect to the location of powers within the government.

Early Constitutions Characterized by Excessive Rigidity. - There can be little doubt that almost all the earlier constitutions, that is, those which were adopted in the latter part of the eighteenth or first half of the nineteenth centuries were characterized by an excessive rigidity. Certain of them were in terms declared to be unchangeable. Others imposed such conditions for the effecting of a change as to make them in practice almost immutable. This was due to various causes. In the first place political thought was largely dominated by the idea of natural law. The belief was widely held that there were certain rights, and certain political principles which owed their validity to natural law, and were consequently true for all time and under all conditions. Believing in this, it was the desire of constitution framers, not only to incorporate these rights and principles in the constitutions they were framing, but to incorporate them in such a way that they could not be departed from, or only departed from with extreme difficulty.

In the second place the world had not yet come under the influence of the evolutionary point of view. It was not until the middle of the nineteenth century that Darwin and Wallace made their epoch-making contribution to natural science that existing forms of life have attained their present character as the result of long evolutionary processes and attempted to formulate the laws governing this change. This contribution revolutionized, not only the study of natural science, but that of practically all thought. In all 
fields, whether of morals, political institutions or social conventions, it became apparent that the same principle could be applied in interpreting present conditions. The idea that existing conditions were permanent was destroyed. Thought was turned from the attempt to discover eternal verities to that of the discovery of laws of growth, development and adaptation.

In no field was this changed attitude of mind more radical, or productive of more important results, than in that of politics. The problem of politics, from being one to determine and establish a system corresponding to natural law, became one to determine and establish a system which, while conforming to existing conditions, should be susceptible of progressive change as the conditions to be met changed.

A third reason for the placing of great difficulties in the way of change in constitutional provisions arose from the fact that these early constitutions represented the establishment of Popular Government as opposed to Autocracy. The feeling was strong that though the former had won a victory over the latter, all danger of a restoration of Absolutism was by no means over. Coupled with this was an equal fear that the people might go to the other excess and establish a political Democracy which, in their eyes, meant little more than giving the country over to the dangers of mob rule. There was nothing like the belief or trust in Democracy that prevails at the present time. It was for these reasons, and to avoid these dangers, that extreme precautions were taken to make constitutions difficult of amendment.

Present Tendency Towards More Flexible Constitutions. - It is hardly necessary to state that present conditions are quite different from what they were at the time 


\section{8 \\ THE GOVERNMENT OF MODERN STATES}

these early constitutions were adopted. The fear of the reestablishment of an Autocracy has largely passed away. Political thought is no longer dominated by the belief in natural law. The effort is no longer made to devise political institutions that are of universal applicability. The position is now held that the excellence of a political system is determined by the extent to which it conforms to actual conditions, and consequently that such systems should change as conditions change. It follows inevitably from this that political thought now holds that it was a great mistake to attempt to establish a constitutional system that was unchangeable, or one that could be changed only with extreme difficulty; and that all constitutions should contain provisions making it possible for its provisions to be changed when it is clearly evident that change is needed.

In the case of the constitution of the United States the feeling is now strong that the provisions contained in it setting forth the manner in which it may be amended are much too restrictive. What these provisions are will receive attention in another place.

Two Methods of Modifying Constitutions: By Formal Act and by Informal Action.- With this knowledge of the general considerations involved in making provision of means by which constitutions may be modified, we now turn to an examination of the several methods of procedure by which such change may be effected. Consideration shows that established constitutions undergo changes in two distinct ways: (I) through the formal alteration of the provisions of the constitution as expressed in writing; and (2) through the informal process of changing the manner in which these provisions work by placing upon them a changed construction or by developing political institutions and practices which profoundly modify the way in which 
they operate in actual practice. Each of these methods requires separate consideration.

Modification of Constitutions by Formal Act.- In practically all cases, States, in adopting constitutions, have recognized that, either as the result of changing ideas or altered conditions, changes would have to be made in their provisions from time to time. With one or two exceptions, therefore, they have inserted in their constitutions provisions setting forth the manner in which such changes may be effected. These provisions are among the most important of any contained in the constitution. In practice they vary widely in different governments. It is, therefore, of extreme importance that the considerations that underlie these variations should be clearly understood.

Distinction Between Constituent and Legislative Powers.- In consiclering this problem of the formal modification of constitutions no progress can be made until a clear grasp is had of the fundamental distinction between what are known as constituent and legislative powers, since the whole question of the methods that shall be employed in effecting constitutional changes centers in the extent to which this distinction is recognized and separate provision for their exercise is made.

Constituent powers are the powers pertaining to the legal sovereign to determine the character, organization, jurisdiction and mode of procedure of the government which shall act for it in the actual conduct of State affairs. They are the powers exercised by a principal in creating and fixing the powers and conduct of an agent. They represent thus the direct exercise of sovereign powers in their most important manifestation. They are from their very nature original, inherent and unlimited.

Legislative powers are the powers possessed by that par- 
ticular organ, or'organs, of the government to which the legal sovereign has entrusted the authority of enacting the subordinate legal regulations required for the carrying out of its functions. They are the powers to frame rules of conduct possessed by an agent. In contradistinction to constituent powers, they are derived, not original, delegated, or specified, not inherent, limited, not unlimited. They extend no further than the grant authorizing their exercise, and must be exercised in strict compliance with the manner laid down in such grant.

It is hardly necessary to point out the importance of this distinction. It lies at the basis of the whole question of legality of acts of the government. It means that, not only must every act of ordinary administration rest upon a legal warrant in order to be valid, but that every act of legislation itself shall have a like warrant. When the Supreme Court of the United States is called upon to decide as to the validity of an act of Congress, it is doing nothing more than pass upon this point, whether Congress has or has not acted within the scope of its delegated authority and in conformity with the procedure laid down for it by the sovereign authority in creating and determining its powers. This matter of the distinction between constituent and legislative powers is one which runs through the whole conduct of government affairs. Here, however, we are interested in it only as it affects the problem of constitutional revision and amendment.

The Distinction in Practice Between Constituent and Legislative Powers and the Manner of Their Exercise the Prime Factor in Determining Methods of Modifying Constitutions. - It would seem that, with a distinction so clear and important as that between the rule-making powers of the legal sovereign and the agency government, separate 
provision would be made for the exercise of the two. The situation is one which would seem to call for means by which the sovereign electorate might, independently of its agent, from time to time determine for itself what changes, if any, it desired to make in respect to the character, powers, or procedure of such agent. Actually, however, this is by no means always, nor even usually, the case. A study of the provisions of existing constitutions regulating the natter of constitutional change shows that to a very large extent the sovereign electorate, instead of retaining in its own hands the exercise of this its most essential power, has, in fact, surrendered it into the hands of its agent, the government. The extent to which it has done so and the conditions that it has imposed upon its exercise determine the whole character of the system that it has established for the revision and amendment of constitutions.

System of Complete Surrender by the Electorate of the Exercise of Constituent Powers to the Government. - With this as a principle of classification of methods of constitutional revision and amendment, we have first to consider the case where the electorate surrenders, or acquiesces in the surrender absolutely of the exercise of constituent powers into the hands of the government. This lakes place where no provision is made in the constitution for the electorate, acting on its own initiative, to propose amendments to, or a revision of, the constitution, or to ratify or reject propøsals that may emanate from the government. Where this system is adopted we have the anomalous situation that the government, though theoretically but an agent, and morally responsible to its principal, the electorate, is, in fact, independent of the latter. It determines for itself its own character, organization, powers and procedure. The government in fact becomes 
the legal sovereign, political sovereignty only remaining with the electorate.

Complete Surrender to the Government of the Exercise of Constituent Powers May or May Not Involve Abolition of the Legal Distinction Between Constituent and Legislative Powers.- This system of constitutional determination may or may not involve an abolition, from the legal point of view, of the distinction between constituent and legislative powers. Thus the electorate, in surrendering the exercise of constituent power into the hands of the government, may provide that the latter shall exercise it through the same organs and with precisely the same procedure that is employed in exercising its legislative powers; or, it may provide that the two powers shall be exercised through separate organs or, if the same organs are employed, that use shall be made of a different procedure. If the former of these two methods is employed the legal distinction between the two powers is totally destroyed. It becomes impossible to distinguish between a constitutional enactment and an ordinary statute, and the courts in fact make no attempt to do so. The result is that one is justified in saying that a State with this system has no legal, though it may have a political, constitution.

If the second policy is pursued the distinction between the two powers is maintained intact. Manifestly the object sought in maintaining this distinction is to secure, if possible, a situation where what may be called the fundamental political law of the land; that is, the law determining the character, powers and general conduct of the government, shall not be subject to change with the same ease as laws of a less important or basic character. Some of the more important devices employed in securing this end are: That a revision or amendment of the constitution 
can be effected only by the legislative chambers, specially organizing themselves into a constitutional convention for that purpose; that action will require the affirmative vote of an absolute majority of the entire assembly instead of a majority of a quorum, as in the case of ordinary legislation, or a vote greater than an absolute majority, such as a two-thirds or three-fourths vote; that affirmative action will have to be taken by two successive legislatures, etc. This latter method is important since it provides for a means by which the electorate may indirectly at least participate in the work.

The English System an Example of Complete Surrender to the Government of the Exercise of Constituent Powers and Abolition of the Legal Distinction Between Constituent and Legislative Powers.- The English political system furnishes a perfect example where the electorate has not only wholly surrendered to the government the exercise of constituent powers, or, to speak more correctly, has acquiesced in the complete exercise by that body of constituent powers, but has imposed upon that body no obligation to exercise these powers in any manner different from that followed in the enactment of ordinary law. The result is that, in England, today, not only does the exercise of complete sovereignty reside in the government itself, but no legal distinction exists between constituent and legislative powers. This is the secret of the sovereignty of Parliament, which is so justly deemed to be such a distinctive feature of the English political system and the justification of the statement often made that England has no constitution.

It is hardly conceivable that a people desiring to organize a political system resting upon the principle of popular sovereignty should by deliberate act create a government of 
this character. The explanation of its existence in the case of England, and the fact that it there gives satisfactory results in practice, are found in three facts: (I) the historical conditions under which it. has come into existence by a process of gradual evolution from an Autocracy; (2) the development of certain canons of political practice, known as conventions of the constitution which, while having no legal force, are yet held to be almost as binding as though possessing that attribute; and (3) the development, outside of the government as it were, of a body of law, known as the common law, an essential feature of which is the protection of personal rights.

Among these canons of political conduct, or constitutional conventions, to use the term more usually employed, the most important from the standpoint of constitutional modification, is that Parliament, notwithstanding its legal power so to do, actually shall pass no act having for its purpose the effecting of a material change in the political system of the country until an approval of such change has been given by the politically sovereign electorate. This approval is given by the latter through a general election placing in power the party pledged to put into effect the change proposed. This convention though not a legal obligation is none the less effective, since a disregard of it in any vital respect would in all likelihood lead to an opposition that would drive the offending Parliament from power.

Though this system has, as has been stated, given very satisfactory results, we should not, however, blind our eyes to the fact that it is one which can be expected to work satisfactorily only under the special conditions which have made it workable in Great Britain and that even there it by no means always works smoothly. Whatever may be the fact in the case of Great Britain, it is certainly true 
that, as a general proposition, a failure to make a distinction of such importance as that between the exercise of constituent and legislative powers throws open the door to abuse of power in communities not having had the political development of that country and not possessed of that inherited and ingrained attitude of mind towards the functions of the government, and the manner of their exercise, and of political obligations in general, which is so characteristic an attribute of the English people.

In the second place, it will be noted that, under the English system, not only has the electorate absolutely no legal means by which it may initiate and have considered proposals for constitutional changes, but it has no means by which it may directly express its opinions regarding proposals of this character originating with its representative, Parliament. The only way in which it can approve or disapprove of a proposed change is by supporting or defeating the party pledged to put into effect such change. It may well happen that an electorate may desire that a certain party shall have charge of the government while it is opposed to that particular feature of this party's program represented by the proposed change. It is then placed in the difficult position where it has to either endorse a proposal with which it is not in accord or defeat the party with whose general policy it is in agreement and by which it wishes to be represented in Parliament. This situation was very much in evidence during the critical period of 1909I4 when the momentous issues were up for decision regarding the political status of Ireland, the power of the House of Commons in respect to matters of finance, and the position and power of the House of Lords in the political system, matters going to the very foundation of the political system of the country. In no one of these cases did the 
electorate have the opportunity of expressing its opinior squarely upon the single issue involved.

The French System an Example of the Complete Sur render to the Government of the Exercise of Constituen Powers with Maintenance of the Legal Distinction Be tween Constituent and Legislative Powers. - The politi cal system of France furnishes an excellent example o where the electorate has pursued the second policy in sur rendering full constituent powers to the government. W have seen that the present constitution of France was no only adopted by a body which was not expressly elected by the people as a constituent assembly, but that, after it wa framed, it was not even referred to the people for ratifica tion. This constitution, which consists of three so-called constitutional laws enacted February 24, February 25 an July 16,1875 , in like manner accords to the people no par ticipation in the effecting of constitutional changes, eithe in the way of initiating proposals for change, or in th ratification of changes proposed by the government. I does, however, provide that a special procedure shall be em ployed by the legislature in effecting constitutional revision and, by so doing, maintains the distinction between con stitutional laws and ordinary statutes. The provisions 0 the constitution governing this matter are as follows: ${ }^{1}$

The chambers shall have the right by separate resolution, take in each by an absolute majority of votes, either upon their own in itiation, or upon the request of the President of the Republic, to de clare a revision of the constitutional laws necessary.

After each of the two chambers shall have come to this decision they shall meet together in National Assembly to proceed with th revision.

The acts effecting revision of the constitutional laws, in whole 0

${ }^{1}$ Constitutional laws on the Organization of the Public Powers, Feb 25,1875, Art. 8. 
n part, shall be passed by an absolute majority of the members :cmposing the National Assembly.

During the continuance, however, of the powers conferred by the aw of Nov. 20, r873, upon Marshal de MacMahon, this revision hall take place only upon the initiation of the President of the Republic.

It will be seen from the foregoing that, though provision $s$ made for the exercise of constituent powers in a manner lifferent from that employed in the exercise of legislative powers, the two powers are, not only as wholly vested in he government as in the English system, but are exercised by what is in effect the same organ of government. Furthermore, it is of importance to note that the special safeguards which are purported to be thrown around the effecting of constitutional changes are from the legal standpoint more or less illusory. This arises from the fact that in France no court is deemed to have the power to declare a law duly enacted by the National Assembly invalid. The latter body thus has the power to ignore the requirements of the constitution regarding the employment of a special procedure in effecting constitutional changes. It can thus pass acts, which will be enforced, which are not in conformity with the constitution and which thus in effect constitute modifications of that document.

In this connection another fact of importance should be noted. This is that, in France, notwithstanding the requirement of a special procedure in effecting constitutional changes, a requirement that does not exist in England, neither the same effective safeguard against constitutional change exists as in the latter, nor is the electorate in fact given the same opportunity to express its will regarding proposed constitutional modifications. This arises from the fact that France has not as yet developed as a binding obli- 
gation the convention that no constitutional change of importance shall be effected until a general election has intervened between the proposal and its final consummation. We have here an interesting illustration of the importance of judging political systems by their practical as well as their purely legal workings.

System of Retention by the People of Participation in the Exercise of Constituent Powers. - In marked contrast with the system whereby the exercise of constituent. powers is wholly surrendered to the government is the system under. which the electorate retains in its own hands a participation, and usually a controlling voice, in the exercise of this power. In order to understand the various ways in which this participation can take place certain important distinctions must be made.

$X$ Distinction Between the Revision and the Amendment of Constitutions. - The first of these is the distinction that should be made between the revision of constitutions and their amendment. By revision is meant the operation of reconsidering and reframing the constitution as a whole. By amendment is meant the operation of effecting a change only in some one or more specific features of a constitution. This distinction is not one merely of relative importance of the two operations. The two present quite different considerations in respect to the policy that should be pursued in permitting them. It is one thing to provide means by which a constitution may be changed in some one or more particular features and quite another to provide that the whole question of the character of the constitutional system that a country shall have shall be thrown open to examination and redetermination. It is not to be wondered at therefore that States have pursued different policies in respect to the two; that many, while permitting proposals 
for specific changes to be brought forward and adopted, provide no means whereby an entire revision of their constitution may be effected.

Of equal importance is the fact that radically different methods of procedure are required in carrying through the two operations. In amending a constitution no special organ is required for the consideration, formulation and adoption of a proposal. It is otherwise, however, in the case of a revision. Here, not only must every single feature of the existing constitution be subjected to careful examination, a study be made of the manner in which each has worked in practice, and every alternative provision be considered, but the fundamental character of the constitution as a whole must be inquired into. Such a work can be properly performed only by an organ specially organized for that purpose. The operation of revising a constitution is in fact strictly analogous to that of formulating and adopting a constitution in the first instance. The only important difference between the two is that, in the latter case, the work must be done by a body which determines for itself its procedure while, in the former, it must proceed strictly in accordance with the rules laid down for it in the constitution to be revised.

The Revision of Constitutions.- Where provision is made in a constitution that it may be subjected to wholesale revision two points have to be provided for: (I) the fixing of the means through which a decision shall be arrived at that a revision shall take place; and (2) the providing of the procedure that shall be employed in effecting the revision.

The matter of deciding whether a revision of the constitution shall be entered upon may be determined in a number of ways. The more important methods that have 
been provided in modern constitutions are the following:

The most effective of all methods is that where the constitution makes it mandatory that the work of revision shall be entered upon once in so often. This is accomplished by inserting in the constitution a provision that at certain intervals of years constitutional conventions shall be convened for this purpose.

A second method, somewhat analogous to this, but not so stringent, is that where, instead of making the convening of a constitutional convention mandatory at certain intervals of time, the constitution simply provides that once in so often the question shall be submitted to the electorate as to whether it is its desire that such a convention shall be had. This is the provision in a number of the constitutions of the states of the United States. ${ }^{1}$ If this method of determination is adopted differences may exist in respect to the character of the vote that will be required in order to authorize the assembling of a convention. A bare majority of the votes cast may suffice or there may be required an affirmative vote greater than this. If it is desired to make the requirement very rigid the requirement may be that a certain proportion of the total number of registered voters shall vote for the revision. A point of no little importance is whether this vote shall be had in connection with the regular election of officers of the government or at a special election. If the former is adopted there is danger that the question of revision of the constitution will be deemed to be a party issue and will not be considered to a sufficient extent on its intrinsic merit. If the latter is adopted it is difficult to get a general participation on the part of voters in the election.

Another method of providing for a constitutional revi-

1 For example, Md., Me., Minn., Wis., Va., N. H., and N. Y. 
sion is that where provision is made by the constitution that the question of convening a constitution-revising convention shall be submitted to the people whenever a certain number of qualified voters petition that this be done. This method is known as that of "The Initiative" and is analogous to the Initiative permitted in certain governments in respect to purely legislative matters.

Finally there is the method whereby the determination as to whether the revision of the constitution shall be entered upon is left to the government itself. When this is done, the provision may be; that the government shall determine when the question of revising the constitution shall be submitted to the people; or that the government, without getting any such expression of opinion from the people, shall itself be the authority to determine when the work of revision shall be entered upon.

In respect to the character or composition of the body that shall perform the work of revision, the weight of opinion and experience is in favor of having this body composed of persons specially selected for this purpose. The objections to having the work of revision performed by the legislature, either sitting as such, or reconstituted as a constitutional convention, are two. In the first place the members of that body have not been selected by the electorate on account of their special qualifications for this work. They have been chosen rather as representing particular party divisions or because of their adherence to particular political policies. In all modern communities having a Representative Government there are always men of high legal and other attainments who are not actively engaged in politics and who thus are not members of the legislature, but whose cooperation in the work of determining the political system of the country is very desirable. In the sec- 
ond place it is in the highest degree desirable that, as far as possible, purely party considerations shall be elininated from the work of revising political systems. The ideal is that of getting together a body of the most competent men who, in a purely non-partisan manner, will seek to determine the character of constitution best adapted to the general needs of the community. This cannot possibly be secured where the work of revising the constitution is entrusted to the legislature, either sitting as such, or reconstituted as a constitutional convention.

There remains the final point of the manner in which the work of the constitutional convention shall be ratified. Here two questions of great importance are presented. The first is whether the constitution as revised shall or shall not be submitted to the electorate for ratification. The second is that, if submitted to the electorate, whether the latter will be given an opportunity to pass upon the changes effected in detail, approving some and rejecting others, if they so desire, or whether it must accept or reject the revision as a whole.

The first of these questions, we have already considered to a certain extent in our discussion of the problem of the original adoption of a constitution. There is much to be said in favor of each of the two alternatives that are presented. The devising of a constitutional system is a work requiring the highest order of abilities. The results reached must rest upon considerations that it is difficult adequately to get before a large electorate. There is good ground for the position that the opinion of a carefully selected body of highly qualified representatives is of greater value than that of a general electorate. There is, moreover, no departure from the principle of Representative Government when the electorate gives to a body not constituting a part of the gov- 
ernment the power to act for it in respect to determination of the character of government that shall be provided. On the other hand, there is always the danger that the work of the convention, no matter what its intrinsic excellence, may not represent the real wishes of the electorate, and a system that does not do so violates the essential principle of Popular Government.

In deciding this question as to whether a revision of a constitution should be referred to the people for ratification much will depend upon the particular conditions of each case and especially the character of the electorate. It may thus well be that while ratification by the electorate is desirable in a country such as the United States, it would be undesirable in a country such as China. In the United States practice has varied widely, not only between the several states, but at different periods of our history.

In regard to the second question, also, arguments can be urged in favor of each policy. A political system should possess a unity. Its several parts should all correspond to certain fundamental principles in respect to the possession, location and exercise of political powers. There is thus a danger that if the electorate is permitted to accept some changes and reject others the outcome will be a system lacking cohesion and unity. On the other hand, it is rather a hard alternative to place before an electorate that it must accept changes with which it is not in accord in order to secure other changes that it does desire. In actual practice, however, the choice is not so difficult as would here appear. Most revisions maintain intact the essential principles of the existing constitution. The work of revision thus, for the most part, represents little more than a series of distinct amendments. When this is the case, it would seem preferable that the electorate should be given an op- 
portunity of passing upon each separate amendment proposed. Where, however, the revision provides for a form of government radically different from the one in existence it is preferable that the electorate should be called upon to pass upon but the single question of the adoption or rejection of the revision as a whole.

The Amendment of Constitutions. - In the foregoing we have considered the problem of effecting an entire revision of a constitution. It remains for us to examine the procedure that may be employed in subjecting a constitution to partial changes leaving that document as a whole intact. Modification of a constitution in this way is known as its amendment.

Distinction Between the Initiation, the Adoption, and Ratification of Amendments.- In entering upon this consideration the first point to be noted is that the act of amending a constitution involves three distinct operations: ( $\mathrm{I}$ ) the initiating or bringing forward of proposals for amendments; (2) the consideration, formulation, if need be, and adoption or rejection of these proposals; and (3) the ratification of such action. This threefold distinction is of importance since, not only must each point be specially covered in providing means for effecting amendments to constitutions, but the electorate may participate in quite a different way in respect to each.

The Initiation of Amendments. - In respect to the first operation three lines of action are open: (I) that of leaving the initiating of proposals for constitutional amendments to the government; (2) that of entrusting this duty to the electorate; and (3) that of permitting amendments to originate in either of these methods. When the first procedure is adopted, the legislature is usually, if not invariably, designated as the organ to take action. When 
the second method is adopted, the electorate retains to itself the power to initiate and compel consideration of any proposal for a constitutional change that it may desire to bring forward. It exercises this power through the filing with the government of a petition bearing the signature of a certain number, or proportion, of the registered voters. Under the third system, as has been stated, amendments may be originated in either manner.

The first of these methods is the one which, until very recent years, was invariably adopted by the states of the United States. Within the past few years, however, a certain number of states have adopted the third. The second and third methods are the ones which have been generally adopted in Switzerland.

The Adoption of Amendments. - The second step in amending a constitution is that of considering, formulating, if need be, and adopting or rejecting the proposals for changes brought forward. When the first method of originating amendment proposals is employed, the requirement usually exists that the legislature, in acting upon amendment proposals, shall act under a procedure and rules different from those followed when it is considering ordinary legislative proposals. A usual requirement is a vote greater than a majority, usually two-thirds of the votes cast, or an affirmative vote of two-thirds of the total membership of each house. Rarely is the approval of the Governor required as in the case of acts of legislation.

When the second method of initiating proposals is employed, the legislature has no function but that of formulating the proposal, if it is not already definitely formulated, and submitting it to the electorate for final action.

The Ratification of Amendments.- The ratification of an amendment is the act by which an amendment which has 


\section{I36 THE GOVERNMENT OF MODERN STATES}

been adopted by a legislature is finally approved by the authority exercising legal sovereignty. In some cases no distinction is made between the acts of adoption and ratification. This obtains when final power is vested in the legislature of a Representative Government to effect amendments. The usual rule in a Representative Government is, however, that an amendment, after adoption by the legislature, shall be ratified by the electorate before becoming effective. This is the requirement found in the constitutions of all but one of the states of the United States. ${ }^{1}$ Various provisions exist regarding the character of the vote that is required to ratify an amendment. In some cases a majority of the votes cast suffices. In others, a vote greater than a majority is required, or the majority must also represent a certain proportion of the total number of registered voters. Under such a provision an amendment may be defeated even though it receives a large majority of all the votes cast. The object of this provision is to ensure that no constitutional change will be made which does not correspond to a public demand sufficiently strong to ensure that the required number of voters will take the trouble required to endorse it. Another method of ratification is that of requiring the action of the legislature adopting the amendment to be ratified by the next succeeding legislature. This is the Delaware system. Here it will be noted that the electorate, though not voting directly upon the question, has the opportunity of expressing its will indirectly, through the opportunity that is given to it of electing members of the second legislature who favor or approve the ratification of the amendment adopted by the preceding legislature.

When the method of originating amendments through

${ }^{1}$ Reinsch: "American State Legislatures" mentions Delaware as the only exception to this rule. 
petition by electors is employed, provision is always made for submitting the question of the final ratification of the proposed change to the electorate. Here, as in the case of amendments adopted by a legislature, various requirements may exist regarding the vote required for ratification.

Special Problems Involved in the Revision and Amendment of Constitutions of Federal Governments.In a Multiple or Federal Government the problem of constitutional revision or amendment presents certain considerations which are not present in the case of a Unitary Government. Here the important question is presented as to whether the modification of the federal constitution shall be deemed to be one which concerns only the Federal Government and the electorate of the country as a whole or whether action shall be had by, or through, the governments of the constituent states and their electorates individually considered.

This question has been answered in almost diametrically opposite ways by the two leading States having a Federal Government resting upon the principle of Representative Government. In Switzerland, the individual cantons, as such, play no part in effecting a revision or amendment to the federal constitution, with the single exception that ratification of a revision or amendment requires the vote of not only a majority of all the electors voting, but a majority of the voters voting in a majority of the cantons. In the United States action must be had both through and by the governments and electorates of the constituent states acting individually. The interest attaching to the government of our own country warrants our considering the system there prevailing with special detail.

The Revision and Amendment of the Federal Constitution of the United States.-- The manner in which our 
federal constitution may be revised or amended is set forth in Art. V of the Constitution, which reads as follows :

The Congress, whenever two-thirds of both Houses shall deem it necessary, shall prepare amendments to this constitution, or on the application of the legislatures of two-thirds of the several states, shall call a convention for preparing amendments, which in either case shall be valid to all intents and purposes as part of this constitution, when ratified by the legislatures of three-fourths of the several states or by conventions in three-fourths thereof, as the one or the other mode of ratification may be proposed by the Congress: Provided that no amendment which may be made prior to the year one thousand eight hundred and eight shall in any manner affect the first and fourth clauses in the ninth section of the first article, and that no state, without its consent, shall be deprived of the equal suffrage in the Senate.

The first point to be noted in respect to this system of constitutional revision and amendment is that, from the strictly legal point of view, it places the United States in the class of governments where the entire power to effect constitutional changes is vested in the government, but where a clear distinction is made between the exercise of constituent and legislative powers. The electorate has no means of originating proposals for constitutional change; nor are changes brought forward and adopted by the government submitted to it for ratification unless the government desires to follow that practice. This the government in practice has never done. Congress has always designated action by the state legislature as the method of ratification.

A second point of importance is that, though the term amendment is the only one used, a clear distinction is in effect made between the two operations of amending and revising the constitution. Amendments are proposed by Congress. It lies with the state governments, however, to 
take the initiative in convening a convention through which all features of the constitution may be passed in review for the purpose of determining what revision of the constitution as a whole may be desirable.

It is not our purpose in the present place to consider the wisdom displayed by our constitutional fathers in meeting the question of the difficulties that should be placed in the way of effecting constitutional changes. It should be noted, however, that the system adopted is one which makes the effecting of such changes exceedingly difficult. This is not due wholly to the stringency of the requirements for the adoption and ratification of proposals when these provisions were adopted. At that time there were but thirteen constituent states and the membership of the two Houses of Congress was very much smaller than is the case at the present time. Under these circumstances it was far less difficult to get the required action than is the case at the present time when there are forty-eight states and the two Houses of Congress have a membership of 96 and 435, respectively. In no small part the great difficulty that now lies in the way of amending the federal constitution has been due to the growth of the country. The question is thus a.fair one, whether, in view of these changed conditions, a change should not be made in respect to the provisions regulating this matter of constitutional change. Certainly the difficulty encountered in effecting amendments postpones the making of changes long after they are urgently needed and are desired by the great bulk of the people. This is especially true in respect to certain technical features of the constitution which it is very important to have made in the interest of efficient government, but which cannot get the support required since they do not involve any great political principle appealing to the imagination of voters. There can be 
little doubt also that the difficulty with which constitutional changes can be effected is largely responsible for the extent to which the Supreme Court has yielded to the pressure to interpret federal powers in such a manner as to make the system workable.

Before leaving this subject it is of interest to call attention to the peculiar way in which the requirement of ratification of amendment proposals by state legislatures has worked in practice. As no time limit is fixed within which ratification by state legislatures of amendments adopted by Congress must be secured, such amendment proposals are deemed to be pending until they are finally ratified. A curious distinction also is made between the conclusiveness of state action when the action is affirmative and when it is negative. If a state legislature votes to ratify an amendment such action is irrevocable: neither it nor a subsequent legislature can rescind the vote then given. Should the vote, however, be against ratification there is nothing to prevent that or any subsequent legislature reconsidering the matter and voting for ratification. It results from this that an amendment adopted by Congress may remain pending before the state legislatures for an indefinite length of time, and may finally be ratified years after action was had by Congress, and after the country as a whole may have changed its mind regarding the advisability of making the change. It is unnecessary to say that an arrangement such as this is hardly a satisfactory one.

The Revision and Amendment of Constitutions of Autocracies. - In governments of an autocratic type the projlem of constitutional change is also a special one. Since, in such governments, the source of all authority is the ruler, and any constitution is, legally, but a document issued by him declaring that he will exercise his powers in the manner 
therein set forth, it follows that no change in this document can be made except with his approval. In an Autocracy, therefore, the ruler is the ratifying authority. In respect to the matter of initiating and formulating amendments, however, the ruler can, if he sees fit, provide that such proposals for changes may originate with some other authority than himself, or he may retain to himself the whole power of even suggesting changes.

The two leading autocracies, Japan in the East and Germany in the West, have pursued different policies in this respect. The former has adhered rigidly to the principle that the whole constitution determining power resides in the ruler, though a certain cooperation in the work, where the ruler believes a change is desirable, is given to the legislative branch of the government. Its constitution thus provides that all proposals for amendment of the constitution must originate with the ruler. It reads (Art. LXXIII) :

When it may become necessary in future to amend the provisions of the present constitution a project to that effect shall be submitted to the Imperial Diet by imperial order.

In Germany, on the other hand, provision is made for the origination, consideration, formulation and adoption of constitutional amendments in precisely the same manner as ordinary legislative proposals. The constitution thus provides (Art. 78) :

Amendments of the constitution shall be made by legislative enactment. They shall be considered as rejected when 14 votes are cast against them in the Bundesrat.

The provisions of the constitution of the Empire by which certain rights are secured to particular states of the Union in relation to the whole may be amended only with the consent of the states affected. 
Under the constitutional system of Germany the Emperor, as King of Prussia, controls absolutely the I4 votes of Prussia in the Bundesrat. The effect of the foregoing provision, therefore, is that, though proposals for the amendment of the constitution may originate and receive consideration in the same manner as any matters of legislation, no change can be made except as it receives the approval of the Emperor. He thus has an absolute veto upon all constitutional changes.

Futility of the Attempt to Declare Certain Provisions of a Constitution Unamendable.-Before leaving this subject it is of interest to note that in a few cases constitution framers, while providing a method whereby the constitution framed by them might be amended, have sought to except certain features of the constitution from the operation of these provisions and to declare them unamendable. Thus Article V of our federal constitution, which determines the manner in which its provisions may be amended, contains the following proviso:

Provided that no amendment which may be made prior to the year one thousand eight hundred and eight sliall in any manter affect the first and fourth clauses in the ninth section of the first article (those relative to the slave trade and capitation taxes) and that no state without its consent shall be deprived of the equal suffrage in the Senate.

The first of these provisions as is seen was declared to be but temporary. The latter, however, represents an effort to make practically unamendable one of the most vital features of our whole constitutional system, that which gives to each state no matter what its size and population equal representation in the Senate.

A like attempt was made to make certain provisions of 
the French constitution unamendable by an amendment to the constitutional laws adopted August 14, 1884. This was done by adding to Section 8 of the Constitutional Law on the Organization of the Public Powers of February 25, 1875, the following:

The republican form of government shall not be made the subject of a proposed revision. Members of families that have reigned in France are ineligible to the presidency of the Republic.

Another example of where an attempt was made to make certain features of a constitution unamendable is furnished by the Provisional Constitution of China promulgated on May I, 19I4. That document declares that stipulations that had been promulgated determining the treatment of the late Emperor, the Imperial Clan, and the Manchus, Mongols, Mohammedans and Thibetans "shall never be modified."

It must be evident that, though provisions of this character may tend to prevent the changes prohibited, they by no means guarantee that they will not be made and that by a strictly-legal method of procedure. Should the time ever arrive, for example, when the people of the United States were firmly convinced that the present system of equal representation of the states in the Senate was inequitable, not consonant with the then existing ideas of nationality, or otherwise unsatisfactory, all that would be required would be the repeal of this provision prohibiting the change by the ordinary method of amending the constitution. This amendment having been made, a further amendment could then be adopted modifying the provisions of the constitution dealing with the composition and manner of election of the members of the Senate.

The Informal Modification of Constitutions.- In 
the foregoing we have considered the manner in which governmental systems undergo modification as the result of formal changes deliberately made in their constitutional documents. We are now to consider how equally farreaching changes may be effected in such systems by a purely informal and, as it were, unconscious change made in the manner in which these systems are made to work in practice. The method here to be considered is essentially the one by which England evolved her constitutional system.

For many years it was believed that England, with her unwritten constitution, had a great advantage over other States, with their written constitutions, in the fact that her system was susceptible to constant evolutionary changes, as new conditions and ideas developed, while those of other States were not. Closer study, however, has revealed the fact that all constitutional systems, whether possessing written constitutions or not, are, if viewed in their practical operation, undergoing changes in this way. Of no country is this more true than of the United States, which, among all countries, is supposed to have the most rigid of constitutions. This is illustrated, not only in the constantly changing construction placed upon the powers of government through decisions of our courts, but in the development of political institutions and practices which profoundly modify our system of government in its actual operation. These institutions and practices are usually designated as extra-constitutional or extra-legal since they find no recognition in the constitution and only to a slight degree in formally enacted laws.

Probably the most striking example of such a change is presented in the manner in which the machinery provided by the constitution for the election of the President and Vice-President has been made to work in practice. The 
system for the election of these officers, as provided for by the constitution, is that the states shall select, in such manner as they see fit, electors equal in number to the number of Senaiors and Representatives to which they are entitled in Congress and that these electors should assemble in their respective states and make known their choice for a President and Vice-President. If no person receives a majority of the votes cast a selection is then to be made by the House of Representatives from among a certain number of candidates having received the highest number of votes. It was the clear intent of the framers of the constitution that the duty of making a choice of these officers should rest with these bodies, and that, in doing so, they should use their own best judgment as to who was most worthy. In providing this method it was deliberately intended to avoid the system of electing a President and Vice President by popular vote. As is well known this intent has been wholly defeated. By developing a system under which electors pledged to vote for a designated candidate are selected by popular vote, the President and Vice President are now in fact elected by what amounts to a popular vote.

Another example of the informal, or extra-constitutional, development of political institutions is found in the President's Cabinet as now constituted. No such body is provided for either by the constitution or any law. It has developed solely as the result of the action of successive Presidents who have felt the need of securing in this way the collective advice of the chief administrative officers of the government. Legally, the President is under no obligation to make use of any such body and, if he does, is free to determine whom he shall make members of it. Actually, however, practice in respect to the composition and functions of this body has so hardened as now to have almost the same 


\section{I46 THE GOVERNMENT OF MODERN STATES}

force as though the character and duties of this body were determined by express provisions of the constitution.

Most important of all political institutions thus informally brought into existence is, however, that of political parties. From beginning to end the constitution makes no reference to any such bodies. There was in fact no idea on the part of the framers of the constitution that such bodies would play any important part in our political life. In so far as thought was given to the subject at all, parties were looked upon as factions dangerous to the welfare of the Republic. It is hardly necessary for us to point out how vital a part these bodies now play, not only in the political life of the nation, but in the actual conduct of governmental affairs. Not the first beginning could be made in comprehending our real governmental system except as we understand the principles underlying the organization and operation of these bodies. They constitute as essential parts of such system as if they were expressly provided for in the constitution. We shall consequently have to devote a considerable amount of attention to them in a later chapter. 


\section{PART IV}

\section{THE DETERMINATION OF THE SCOPE AND POWERS OF. GOVERNMENT}





\section{CHAPTER VIII}

THE JURISDICTION OF GOVERNMENT

In an Autocracy or a Democracy sovereignty both resides in and is exercised by the same agency. In a Representative Government sovereignty is possessed by one body, the people organized as an electorate, and is exercised by another - the government. The relationship that exists between these two bodies is that of principal and agent. It is of prime importance that this relationship of principal and agent which exists between a sovereign electorate in a Representative Government and its government should never be lost sight of. The powers of the sovereign electorate are absolutely without limitation. The government, on the other hand, is but a corporation agency created by the electorate to act for it. Like all corporations it thus has no inherent powers. It can only do those things which it is specifically authorized to do and those things it must do in accordance with the provisions and limitations set forth in its charter or constitution.

Dual Function of a Constitution: Determination of Jurisdiction of Government and Form of Government. With the foregoing in mind, it is evident that a constitution has two clearly distinguishable functions to perform: (I) It must set forth the extent to which power to act is conferred upon an agent, and (2) it must determine the manner in which this power shall be exercised. Sovereignty we have seen connotes absolute unlimited power. By this is meant not merely full, unlimited, political power, but 
full power to do any act that is within the range of physical possibility. From the standpoint of sovereignty there is no distinction between political and other powers. This arises from the very nature of sovereignty. Supreme power must rest somewhere and in a State it rests with the possessor of legal sovereignty. Now political action means collective action, the determination of conduct by a general will. To the extent to which it is exercised it carries with it the subordination of the individual will, the control of individual action. It represents thus a direct limitation upon the freedom or liberty of the individual, as an individual, to do as he chooses.

Now all people, having reached the stage of progress where Popular Government is demanded, are unwilling to accept the idea that their conduct shall be subject in all respects to a general, collective control. They feel that there are certain matters which each individual should determine for himself. To hold otherwise would mean to subject themselves to a control as complete as that which has ever existed under the most absolute and despotic of Monarchies. This being so, it is evident that every sovereign electorate, in providing for the establishment of a government to act for it in respect to the conduct of political affairs, is called upon to make a momentous decision. Though it cannot divest itself of one atom of its own inherent, unlimited powers, it can decide upon the extent to which it will confer the right to exercise these powers upon its agent, the government. The issue here presented to it is thus, whether it will, or will not, draw a distinction between those acts which shall be subject to governmental regulation and those which shall be left to individual determination; and, if it decides to make the distinction, the lines along which it shall be made. To state this in another way, it has to determine 
the relative jurisdictions of the government and the individual. This issue is often stated as one between the individual and the State. This is a wholly erroneous form of statement. No such issue can arise between the State and the individual. The State is legally omnipotent. The issue is one between the government and the individual; and it is the State, acting through its proper organ, that decides the issue.

In seeking thus to delimit the two fields of governmental and individual authority, two methods are open: (I) the powers of government may be enumerated and accurately defined; or (2), a full grant of authority may be given subject to certain specified limitations. The latter is the method almost universally employed. The attempt, in other words, is made to state the things which shall be deemed to be matters purely of individual determination. This statement constitutes what are popularly known as "individual rights " or "liberties," or " constitutional guarantees."

Twofold Character of the Problem of Determining the Jurisdiction of Government.- This problem of determining what the government shall have authority to do, and what it shall not, has two phases: (I) that of determining substantively the limitations that shall be placed on the powers of government; and, (2) that of the means that shall be employed in setting forth these limitations and making provision for their enforcement.

Three Methods of Providing for the Guarantee of Individual Rights. - Examination of the methods actually adopted by States in providing for the guarantee of individual rights, shows that action may be had in three ways: (I) the framers of the constitution may attempt to state these rights in definite form in the constitution and thus impose strict limitations upon the government in respect to 
them; or, (2) they may make a general statement of them in the constitution, but provide that they shall subsequently be more accurately defined, and the conditions under which they shall be valid be more closely determined, by the government itself, acting in its law-making capacity; or, (3) they may refrain from all mention of them in the constitution and thus leave the question wholly one for legislative determination. These three alternatives, it will be observed, are in reality the two extremes of placing absolute limitation upon the powers of the government, of placing no limitation at all, and a compromise between the two.

The Method of the United States That of Definite Specification in Its Constitution.- Each of these three policies has been followed by one or more leading nations. Of nations which have followed the first policy, the leading example is the United States. In the case of this State, the people, in framing both their federal constitution and the constitutions of the several constituent states, have incorporated in those documents definite statements of individual rights in such a form as to remove absolutely from the government practically all power to take action representing in any way an infringement of them. Neither the President nor Congress, nor the two combined, can perform any act interfering with these rights as so stated. Effective means, moreover, are provided through the creation of an independent judiciary, through which the people can protect themselves against any such violation should it be attempted.

Were these rights of an absolute character, the policy thus pursued by the United States undoubtedly represents the one that should be followed by all nations placing a value upon these guarantees of individual liberty. This, however, is not the case. There are many cases where the rights ought to be subject to qualifications and limitations, if the interests 
of others and of the general public are not to suffer. This statement has been abundantly proven by the experience of the United States in attempting to operate under these provisions. It is now the best legal opinion in the United States that, not only has the statement of these rights, in the absolute form in which they appear in the federal and state constitutions, led to an enormous amount of litigation, but that the hands of the governments have been seriously tied in their efforts to introduce legal and social reforms urgently demanded by the people themselves. So serious is the situation that it is almost impossible to enact any important social legislation without having its legal validity immediately challenged in the courts. The government and the people thus find themselves in the position where, in seeking to solve their economic and industrial problems, they have to ask themselves, not merely what do they want to do, but what, in view of our constitutional provisions, is it possible for them to do.

The Method of England That of Refraining from a Definite Statement of Individual Rights. - Of nations which have gone to the other extreme, and imposed no limitations upon the legal powers of the government to take action affecting these rights, the outstanding example is Great Britain. Due, partly to the fact that this country has no written constitution, but chiefly to the doctrine of the supremacy of Parliament, that constitutes one of the root principles of the British political system, the government is subject to no legal limitations upon its powers in respect to individual rights; nor, for that matter, in regard to any other action. Legally, thus, Great Britain has a government with powers as despotic as those ever possessed by any oriental ruler. There is no act, no matter how arbitrary, discriminatory, or unjust it may be, which the British government 
cannot legally perform. Legally, therefore, the personal and political rights of the individual in Great Britain are absolutely without formal protection against the government.

Though this is the situation in Great Britain, from the strictly legal standpoint, it is hardly necessary for us to say that, actually, the rights of the individual are, in that country, respected as in few other nations. This results primarily from the fact that for centuries these rights have constituted a fundamental part of the ordinary law of the land, and as such, are protected and enforced by the courts as are all other laws. This alone, however, would not afford an adequate protection. Subject as they are to modification or abolition at any time by act of the government, the real guarantee that they will not be violated rests in the deep rooted belief of the people that these rights are fundamental, and in the power that the people have to discipline and, if need be, overthrow any administration interfering with these rights in a way that does not meet with their approval.

The Methods of France and Germany Analogous to That of England. - Though no other of the nations is in precisely the same situation, as regards this matter as Great Britain, yet those nations which make no real distinction between the exercise of constituent and of legislative powers; that is, which permit the government by any process to amend the constitution and thus to determine its own powers, must be deemed, as regards this feature of their constitutional system, to belong to the same category as that country. To this class, therefore, belong both France and the German Empire. Not only do the constitutions of these two countries make but slight reference to individual rights, but both permit of their amendment by ordinary legislative proced- 
ure, cr what amounts to nearly the same thing, and neither provide any effective means by which any unconstitutional act on the part of the government can be set aside.

Comparison of the Two Methods.-Comparing these two extremes of policy, it will be seen that each has its advantages and disadvantages. On the one hand, the system of the United States affords a guarantee of private rights that is largely lacking in the other system. In securing this advantage, however, it has subjected itself to the disadvantage of unduly tying the hands of the government and of making it difficult, if not impossible, to control abuses arising from an improper use of such rights. The system of nonconstitutional guarantees, on the other hand, while avoiding these disadvantages, places these rights on no higher plane than any other rights, and thus fails to secure that protection of these fundamental liberties which common opinion demands shall be specially safeguarded.

The Method of Switzerland, Japan and China That of the Statement of Rights in the Constitution Subject to Further Legislative Determination.- These relative advantages and disadvantages have been fully appreciated by those nations which have, in recent years, been confronted with the problem of framing or revising their constitutional systems. They have consequently sought to discover a medium or compromise between the two by which, as far as practicable, the benefits of each will be obtained and the evils avoided. This they have found in the device of formally drafting and incorporating in their constitutions statements of these rights, but providing that the government shall have the power to take such action as may be necessary to prevent their abuse or to enable the government to carry out proper measures of reform looking to the general welfare of the community. This is the policy that has been 
adopted by Switzerland, Japan and China. Thus the constitution of Switzerland provides as follows:

The free exercise of religious worship is guaranteed within the limits compatible with public order and good morals. ...

The freedom of the press is guaranteed, nevertheless the cantons, by law, may enact measures necessary for the suppression of abuses. Such laws shall be submitted for the approval of the Federal Council. The Confederation may also enact penalties for the suppression of press offenses directed against it or its authorities.

Citizens shall have the right to form associations provided that there be in the purpose of such associations or in the means which they employ, nothing illegal or dangerous to the State. The cantons by law may take measures necessary to prevent the abuse of this right.

The Japanese constitution in like manner carefully provides that all the individual rights set forth are subject to further definition and determination by law. Thus, for example, the sections guaranteeing religious toleration and freedom of speech read:

Japanese subjects shall, within limits not prejudicial to peace and order, and not antagonistic to their duties as subjects, enjoy freedom of religious belief.

Japanese subjects shall, within the limits of the law, enjoy liberty of speech, writing, publication, public meetings and associations.

Qualifications of the same character accompany the enumeration of all the other rights guaranteed by the constitution. A like form of statement is employed in the constitution of China.

It is a mistaken view to hold that because these rights can be qualified, or their exercise regulated by legislation, that no advantage has been gained by their statement in the constitution. In the first place, it is a matter of no little significance that a people should, in this most formal manner, 
express their belief in the importance of these rights. Such a declaration cannot fail to exercise a profound influence upon the government in legislating regarding them. In the second place, it will be noted that these rights are effective except as they may be qualified by express legislative action. Now the chief end sought by a statement of these rights is to do away with the old regime of arbitrary infringement of them by an absolute monarch or his officers. The provision that these rights can be curtailed only by legislative action accomplishes this purpose. It should be borne in mind, moreover, that the guarantee of such rights has not the same importance in a State whose government rests upon the principle of popular sovereignty that it has in one whose government rests upon the basis of sovereignty being vested in the hands of an hereditary and irresponsible monarch. The provision, in a State having the former constitutional basis, that these rights can be regulated by legislation is thus only providing that the people, acting through their representatives, can take such action in reference to them as they may from time to time deem wise and proper.

The Nature of Individual Rights. - Theoretically the attempt to divide the whole domain of human activities into two fields, the one embracing acts subject exclusively to individual determination and the other to acts which are open to determination by the government, and to prescribe the conditions that must be observed by the latter in exercising the powers that are assigned to it, open a boundless range of action on the part of different States. Actually, however, modern States have reached a more or less substantial agreement in respect to the character of the provisions that should be made.

Individual Liberty. - In the front rank of restrictions that most nations now believe should be imposed upon the 
powers of government are those having for their purpose to guarantee to the individual the enjoyment of certain fundamental liberties free from governmental interference. The more important of these liberties are : freedom of religious belief, freedom of thought and its expression in speech, writing and publication, freedom of movement and freedom from arbitrary arrest and imprisonment.

The enumeration of these points, in respect to which it is generally held that individuals should be free from governmental control, shows the enormous change that has taken place within the past few centuries in respect to this question of the relation that should exist between the individual and his government. In former times no one of these liberties existed. Governments deemed it to be, not only within their province, but their duty to prescribe the religious beliefs of their citizens, to control, in so far as they could, thought and its expression in any manner, to regulate the movements of individuals and to arrest and imprison them as they deemed such action desirable. The greatest progress ever made in the political field is the abolition of this condition and the establishment of the principle that there are certain things which should be left as far as possible to individual determination.

Property Rights. - Next to personal liberty man in general prizes the right to own and freely dispose of property. A man's liberty might in practice avail him little if a superior authority could at any time deprive him of the fruits of his labors. In the Autocracies of the past, tyranny and abuse of power by the government has been displayed as much in the arbitrary seizure of the property of subjects as in the seizure of their persons. It is not to be wondered at, therefore, that peoples in the framing of their governmental charters should seek to incorporate in them provisions aim- 
ing to insure that their property rights, as well as their rights to personal freedom, shall be secure against arbitrary infringement by the government. In the federal constitution of the United States this finds expression in the provisions :

nor shall (any person) ... be deprived of life, liberty or property without due process of law; nor shall private property be taken for public use without just compensation. (Fifth Amendment).

With the general purpose of these provisions to ensure that a man's property shall not be taken away from him except in a legal manner, and after just compensation has been given to him, no one can find fault. In their practical operation, however, these provisions have in many respects worked badly and have resulted in tying the hands of the government in efforts to effect social reform to an extent not at all contemplated when these amendments were adopted. This unfortunate condition has arisen as the result of the interpretation that the courts have given to the expressions "property" and "due process of law." The former of these terms has been held to include the right of individuals to make contracts. As a consequence of this interpretation many attempts on the part of both the federal and state governments to improve the conditions of the laboring classes by prohibiting employers from requiring excessive hours of labor, or imposing other conditions believed to be detrimental to the health of employees have been defeated by the courts declaring that the laws imposing these restrictions were invalid as constituting a violation of the right of individuals freely to contract relative to the conditions under which their labor will be given.

The term "due process of law" has been given the mean- 
ing of action by a court or judicial tribunal. This has greatly complicated the problem of regulating the rates and conditions of service of public service corporations such as railroads, telephone, telegraph and street railway companies, and the like.

The situation would have been an impossible one but for the fact that appeal could be made to certain other legal principles of our jurisprudence, the most important of which are those relating to the "general police powers" of the State and to the special status of industries deemed to be " affected with a public interest." By giving a broad interpretation to these principles the block to social legislation brought about by the construction given to "property" and "due process of law" has been in a measure overcome.

The condition, however, remains that almost every important phase of social legislation has to run the gauntlet of the courts, and that it is only by fighting a pitched battle between the constitutional provisions relative to property rights and the general legal principles of police powers of the State and industries affected with a public interest that any progress can be made.

The whole subject of what constitutes property, what due process of law, what a legitimate exercise of police powers, what an industry affected with a public interest, constitutes one of the most important branches of constitutional law in the United States and the history of the doctrines involved furnishes one of the most interesting chapters in the whole history of Anglo-American jurisprudence. It has been possible for us here only to make bare mention of it.

Equality Before the Law.- Next in importance to the enjoyment of personal liberty and the right to own property free from governmental interference, must be counted the right of individuals to an equality of treatment before 
the law. That people is only partly free where discriminations exist between different classes in respect to the possession of rights, the extent to which they are called upon to contribute to the support of the government, or their right to appeal to the government for the protection of their rights. In many respects the most important feature of the French Revolution was the sweeping away at one stroke of the great mass of special privileges, restrictions, monopolies, etc., which had characterized the old regime. Next to the establishment of the principle that government should be one of law and not of arbitrary will of a ruler the most important political gain of all time is the establishment of the principle that equality should exist in respect to the rights of all persons to the enjoyment of rights and the protection of the law.

Political Rights. - Up to the present we have been considering the question of those rights which it is held that the individual, as individuals, should have. They represent rights which it is felt should be guaranteed against infringement by the government. There is another class of rights that concern the individual, not in his personal character, but as a citizen. They represent his right, not for protection against the government, but affirmatively to take action in reference to the government. They constitute in a word what may be called his political rights. Among such rights are: the right peaceably to assembly for the discussion of public questions and other matters affecting their common welfare; the right, individually, and collectively, to petition the government; that is, to draft and submit petitions or resolutions making known their wishes or calling attention to conditions of practices on the part of the government which in their opinion constitute abuses or obstacles in the way of naticnal progress; the right to compete for and hold 
office, the right to the exercise of the franchise, etc. Fundamentally these rights have for their purpose to guarantee to the individual the right to exercise a voice in respect to the manner in which his government is organized and conducted. Of this character are the guarantees contained in the federal constitution of the United States which provide that Congress shall pass no law abridging "the right of the people peaceably to assemble and to petition the government for a redress of grievances."

As in the case of personal rights, these political rights, though valid as expressions of general principles, are not absolute in the sense that no limitations or restrictions should be placed on their exercise. Thus, for example, equality in respect to the enjoyment of the electoral franchise, the right to be elected to office, or to compete for and hold office by appointment, does not, or should not, carry with it the idea that reasonable conditions, such as the possession of a minimum degree of education, or certain technical qualifications, or a material interest in the country, such as is represented by the possession of property, may not be imposed as a condition precedent to the enjoyment of such rights. In like manner the right to assemble and to petition the government should be subject to reasonable regulations to ensure that it - is not so exercised as to result in disorder or improper attempts to intimidate or overawe the government authorities in the proper discharge of their duties.

Procedural Rights.- The foregoing rights constitute what are known as substantive rights. Experience has shown, or has seemed to show, that, if the liberties of the people are to be protected against the government, it is desirable that certain restrictions should be placed upon the manner in which the government should proceed in making use of the powers that are granted to it. With this end in 
view many provisions have been inserted in constitutions providing that governments shall proceed in a certain way in performing their duties, or placing certain limitations upon the general powers of the government. These provisions have for their purpose to guarantee what are known as procedural rights. For the most part they relate to legal procedure. The United States has gone much further in this direction than any other country. Among constitutional guarantees of this character contained in the federal constitution may be mentioned the following:

nor shall any State deprive any person of life, liberty or property without due process of law. (Amendment XIV.)

No bill of attainder or ex post facto law shall be passed. (Art. I, Sec. 9, paragraph 3.)

No State shall . . . pass any bill of attainder, ex post facto law, or law impairing the obligation of contracts. (Art. I, Sec. Io, par. I.)

The right of the people to be secure in their persons, houses, papers, and effects, against unreasonable searches and seizures, shall not be violated, and no warrants shall issue, but upon probable cause, supported by oath or affirmation, and particularly describing the place to be searched, and the persons or things to be seized. (Amendment IV.)

No person shall be held to answer for a capital, or otherwise infamous crime, unless on a presentment or indictment of a grand jury, except in cases arising in the land or naval forces, or in the militia, when in actual service in time of war or public danger; nor shall any person be subject for the same offense to be twice put in jeopardy of life or limb; nor shall be compelled in any criminal case to be a witness against himself, nor be deprived of life, liberty, or property, without due process of law. . . (Amendment V.)

In all criminal prosecutions, the accused shall enjoy the right to a speedy and public trial, by an impartial jury of the state and district wherein the crime shall have been committed, which district shall have been previously ascertained by law, and to be informed of the nature and cause of the accusation; to be confronted 
with the witnesses against him; to have compulsory process for obtaining witnesses in his favor, and to have the assistance of counsel for his defense. (Amendment VI.)

In suits at common law, where the value in controversy shall exceed twenty dollars the right of trial by jury shall be preserved, and no fact tried by a jury shall be otherwise re-examined in any court of the United States, than according to the rules of the common law. (Amendment VII.)

Excessive bail shall not be required, nor excessive fines imposed, nor cruel and unusual punishments inflicted. (Amendment VIII.)

No Rights Absolute.- There is a tendency on the part of many to look upon the rights we have been considering as absolute. This is a mistake. All are subject to the important qualification that they are valid only in so far as they are not exercised in such a manner as to interfere with a like right on the part of other individuals or to constitute a danger to the State. Thus the highest right of all, that to life, is set aside when the government inflicts the penalty of death sentence for the commission of high crimes, sedition, conspiracy against the State or treason. Personal freedom is abolished when persons are imprisoned as the result of commission of crimes. Property is taken away in the form of fines or compulsory contributions in the form of taxes for the support of the government; and the right to dispose of property after death is everywhere regulated by law. Indirectly a government may set a limit to, or interfere with, the accumulation of property through the enactment of progressive inheritance, income and property taxes. Though freedom of religious belief and of thought generally may not be controlled, its expression may be regulated in many ways.

Individual Rights Versus Social Rights.-This question of individual rights raises an exceedingly important 
question. This is the extent to which such rights should be permitted when their possession or exercise results in injury to the general welfare. For example, the right of an individual to make such use of his property as long as he does not interfere with a like right on the part of others may be of great value to the individual as an individual; but this right may produce social consequences which are in the highest degree injurious. We see this constantly in evidence in the freedom enjoyed in the United States by individuals to erect such houses as they desire upon lots owned by them in large cities. As a result of this freedom an individual by erecting a business structure in a residential quarter of a city, or by erecting a building out of keeping with the character of structures already erected, may seriously damage the general appearance of a quarter or street. Even if the value of adjacent property is not depreciated, the community as a whole has suffered damage through the damage done to the general appearance of the city.

Most existing constitutions in the United States were framed at a time when great intportance was attached to the principles of individual liberty. No more fundamental change has taken place in western society during the past century than the increasing importance that is being attached to social welfare as contrasted with individual welfare, social rights and duties as opposed to individual rights and duties. More and more the feeling is gaining ground that the former should take precedence over the latter. More than this the State, or rather the government, is more and more being looked to as the agent through which social welfare should be promoted. Now the importance of this, from the present standpoint, is that the attempt to promote social welfare brings the government in many cases into direct conflict with individual rights as guaranteed by the 
constitution. It is found that in the attempt to protect their individual liberties, the people have tied their hands in respect to the promotion of the general welfare. The result of this changed attitude of mind towards rights is to open again the whole question of the extent to which it is desirable to attempt to guarantee individual rights by constitutional provisions. The question is being raised whether, either the attempt should not be abandoned, or that express provision should not be made that individual rights must give way to social rights where the two are in conflict.

Fallacy in the Attempt to Justify the Guarantee of Individual Rights by an Appeal to Natural Law.- It is a fact well worth noting that almost from the time when men began to make politics a subject of serious study they have sought to find a justification of the State and of State action by an appeal to some higher law. It was thus by appeal to the principle of the divine right of kings that Autocracy was defended. When Autocracy was overthrown this action was justified by an appeal to the doctrine of popular sovereignty as one corresponding to the inherent principles of political justice. In like manner the attempt has been made to justify the guarantee of individual rights by maintaining that these rights correspond to the principle of natural law. There can be little doubt that it was under the influence of this belief that the provisions guaranteeing them were inserted in our federal and early state constitutions. They were constantly described as the inherent, inalienable, natural rights of man, and are so expressly designated in many early documents. The argument that provision for them would advance the welfare and happiness of the people was not deemed to be sufficient. They had to be supported and justified by the assertion that they were in conformity with natural law. 
Though the belief in the existence of natural law still constitutes an important influence in Anglo-Saxon jurisprudence, the school of natural law has now largely lost its influence. Study has shown that there are no immutable principles of human conduct. Certainly it can be shown that none of the rights constituting the subject of constitutional guarantees are of such an absolute character as to entitle them to the designation of natural laws. In point of fact it can be shown that no one of these rights, with the possible exception of freedom of religious belief and of thought, with which, whether guaranteed or not, it is impossible for the government to interfere, no one of these rights can be accepted in an unqualified manner. Though religious belief and the inner thoughts of a person may be respected, many cases arise where it is desirable to control individuals seeking to translate their convictions into actions. Complete freedom of speech, writing and publication makes possible the evils of slander, libel, and the fostering of sedition, and all modern governments, notwithstanding the fact that freedom of speech is made the subject of a constitutional guarantee, have passed laws limiting this freedom with a view to the prevention of these evils. Freedom to adopt any trade or profession is surrounded by all sorts of limitations or restrictions having for their purpose to ensure that this freedom will not be exercised in such a manner as to work injury to the welfare of others or the general public. The right to acquire, hold and transfer property is also made the subject of minute regulation. In like manner political and procedural rights are now held to be ones which must be justified on the ground of expediency or not at all.

We have devoted some attention to this matter since it is one of great practical importance at the present time. Though the school of natural law is now in its decline, the 
idea of natural rights still has a strong hold upon the imagination of the public and there is scarcely a political or legal change which its advocates do not seek to advance by a contention that the changes advocated rest upon the principle of natural law. The extent to which this argument is made to do duty in the movement for woman's suffrage is a striking illustration of this. It is of prime importance therefore that students of politics should recognize the invalidity of this argument. There may be in a community at any time a prevailing belief in respect to what constitutes justice and what is right, but it is a mistake to take the position that there are any such things as inherent, natural rights that are absolute under all conditions. Every provision of law should find its justification in its intrinsic merits and one of the merits may be that it corresponds to the prevailing belief as to what is right and just. To go further than this, and to attempt to apply such provisions to other communities where conditions are radically different as, for example, would be represented by the immediate conferring of all the rights enjoyed by England and America upon a people with a low degree of civilization, simply because they were held to correspond to natural law, would be the height of folly and could not but lead to disaster. 


\section{CHAPTER IX}

\section{THE FUNCTIONS OF GOVERNMENT}

In the preceding chapter we have considered the problem of the scope of government from one point of view - that of the restrictions and limitations that should be imposed upon governments for the purpose of preserving the exercise of certain rights by individuals free from governmental interference. We have, in other words, approached the problem from the standpoint that all things fall within the scope of government except those things expressly prohibited to it.

It is evident, however, that this problem can be approached from the contrary standpoint; that of proceeding from the position that, primarily, all activities are matters concerning the individual and that the government should concern itself with those things only which have been expressly entrusted to it. Approached from this standpoint the problem of determining the scope of government takes the form of attempting to determine the functions of government, rather than individual rights. Just as adherents of the school of individual rights seek to determine those rights which are believed to be inherent, inalienable, natural rights of the individuals and to guarantee these rights against infringement on the part of governments by inserting in the governmental charters, or constitutions, what are known as declarations or bills of right, so persons, approaching the problem from the contrary standpoint, seek to determine what are the true functions of government and to restrict the operations of governments to these fields. 
The Five Schools of Political Thought.-Approaching the problem of the functions of governments from this standpoint, we may distinguish between at least five distinct schools according to the attitude taken towards what constitutes the proper functions of government: (I) the anarchistic, (2) the individualistic, (3) the collectivistic, (4) the socialistic, and (5) the communistic. The fundamental distinction between these schools is that of the attitude taken by them in respect to the relationship between the individual and the State, the extent to which human conduct should be determined by the individual or the collective will.

The Anarchistic School. - First in order of consideration is the anarchistic school. In the popular mind an anarchist is identified with one who desires to destroy existing government through the use of the bomb and other violent means. It is quite true that many adherents to this school do advocate the use of violence in achieving their ends. It is important to bear in mind, however, that we are here dealing only with means, not the end itself. The really important thing, at least from the standpoint of political science, is the end or the principle which the users of these means seek to make prevail.

The anarchistic school represents the extreme school of individual rights. To its adherents, liberty, individual liberty, is the important thing. All coercion or compulsion such as is implicit in government is inherently and fundamentally wrong and not to be justified. The anarchist appeals from the State law to what he deems to be a higher law, the natural law which gives to each individual the fullest possible freedom to live his life free from restraint on the part of others. There are many persons who belong to this school who do not approve of the use of violence. They constitute what are known as scientific anarchists. Prince 
Kropotkine is probably the most distinguished representative of this class, and in his writings one can find the best exposition of the philosophy of this school.

It is not feasible for us here to attempt any detailed analysis of this philosophy. We may state, however, that it is the belief of this school, not only that the principles for which they stand are theoretically sound, but are susceptible of successful application in practice. It is their belief that common action for the general welfare should rest upon voluntary association rather than state compulsion. They point to the fact that great branches of activities are now conducted in this way. Men form all sorts of associations for common action in which the principle of compulsion is absent. Especially is the great success achieved in the field of distributive cooperation in England and Europe generally referred to as an example of what can be done through purely voluntary association. In boards of trade, chambers of commerce, trade unions, and like organizations, are found other illustrations. ${ }^{1}$

The Individualistic School.- Next in order is the individualistic school. This school has a philosophy similar to that of the anarchists in that both start from the same premise that individual rights and freedom of action is the important thing. The two schools, however, part company in respect to their attitude towards the legitimacy of the State. The anarchist denies that the State has any right to be and that the individual is, therefore, justified in opposing it as an unwarrantable interference with his rights. The indiviclualist holds that this might be true if men were perfect and always acted with justice in their relations with each other. Inasmuch, however, as men are not perfect,

${ }^{1}$ See Kropotkine: "Fields, Factories and Workshops." Ely: "French and German Socialism." 
they hold that some exterior control is essential. They thus justify government as a necessary evil. In doing so they logically hold that this evil should be reduced to the lowest possible term. They hold thus to the principle that that government is the best that governs the least.

Attempted Distinction Between the Essential and Non-Essential Functions of Government.- In applying this philosophy individualists have sought to draw a distinction between what they term the essential and the nonessential functions of government. Admitting that some government is necessary, but looking upon that government almost as an evil, they have sought to determine, largely by a priori reasoning, those functions which modern conditions render essential that governments should perform. These they term the essential functions of government: all other functions actually performed by government are non-essential, and, in their opinion, should be reduced to the lowest possible term, if not wholly eliminated.

The chief of these so-called essential functions are: the enactment and enforcement of law, the administration of justice, the maintenance of order, the protection of life and property and the safeguarding of the community from foreign aggression. The essential functions of government, in a word, are those of the law giver and administrator, the policeman and the soldier. These functions they hold all governments should perform. All other functions they hold to be not only non-essential, but ones which the government should not attempt to perform.

Rise of the School of Individualism. - It is difficult for us at the present time to appreciate the strength of the hold that this school long had upon political thinking and action in both England and America. It dominated political thought during the latter part of the eighteenth and the first 
part of the nineteenth centuries, and exerted a profound influence upon governmental action. It counted Herbert Spencer among its most distinguished adherents. In his "Coming Slavery," "Social Diseases and Worse Remedies," and other writings, Spencer vigorously combated the idea that the government should interfere in any way for the promotion of the general welfare of the people. To him and his followers all legislative and governmental action having for its purpose the determination of labor conditions in factories and mines, with a view to the prevention of the monstrous abuses that were crushing out the lives of little children and reducing labor in general to the condition of mere brutes, were fundamentally wrong in principle. To them these laws represented an unjustifiable interference with individual liberty. The same was true of laws having for their purpose the protection of the public health and indeed all efforts to improve living conditions through governmental action.

This attitude towards government was but one phase of the general emphasis that was laid at that time upon the idea of natural law, the idea that human conduct was subject to a so-called natural law, and that, as far as possible, human conduct should be left to the uncontrolled working of this law. In the biological field it found its expression in the principles of evolution, that progress is achieved through the slow workings of natural law of selection, through the life and death struggle of individuals, the selection of the fit and the elimination of the unfit through this process. In the economic field it furnished the basis for the great school of "laissez faire," or the Manchester school, as it was known in Great Britain, that held to the opinion that industrial conditions, the ownership of property and economic conditions generally, should be deter- 
mined by the free play of economic forces; that competition, the working of the natural law of supply and demand should be the factors regulating economic life; that it was a mistake for the government to interfere in any way with the free working of these natural laws. It was this philosophy that furnished the strongest argument for the establishment of free trade, the destruction of trade monopolies, and other restrictions hampering the free development of commerce and industry.

The Collectivistic School.- Sharply opposed to this school of extreme individualists is the school to which, for want of a better name, we have given the designation of collectivistic. This is the school which may be said to be in the ascendancy at the present time. Just at the time when, in the middle of the nineteenth century, the individualists had seemed to have won a victory all along the line, evidence began to accumulate in overwhelming volume that the results following from the attempt to put its principles into practice were far from satisfactory. The placing of reliance upon self-interest as the mainspring of human conduct, the removal of restraints upon industrial activities, and the leaving of economic and social conditions to be determined by the free play of competition, the laws of supply and demand, and other so-called natural economic laws, utterly failed to bring about a condition increasing individual welfare. The strong used their power to advance their own interests and to oppress the weak in a ruthless manner. Wealth and power tended to concentrate in a few hands and the mass of the people to be reduced to a condition of economic servitude, if not to actual peonage. Furthermore, it became evident that, with the increasing concentration of population in large cities, the rise of production upon a large scale, the growing interdependence of industries, resulting 
from the specialization in industry, etc., there were many things which concerned the people as a whole, and which, if they were not done by the people as a whole would not be done at all, or would be done very imperfectly. Regardless of what might be deemed to be wrong in theory, governments found themselves compelled to enter field after field lying wholly outside of the province of the so-called essential functions of government. It had to take steps for the protection of the public health. It had to regulate the supply of such public utilities as water, gas, electric light, transportation facilities. Public conscience demanded that restrictions be placed upon the right of employers to work women and children in mines and factories.

From an attitude of mind that looked upon government as an evil, public opinion more and more shifted to the position where the government was looked to as an agency having as one of its essential functions the use of its powers in an affirmative way for the promotion of human welfare.

Coincident with, and partly as the result of, this change came the almost complete decay of the old school of natural law, and individual rights. Emphasis began to be placed more and more upon social rights and obligations. Government from being an agent for the protection of individual rights now began to be looked upon as an organ representing all the people as such and having as its prime function the promotion of the general, as opposed to the individual, interests of the community. It is impossible to exaggerate the importance of the revolution in thought that thus took place in respect to the true functions of government. The old school of natural law, personal rights and individualism disappeared almost completely, and in its place arose the modern school of collectivism now firmly in its saddle. This school recognizes no a priori limitations upon the functions 
of the government other than possibly the general belief that/the government should not intervene until it is clear that individual initiative will not be able to meet the requirements of the situation./ It differs radically from the individualistic school in the emphasis that it places upon social obligations, as opposed to individual self-interest, and in the fact that it assigns a positive rôle to government to promote social welfare instead of the negative rôle of doing only that which it is compelled to do in order that individual initiative may have full play. ${ }^{1}$

The Socialistic School.- We have seen that in the anarchistic school there is a body of opinion that places such emphasis upon the matter of individual liberty and initiative that it denies any right on the part of a community to organize politically for the purpose of imposing its collective will upon the individuals composing it. In like manner there is a large school which places such emphasis upon social obligations and the efficacy of collective action that it believes that the conduct of industrial affairs at least should be almost wholly turned over to the government. In its opinion the fundamental causes of social evils are to be found in the unrestricted play of individual self-interest, the competition of individual with individual, each seeking his own welfare. Especially does it hold that the institution of private ownership of land and other instruments of production is basically wrong. The remedy for this condition of affairs it finds in giving to the government full direction and control over the economic life of the people. It is not our intention here to enter upon an examination of the principles of socialism. We are here concerned with this school merely as representing an attitude that can be

${ }^{1}$ For a brilliant survey of this evolution from individualism to collectivism see A. V. Dicey: "Law and Public Opinion in England in the Ninteenth Century." 
and is assumed towards the functions of government. This attitude is, it is evident, the opposite of that of the individualistic school.

The Communistic School.- Radical as is the philosophy of the socialistic school, it does not represent the greatest extreme to which the principles of collectivism can be carried. The socialists look upon government as the means through which the industrial activities of the community shall be exercised or controlled. Their interest is centered in the problem of so organizing and conducting the industrial life of the people that greater equality and justice will obtain in the ownership of property and the production and distribution of wealth. In the enjoyment of this property and the wealth intended for consumption, they recognize that individual desires should in large part control. There is another school, however, which denies even this minimum of individual choice. This school, known as the communistic school, holds that it is the function of government, not only to own or control the means by which wealth is produced and distributed, but in large part its subsequent utilization. This school aims to organize society in such a way that all individuals will, as far as possible, lead a common life. It is thus the very reverse of the anarchistic school.

This school, it is hardly necessary to say, now exerts but little influence. In the past, however, it received no little support and a number of serious efforts were made to put its principles into practice on a small scale. The most important of these efforts was the famous Brook-Farm experiment in the United States, in which so many prominent members of the New England literary circle were interested. At the present time the famous establishment of Godin at Guise, France, represents an effort in this direction which has met with a certain degree of success. 


$$
\text { . }
$$

. 


\section{PART V \\ THE ORGANIZATION OF GOVERNMENTS}


$+$

1

1

$\checkmark$

n. 


\section{CHAPTER X}

THE DISTRIBUTION OF GOVERNMENTAL POWERS TERRITORIALLY

Having determined the scope of the authority of government by fixing the limitations within which it must act, the next question that is presented to our supposititious constitutional convention is that of determining the character of the organization that shall be created for the exercise of such powers as are granted.

The Unity of Government. - In our consideration of the nature of the State we have shown how unity constitutes one of its most essential attributes. It is of the utmost importance that we should appreciate that a like quality attaches to its government. It is unfortunate that the term "government" is employed to designate the several subdivisions of the machinery made use of by a State for the conduct of its affairs; as, for instance, the government of a province, the government of a city, etc., as if there could exist within a State a number of distinct governments at the same time. In a very real sense a State can have but one government. What seem to be separate governments for the administration of public affairs for the country as a whole and such subdivisions as constituent states, provinces, cities and the like are in reality but parts of one governmental system. They all constitute, or should constitute, but parts of one highly integrated scheme of governmental organization. 
Not until we grasp this point can the first advance be made in studying the governmental system of any country. In all cases we must start from the position that a single governmental system is to be brought into existence. The problern is that of the distribution of governmental powers among parts of this system in such a way that together they will constitute one harmonious scheme for the administration of public affairs. How this problem is met determines vitally the character of the governmental system resulting.

We have taken pains to emphasize this point since we, in the United States, are so apt to think that the essential point of difference between our government and that of countries having what is termed a centralized government is that, in the latter, the conduct of public affairs is entrusted to a single government, while, with us, use is made of a number of governments. This is so only in a very special sense. As we shall see, States having so-called centralized governments have political subdivisions corresponding to our states and these divisions have their special governing authorities. The real distinction thus is not between the having of one government or a number, but in respect to the principles in accordance with which a distribution of the totality of governmental powers is made between governmental organs. The United States no less than any other State has a single government.

The Necessity for the Distribution of Governmental Powers.- Though a State can have but one government it is imperative that the sum total of its powers shall be distributed in some way among distinct organs if they are to be effectively exercised. Such is the extent of the territory of modern States, and such the amount and variety of work to be done, that it is impossible for any single authority directly to undertake the performance of all the duties 
that under any system fall within the province of the government. In all governmental systems we thus find a multiplicity of organs and authorities, each with its more or less distinct field of activities and duties, but each maintaining important relations with the other organs and authorities. Together they constitute the government of the State on behalf of which this authority is exercised.

\section{Twofold Method of Distributing Governmental Pow-} ers - Territorial and Functional. - Two methods of distributing governmental powers may be employed - the territorial and the functional. The territorial method is that where the territory of the State is divided into a number of distinct districts each of which is charged with the performance of certain governmental duties within its boundaries, and each of which is provided with a governmental organization through which such performance may be had. The functional method is that where the distribution to particular organs or authorities is made in accordance with the character of the authority to be exercised.

These two methods are not alternative methods. Both are employed in the organization of all modern governments. In their employment a wide divergence of policy is, however, open. Whether the distribution is made in accordance with one policy or another goes far towards determining the fundamental character of the governmental system resulting. According as one principle or another is followed in distributing powers territorially there is brought into existence a type of government known as a "Unitary Government" or one to which the designation of "Multiple Government" may be given, though the term more usually employed is that of "Federal Government." And, according as one or another principle is adopted in respect to the distribution of powers functionally, types of governments are created 
known as Governments of Union of Powers and Governments of Separation of Powers. The importance of these two questions is therefore such that we are warranted in examining them with exceptional care.

\section{Distinction Between Administrative Districts and Po-} litical Subdivisions. - The necessity for the division of the territory of a State into governmental areas arises from two facts: (I) the great extent of territory over which modern States exercise jurisdiction; and (2) the fact that many functions of government have to do with operations affecting the interests of particular localities rather than those of the country as a whole.

Subdivisions for the first reason are made purely for the purpose of facilitating the administration of public affairs. Of this character are the divisions into which countries are divided for the conduct of military affairs, the collection of revenue, the operation of a national postal system, or the performance of any work constituting one of the functions of the general or central government of the State. In all these cases the powers exercised are powers of the central government. The officers exercising authority in the districts are, not officers of the district, but of the central government. The districts themselves have no governmental organization, no governmental powers, no political autonomy. Districts of this character thus are not, properly speaking, political subdivisions; and, in them, we have no territorial distribution of governmental powers in the sense in which we are now employing that term. They are, as stated, merely administrative areas.

If we turn now to subdivisions of a country that are made in order to take account of the fact that certain functions of government affect the interests of localities rather than those of the country as a whole, we have to do with quite a 
different condition of affairs, and one that raises questions exceedingly difficult of satisfactory solution. The problem here is one of splitting up the sum total of governmental powers and distributing them among a number of distinct governmental organizations, each exercising an authority within a fixed territory and in respect to certain determined matters.

The reason for such a splitting up and distribution of governmental powers has already been indicated. It lies in the fact that many functions which it is desirable to assign to government affect exclusively, or primarily, particular communities rather than the country as a whole. It would of course be possible to ignore this distinction and entrust the performance of all these functions to a single central authority. Two powerful reasons exist, however, why this should not be done. The first is that it would be extremely difficult, if not impossible, to secure an efficient administration of governmental affairs in this way. The burden of work and responsibility that would thus be thrown upon the central organization would be greater than it could effectively bear. The attempt on the part of a central government to determine such conditions and needs and to take the action required in each case would result in intolerable expense and delay.

The second is, if possible, of still greater importance. It consists in the fact that, as far as possible, each community should have the management of those governmental affairs which concern itself alone or do not affect the interests of othr communities in such a way as to warrant their intervention. This is so for two reasons : first, because it must be deemed as only just that each community should manage its own affairs; and, second, because the presumption is that affairs will be better administered by the community directly 
interested in the results obtained than by one having no such interest.

It is for these reasons that, as we have stated, all States of any size have divided their territories into political subdivisions, provided each with a governmental organization, and made a distribution of governmental functions among them and the central government.

\section{System of Political Divisions of Modern Governments.} - Not only have all modern States of any size adopted the policy of dividing their territories into political subdivisions for governmental purposes, but, in doing so, they have brought into existence systems of divisions which, from the territorial standpoint, are substantially similar. First in order we have the entire country treated as one political area. The organization managing its political affairs is known as the Central or National Government. Next we find this area subdivided into a relatively small number of grand divisions variously designated as kingdoms, constituent states, provinces, departments, cantons, etc., each with its special government. Each of these grand divisions is, in turn, further subdivided into smaller areas known as districts, counties, townships, communes, etc., each also having its political organization. Theoretically, this process of successive subdivision of the territory of a State for governmental purposes can be carried out indefinitely. Actually, it rarely proceeds beyond this point. If there are any other subdivisions they are usually of a purely administrative character, and as such must, as already pointed out, be carefully distinguished from the political subdivisions of a country which we are now considering.

All countries, moreover, recognize that the problems of government of urban and rural areas are different. All consequently provide for the segregation of distinctly urban 
areas, and the grant to them of special political organizations for the performance of the governmental duties specially affecting them. All of these areas may not be treated alike. Each may be given its special political organization and powers; or the several areas may be divided into classes according to their population or some other criterion. A usual distinction is that between the more populous areas which are designated cities and the smaller or less densely populated centers which are known as villages. It is, however, by no means unusual for areas of the first class to be further divided according to their size into cities of the first class, cities of the second class, and so on.

Finally we have the division of the entire area of the State, or the segregation of special areas, for the performance of certain special functions. Of this character are the areas which are set up for the administration of such matters as education, the construction and maintenance of roads, the care of the public health, the relief of the poor, etc. In the United States this policy of dividing the country into special areas for the performance of particular functions of government has been carried to a very great extent. A recent note in the American Political Science Review thus calls attention to the fact that during the year I9I 5 no less than thirty-six general laws were passed by the states providing for the creation of districts of this character, while provision was made for fifty such districts by special act. The variety of the purposes for which these districts were created is shown by the following heads under which these districts were listed and described: Irrigation districts, levee and drainage districts, flood and river control districts, bulkhead and seawall districts, sanitary and storm sewer districts, school districts, road districts, horticultural and quarantine districts, tuberculosis districts, fire and water 
districts, lighting districts, bridge districts, stone and gravel districts, electrical districts, and land improvement districts. ${ }^{1}$

It will be seen from the foregoing that we may distinguish five distinct categories of political divisions: ( I) the entire area over which the State exercises jurisdiction, (2) major divisions, (3) minor divisions, (4) municipalities, and (5) special activities divisions.

Though five separate kinds of political divisions may thus be recognized, it is desirable for many purposes to consider the last three as constituting a single class. Though distinct in character these three have two things in common: They are established almost invariably solely for the purpose of providing an organization through which matters of purely local concern may be administered; and only in exceptional cases are any general powers of government conferred upon them. Treating these three for present purposes as one class, we therefore have three main classes of political divisions, the governments of which are usually designated as Central Government, Provincial or State Governments and Local Governments.

Analysis of the Problem of the Distribution of Governmental Powers Territorially. - The government of a State, we have pointed out, consists of the totality of the organs or authorities made use of by the State for the exercise of those powers which it has decided shall fall within the province or jurisdiction of government. In practice all States of any size have, as we have seen, made provision for three classes of organizations each exercising authority over a particular area. Concretely, therefore, the problem of the distritution of governmental powers territorially is that of determining the manner in which the sum total of

${ }^{1}$ Legislative Notes and Reviews: Amer. Pol. Sci. Rev., Nov., 1915, pp. 751-759. 
governmental powers shall be distributed among these three classes of organizations.

If we analyze this problem it will be found that in it are involved four distinct questions: (I) the determination of the authority by which the distribution shall be made, (2) the division of the country geographically into political divisions, (3) the determination of the powers of government that shall be conferred upon each class of divisions, and (4) the determination of the character of governmental organzation that shall be provided for each class for the exercise of these powers.

Of these four questions the first is, from the standpoint of political science, much the most important. Decision in respect to it determines the whole character of the governmental system resulting. To it we shall, therefore, devote our chief attention.

Determination of the Authority by Which the Territorial Distribution of Powers Shall Be Made.- Throughout our consideration of the organization of a State and its government we have sought to make clear that the controlling factor determining the type or character of government resulting is in all cases the location of authority. In no case do we find this more true than in respect to the question now under consideration. Upon the possessor of legal sovereignty falls the responsibility for determining the character of government that shall be established for the exercise of the powers which it has decided shall fall within the province of government. This responsibility it can meet in two ways: ( I) by itself taking action; or (2) by delegating to its agent, the government, to act for it. If it acts in the first way we have an example of the exercise of constituent powers, the decision reached thus being made an integral part of the constitution by which a government is established 
and its character and powers defined. If action is had in the second way we have an example of the exercise of legislative powers, the decision being embodied in a document known as a statute or act.

This is the issue which squarely confronts a State in determining the character of the government that shall be established by it. Shall it seek to determine by constitutional enactment how the territory of the State shall be divided into political divisions and the manner in which governmental powers shall be distributed among these divisions; or shall it content itself with creating a single organization in which shall be vested all governmental powers, leaving to that organization the responsibility for determining subsequently the manner in which the powers conferred upon it shall be distributed territorially?

\section{Distinction Between a Unitary and a Multiple Govern-} ment.- This is a momentous question. Next to the question as to whether sovereignty shall be deemed to reside in the ruler or in the people, its answer more than anything else determines the whole character of the governmental system resulting. According as one principle or the other is adopted there is brought into existence a form of government known as a Federal Government, but which can be more expressively designated as a Multiple Government, or one which in political science is known as a Unitary Government. ${ }^{1}$

1 The term "Multiple Government" though not generally recognized in political terminology is here employed in preference to that of "Federal Government" since the latter term is neither sufficiently comprehensive nor does it bring out clearly the essential distinction between the two types of government. The term "Federal Government," properly employed, covers only the case where a dual division of governmental authority has been made between a central govern ment and that of constituent states. It is quite possible for govern 
All modern governments fall within one or the other of these two categories. To the first belong the governments of the United States, Germany and Switzerland; to the second those of Great Britain, France, Italy, Belgium, Russia, Japan and indeed almost all other countries. We have here a classification of governments that is thus of the utmost significance. Manifestly, therefore, it is of prime importance that we should seek to determine the motives which have led to the adoption of one or the other type, the relative advantages of the two types and the character cf the results that each type has given in practice. To us in the United States it raises the great question as to whether the multiple system adopted by us is the one best suited to our needs. The statement that this is the only form of government under which a union of the original thirteen states could be effected undoubtedly describes an historical fact. From this standpoint the action taken was an act of wisdom and was fully justifiable. This, however, does not absolve us from the obligation of seeking to determine by careful study the intrinsic merits and demerits of the two systems. Action that was the best feasible under the circumstances may not be the best that could have been taken had complete freedom of choice existed. Nor does it necessarily follow that the decision thus made is one which equally well meets conditions as they exist at the present day. Principle and expediency are two quite different things.

mental authority to be distributed among three or more separate political bodies. In fact the demand now being made that the status and powers of municipalities be determined by constitutional provisions definitely raises the question of making such a triple division. There is indeed no logical reason why this demand should stop here and not be extended to the determination of the spheres and activities of other political subdivisions by constitutional provision. 
From what has been said it is evident that the distinction between a Unitary and Multiple Government does not lie in the division or non-division of the territory of a State into distinct political areas, since such a division is found in all States of any size; nor even in the nature of the powers or form of government of such subdivisions, but wholly in the difference as regards the authority by which such areas are established and their powers and governmental organization determined.

In a Multiple Government this distribution of powers territorially is made by the body exercising legal sovereignty as an essential part of the task of framing a constitution by which the powers of government and the manner of their exercise are determined. In a Unitary Government no such attempt is made. All the powers of government are conferred in the first instance upon a single central government and that government is left complete freedom to effect such a distribution of these powers territorially as in its opinion is wise. A Unitary Government thus represents the decision on the part of the legal sovereign to make use of a single integrated system of organization for the exercise of all the powers which it has decided shall fall within the province of government; a Multiple Government, the decision to make use of two or more distinct organizations for this purpose.

Theoretically, in the latter case, a people could, in framing a constitution, determine the manner in which the country shall be divided into both major and minor subdivisions and the powers and form of government of each. Actually, however, most, if not all, States which have adopted the multiple form of government have not gone this far. They have contented themselves, in framing their constitutions, with a division of the field of government between a central 
government and those of major divisions, leaving to the latter the responsibility for making such further subdivisions as may be found necessary. They have thus adopted the multiple principle, in so far as the central government and that of the major divisions are concerned, and the unitary principle, in respect to the relations between the latter and minor divisions. It is of interest, however, to note that at the present time there is a strong movement to extend the multiple principle into the field of municipal government. The demand that exists for the constitutional guarantee of what is known as home rule for cities is nothing more than the demand that the legal sovereign in the exercise of its constitution-framing powers shall provide for the organization of municipal governments and determine, in part at least, what shall be their powers and form of organization.

It is evident that this difference in respect to the authority by which a territorial distribution of governmental powers is effected profoundly affects the status of political subdivisions. In a Multiple Government the two or more governing bodies are coordinate. In each case the line of authority runs direct to the legal sovereign. In a Unitary Government the political subdivisions are integral parts of the single central government. They are created, their powers defined, and their form of organization determined, by that government.

Comparison of the Relative Merits of Unitary and Multiple Governments. - Having stated the essential differences between a Unitary and a Multiple Government it remains for us to attempt their comparison, with a view to determining their relative merits and demerits. In doing so we shall put aside, for the present at least, all considerations arising out of the circumstances under which existing governments have been established, or the particular motives, 
historical or otherwise, which have led nations to adopt one type or the other. We shall seek to make the comparison one solely of the intrinsic merits and demerits of the two systems.

Viewed from this standpoint, it is well to state at the very outset that there can be hardly any question but that the unitary type represents by far the most effective form of governmental organization. It is indeed difficult to indicate a single feature in respect to which it is not superior to the multiple type. In the first place the whole problem of the organization of a government is enormously simplified when the decision is made to establish a Unitary Government. The constitution-framing body has but the single task of determining the form of government that shall be established for the general government of the country. It does not have to concern itself with the manner in which the territory shall be divided into political divisions nor the manner in which governmental powers shall be distributed among such divisions in order that they may be most efficiently performed. The whole question of distributing power territorially is treated as a matter of internal organization to be decided by the government itself. When a Multiple Government is established, on the other hand, the constitution-framing body is forced to assume the burden, not merely of providing for two or more governments, but of determining the manner in which the total of governmental powers shall be distributed among them. This is a task of such difficulty that a satisfactory performance of it at one time is almost impossible. We in the United States are only too familiar with the troubles which the attempt that was made to mark off definite fields of activities for the national and the state governments has given rise. Our whole political history has been marked by bitter contests 
regarding the jurisdiction of the two governments. Even now, a century and a quarter after the constitution was adopted, the issues growing out of this attempt have not been all solved.

A second great advantage of the Unitary over the Multiple Government lies in the greater flexibility that it enjoys. In a Multiple Government the jurisdictions of the central government and that of the constituent states have been rigidly fixed by constitutional provisions. The only way by which a change can be effected is therefore that of securing an amendment to the constitution. Were social conditions static and political problems always the same, this might not be an important consideration. It is hardly necessary, however, to say that this is not the case. Certainly it is not true of the period covering the last hundred or hundred and fifty years, during which the governmental systems of most modern States have come into existence. Nor is there any indication that it will be any more true of the immediate future.

Now the most significant feature of the changes that have taken place during this period, and are still in progress, in so far as they affect the problem of government, is that they bear specially on this question of the territorial distribution of powers. If we go back to the middle of the eighteenth century we find a situation of affairs where the several parts of a country were in great part self-contained communities. Each produced the great bulk of the commodities consumed by it. From the economic standpoint they were almost non-competing areas. Under these conditions it was quite feasible that each should manage its own public affairs independently of the others. The development of improved means of communication and of production upon a large scale, to mention but two of the more 


\section{I96 THE GOVERNMENT OF MODERN STATES}

important changes that have taken place since that date, have changed all this. The entire area of States instead of being composed of districts more or less independent industrially have become single competing districts. What were formerly matters of local concern are now of general interest, and as such ones to be regulated or determined by a general authority. It is indeed not too much to say that the transformation that has taken place in the industrial and social life of nations during the past century or century and a half have profoundly changed the whole problem of government.

As bearing on the question now under consideration the important point to be noted is that these changes have not taken place all at once. Only step by step have local interests been transformed into general interests. The situation therefore cannot be met by effecting a change in the distribution of powers at infrequent intervals. One of the essential features of a good governmental system should be that of its ability promptly to modify its organization, and the manner in which its powers are exercised, as new needs and conditions render such change desirable. This feature a Unitary Government possesses and a Multiple Government lacks. Possessed of full powers, a Unitary Government can at all times modify its scheme of internal organization and distribution of powers as need arises. This a Multiple Government cannot do except by way of securing an amendment to the constitution .under which it is working. This, in a State where sovereignty is deened to reside in the people, is an operation which, under the most favorable circumstances, involves a great deal of trouble and delay. Experience, moreover, has shown that success in such an appeal can rarely be obtained until conditions have become almost intolerable. 
It is not necessary, however, to rest the case for the supeiority of the unitary system as regards the element of flexbility upon these general statements. One has only to :xamine the history of governmental conditions in the Inited States to find a striking illustration of the disadrantages under which that country has labored and still is aboring in this respect growing out of its adoption of the riultiple type of government. It was the misfortune of the Inited States to adopt its constitution just on the eve of the rreat changes which, as we have pointed out, have so prooundly altered the practical problem of government. At hat time conditions were not such as to demand that many uffairs should be administered by a national authority. Jne can very well believe that the distribution of governnental powers that was then made between the central ;overnment and those of the constituent states fairly coresponded to conditions then existing, though opinion even it that time was by no means unanimous on that point. No one, however, can question that conditions since then ave radically changed. Notwithstanding this, it has been mpossible to secure any important modifications in the disribution of powers that was then made. The result is that ve are now seeking to secure an administration of public iffairs under a system of distribution of powers that fails n many important respects to correspond to the needs of he situation. We need only mention by way of illustration he matter of the regulation of railway transportation, the usiness of insurance, the elaboration of a proper code for he regulation of the conditions of labor, and the securing of social reforms of various kinds. Only by the subjection ,f the provisions of the constitution to the most strained onstruction, arid by the adoption of such slow and cumberome indirect methods as that of seeking to secure uniform 
action by the several states, is the system made to give ever tolerable results. The changing of the provisions of th constitution prescribing the procedure for amending the constitution so as to make such amendment easier would of course, improve conditions in this respect. Such action however, could never give to a Multiple Government th same flexibility that is enjoyed by a Unitary Government.

The two foregoing advantages of Unitary Government: have to do with the greater ease and promptness with which such a form of government can be established and subse quently modified in order to meet changing conditions. I now we consider the relative merits of the two systems from the standpoint of their practical operation we will find the advantage to lie no less with the unitary system. The out standing feature of the unitary system of government is, as the name implies, unity. All the powers of government are concentrated in the hands of a single set of authorities. Al the organs of government constitute integral parts of one piece of administrative mechanism. All the force of gov. ernment can thus be brought to bear directly upon the problems of administration to be solved. There can be no conflict of authority, no conflict or confusion regarding responsibility for work to be performed, no overlapping of jurisdictions, no duplication of work, plant or organization which cannot be immediately adjusted.

In a Multiple Government the reverse of this is largely true. The powers of government are divided among as many sets of officials as there are central government and major political divisions. The organs of government, instead of being part of one highly integrated piece of administrative machinery, are parts of as many different adminis trative systems. Being coordinate as regards their status, there is no way by which their energies can be directed to a 
common end except by way of securing a voluntary agreement on the part of the several systems to cooperate. This is something which it is often difficult if not impossible to secure. The particular interests of the several divisions are not always identical, and, when this is the case, each is apt to prefer what seems to be its own interests over those of the State as a whole. More serious still this difference of interests may bring the several divisions into sharp conflict with each other or collectively into conflict with the central government.

When the fields of activities are not sharply defined there is certain to be conflicts of jurisdiction, overlapping of authorities and a greater or less duplication of work, plant and organization. This condition of affairs is revealed at scores of points in the federal system of the United States. We need only cite the cases of conflict that result in the attempt to regulate the rates and conditions of service of railways, telegraphs, long distance telephones, pipe lines and other means of transportation, to control the organization and operation of industrial corporations, to work out proper systems of taxation, and to develop the material resources of the country where authority is divided among as many bodies as there are major divisions.

Even when there is no conflict of interests great loss often results when a given work is not under a single direction. Had the United States a Unitary Government all of the topographic, geological and other survey services of the several states, all of their forestry, fishery and analogous services would be coordinated into single united systems for the promotion of the several ends for which they have been created instead of constituting independent services often working at cross purposes. Under the latter system a large duplication of plant and work is inevitable. Each must have its 
own facilities in the way of laboratories, shops, etc., though in many cases a single or a few central plants would suffice to meet the needs of all.

Many of these disadvantages are not absolutely essential features of the multiple system, since it is possible to avoid them under the latter system. The point that it is here desired to make is that the difficulty in doing so is far greater under this system than it is under the unitary system. Indeed under the latter system they are in great part hardly present.

The Problem of Local Self-Government under a Unitary and a Multiple Government. - The chief if not the only advantage claimed for the multiple type of government is that under this system it is possible to secure that decentralization in the administration of governmental affairs, local autonomy, local self-government, or power on the part of each community to determine for itself how its own particular affairs shall be administered, which is generally agreed to be desirable. In no small degree the preference that is shown by communities living under this form of government is due to this feeling. In the minds of the general public, and, indeed, in those of many students of political science, this is the essential difference between the two systems. Deep-rooted as this belief is, it is erroneous. There is nothing in the unitary form of government which does not permit of as great a decentralization in the actual exercise of governmental powers, or the conferring of as great autonomy or powers of self government upon political subdivisions as can be secured in a Multiple Government. Thus, for example, it is apparent that if the framers of our constitution had conferred all governmental powers upon our central government that government could have at once proceeded, by legislative act, to divide the country into 
major divisions corresponding to the existing states and have conferred upon them precisely the same powers and form of government that they now enjoy; or, if it were deemed wiser policy, have granted to the electorates of these divisions the right to frame their own constitutions. This is precisely what the states do in providing for the division of their territories into counties, townships, municipal districts, etc. That, under a Unitary Government, large autonomy and powers of self-government can be given to major political divisions needs no better demonstration than the manner in which provision has been made by the United States for the government of its territories and dependencies. It would be difficult to frame a system under which an administration of the local affairs was more completely vested in the local government than is the case, for example, in Porto Rico today.

The confusion of thought that exists in respect to this matter arises from a failure to distinguish between a centralization of authority and a centralization in respect to the use of this authority. A really centralized government is one in which the central government, instead of making use of agencies to which large powers of discretion are granted, attempts itself directly to administer local affairs. It is in this sense that France, in comparison with other countries, has a highly centralized government, not because it has adopted the unitary form of government.

The Establishment of Multiple Governments Due Almost Wholly to Historical Reasons. - It may be asked how it has come about that, notwithstanding the easily demonstrable superiority of the unitary over the multiple form of government, the latter form has been adopted by so many of the most important and politically most enlightened nations. The answer to this is that the decision 
has been dictated, not by a calm weighing of the relative merits of the two systems, but by historical conditions which have made this the only choice possible. Few States which have once enjoyed independence are willing to exchange their independence for the status of a mere department or province in a larger State. Only stern necessity will induce them to make that partial surrender which is involved in becoming a member of a Confederation or a Federation. Examination of the circumstances under which the great States now possessing a Federal Government, the United States, Germany and Switzerland; adopted that form of government shows that in each case the State itself was established by the union of what had formerly been independent States. In each case also the establishment of a single State with Multiple Government was preceded by an effort on the part of the constituent States to effect a union in which their separate sovereignties would be preserved by leaguing themselves into a Confederacy. It was only after a loose union of this character had wholly failed to meet the necessities of the situation that they were willing to take the next step, that of forming a Federation which should constitute a single State but in which each of the formerly independent States should still retain that larger measure of autonomy or independence of the common government which is the distinguishing characteristic of the federal type of government. It was only with the greatest difficulty that the several constituent States could be induced to take this step. The establishment at that time of a Unitary Government was an historical impossibility.

The Multiple Governments of Central and South America. - The only instances where a Multiple Government has been established, except as the means through 
which a number of previously independent States were induced to constitute themselves into a single State, are furnished by certain of the Central and South American States, notably, Mexico, Brazil and Argentina. Here the motive was the desire to follow the example of the United States. The success of the latter in establishing a government that at once rested upon the principles of popular sovereignty and gave large power of self-government to the several divisions of the country, was believed to be due in large part if not entirely to the adoption by it of the multiple form of government. In this it is evident that they were laboring under a mistake. In view of our present knowledge of the essential differences between the two systems and their relative merits this decision cannot be deemed to have been other than a political blunder. Apart from other disadvantages that have resulted, the difficulties that these States have had in maintaining a stable government must in part at least be attributed to their failure to concentrate all governmental powers in a single strong central government.

Adoption of the Unitary Type of Government by South Africa and China.- It is a matter of no little significance that the two communities which have most recently been called upon to make a decision regarding the character of government that they should have, South Africa and China, have decided in favor of the establishment of a Unitary Government. This decision is all the more remarkable since, in each case, the conditions were not dissimilar from those which had led to the establishment of Federal Governments by other countries in the past. The Union of South Africa was established by bringing under one government political divisions which not only had previously had no political connection with 
each other, except in so far as they owed a common allegiance to Great Britain, but had but recently emerged from a war in which they had taken different sides. In the case of China the problem was that of establishing a general government for provinces and districts which it is true had had a common allegiance to the Chinese Emperor, but which nevertheless had long enjoyed such autonomous powers as to give to them the status of almost independent commonwealths. They had their own armies and, even when their country was attacked by a foreign power, took only such part in the contest as their individual interests dictated.

Notwithstanding these facts the decision was made in each case, when the Union of South Africa was effected in Igoo and the Chinese Republic established in I9II, to adopt a Unitary Government; that is, one in which all governmental powers rest in the first instance in a single central government and the major political divisions have the status of provinces instead of that of constituent states. What makes this decision of special interest is that in each case it was only made after the relative merits of a Unitary and a Multiple Government were carefully canvassed; and, furthermore, that the difficulties encountered by the United States in operating the multiple system were in large part responsible for the choice. The decision indeed may be taken as an illustration of principles of political science overcoming historical conditions.

Universal Tendency in Multiple Governments to Increase the Powers of the Central Government.-The action of South Africa and China in adopting a unitary type of government is but one illustration of the fact that the superior advantages of that type of government are being more and more recognized. Of still greater significance is the fact that in all those States which have made 
a practical trial of Multiple Government there has been a steady movement to counteract the disadvantages resulting from a constitutional distribution of governmental powers territorially by progressively increasing the powers of the central government. In large part the amendments which have been made to the constitutions of Germany and Switzerland have had this for their purpose. No example is presented of the contrary action being taken.

In the United States the same result has been accomplished, in part by constitutional amendment, but, chiefly, by giving to the clauses of the constitution defining the powers of the central government a broadness of interpretation that certainly was never in the contemplation of the framers of the constitution. There can be no question but that the evident need that the powers of the central government should be strengthened has led the Supreme Court to use its utmost ingenuity so to construe the constitutional provisions as to permit of the exercise by it of the broadest powers possible. Finally the United States has witnessed a remarkable use by the central government of the powers which were granted to it. It has entered many fields which were originally deemed to be the particular domain of the several states. We need only cite the fields of education, public works and internal development generally. How great has been the change may be seen from the fact that when the proposal was made to create the present Department of the Interior as one of the executive departments of the Federal Government, it was violently opposed upon the ground that the Federal Government had nothing to do with the internal affairs of the country. Such an attitude would be almost incomprehensible to the present generation.

The greatest evidence of the transformation of opinion that has taken place in the minds of the people regarding 
their government is, however, found in the contrast between their attitude towards the central government and the governments of their states in former times and at the present day. It is well known that in the years immediately following the adoption of the constitution, political honors in the service of the states were preferred to those in that of the central government. It was only a few years, however, before the contrary became true. The steady growth of nationality, of the feeling on the part of the citizen that his primary interest and allegiance was in and to the nation as a whole rather than his particular state is one of the most conspicuous facts of our political history. In connection with this is, not only the constantly increasing tendency to look to the central government for action in meeting public problems as they arise, but the growing conviction that only by such action can many of our most pressing problems be satisfactorily solved. That the old school of state rights is steadily losing its hold upon the people can hardly be questioned. In its place is arising the new school of nationalism and it is well within the possibilities of the future that the principles of this school will sooner or later be made the fundamental doctrine of one of our great political parties.

Interpretation of These Historical Facts.-If now an attempt is made to interpret these historical facts there would seem to be no escape from the important conclusion that the adoption of a multiple form of government represents but an intermediary stage in the political development of the modern State. The problem presented is that of creating a strong single State out of a number of previously independent States. The effecting of such an operation can only be had step by step. The desire for union first finds expression in the formation of a loose union, or league, 
known as a Confederation. From this the next advance is to the formation of a real union known as a Federation in which a single State is created, but a large concession is made to the old feeling of separateness of interests by the adoption of the multiple type of government under which only certain powers of government are conferred upon the central authority. This step made, there immediately develops a steady growth of the spirit of nationalism and, in response to needs actually felt, a progressive development, both absolutely and relatively, of the powers of the central government as opposed to those of the states. So marked is this that it may almost be said that from the moment the system of Multiple Government is adopted the tendency is for efforts to be made to get away from the consequences of the decision that has been made. This attempt, however, is in large part an unconscious one. The result is that the movement towards a unitary form of government takes the several forms of action which we have described rather than steps looking to the deliberate change in the form of government. Only after this movement has gone a long way, and a people have come to a full realization of the essential differences between the two systems, and their relative advantages, can the taking of the final step be made.

This superiority of the unitary type of government over the multiple and its tendency to prevail is excellently stated by President Frank J. Goodnow in his work on Social Reform and the Constitution. After considering briefly the extent to which the more recent Federations, Australia, Canada and Germany, have given greater powers to the central government than in the case of the United States, he concludes :

It may therefore be said that the experience of the civilized world since our constitution was adopted is opposed to a system of 
Federal Government which fixes inalterably and in accordance with some political theory of universal application the jurisdiction of the national and state governments. Furthermore the recently established systems of Federal Government accord greater power to the national government than is ordinarily believed to be accorded by our constitution to the national government of the United States. We are justified therefore in assuming that if the American people were called upon at the present time to frame a scheme of Federal Government they would adopt one which departed in a number of respects from the one under which we now live, and which would resemble that of Germany or Canada in that it would make provision for greater ease of constitutional amendment and for securing to the national government greater powers than are believed by many to be accorded to the government of the United States under the present constitution.

But we are led to such a conclusion, not alone by the experience of the countries in question but as well by the difficulties we encounter in our own country in our attempts to solve the problems which press upon us with the greatest insistence.

In thus pronouncing as we have in favor of the intrinsic merits of the unitary type of government we should not, however, close our eyes to the immense service which the development of the idea of Multiple Government has rendered, and is rendering, in knitting together under a common government peoples whose political interests are largely identical. It is more than probable that some of the great problems of State formation now presented in the case of the Balkan and other Slav countries can only be solved by recourse to this type of government. The pressing character of these problems is in part our justification of the amount of attention that we have paid to this subject.

Determination of the Powers of the Central Government and Those of the Constituent States in a Multiple Government. - Having reached a decision, whether as the result of historical accident or of deliberate choice, regard- 
ing the manner in which the territory of a State shall be divided for governmental purposes, there is next presented the problem of determining the specific powers that shall be assigned to the several political divisions.

Examination of this problem shows that this distribution of powers can be made in three ways: (I) by enumerating in detail the powers which are granted to the central and the state governments, respectively; (2) by specifying the powers granted to the central government and declaring that all the remaining powers of government shall belong to the state governments; or (3) by specifying the powers granted to the state governments and declaring that all the remaining powers of government shall belong to the central government.

For reasons which are easily apparent the first of these methods is rarely if ever employed. Its adoption would require a complete enumeration of the powers of government, something which as yet has never been satisfactorily accomplished, if indeed, owing to constantly changing conditions and political ideas, it is possible of accomplishment in any way that would be permanently satisfactory. The attempt to follow this method would not only give rise to the grave danger that omissions would be made, with the result that neither the central nor the state government would have powers which one or the other should have, but would certainly lead to confusion due to the practical impossibility of so specifying the powers that they would be mutually exclusive. It is evident, therefore, that no matter what the distribution of powers desired it can be better obtained by employing one or the other of the last two methods. In practice, therefore, the real choice of methods may be said to lie between these two.

The decision in regard to this question - whether the 
central government shall be one of enumerated and the state governments one of residuary powers, or vice versa - is a matter of the utmost importance. The importance of this choice consists in the fact that the field of government is constantly widening. Steadily increasing demands are being made upon governments to assume duties which in earlier times were believed to be beyond their province. From entrance into these unoccupied fields the government of enumerated powers is largely barred. It has within itself but limited powers of growth and development. It is, moreover, a well-accepted principle of legal interpretation that when powers are enumerated they must be strictly construed. Before a government of enumerated powers can assume a new duty it must be in a position to show affirmatively that such duty falls within the grant of powers that has been made to it. The government of unenumerated or residuary powers is subject to no such limitation. It can enter any field from which it has not been expressly debarred by positive constitutional provisions. Subject to this limitation it has to show no authority for its action.

An examination of systems of Multiple Government now in existence shows that all Federal Governments representing sovereign States have adopted the policy of making their central governments ones of enumerated and their state governments ones of residuary powers. This is the system of the United States, Germany and Switzerland. In the case of the United States this point is covered by the Tenth Amendment which provides that " the powers not delegated to the United States by the constitution nor prohibited by it to the states, are reserved to the states respectively, or to the people." The reasons for the adoption of this policy are largely historical. The federal union was in each case formed by the union of previously independent 
sovereign States. At the time of the union the latter desired to retain to themselves all governmental powers except such as it was plainly necessary to confer upon the central government in order that an effective union might be established.

For many purposes it is desirable, however, to consider the governments of the Dominion of Canada and Australia as examples of Multiple Governments. Though they are not sovereign States, they have, as regards the administration of their internal affairs, an autonomy almost equal to that of independent States. For the administration of these internal affairs they have a system of government consisting of a central government and governments of provinces analogous to that of the United States. Of these two, Australia has followed the method of distributing powers adopted by the United States, Germany and Switzerland. Canada.has, however, adopted the reverse system of making its provincial governments ones of enumerated and its central government a government of residuary powers. Its government in fact constitutes the only example of this method. For this, if for no other reason, it is one of great interest to the student of political science.

If called upon to decide regarding the relative advantages of these two methods, the preference should unhesitatingly be given to the Canadian system. The prime reason for doing so lies in the fact that a leading feature of the evolution that is now taking place in social conditions is the breaking down of local barriers and the conversion of matters which were formely of purely local interest into ones of general concern. This tendency is seen in almost every field. However one may for sentimental reasons regret it, the fact nevertheless is that more and more the problems of society are becoming ones which can only be met by an au- 
thority representing the general interest. It is desirable therefore that the central government shall have as free a hand as possible to meet these new conditions as they arise. It is impossible to calculate the obstacles that the adoption of the contrary system has thrown in the way of the United States meeting the problems of government with which it has been and is now being called upon to meet. ${ }^{1}$

Relations between the Central Government and those of Constituent States in a Multiple Government.- The great advantages of a Unitary Government over a Multiple Government are, as we have seen, its strength, simplicity and flexibility in operation. It is strong since all authority is concentrated in a single organization and can be fully brought to bear at any time. It is simple, since the problem is not presented of rigidly defining the respective jurisdiction of the central government and that of its political subdivisions. It is flexible in operation since the distribution of powers and duties that is made between the central government and that of its political subdivisions can at any time be altered by mere legislative act.

In contrast with this a Multiple Government is relatively weaker since authority is divided. It is more rigid in operation since changes in the distribution of governmental powers can only be made through the process of formal constitutional amendment. It is more complex, since, with a number of distinct organizations, the problem is presented, not only of defining the respective jurisdictions of these bodies, but their relations to each other. This last problem is one of such importance and is of such direct concern to

1 For an admirable discussion of the superior advantages of the Canadian over the American system, see the paper of Professor Stephen Leacock in the Proceedings of the American Political Science Association, Vol. V, I908, on "The Limitations of Federal Government." 
us since we are living under a Multiple Government that it is desirable to give it special consideration.

The starting point for a consideration of this question is the recognition of the fact that, in principle, a Multiple Government stands for a governmental system in which each government is as nearly as possible a self contained organism and where the only organic relation between the several governments is their common subordination to the same sovereign authority. Under this system each government has its own field of activities and its own set of organs and offices through which to act. Each is independent of the other government. Each revolves in its own orbit, and joint action can only be had through the voluntary agreerient on the part of two or more governments to cooperate for a common or mutual end.

In practice the principle of Multiple Government has never been pushed to this extreme, though, as will be seen, the United States has gone a long way in this direction. As the matter of the interrelations of governments within a Multiple Government is one of departure from, rather than the following of, a principle, it can be best considered by examining the character of the relations which have actually been provided for in the leading Multiple Governments now in operation. This can be most advantageously done by describing the constitutional system of the United States, as regards this point and pointing out the features in respect to which the governments of the other two leading examples of Multiple Governments vary from the provisions thus made.

Intergovernmental Relations in the United States.An analysis of the question of intergovernmental relations in a Multiple Government shows that in it are involved two 
distinct questions: (I) the relations between the central government and those of the constituent states and (2) the relations between the several constituent states. We will consider each of these in turn.

Relations between the Central and the State Governments.- In studying any governmental system the point to which attention should first be directed is that of the manner in which its constitution is adopted, revised and amended. Complete independence of the central and state governments would require that each should maintain relations with its electorate without any intervention or participation on the part of any other government. In the American constitutional system such independence is enjoyed by the governments of the several states but not by the central government. Each state determines for itself the manner in which its constitution shall be adopted and subsequently modified.

Action in respect to the adoption, revision and amendment of the federal constitution, however, is only had through the states. The final adoption of the constitution was had through ratification by the states, not by the general electorate. In respect to the matter of its subsequent revision or amendment, the constitution calls for a participation by the states in both the proposal and ratification of changes. As regards the proposal of amendments it thus provides that, in addition to the right which is conferred upon Congress to propose amendments, the states, if two-thirds of their number concur, can demand the calling of a convention for the proposal of amendments. As regards ratification action must in all cases be had by the states, either through their legislatures or through conventions specially constituted for the purpose, according as one or the other method is prescribed by Congress. Ratification in either case is thus 
had by the states even though the latter in reaching a decision may be required specially to consult their electorates through the assembling of conventions to consider the quescion of ratification. That it is the states rather than the naional electorate which exercise the power of ratification is evidenced by the fact that the vote of each state has the same weight as that of any other state regardless of its populaion or size of its electorate. As the result of this system $t$ is quite possible, not only for a small minority of the ational electorate to prevent the adoption of an amendnent, but for a minority actually to secure a change against he will of a majority.

In this vital respect, therefore, we see that the central yovernment, instead of being independent of, is directly lependent upon the governments of the several states. The existence of these provisions in the opinion of the author yoes a long way towards supporting the contention generally held by the Southern States before the civil war, that he central government was one established by the states ather than by the people of the United States. Forunately, however, that war once for all established the conrary contention that the central government represented the eople directly even though use was made of the states in letermining the will of the people.

The next point of importance in considering the relations of a central and state government is that of the question as o which shall prevail when their action conflicts. Here he position is taken that the central government shall be leemed to be the superior authority. This is clearly set forth in the provision of the constitution which provides hat:

This constitution and the laws of the United States which shall se made in pursuance thereof; and all treaties made, or which 
shall be made, under the authority of the United States, shall be the supreme law of the land, and the judges in every state shall be bound thereby, anything in the constitution or laws of any state to the contrary notwithstanding. (Art. VI, p. 2.)

It is unnecessary for us to dwell upon the importance of this provision. It means, not only that the central government shall be deemed to be the superior political authority; that its laws, if within the powers granted to it, shall prevail; but that the decision of all disputes regarding the respective jurisdiction and powers of the two governments shall rest with it, this decision being made by its judiciary.

Another feature in respect to which one government may be dependent upon another is where provision is made that action by one government can be taken in respect to certain matters, only after the approval of the other government has been obtained. This feature exists only to a very limited extent in the governmental system of the United States. The only cases in which it exists are those covered by the following provisions of the federal constitution:

No state shall, without the consent of Congress, lay any imposts or duties on imports or exports, except what may be absolutely necessary for executing its inspection laws; and the net produce of all duties and imposts, laid by any state on imports or exports, shall be for the use of the Treasury of the United States; and all such laws shall be subject to the revision and control of the Congress. (Art. I, Sec. Io, p. 2.)

No state shall, without the consent of Congress, lay any duty of tonnage, keep trops, or ships of war in time of peace, enter into any agreement or compact with another State, or with a foreign power, or engage in war, unless actually invaded or in such imminent dangers as will not ad.ait of delay. (Art. I, Sec. Io, p. 3.)

These two paragraphs were inserted in the constitution as a part of the provisions having for their purpose the speci- 
fication of the jurisdiction of the state governments. In practice they have acted almost as prohibitions, since little or no attempt has ever been made by the states to secure the approval of the central government and the taking of the action covered by them. As far as practical results are concerned, they might almost as well have been made absolute prohibitions in so far as state action is concerned. No case exists where action by the central government is dependent upon the securing f $_{\text {f }}$ the approval of the state governments, except in respect to the matters of constitutional amendments as above described.

Still another way in which a central and state government may maintain relations with each other is through the right which one government may have to call upon, or receive, the assistance of the other government. The only provision for action of this kind contained in the federal constitution is that contained in the section which provides that:

The United States shall guarantee to every state in this union a republican form of government and shall profect each of them against invasion; and on application of the legislature, or of the executive (when the legislature cannot be convened) against domestic violence. (Art. IV, Sec. 4.)

This means that upon the central government falls the ultimate responsibility for maintaining intact the general governmental system created by the adoption of the constitution of the United States.

Turning now to the field of administration we find two directly opposite systems open for adoption by Multiple Governments. The one is where, as far as circumstances will permit, duplication of officers is avoided by the central government making use of the officers of the constituent 
states or vice versa. The other is where each government is provided with its own independent set of officials. The first of these two systems is the one which has been adopted by Germany, the second the one adopted by the United States.

In Germany, though the central government has its own distinct sphere of activities, use is, as far as possible, made of officials of the constituent states for the actual conduct of its affairs. Thus, though the central government establishes a system of customs dues which is uniform for the whole empire and the income from which is covered into the central treasury, the actual collection of these dues is made by officials of the states. The only purely central officials are those which are required to supervise and control the administration of this system. The same is true of almost all other branches of the government service, not even excepting the military establishments. Each state maintains its own army. These are united in a force available for a common use in a war of offense or defense only through stringent provisions regarding the obligation of each state to maintain its army at a certain standard of strength through the authoritative powers by the central government to prescribe the scheme of organization, equipment, etc., and through the possession by the central government of general powers of direction and command in the case of war.

The only notable exception to this policy of making use of state officials for federal purposes exists in the case of the navy. The navy, unlike the army, is a purely federal service. Its officers and men from the lowest seamen to the officers highest in command are purely federal officers.

The same policy has been pursued in the organization of the judicial system. Instead of two independent judicial 
establishments, Germany has but one set of courts in which are tried all cases whether arising under laws of the Empire or of the several states. All of these courts are, with the exception of the superior provincial courts and the supreme court, state tribunals. Under the German system, therefore, the administrative system of the central government and the states are as far as possible integrated into a single system.

In the United States no such effort has been made to have a single set of officials serve as agents for carrying into effect the wishes of the two governments. The central government and the state governments maintain absolutely independent services for all purposes. This means a complete duplication of authorities for the performance of all of the general functions of government and a corresponding duplication in respect to the performance of those special functions which are performed by both. The central government and each of the governments of the states maintains its own services for the collection of its revenue and its disbursements. Where operations are carried on in the same field, as, for example, in that of the promotion of education, the regulation of means of communication, the development of the natural resources of the country, each acts independently of the other and through its own officers.

The most striking example of this duplication of organization is furnished by the system of courts of the country. There is no reason why the adjudication of all laws, federal and state, should not be entrusted to a single system of courts. This system might be entirely a federal one or one partly federal and partly state as is the case in the German system of courts. Under the latter plan all inferior courts, or those whose territorial jurisdiction did not 
extend beyond the boundaries of a single state, would be state courts and all superior courts, or those whose territorial jurisdiction extended over the territory of more than one state, would be federal courts. Instead of any such arrangement, the two governments maintain absolutely independent judicial establishments, each with its own judges, marshals or sheriffs, clerks, deputies, etc.

It is hardly necessary to point out that this policy of maintaining completely independent services for all purposes leads to a great duplication of plant and organization. Two offices are maintained at many points where one would suffice. That it is quite feasible for the same officer to serve in more than one capacity is amply demonstrated by the fact that it is a common practice for the states to make a large use of local officials in the collection of their revenues and in the performance of other duties.

Were the fields of activities of the central government and the states distinct, this duplication of organization would not be such an important matter. Such, however, is not the case. We need only cite such matters as the regulation of rates and conditions of service of railway and other transportation corporations; the enforcement of pure food and genuine label laws; the promotion of education; the investigation of the natural resources of the country through geological and other surveys; the fostering of agriculture through research and experiment stations; the regulation of banking, insurance, etc., to show to how large an extent the two governments are working in the same fields.

What makes the matter all the more serious is the fact that no effective means exist through which like services of the two governments may be brought to work in cooperation or even harmony with each other. The best that can be done is for officials working in the same field to form 
purely voluntary associations in which their common problems will be discussed and as far as possible agreement reached to adopt the same lines of action or methods of procedure. Of this character are the national associations of railway commissioners, banking and insurance commissioners, factory and mine inspectors, chiefs of bureaus of labor statistics and the like. In a few cases important work has been accomplished by these organizations but as a whole the results are relatively unimportant. Much, for a time, was hoped of the Annual Conferences of Governors of the States. The results of these meetings, however, have been exceedingly rneager.

In large degree the duplication of organization, plant and work is, as we have previously pointed out, a consequence of the adoption of the federal type of government. There is, however, no necessity that it should be carried to the extreme extent that it has in the governmental system of the United States.

Relations of the States Among Themselves.- The government of each state is thus not only almost completely independent of the central government but of that of any of its sister states. No provision is made for their acting jointly in respect to matters of common interest. On the contrary they are expressly prohibited from entering into any agreement with each other except with the approval of Congress (Art. I, Sec. IO, p. 3). Provision is made, however, that the states shall act in harmony in respect to the recognition of the acts of other states, in the surrender of criminals fleeing from other states, etc. The provisions of the constitution governing these matters are as follows:

Full faith and credit shall be given in each state to the public acts, records and judicial proceedings of any other state. And the Congress may by general laws prescribe the manner in which such 
acts, records and proceedings shall be proved and the effect thereof. The citizens of each state shall be entitled to the privileges and immunities of citizens in the several states.

A person charged in any state with treason, felony, or other crimes who shall flee from justice and be found in another state, shall, on the demand of the executive authority of the state from which he fled, be delivered up to be removed to the state having jurisdiction of the crime. (Art. IV, Sec. I, 2 and 3.)

\section{The Division of the Territory of a State into Major} Political Divisions.- Another problem that is presented in making a territorial distribution of the powers of government consists in the determination of the number and boundaries of the major political subdivisions for which provision will be made. The disadvantages inherent in a Multiple Government would be greatly minimized if this determination were had strictly in accordance with governmental needs. Unfortunately this consideration is rarely made the determining factor. Only in exceptional cases is the primary division of a country into grand political divisions a matter of deliberate action. In almost all cases this division has been the result of historical accident. In many cases these subdivisions were originally independent kingdoms or commonwealths. This is true of the constituent states of the German Empire, the provinces of Spain, the original thirteen states of the American Republic, the four grand divisions of Great Britain - England, Wales, Scotland and Ireland - and indeed of many of their subdivisions now known as counties, and most if not all of the cantons of Switzerland. France is almost the only State of first rank where the attempt has been made to effect the primary subdivision of the territory by deliberate act, though this of course is the means through which all but the original states of the American Union have been brought into existence. This fact is one of great im- 
portance and profoundly affects the problems of dividing the territory of modern States for governmental purposes. It means that this division has not been made, nor is it likely in the immediate future to be made, in response to the real political needs of the country. The controlling factor has been and, for a long time will undoubtedly continue to be, sentiment, regard for historical traditions, rather than actual expediency.

Division of the United States into States. - It might seem that the United States, with its relatively short national existence, and composed as it is of commonwealths for the most part having few or no historical traditions as independent States would be comparatively free from the influence of historical sentiment. Such, however, is not the case. Where such sentiment has been absent, it has been deliberately created. It is thus as true of the United States as of any other country in the world that the division of the country into major political divisions has not been made in accordance with the real governmental needs of the country.

This cannot but be counted as a defect in our political system. Hopeless as may be the chances of correcting this defect at an early date, it is none the less remarkable that it has not received more attention. It must be apparent that the division of the country into states is a purely arbitrary one. What is the difference, for example, in the interests of North and South Carolina, of North and South Dakota, or for that matter between many other adjacent states, that calls for their separation and the consequent existence of two completely separate organizations for the management of their governmental affairs? The further fact that the constituent states vary so greatly in their areas and populations has made the federal system more difficult of opera- 
tion, and has been productive of no compensating advantages.

It is of interest to consider the manner in which we should proceed to effect the primary political subdivision of our country and the character of the system that would result were we to proceed upon the basis of devising a system that would correspond to our governmental needs. Our method of procedure would evidently be that of determining, by a study of conditions, the extent to, and manner in, which the country is actually divided into areas having a special character and consequently special governmental interests. Should we do this we would find that the United States embraces not to exceed ten or fifteen areas having characters and interests sufficiently diverse to warrant their being created into political divisions having the status of our constituent states. There would of course be room for considerable differences of opinion regarding the precise number and boundaries of these areas. In general, however, they would correspond to the divisions of the country into sections that have been made by the Federal Census Bureau in order that an effective presentation might be made of its statistics of population, agriculture, manufactures, etc. But a slight familiarity with conditions in the United States is required to show how closely this division corresponds to actual conditions and needs. A properly devised system of primary political divisions should as far as possible meet two requirements. The districts provided for should be sufficiently unlike as regards the character of their conditions and problems to warrant their creation into areas having independent political authority and organization, and individually should be sufficiently homogeneous to make reasonably certain that the predominant interests of their inhabitants will be the same. The division of the territory 
of the United States made by the Census Bureau meets both of these requirements. In the New England Division we have a section of the country that is densely populated, includes a large number of cities of the first and second rank, most of which are important sea ports, and is largely given over to manufacturing, commercial and transportation operations. Its governmental problems are those attaching to a thickly settled, predominantly urban and intensely manufacturing and commercial community, and are manifestly largely identical for all of the states included within it. In the South Eastern and South Central Divisions we have sections which are, comparatively speaking, thinly populated, are not only largely given over to agriculture but agriculture of a quite special character. In these divisions, moreover, are included the great bulk of the negro population of the country. To a very considerable extent, therefore, these divisions not only have interests dissimilar from those of other sections, but ones which are fairly uniform throughout these respective areas. In the Central Divisions, embracing the great Mississippi Basin, we have regions of a mixed agricultural and manufacturing character but with the former predominating. In the Mountain Districts the predominant interests are those of mining and cattle raising. All the states included are relatively thinly populated, and include few cities of first rank. They are alike also in having an inadequate rainfall, with the result that recourse has to be had to irrigation if sufficient water is to be secured for the prosecution of agriculture. Its governmental problems largely have to do with the regulation of mining, the taking up and settlement of land and the promotion and control of irrigation projects. The Pacific District is one corresponding in general to that of the North Eastern Districts but has its special problems arising from its geo- 


\section{THE GOVERNMENT OF MODERN STATES}

graphic situation, the inclusion within its population of large numbers of the yellow races and the newness of its development.

It cannot but be apparent that, judged solely from the standpoint of governmental needs, a division of the country into a few grand divisions such as these would furnish a scheme of primary political divisions far superior to that of the one we now have. In each such grand division we would have instead of six, eight, or ten separate governmental organizations attempting independently to solve problems in respect to which the interest of all are largely identical, a single strong organization. In place of six, eight or ten, railway commissions, banking commissions, insurance commissions, etc., we would have a single railway, banking or insurance commission. Not only would the cost of maintaining these services be thereby greatly diminished but the industries regulated would be relieved from the great burdens to which they are now subjected by having to meet the requirement of a number of independent authorities. 


\section{CHAPTER XI}

THE DISTRIBUTION OF GOVERNMENTAL POWERS FUNCTIONALLY

The spliting up of the territory of a State into political divisions and the distribution of governmental powers among such divisions constitutes but one method by which provision may be made for the effective exercise of these powers. The work that has to be done by a government is so complex that it is imperative that special organs shall be established for the performance of the several kinds of work to be done. This is necessary, not only that the benefits of specialization may be secured, but that responsibility may be more definitely located. It follows, therefore, that all governments must seek to determine the classes into which governmental powers fall, viewed from the standpoint of their character, and the provision that shall be made for the exercise of each.

Analysis of the Problem.- An analysis of this, problem shows that it, like that of the distribution of governmental powers territorially, involves a number of distinct factors. The more important of these are: (i) the manner in which governmental powers shall be classified for purposes of distribution; (2) the extent to which each class of work or function so distinguished shall be assigned to a separate organ or branch; (3) the relations that shall be established among these several branches; and (4) the authority by which this classification and distribution of governmental functions shall be effected. 
The Classification of Governmental Powers.- In seeking to classify any body of data the first essential is the adoption of the principle or basis upon which such classification shall be made. In making a selection of a principle it is furthermore desirable that the choice should fall upon some characteristic which is at once fundamental rather than incidental, and will serve to bring out distinctions which will best serve the objects in view. In the present case no doubt exists regarding the principle that should be employed. A distinguishing feature of the modern government in its practical operations is that it is one of law. Every feature of its organization is a matter of legal determination, and every one of its acts, in order to possess validity, must rest upon a legal sanction. The practical problem of organizing and conducting a government is thus one of legal action. It resolves itself into the problem of determining how the law of the land, and particularly that part having to do with the operations of government, shall be declared, how differences of opinion regarding its meaning or applicability to particular cases shall be decided, and how the law as thus declared and interpreted shall be put into effect. The principle upon which governmental powers should be classified functionally is thus universally recognized as that of the nature of the power exercised as determined by its relation to law.

The Traditional Threefold Classification of Governmental Powers into Legislative, Judicial and Executive. - Based upon this principle of classification, all the powers of government have long been conceived as falling within one or the other of three great classes, according as they have to do with: (I) the determination or enactment of law; (2) the interpretation of this law; and (3) its enforcement. To these three classes have been given the 
names, legislative, judicial, and executive. Structurally considered, government has thus been deemed to be made up of three great branches having for their functions the enactment, the adjudication and the enforcement of law.

A More Satisfactory Classification that of a Fivefold Division of Powers into: Electoral, Legislative, Judicial, Executive and Administrative.- Notwithstanding the fact that this threefold division of governmental powers has received such general recognition as to give it the designation of the classical division of governmental powers, examination will show that it cannot stand the test of scientific analysis, and, furthermore, that attempts to act upon it not only lead to confusion of thought, but to serious difficulties in working out the practical problems of the distribution of governmental powers functionally. The defect in this system of classification lies in the fact that it fails to distinguish and make separate provision for the functions of electoral action and administration. In the pages that follow it will.be seen how distinct these functions are from the other functions comprehended within the threefold classification and how important it is that their distinct character should be recognized in the practical work of organizing and operating a government.

The Electorate as a Distinct Branch of Government. - At the time that the threefold classification of governmental powers into legislative, judicial and executive established itself the leading nations of the world were Monarchies. Electorates, in the modern sense, were either nonexistent, or played such a minor rôle in the determination of how the actual affairs of government should be conducted, that students of politics were justified in ignoring them. With the rise of Popular Government the whole problem of government has undergone a radical transformation. 
The source of authority has been transferred from the ruler to the people. The latter have been compelled to organize themselves for the exercise of this authority. They have done so by making a selection of those of its members who shall act for them. These members constitute what is known as the Electorate, that is, the body of citizens exercising voting or electoral powers.

This body it need hardly be pointed out constitutes, not only a distinct branch of the political system of a country, but has clearly distinguishable and definite functions. Its existence gives rise to many distinct problems: how it shall be constituted, what shall be its powers and duties, what its methods of procedure, what its relations to the other branches of government, etc. The issue between Democracy and Representative Government is distinctly a problem of this branch. It follows, therefore, that the existence of this branch as a distinct branch of government should be recognized and the problems connected with it be given independent consideration.

In doing this two positions may be taken. The electorate may be looked upon as an integral part of the machinery of government or as standing outside of the government, strictly speaking. In a government of a purely representative character there is some advantage in taking the latter position. When, however, the electorate, as in the United States, seeks to take to itself the performance of certain purely governmental functions, such as the formulation of governmental policies and programs and participation in the actual work of legislation through the devices of the "Initiative" and the "Referendum," it is probably better to consider it as a branch of the government proper. In practice the choice between these two positions is of relatively little importance. The important thing is to recog- 
nize that, in the electorate, we have to deal with a distinct branch of the political systems of modern States, and one which gives rise to problems as difficult of solution as those presented by any other branch.

\section{Administration as a District Branch of Government.}

- In the threefold classification of governmental powers no recognition is given to Administration as a separate function or branch of government. In so far as any account at all is taken of this function in that classification, it is confused with, and treated as a part of, the executive function. To so great an extent is this true that the two terms "executive" and "administrative" are used almost interchangeably. This is exceedingly unfortunate since, as we shall see, the two terms should be employed as connoting operations which are distinct in character.

To understand the difference between the two, when properly employed, it is necessary to distinguish between two things. The first of these is the difference between the function of seeing that laws are enforced and that of actually doing the things which the laws call for. This distinction is specially apparent where the actual exercise of authority is distributed among a number of organs or parts. Where this is the case it is evident that there must be some authority whose special function it is to see that the laws governing this distribution, determining the special duties of the several parts and regulating the relations of the latter with each other are in fact complied with. Without some such authority the several parts cannot be correlated into a single harmonious system and made to work in proper cooperation with each other for the attainment of a common end.

The second distinction is that between the act of an organization as a whole, and that of one of its parts. There are many cases where governmental action should represent 
the action of the government as a unit. This applies especially to the whole field of international relations in which is involved the intercourse of sovereign States with each other. This makes it imperative that there shall be some organ or authority whose special function it is to represent the government in this capacity.

With these distinctions and requirements in mind, the essential difference that exists between the executive and the administrative function, using these terms in their proper technical sense, can be seen. The executive function is the function of representing the government as a whole, and of seeing that all of its laws are complied with by its several parts. The administrative function is the function of actually administering the law as declared by the legislative and interpreted by the judicial branches of the government. This distinction is usually made by declaring the executive function to be essentially political in character; that is, one having to do with the determination of general policies, and involving the exercise of judgment in its use; and the administrative function to be one concerned with the putting into effect of policies as determined by other organs. Thus A'ucoc, the eminent French authority on public law, differentiates the two as follows: ${ }^{1}$

When we distinguish government (i.e., executive direction) from administration, we mean to put in a special category the direction of all affairs which are regarded as political; that is to say, the relation of the chief executive authority with the great powers of government, the summoning of electors for the election of senators and representatives, the closing of the session, the convening of the chamber of deputies and of the senate, the closing of the senate, the dissolution of the chamber of deputies, the carrying

1 "Conferences sur L'administration," etc. Quoted by Goodnow,"Principles of Administrative Law of the United States." 
on of diplomatic relations with foreign powers, the disposition of the military forces, the exercise of the right of pardon, the granting of the titles of nobility.

\section{The Question of the Union or Separation of Powers.}

- Too great importance cannot be attached to the foregoing analysis of the powers of government. The fact that all the work involved in the conduct of a government falls into these five clearly distinguishable categories detarmines the whole nature of the problem of devising an organization through which they may be exercised. From the structural side the work of organizing a government resolves itself into that of determining the provision that shall be made for the exercise of each of these powers.

In our examination of the problem of the territorial distribution of powers we have seen how the constituent authority is called upon to make the vital decision as to whether it will confer all the powers of government upon a single government, leaving to that government the duty of distributing the actual exercise of these powers between itself and subordinate political divisions; or will itself make such a distribution; and that according as it decides one way or the other, it brings into existence, a Unitary or a Multiple Government. Precisely an analogous decision has to be made by it regarding the question of the provision that shall be made for the exercise of the five great classes of governmental powers. It must decide whether it will vest full authority in respect to the exercise of all of the powers that are conferred upon the government proper in a single organ, leaving to that organ the duty of making such a distribution of these powers to special organs to be created by it as it deems proper, or whether it will itself make this distribution. If it decides to do the first, it brings into 
existence a government known as a Government of Union of Powers; if the second, a Government of Separation of Powers.

Of governments of the first class that of Great Britain offers the best, if not the only, example where this principle of concentrating all authority in the first instance in a single organ of government has been carried out without any qualification or exceptions. In this government all governmental authority rests primarily in Parliament. All the other organs of government are created, and their jurisdictions, powers, and procedures determined by it. To this class of governments also belong of course those where all authority is vested in the hands of a single autocratic ruler. The government that is established by a military commander for the civil government of territory occupied by him is also of this character.

The governments of most other modern states belong to the second class. Great differences, however, exist between these governments in respect to the extent to which the attempt has been made by the constituent authority to provide for the exercise of the several powers by coordinate organs or departments of government. Among these governments that of the United States represents the attempt to carry the principle of separation of powers to its greatest possible extent. As regards this fundamental feature of government we thus find Great Britain and the United States standing at opposite extremes. It is in the comparison of these two governments that one can thus best see the results following from the adoption of one or the other of the two policies in respect to the union or separation of powers.

There are few topics in political science about which more has been written than that of the separation of pqwers 
which we now have under consideration. Notwithstanding this there are few subjects regarding which greater misconception exists. The reason for this is that there is a general failure to distinguish between certain important questions that are involved in it. The fact of the matter is that the subject is an exceedingly difficult one and only by the most painstaking study can one hope to understand it in all of its phases.

Status of Organs Exercising the Several Powers in the Two Types of Government - Those of Union of Powers and Separation of Powers.- In seeking to make a study of this character, the first point to be noted is that, as in the case of the distribution of powers territorially, the issue is, not as to whether special organs shall be provided for the exercise of the several powers of government, for such organs are found in all modern governments, but as to the authority by which such organs shall be established, their powers defined and their relations to each other determined. In a Government of Union of Powers the authority doing this is the organ of government to which all the powers of government have in the first instance been given by the constituent authority. In a Government of Separation of Powers this is the constituent authority itself. Herein lies the distinction between these two types of government. From the structural side there is little or no difference since in both governments separate organs have been provided for the exercise of the several powers. The only difference between them is in respect to the constitutional or legal status of these organs. In a Government of a Union of Powers one organ, which, in practice, is the legislative branch of the government, is supreme; the other organs are but its agents, the means through which it exercises those of its powers which it does not desire itself 
directly to exercise. In a Government of Separation of - Powers the several organs or branches of government, in so far as they have been established and their powers defined by the constituent authority, are coordinate in rank: the line of authority in each case runs directly to a common authority, the constituent authority.

Distinction Between a Personal and an Organic Union or Separation of Powers. - The foregoing distinction is one which, though not often explicitly stated in discussions regarding the union or separation of powers, is nevertheless one generally understood by students of political science. We come now, however, to a distinction which, though it goes to the very heart of the whole question, is yet one which has received little or no attention. The failure to make this distinction, and to appreciate the consequences flowing from it, more than anything else is responsible for the vast amount of misconception that exists in respect to the relative merits and consequences of the two systems.

This distinction is that between the separation of powers which is secured when the exercise of the several powers is vested in distinct organs, each of which is manned by a distinct set of officials, and that resulting where use is made of separate organs, but these organs are, in part at least, in charge of the same persons. This distinction, it is evident, is the same which exists between the two cases where two industrial undertakings are carried on by separate corporations, no officer of which is an officer of both corporations, and where use is made of two distinct corporations, the officers of which are composed in whole or in part of the same persons. In both cases the separation is organic. Only in the first case, however, is it a personal one. We can distinguish between the two, therefore, by designating 
the first as a personal and the latter as an organic separation of powers.

The English Government One of Separation of Powers Organically and Union of Powers Personally. - The importance of this distinction can be seen when we attempt to compare the governments of Great Britain and the United States from this standpoint. The former government is usually regarded as the most striking example of a government of united powers, the latter as an equally prominent example of one with a separation of powers. The undoubtedly greater smoothness and efficiency with which the former government works, in comparison with the latter, is believed to find its chief explanation in this fact that, in the former, there is a union, and in the latter, a separation of powers.

With the belief that the government of Great Britain does work in a smoother and more efficient manner than that of the United States, and that the reason for this is in great part found in the difference between the two governments as regards this feature of the union or separation of powers, the author is in entire accord. The explanation of the superior results given by the former, is, however, in the opinion of the author, precisely the opposite of that which is usually alleged as accounting for this fact. The excellence of the British government, and the poorness of the American government does not lie in the fact that, in the former, there is a union and, in the latter, a separation of powers, but in the precise reverse of this; namely, in the extent to which that principle of vesting the exercise of each power in a distinct organ is adhered to in the former, and disregarded in the latter.

A close study of the English government, in its practical workings, shows that, organically, the principle of the 
separation of powers has been carried out with a rigidity that is found in few or no other governments. After a long struggle between the Parliament and the Crown the latter was shorn of all of its legislative powers and the exercise of this power was vested wholly in the former. On the other hand Parliament, though victorious in the contest with the Crown, has never attempted to deprive the latter of any of its executive powers, nor itself to participate in any way in the exercise of that power. More remarkable still, Parliament has never taken to itself the function of administration. This is strikingly illustrated in its attitude towards the budget, that is, towards the determination of the manner in which the revenues of the country shall be raised and expended. The formulation of the annual budget of receipts and expenditures is recognized as essentially an act of administration. By a self-denying ordinance, or rule, it has provided that no measure looking to the raising of revenue or the expenditure of funds shall even be considered by it, except such as are brought before it and recommended by the ministry of the day, which, in their capacity as heads of the administrative departments, constitute the administrative branch of the government. More than this, it denies to itself the right to modify the proposals so brought before them in any respect, except as such modification may meet with the approval of the latter. In point of fact, the budget which constitutes the whole financial program of the government for the year is determined absolutely by the administrative branch of the government. The only real participation in this act by Parliament is the right which it has that the budget, as framed, shall be laid before it for its information, and that it shall have an opportunity to express its opinion regarding it. There is here no division of power or responsibility. Power 
in respect to, and full responsibility for, the budget rests with the administration. ${ }^{1}$

We have mentioned specially this matter of the enactment of the budget since it constitutes, not only the most important and vital of all administrative acts, but because the attitude that Parliament takes towards it is typical of its attitude towards all matters of administration. No effort is made by it to substitute its judgment for that of administrative officials in the actual administration of affairs. In not a single case does it, for example, require that the appointment of officials, high or low, shall come before it for approval or disapproval. Any such provision would be deemed to be a grave trespass of the legislative branch upon the field of administration.

In like manner the judiciary has been established as a distinct and independent branch of the government. This has been accomplished by the enactment of laws requiring that all appointments to high judicial office shall be during good behavior, that the salaries of judges shall constitute a permanent charge upon the consolidated fund, and thus be independent of any annual budgetary provision, and that the judges themselves shall only be removed upon an address on the part of both houses of Parliament requesting that this be done.

If we turn from a consideration of the union or separation of powers organically to that of their union or separation personally, we find quite a different condition of affairs. Though distinct organs are provided for the exercise of each of the great powers of government, these organs are, as

1 For a full consideration of this feature of the English government, see: "The System of Financial Administration of Great Britain," by W. F. Willoughby, W. W. Willoughby and S. M. Lindsay, "Studies in Administration, Institute for Government Research," D. Appleton \& Co., 1917. 
regards their superior officers at least, under the direction of the same persons. We have in effect the same situation as that which exists when the same persons are officers of distinct corporations, each with its distinct field of activities, but all having for their object the attainment of a common end.

This situation of affairs can only be understood by appreciating that the ministry, or the cabinet, though possessed of unity as far as its personnel is concerned, acts as three distinct organs. In their capacity as members of Parliament, the members of the ministry act as a committee on rules and program of that body. As heads of administrative departments they act as a central administrative board. As the actual custodians of the powers of the Crown, they act as the chief executive of the nation.

This distinction between the three capacities in which the ministry acts is not a mere theoretical one for the purpose of making clear the functions of this body. It is one which is strictly observed in practice. In the ministry we have. three distinct organs. When acting as an executive organ it acts independently of Parliament and as the direct representative of the Crown of whose original power it is now the custodian. When acting as a legislative organ it keeps strictly within the legislative field and does not seek to take to itself either executive or administrative functions. When acting as an administrative board it does not seek to exercise either executive or legislative powers but confines itself strictly to the problem of administration.

To sum up then, the prime characteristics of the British governmental system, from the standpoint of the union or separation of powers, lie in the definite separation of powers organically, and their close union, personally. Each 
organ confines itself to the work which belongs to itself. At the same time there is full recognition of the fact that the several branches of government are but parts of one piece of mechanism and that as such their operations should be conducted in accordance with general policies and directed to a common end. This is secured by placing the same persons in charge of these several organs.

It is in this harmonizing of these two apparently conflicting considerations, the distinct separation of powers organically and their union personally, that lies the great merit of the British governmental system. The bald statement that the excellence of this system lies in the union of powers is thus, not only misleading, but wholly erroneous, since it implies that this union is not merely a personal but an organic one, an implication which as we have seen is directly contrary to the fact. The real explanation of the excellence of the system lies, as much, if not more, in the separation of powers organically as it does in their union personally.

\section{The United States Government One of Union of Pow-} ers Organically and Separation of Powers Personally. - If the Government of Great Britain is looked upon as the most prominent example of one with a union of powers, that of the United States is regarded as a no less striking illustration of the contrary principle. No idea is more firmly held by the mass of the American people than that the most fundamental principle upon which their government is based is that of a separation of powers. It is in this separation of powers which they believe to exist that they find the greatest guarantee of their political liberties and safeguard against a despotic use of power by public officials. To this characteristic, on the other hand, is attributed many, if not most, of the evils which our system 
of government presents in actual operation; and in the doing away with this separation of powers is believed to lie the only effective remedy against such evils.

Deep-rooted as are these opinions regarding our government, examination will show that they are almost wholly unfounded. The government of the United States, instead of being one of separated powers, is one in which there exists a union of powers both organically and personally, to an extent that is found in few, if any, other governments of the first rank; and the troubles which are experienced in operating this system, instead of being the consequence of a separation of powers are due to the precisely opposite reason, namely, a union of the exercise of the same power in two or more authorities or organs.

The fact of the matter is that our government represents one in which, neither the theory of the union of powers, nor that of a separation of powers, has been consistently carried out. In framing our constitution its authors proceeded upon the theory that all of the powers of government were divisible into the three great branches of legislative, judicial and executive and that separate provision should be made for each. They failed utterly to recognize or to make any direct provision for the exercise of administrative powers. In ,consequence of this failure our entire constitutional history has been marked by a struggle between the legislative and the executive branches as to the relative parts that they should play in the exercise of this power: This is a matter to which we will give special attention in another place.

Disregarding this point for the present, we find that the framers of the constitution, in acting upon this theory that the powers of government fall into the three classes of legislative, judicial and executive, proceeded to provide for 
three organs, a Congress, a Judiciary and a President which should constitute the three branches, or departments, of government corresponding to these three powers. Having made provision for these separate organs they, however, refused to vest in them the exclusive exercise of the powers to which they corresponded. On the contrary they so defined the powers of each and so distributed the exercise of the three powers among them that no one can act independently in its own field. In almost all vital matters the concurrence of one or more of the other two organs is required. A rapid survey of some of the more important provisions of our constitution bearing upon the exercise of the three powers will show to how great an extent this is true.

Though the first section of the constitution provides that " all legislative powers herein granted shall be vested in a Congress of the United States which shall consist of a Senate and a House of Representatives," active participation in the exercise of this power is in fact conferred upon the executive branch by the requirement that no bill shall become a law until it is referred to the President for his approval and the power that is granted to the latter to veto such bills as do not meet with his approval. It is true that such veto may be overridden if a two-thirds majority vote for such action can be secured in both houses. This, however, does not remove the fact that the Executive is given an active participation in the exercise of the legislative power and that this participation, in the great majority of cases, determines whether a given measure shall, or shall not, become a law. In this connection it is important to note that this veto power of the President, though negative in form, can be and is used to influence legislation in a positive way. This is done by the President letting it be known that if certain provisions are omitted from, or allowed to con- 
tinue in, a measure it will receive his veto. In considering measures, Congress has constantly to bear in mind this contingency of a Presidential veto. Through the possession of this power the President thus exercises a very positive influence in determining the character of the laws that are drafted by Congress and sent to him for his approval.-

This power to veto bills represents, moreover, but one of the ways in which the President participates actively in the exercise of the legislative power. The provision of the constitution that the President " shall from time to time give to the Congress information of the state of the Union and recommend to their consideration such measures as he shall judge necessary and expedient" has been interpreted as conferring upon the President not only the authority, but the obligation, to propose legislation. In the early days of the Republic it was believed that the President had exhausted his authority under this grant when he had brought to the attention of Congress action which in his opinion should be taken: responsibility for taking action upon these recommendations was deemed to rest wholly with Congress. Within recent years, however, a radical change of attitude towards this function has taken place. The people now look to the President, not only to formulate a definite legislative program but to exert all his influence and power to secure favorable action upon it. A few years ago Congress would have resented the attempt on the part of a President to embody his proposals in the form of definite drafts of bills as an infringement of its function. Now the President boldly puts his proposals in this form, declares them to be administrative measures, and takes the position that support of them is a test of party fealty.

The President moreover does not stop with this formulation of a legislative program. He thereafter exerts himself 
to the utmost to secure favorable action upon his proposals. $\mathrm{He}$ is in constant consultation with the leaders of his party in Congress. By personal interview and other means he seeks to overcome the opposition of members not favorably disposed. If need be he uses the great powers which he possesses to bring pressure to bear upon individual members to support his measures. Patronage can be liberally bestowed or wholly withdrawn, special action desired by members can be supported or opposed. In extreme cases the fight can be carried into a member's district and his renomination or reelection to office can be supported or antagonized according to the position taken by him in relation to administrative measures. The extent to which such a use of power by a President to coerce a member of Congress in the exercise of his function as a legislator is legitimate raises a very important question which will be elsewhere considered. Here it is only desired to bring out the extent to which the President both has and uses the power to influence legislation and thus to make of himself one of the distinct organs through which the legislative function is performed. There can be little doubt that this increased participation on the part of the President in the field of legislation meets with popular approval.

The same demand that the Chief Executive shall formulate and seek to secure action upon a legislative program is equally evident in the administration of the affairs of the individual states. The assumption of this important function in relation to legislation by the Chief Executive, both of the federal government and of the constituent states, thus bids fair to harden into one of the firmly established conventions of our constitutional system. In virtue of this convention and the existence of the veto power by the President it is thus not going too far to say that the Presi- 
dent now constitutes an organ of legislation scarcely second in power and importance to Congress itself. ${ }^{1}$

The Chief Executive is not the only organ, however, with which Congress has to share the legislative function. It has now become firmly established that upon the courts falls the function of determining whether the several branches of government in the exercise of their powers have kept within the limitations imposed upon them by the constitution through which they were established and their powers defined. Attention has already been called to the fact that one of the serious consequences of the attempt to define by constitutional enactment the extent of governmental powers and the manner in which these powers shall be distributed territorially and functionally is the establishment of a system under which many questions are bound to arise regarding the exact meaning and intent of these provisions and

${ }^{1}$ It is important to note that the position now held by the President as one of the distinct organs through which legislation is had is primarily the result of the growth of a convention. The framers of the constitution had no idea that the President should play any such part in legislative matters. It is well recognized that the veto power was conferred upon him not with a view that through it the President might influence legislation generally. It was granted to him primarily as a weapon through which he might protect himself against an encroachment upon his powers by Congress. This moreover was the manner in which the veto power was interpreted, and, with rare exceptions, acted upon, by Presidents down until the last quarter of the nineteenth century. The idea that it was proper for a President to set up his individual judgment against the collective judgment of Congress was not entertained. Now it is accepted as quite the normal thing that he should do so. In like manner there was no conception on the part of the framers of the constitution that use would be made by the President of his power to recommend action to Congress to formulate and put through if possible a general legislative program. Though the foregoing is a matter of historical interest the fact nevertheless remains that in our constitutional system as actually worked there is this large participation by the President in the exercise of the legislative power. 
their application to particular concrete cases. This renders it imperative that authority shall be vested in some organ to pass upon these questions. In the United States this power has been assumed by the courts as a part of their general duty to interpret the law of the land. The result is that all laws must finally pass the test of judicial approval if any question regarding their validity is raised.

It might seem that this power possessed by the courts to construe laws was distinctly a judicial power and in no way partook of the nature of the exercise of legislative power. Strictly speaking this is so. Two facts, however, have made the exercise of this power by the courts one profoundly affecting the exercise of the legislative power in the United States. The first of these is the fact that, in practice, the provisions of the federal and state constitutions determining the powers of government and the manner of their exercise have proven of such a character that it is almost impossible for Congress or a state legislature to depart in any way from the beaten path without giving rise to the question of the legality of their action. The result is that almost every attempt made by them to break new ground for the purpose of solving social problems has been questioned in the courts, and the latter have therefore had the final say as to whether they should prevail. The second is that, in passing upon these questions, the courts have taken the position that it is a part of their function to determine the facts to which the laws are intended to apply as well as to interpret the language of the laws themselves. For example, the legislature when it passes a law fixing the maximum number of hours of labor in a given industry does so in the belief that the conditions are such as to bring such action under the police power of the State and thus to meet any objection that may be raised that it represents an improper 


\section{THE GOVERNMENT OF MODERN STATES}

infringement of the constitutional provision that no person shall be deprived of life, liberty or property without due process of law. The courts in passing upon laws of this character have, however, assumed the power of questioning the soundness of this belief. If, in their opinion, such laws are not required for the proper protection of the individuals that may be affected by them, or the general public, they have not hesitated to declare such laws null and void, as not representing a proper exercise of the police powers and consequently as being instruments violating the constitutional provision just cited. The issue between the legislature and the courts is here one purely of fact and expediency. The propriety of the courts taking this position regarding their power is seriously questioned. This, however, is a matter into which we cannot here enter. We are concerned now merely with the fact that in our governmental system as it actually works at the present time the courts play a very large rôle in determining the character of legislation that the country shall have.

To sum up, it will thus be seen that our governmental system, instead of being one of the definite separation and segregation of power, is, so far as the exercise of the legislative power is concerned, quite the reverse that all three departments of government, the legislative, the executive and the judicial, participate in the exercise of this power. Authority and responsibility, instead of being concentrated in a single organ, are distributed among a number.

If we turn from the legislative to the executive power we find here too a failure to vest the exercise of this power wholly in one organ. It is true that the constitution provides that "the executive power shall be vested in a President of the United States." Subsequent provisions, however, provide for the participation by Congress in the ex- 
ercise of this power. The most important of these provisions are those which provide that the President shall have power to make treaties with foreign powers only by and with the advice and consent of the Senate and upon the concurrence of two-thirds of the Senators present, and that Congress and not the President shall be the authority to declare war and to provide for the calling forth of the militia.

Notwithstanding these provisions the principle of vesting the executive power in the hands of a single organ prevails to a far greater extent than it does in the case of the legislative power. The President, moreover, has been able effectivly to protect himself from encroachment upon the exercise of his executive powers. The only possible exception exists in respect to the exercise of the treaty making power. Here it is believed by many that the Senate has pushed its power to a greater extent than was originally contemplated. In this the author does not concur. It is significant that the provision granting the power to the Senate does not provide simply that treaties before becoming effective shall be approved by the Senate but that they shall be made by and with the advice and consent of the Senate. Clearly this anticipated that the Senate should be consulted throughout the work of negotiating treaties. If anything the practice on the part of Presidents of negotiating treaties without seeking the advice of the Senate and only bringing the treaties as negotiated before that body for approval or rejection represents an encroachment on the authority of the Senate as defined by the constitution.

Of the several powers, the judicial power is the one which has been most definitely concentrated in a single organ. The exercise of this power is vested solely in the judiciary - neither the legislative nor the executive can be said to 
exercise this power in any way. Notwithstanding the dependence of the judiciary upon Congress and the President as regards the determination of its organization, procedure and personnel, the judicial power itself is not distributed among two or more organs as is the case in respect to the executive, legislative and administrative power but is exclusively vested in one organ, the judiciary. The latter, moreover, enjoys a practical immunity from pressure of every sort from the other departments of government in exercising its functions. This is due, partly to the provision of the constitution that the judges shall hold office during good behavior and their compensation shall not be reduced during their terms of office; but chiefly to the tradition now firmly established that judges should exercise their judgment in an entirely independent manner. This tradition prevents the other departments from attempting to influence the judges and causes the judges to repel any such attempt should it be made. That in practice the United States has had a remarkably independent judiciary is beyond question.

It is when we turn to the provision, or rather lack of provision, that has been made for the exercise of administrative power that we find the greatest failure definitely to locate authority and responsibility in a single organ. The framers of our constitution performed their work at a time when all the powers of government were believed to fall within the three branches of legislative, judicial and executive. They had no conception of the function of administration as one of the distinct powers of government. No specific reference to this power is thus made in the constitution. More remarkable still, only an indirect reference is made to the matter of organization for the administration of governmental affairs. This is found in the pro- 
vision that the President " may require the opinion, in writing, of the principal officer in each of the executive departments upon any subject relating to the duties of their respective offices, ${ }^{1 .}$ and that the appointment of inferior officers may be vested by Congress " in the President alone, in the courts of law or in the heads of departments." 2

Owing to the fact that the President at the present time in fact exercises large administrative powers and is in appearance the head of the administrative departments the popular opinion prevails that the framers of the constitution employed the term executive as including what are now known as administrative powers and that it was their intention that the President should be the head of the administration. This is a mistake. There can be no question but that they used the term executive in its technical sense as covering only the political duties of the titular head of the nation. "It was undoubtedly intended," writes W. W. Willoughby in his "Constitutional Law of the United States," "that the President should be little more than a political chief; that is to say, one whose function should in the main consist in the performance of those political duties which are not subject to judicial control. It was quite clear that it was intended that he should not, except as to these political matters, be the administrative head of the government with general powers of directing and controlling the acts of subordinate federal administrative agents." 3

That this is the interpretation that Congress has placed upon its powers, and that it intended to act upon this interpretation is evident from the character of the provision that it has made for the organization and operation of the

1 Art. 2, Sec. 2, Pars. I and 2.

2 Art. 2, Sec. 2, Pars. I and 2.

3 W. W. Willoughby: "The Constitutional Law of the United States,"

p. 1156. 
administrative departments. It is true that in creating a department of foreign affairs (the present State Department) and a Department of War it vested in the President large powers to direct and control the operations of these departments. It did so, however, since these departments have to do almost wholly with matters affecting the exercise by the President of his executive powers. To have failed to do so would have deprived the President of the means of effectively exercising the executive powers vested in him by the constitution. When Congress came to establish the Treasury Department, however, it made this department a direct dependency of Congress. It made its head, the Secretary, directly accountable to it and not to the President. Both the language of the act and the debates in Congress show that it was the intention that the Secretary should receive his orders from Congress. This is clearly shown in the provision that the Secretary should make his annual reports to it instead of to the President. The same is true in respect to the Post Office Department. There is no indication that these officers should be deemed to be subordinates of the President and as such subject to his superior direction. Legally, therefore; the heads of departments, and in fact all officers of the government, are not subject to the direction of the President except in so far as Congress has expressly granted to the President this power of direction and control.

Congress and not the President is thus, in the intent of the constitution, the primary source of administrative power, and such it is in fact at the present day. It is the authority which determines how the government shall be organized for the performance of its administrative duties, what offices shall be provided, what compensation shall be 
paid, what shall be their specific duties, and, subject to a limitation which will be shortly mentioned, how the incumbents of these offices shall be appointed. Congress is thus the ultimate directing, supervising and controlling authority in respect to matters administrative. In a very true sense all the administrative officers of the government, including the President himself, when the performance of administrative duties has been entrusted to him, are but agents of Congress and subject to its orders and control.

This interpretation of the powers of Congress in respect to matters of administration has been fully endorsed by the Supreme Court. The leading case on this question is that of United States v. Kendall (5 Cranch C. C. 163, 272) in which was raised the question of the power of Congress and the President over the acts of the Postmaster General. In the course of its decision the Court said:

The legislature may prescribe the duties of the office at the time of its creation, or from time to time as circumstances may require. If those duties are absolute and specific and not by law made subject to the control or discretion of any superior officer, they must be performed, whether forbidden or not by any other officer. If there be no other officer who is by law specially authorized to direct how the duties are to be performed the officer whose duties are thus prescribed by law is bound to execute them according to his own judgment. That judgment cannot lawfully be controlled by any other person. ...

As the head of an executive department he (the Postmaster General) is bound, when required by the President, to give his opinion in writing upon any subject relating to the duties of his office. The President in the execution of his duty to see that the laws be faithfully executed is bound to see that the Postmaster General discharges faithfully the duties assigned to him by law; but this does not authorize him to direct how he shall discharge them. 
The Supreme Court on the case being appealed to it endorsed this opinion and in the course of its own opinion said : ${ }^{1}$

It by no means follows that every officer in every branch of that (the executive) department is under the exclusive direction of the President. ... It would be an alarming doctrine that Congress cannot impose upon any executive officer any duty they may think proper which is not repugnant to any rights secured and protected by the constitution, and in such cases the duty and responsibility grow out of and are subject to the control of the law and not to the direction of the President.

Though Congress has thus been made and, is, in fact, the primary source of administrative authority, the entire administrative power is not vested in its hands. In two important respects participation in the exercise of the administrative power has been vested in the Executive. Reference is made to the provisions of the constitution which provide that the President shall " take care that the laws be faithfully executed" and that: "he shall nominate and by and with the advice and consent of the Senate appoint ambassadors, other public ministers and consuls, judges of the Supreme Court and all other officers of the United States whose appointments are not herein otherwise provided for and which shall be established by law; but the Congress may by law vest the appointment of such inferior officers as they think proper in the President alone, in the courts of law or in the heads of departments."

The first of these provisions, it should be noted, confers no powers upon the President additional to those elsewhere specifically granted to him. It does, however, impose upon him the obligation of making use of these powers in such a way as to see that the laws are duly executed. Responsi-

${ }_{12} 2$ Peters 524, 610 Kendall v. U. S. 
bility in respect to matters of administration is thus very definitely imposed upon him. Apart from any specific duty that may be imposed upon him by Congress the President is thus made by the constitution one of the authorities through which a proper exercise of the administrative power is to be had.

It is in the second provision, however, that the President is granted the most direct participation in the exercise of the administrative power. The power of nominating and appointing the chief officers by whom the affairs of the government shall be carried on necessarily carries with it both a great responsibility and a great power to control the manner in which affairs shall actually be administered. This is especially so when it is held that the power of appointment carries with it the power of dismissal. Though the constitution failed to cover this point specifically, Congress has repeatedly sanctioned the view that the power constitutionally resides in the President to dismiss all officers which are appointed by him alone or by and with the advice and consent of the Senate. The acquiescence of the latter body is not necessary even in those cases where its approval is required for appointment. This question was thoroughly threshed out in the first Congress in connection with the framing of the law providing for the establishment of a department of foreign affairs. It was decided then that the power of dismissal should rest with the President. The chief consideration leading to the adoption of this position was that this power was essential to the proper discharge by the President of his constitutional duty of seeing that the law was properly enforced.

The position then taken has been consistently followed ever since, with the single exception of the attempt made by Congress to control the powers of President Johnson 
through the passage of the Tenure of Office Acts of 1867 and 1869. These acts were passed under exceptional circumstances as a phase of the bitter struggle between Congress and the President which culminated in the latter's attempted impeachment. They were brought before the courts for judicial determination and after the special circumstances leading to their enactment had passed away were in 1886 repealed.

The question as to what officers are covered by the expression "all other officers of the United States whose appointments are not herein otherwise provided for " as distinguished from "inferior officers" the appointment of which may be vested by Congress in the President alone, in the courts or in the heads of departments has never been judicially determined. In practice, however, the heads of departments and their major subdivisions, the bureaus, members of commissions and boards, and even the more important local officers such as collectors of customs, collectors of internal revenue and the postmasters of large cities have been treated as ones the concurrence of the Senate in the appointment of which is required. The great majority of all other administrative officers are treated as inferior officers and their appointment is vested in the President alone or in the heads of the departments.

In this connection it may be noted that this provision of the constitution regarding the appointment of officers, both superior and inferior, has been construed by the courts as denying to Congress itself all powers of appointment. This follows from the fact that specific provision is made how superior officers shall be appointed and that Congress is not included in the enumeration of authorities in whom the appointment of inferior officers may be vested. Congress 
can create and abolish offices but it cannot designate the persons to fill these offices. ${ }^{1}$

We have entered thus fully into the question of the power to appoint and dismiss administrative officers since it must be evident that the officer possessing this power, not only shares in the responsibility for the proper conduct of the administration of affairs but is in a position where he can direct and control the manner in which the administrative power shall be exercised. Not only can he, in choosing persons for appointment, make a selection of those who have opinions conforming to his own, but he can thereafter control their action by removing from office those who refuse to carry out his will. Whatever may be his lack of legal authority, actual power is thus possessed by him to direct how affairs shall be conducted. This is a power which the President has not hesitated to exercise. The most notable case of its exercise is that of the removal by President Jackson of successive Secretaries of the Treasury who refused to follow his orders regarding the removal of government deposits from the first Bank of the United States. This led to a direct issue between the President and Congress and caused the latter to pass a vote of censure upon the President for his action. The President, however, carried his point. At the present time it is rarely necessary for the President to carry his action this far. The knowledge that he has this power of removal is sufficient.

Much the most significant feature of this whole question

1 It is of interest to note that the individual states have not in all cases followed the practice of the United States in respect to the appointment and dismissal of administrative officers. In many cases an officer appointed by the Governor upon the approval of the legislature or one of its houses, can only be dismissed by the Governor upon the concurrence of the latter body being had. 
of the direction and control of administrative officers by the President lies, however, in the fact that at the present time the exercise by the President of such power is now looked upon by the country as thoroughly legitimate and is acquiesced in by both Congress and the heads of departments. It may now be said that the convention is fairly established that the wishes of the President, in so far as they are not in conflict with provisions of law, should control administrative officers in the performance of their duties.

Though the present administrative powers of the President are in large part the outgrowth of this power of removal, other causes have contributed not a little to the same end. With the growing complexity of governmental interests Congress has found it impossible to provide in advance by means of legislation the precise means that should be employed and the steps that should be taken in carrying through many important classes of governmental undertakings. More and more therefore it has pursued the policy of delegating to the President large discretionary powers in respect to the carrying out of its policies. In no small part therefore the present powers of the President in respect to administrative matters rest upon specific statutory enactments. Notable instances where this policy has been pursued by Congress are furnished by the acts providing for the construction of the Panama Canal, the first government of the Philippines, and the creation of agencies for the meeting of the many problems arising out of the present great war. In all these cases the President was given practically carte blanche to take such action in relation to these matters as he saw fit. In scores of minor matters a similar authority has been conferred upon the President.

Finally mention should be made of the fact that the 
courts, in interpreting the constitutional provisions bearing upon the powers of the President, have been exceedingly sympathetic to this development of the administrative powers of the latter. A broad construction has been given to the provisions that it is the duty of the President to see that the laws. are properly enforced. Wherever possible the authority of the President over administrative officers has been supported as necessary in order that the former might effectively discharge this duty.

Viewing conditions as they actually are, it will thus be seen that, in the United States, the exercise of the administrative power is fairly evenly distributed between the legislative and the executive branches of the government. The former possesses the entire authority to determine what work shall be undertaken, the plant and organization and personnel that shall be made use of and the procedure that shall be employed. The latter, subject to the necessity for securing the concurrence of the Senate in respect to important offices, has the determination of the persons who shall constitute this personnel, and, in consequence of this power and the other facts which we have mentioned, has a large power of direction and control over the manner in which they carry out the orders given by Congress. Both authority and responsibility for the actual conduct of governmental operations are thus divided between the two branches of government. This is strikingly evidenced in respect to that most important of all acts of administration, the preparation and enactment of the budget by which the annual revenue and expenditure needs of the government are determined. We have seen that in Great Britain the preparation and enactment of the budget rest wholly in the hands of the administrative branch of the government, that Parliament participates in this work only through the require- 
ments which exists that the budget as formulated shall be laid before it and that it shall have an opportunity to criticise its provisions. In the United States the budget, or rather the determination of the manner in which the revenue of the government shall be raised and expended, for, technically speaking, the United States has no budget, is a matter requiring the joint action of the legislative and administrative branches.

If now we seek to sum up and characterize in general terms the system of government of the United States from the standpoint of the manner in which this problem of distribution of powers functionally has been met, it will be seen that the system established, instead of being one of separation of powers, as is popularly supposed, is one of union of powers both organically and personally. It is true that special organs have been created for the exercise of legislative, executive and judicial powers and that general provisions have been incorporated in the costitution that the legislative, the executive and the judicial powers respectively shall be vested in these organs. Actually, however, as we have seen, no one of these organs is independent and supreme within its own field. Especially is this true in respect to the two branches which are most directly concerned with the actual conduct of the internal affairs of government - the legislative and the executive.

This system under which each branch in its operations is more or less subject to the control of one or both of the other two branches is one which has been aptly designated as a system of checks and balances. The explanation of the adoption of a system of this character lies in the apprehension that existed at the time of the adoption of the constitution of the danger which it was believed was inherent in any governmental system of the abuse of power by those in 
authority. One has but to read the discussions of the period to see how the framers of our constitution were dominated by the fear that either the popular branch of the government, the legislative, or the executive would so exercise its powers as to establish in effect a popular or autocratic tyranny. All governments, they believed, had to steer a difficult course between the Scylla of executive tyranny on the one hand and the Charybdis of Democracy, or mob rule as it was designated, on the other. Safety they believed could only be secured by making it possible for one branch of the government to check the other at all vital points. Due to this belief the framers of our constitution were more interested in the negative than in the positive aspects of government, or at least gave undue prominence to the former. They were more concerned in preventing abuses and forestalling possible dangers than in establishing an efficient governmental organization.

Comparison of the Systems of a Union and a Separation of Powers. - Having analyzed the problem of the functional distribution of governmental powers, and described the manner in which this problem has actually been met by the two great nations the governments of which best illustrate the different systems that may be established, it now remains for us to compare these two systems for the purpose of determining their relative advantages. In making this comparison it is necessary to bear in mind the distinctions which we have made between: first, the union or separation of powers from the constitutional standpoint, that is, from the standpoint of the constituent authority vesting all powers in the first instance in a single, or in a number of coordinate organs, and second, between the actual union or separation of powers organically and personally Thus we have seen that the government of Great Britain is 
one of a complete union of powers from the constitutional standpoint, one of a complete separation of powers from the standpoint of the actual exercise of the several powers by distinct organs, and one of a union of powers from the standpoint of the individuals having the direction of these organs; while that of the United States is one of a separation of powers from the constitutional standpoint, and one of a union of powers, both organically and personally, from the standpoint of the actual exercise of these powers.

Confining our attention, first to the two opposing systems of a constitutional union or separation of powers, we find that the system of a union of powers has all those advantages which we have seen attach to a Unitary as opposed to a Multiple Government. In the first responsibility for the conduct of all the affairs of government is definitely located in a single organ. The government resulting has thus the unity of responsibility, direction and power that constitutes the chief merit of an autocratic government when in the hands of a benevolent ruler. Joined with this advantage is that of complete flexibility, the power to change its internal organization at will and thus to make it conform to new conditions and desires as they arise. Just as a Unitary Government has it always in its power to make such a distribution of the exercise of governmental powers territorially as conditions, in its opinion, demand, so the government of a constitutional union of powers can make such a distribution of its powers functionally as in its opinion will permit of the most effective exercise of such powers. Another important feature of this system is the extent to which is avoids the difficulties of conflicts of authority and jurisdiction and the ease with which such conflicts as do arise can be adjusted. Finally, with authority thus concentrated the full 
power of the government can be promptly brought to bear upon any great emergency.

None of these advantages is present in a government of a constitutional separation of powers. Responsibility and authority are here divided among a number of organs. Each is jealous of its own power. If affairs do not go satisfactorily each seeks to throw the blame upon the others. Effective cooperation between the several organs is at all times difficult to secure. Instead of being flexible the system is characterized by extreme rigidity. No change in the distribution of authority can be made except by appeal to the constituent authority by which the distribution was originally made. In its practical operation disputes regarding the powers of the several organs are bound to arise and these disputes cannot be settled on their merits by an act of legislation but must be decided by the courts who, in reaching their decisions, are bound by the wording of the constitution. The result is that not only is the decision made by the branch of government which is not concerned with matters of policy and expediency, but the decision itself is often one which fails to conform to the needs of the case and is contrary to the wishes of the government and of the people as a whole. In all such cases the only remedy is by way of the difficult process of securing an amendment to the constitution. Finally, the government finds itself unable promptly to bring to bear all of its powers for the meeting of grave crises. If unity of action at all can be secured it is secured with difficulty and with unavoidable delay. In the case of the United States, only by giving to the so-called war powers of the President the broadest sort of construction has it been possible for that government to meet even in a measurable degree the exigencies of a great war. 
When the crisis is one not involving the use of military force, this resource is not available. The government of a constitutional union of powers, in a word, can meet emergencies as they arise with its hands free; the government of a constitutional separation of powers must meet them with its hands more or less shackled.

With the intrinsic advantages so wholly in favor of the constitutional union of powers, one must, as in the case of the adoption of the multiple form of government seek for an explanation of the fact that so many States have adopted the less advantageous system. In the case of the adpption of the multiple form of government the explanation we have seen to lie in the historical circumstances under which these governments came into existence. In the present case the explanation lies in the prevalence of the belief that a constitutional separation of powers is necessary in order to maintain the political liberties of the people. This belief in turn rests upon the belief that any authority possessing political power will seek to increase its power and that, unless it is subject to control by other authorities, there is the grave danger that it will sooner or later exercise these powers in such a way as to destroy political liberty and put in jeopardy, if not absolutely to annul, the most cherished of individual rights.

For the acceptance of this theory the great French writer Montesquieu is chiefly responsible. In his notable work, “The Spirit of the Laws," published in I748, Montesquieu sought among other things to discover the secret of the enjoyment by the people of England of political liberty while those of most European countries were practically without political rights. By a mistaken interpretation of the British constitutional system he thought that the answer to this secret was to be found in the fact that in that country the 
powers of government, instead of resting wholly in the hands of a single organ, were distributed among the three great branches of government. In point of fact the real explanation of the individual and political rights enjoyed by the inhabitants of Great Britain was to be found in the development of that great body of legal rules known as the common law of England, a body of laws which Englishmen rightly looked upon as their most cherished possession and which they were prepared to defend to the utmost. The fundamental principles at the basis of this jurisprudence, as it affected the question of government, were that all government should be one of law and that this law should have as its prime purpose the protection and promotion of the rights of the people. The only real protection that the people of England have had against tyranny, or indeed have at the present time, is their determination that these principles shall prevail.

This theory of Montesquieu met with almost unanimous acceptance in America. It was due to a belief in its validity, and to a failure similar to that of Montesquieu to understand the real nature of the political system of Great Britain, that the principle of the separation of powers was made one of the fundamental features of our governmental system.

It may well be that at the time our constitution was framed the danger of an illegitimate use of power and the possible establishment of a tyranny was sufficiently real to warrant the taking of unusual precautions to meet it. Granting this, the question nevertheless remains whether any such need now exists; whether, in view of the manifestly greater technical advantages of the system of a union of powers, steady progress towards that system should not be attempted. In two respects conditions are now radically different from what they were when our government was 
first established.' Public opinion is now of so great power, and possessed of such effective means for its expression, that it is almost inconceivable that any government authority could seize power that was not its for the purpose of transforming the government in any way not acceptable to the people. The danger of the establishment of a tyranny so much feared by our forefathers is almost non-existent. In the second place the demands upon the government for positive action are enormously greater than they were, and are growing all the time. Restraints upon the action of government which were felt to a relatively slight degree are now becoming intolerable. It is of first importance, therefore, that we should at least realize to what features of our constitutional systems these restraints are due.

If we turn now from a comparison of the relative advantages of a union or separation of powers, constitutionally speaking, to that of their union or separation as regards their actual exercise we will find all the advantages the other way. The system under which the whole responsibility for exercise of each power is vested in a separate organ possesses great advantages over that whereby cooperation on the part of two or more branches of the government is required before action can be had. It is desirable that the whole legislative power shall be vested in the legislative branch of the government, the executive in the executive, the administrative in the administrative and the judicial in the judicial. It is possible that an exception to this may be desirable in the case of the treaty making power and possibly one or two other matters. The principle of the definite location of the exercise of each power in a distinct organ is, however, the correct one. The reasons for this are obvious and have been fully set forth in our consideration of the systems of government of Great Britain and the 
United States. The evils resulting from the Congress intervening in executive and administrative matters are constantly in evidence. The manner in which public funds are voted for local improvements which correspond to no national need, the insistence upon the building of post-offices and other public buildings, the maintenance of navy yards, army posts and local offices which are not necessary; and in many cases positive drags upon the services to which they relate, are the most striking illustrations of the bad consequences of this system. The damage done by the attempt of Congress to control matters of administration affects, however, almost every branch and phase of administration.

In like manner the work of securing desirable legislation is much complicated by the intervention of the President. If Congress withdrew from the field of administration the main argument in favor of the President actively intervening in the legislative field would be destroyed. It is hardly a satisfactory condition of affairs when a single man can make his individual judgment prevail over that of the Congress, such as took place when an immigration bill was on three occasions defeated by the vetoes of three successive presidents.

It is of course recognized that the several branches of a government should at all times be regarded as but parts of a single organization and that means should exist by which their harmonious ${ }^{\circ}$ cooperation for the attainment of common ends may always be had. This is secured by the vesting of all authority in the first instance in a single one of the branches, the legislative. If combined with this there can be a personal union of power as exists in the British system so much the better. 


$$
1
$$




\section{PART VI}

THE ORGANIZATION OF THE SEVERAL BRANCHES OF GOVERNMENT 


\section{CHAPTER XII}

\section{THE ELECTORAL BRANCH}

In the preceding chapters we have sought to raise and discuss in their logical order those fundamental questions which have to be met by all peoples in organizing themselves as States and framing schemes of government through which the latter may act. These questions are all of what may be termed a constitutional character, since definite answers to them must be given at the time that systems of government are brought into existence. It is these questions, or rather the answers that are given to them, which determine the type of government resulting and thus serve to make known the really fundamental differences between the governments of modern States. Until they are settled it is impossible for a people even to consider, much less to answer, the many more subordinate questions that are involved in the organization of a government and the determination of its methods of procedure.

Having cleared the way by an examination of these basic matters, we now pass to a consideration of questions of quite a different class. They are designated different since, for the most part, they are not constitutional in the sense that answers to them must be given in framing a formal constitution, and because they deal with specific parts, or branches, of government rather than the government as a whole.

In considering these questions it will not be practicable for us to give them the same detailed examination that we 
have in the case of the first or constitutional class of questions. This arises from the fact that, in proportion as we push our inquiry from general to less general questions, the field for variations in practice widens. Anything like a detailed examination of every question arising in the work of actually framing the details of governmental organization and procedure would consequently require a work many times longer than the one here undertaken.' All that can be attempted, therefore, is an analysis of the several problems that are presented in providing for the organization of the five branches into which, as we have seen, the governmental structure may be divided; an indication of the more important considerations that must be taken into account in deciding between alternative lines of action that are open; and a summary statement of how these several problems have in fact been met by our own and other governments.

In entering upon a consideration of these separate branches of government an exceedingly important distinction must be made: that between the electoral, legislative, judicial, executive and administrative functions of government as functions and the organs and branches of government bearing these designations. This is necessary since, as we have pointed out in our consideration of the union or separation of powers, we find the branches of government bearing these designations, in fact performing, or participating in the performance of, the functions pertaining primarily to other branches. This is especially so in the case of our own government.

Another point of equal importance is that, though we may study the several branches of government separately, sight must never be lost of the fact that these several branches are but parts of one machine and must always be studied from this viewpoint. In no small degree the most difficult 
questions presented in the whole field of government and administration are those having to do with the distribution of powers between these branches and the adjustment of their relations with each other to the end that all may work harmoniously as one piece of integrated machinery.

The Electorate the Foundation of Popular Government.- In a Popular Government of the representative type the electoral branch may be viewed as the foundation upon which the whole structure of government is erected. It is thus logical that a consideration of the several branches of government should begin with it.

A political community is composed of separate individuals each with his individual will, and, in the case of almost all modern States, of a great many individuals with correspondingly large numbers of separate wills. It is thus necessary to provide some means by which these several wills may be expressed and common decisions arrived at. There is but one method by which this can be done in a populous community - that through the device known as voting. In political science a person viewed as a voter in respect to matters political is termed an Elector and the entire body of citizen voters an Electorate. Concretely, therefore, the primary problem presented to a community desiring to establish a Popular Government is to organize itself as an electorate, or to make a selection of those of its members whom it desires to act in this capacity.

Determination of the Composition of the Electorate.

Were a political community composed wholly of individuals equally capable of expressing an intelligent opinion regarding matters of general interest the problem of providing a voting system through which a general will might be evolved from a collection of individual wills would be comparatively simple. In all communities, however, a very 
considerable proportion of the persons composing them are of a character manifestly disqualifying them for the exercise of political authority. Reference is made to persons of immature age, to those of unsound mind, and, in certain cases, to members of uncivilized or but partly civilized tribes who are included in political groupings of persons possessing a higher degree of intellectual development.

In addition to this class, regarding whose non-participation in the exercise of political powers there can be no question, there are, however, many other classes regarding the propriety or advisability of whose active participation in the exercise of political authority grave differences of opinion may exist, and in fact always have existed, even in those communities which have most unreservedly accepted the doctrine of popular sovereignty. Thus after more than a century of the application of this principle, opinion in the United States, Great Britain, France and Switzerland, no less than in other countries not having adopted this principle of popular sovereignty, is still widely divided regarding the criteria that should be applied in determining those members of the community who should actually exercise the sovereign political powers that are a common possession. The more important factors around which this difference of opinion has centered, and still in large degree centers, are those of race or color, sex, age, ownership or occupancy of land, the possession of property, the possession of education, the payment of taxes, political and occupational status, citizenship, and legal misconduct such as is represented by conviction of a serious crime, or bankruptcy, etc.

It needs but an enumeration of these several points to show how serious and difficult is this primary question of determining in whose hands shall rest the actual exercise of sovereignty. In no small part the internal political history 
of States resting upon the doctrine of popular sovereignty has been dominated by struggles having to do with this issue. In England the great questions of internal politics in the nineteenth century were those relative to the broadening of the electoral franchise and improving the machinery through which it was to be exercised. The great reform act of 1832 and the franchise acts of 1867,1884 and 1885 , concerned themselves solely with this fundamental question of the constitution of an electorate and a determination of how it should discharge its duties.

In the United States, in early days, acute discussion arose over the question of property and educational qualifications for the franchise. The question of color or race as a determining factor in respect to the possession of the franchise was one of the great issues arising out of the existence of the slavery of the negro race in the United States; an issue which it was sought to settle by the adoption of the Fifteenth Amendment to the federal constitution which declared that "the right of citizens of the United States to vote shall not be denied or abridged by the United States or by any state on account of race, color or previous condition of servitude." That this action did not settle this issue is, however, evidenced by the efforts on the part of many of the Southern states to prevent any actual exercise of the franchise by their negro citizens, first by illegal means, and, in more recent times, by such nominally legal devices as the so-called "Grandfather" clauses in their franchise laws.

At the present time the extent to which the franchise shall be conferred upon women constitutes one of the leading political issues now before the people.

In our insular dependencies, the Philippines and Porto Rico, this has been one of the difficult questions that the 
American authorities have had to meet in organizing a government for those dependencies.

Determination of the Electorate a Matter of Expediency: The Electoral Franchise Not a Natural Right.It is manifestly impracticable for us here to enter upon any detailed consideration of the arguments for and against the giving of weight to any particular factor in determining the composition of the electorate. We will therefore have to confine ourselves to one or two general observations which are deemed to be of importance, in order that the true nature of the problem may be made clear.

The first of these is that this whole problem of the determination of the composition of the electorate should be viewed strictly as a question of practical expediency. This is of importance since, wherever the demand is made for the extension of the franchise to a new class, the claim is made that such extension represents but the recognition of a natural right. Certainly we see this claim being constantly put forward by those who are now advocating the cause of women's suffrage in the United States. We have already stated that in our opinion there is no such thing as natural law, and consequently no such thing as natural rights. Apart from this, it must bë apparent that the determination of the composition of the electorate is a matter to be adjusted in accordance with the particular conditions of each case. Thus it is evident that, whether or not the suffrage should be conferred upon women, should be largely influenced by the attitude taken by the women themselves towards this grant; the legal and social status of the women in the community concerned; and the extent and character of their education and general training. It may well be that in one case the grant would be desirable and in another represent a real danger to the proper working of the politi- 
cal system of the country. In like manner the extension of the franchise which might be both feasible and desirable in a settled community long accustomed to the exercise of powers of self government might be fraught with grave dangers in the case of a more unsettled community or one which had not been accustomed to governing itself or acquiescing in legal determinations.

The Electorate in a Popular Government the Actual Possessor of Legal Sovereignty.- When a community that has adopted the principle of popular sovereignty makes provision for an electorate, it not only takes the first step towards the establishment of a government, but effects a profound change in respect to the location of the real powers of sovereignty. Though as a matter of theory sovereign authority may be deemed to reside in the entire body of the people, the actual power to make use of this authority is exclusively vested in the hands of that select portion of the community that has been erected into an electorate. This fact, which is one of great significance, can best be brought out by making a distinction between what may be called political sovereignty and legal sovereignty. With an electorate established, while political sovereignty continues to reside in the whole body of the people, legal sovereignty; that is, the power to make an actual legal use of this authority, passes to the electorate. It might seem that, under these circumstances, no object is gained in continuing to hold that the whole people is the ultimate source of political authority. This, however, is not so. We have here to do with a doctrine or political belief. It is of the utmost importance to preserve in this manner the political principle that the government represents, and should act for, the entire community, and not in the interests of any particular class; that, from this point of view, the electorate, though 
the possessor of absolute political authority, is in the position of a trustee and is under the obligation to exercise its authority in such a way as to promote the general interests of the public as opposed to its particular interest. In no other way can this political principle or ideal be equally well preserved than by keeping constantly in mind this fact that no matter where legal sovereignty may reside final political sovereignty should be deemed to rest in the whole body of the people.

The Right of Revolution.- Nor is this matter one purely of academic or theoretical interest. In it is involved a question which at times becomes a matter of overwhelming importance; that, namely, of the right of a people to revolt against their political authorities. We have seen that, with the constitution of an electorate, the actual exercise of sovereign powers passes to that body, the mass of the people back of the electorate possessing merely what has been designated as political sovereignty. After this step has been taken no change in the form or character of the government can be made except by or through this body. It is as though the people had granted a full, perpetual, and irrevocable power to the electorate to exercise for it all of its sovereign powers.

The question is thus presented, and in fact has repeatedly arisen, as to what action the people are justified in taking in those cases where the electorate persists in exercising its sovereign powers in a way doing violence to the wishes of the people. From the strictly legal point of view the latter are powerless. They can of course urge in the strongest way possible upon the electorate the taking of the action desired. If the latter is obdurate, the people must either acquiesce or take the law into their own hands; that is, revolt. This situation has usually arisen where an electorate, 
established upon a comparatively narrow basis, persists in using its powers in its own interests rather than those of the general public; permits grave evils or inequalities to remain uncorrected; or refuses to comply with the demand on the part of the people that they be given a larger representation in the electorate.

\section{The English Reform Act of 1832 Forced by Threat of} Revolution. - These are the conditions that existed in England during the first third of the nineteenth century. Electoral conditions were almost inconceivably bad. The electorate at that time was composed of the comparatively few persons who were freeholders, that is, owners of land according to a particular kind of title in the counties or rural districts, and a few persons, usually the members of the selfperpetuating municipal corporations, in boroughs or cities. There was no approach to equity in the districting of the country for electoral purposes. Some districts included less than a dozen electors who were wholly under the control of a single large landowner or member of the nobility. There were boroughs so completely controlled by single individuals, or a small group of individuals, that their representation was treated as property and was openly offered for sale and bought in the open market. Against all efforts to improve this condition of affairs the existing electorate opposed a steady resistance. Despairing of effecting a change through legal means; that is, through the action of Parliament, which alone had legal authority to act, the people began to resort to violent demionstrations. Only after it became evident that these demonstrations would be pushed to actual revolution did Parliament give way and place upon the statute books the great reform act of 1832 , the first of a long series of acts by which the electorate has been steadily broadened and its machinery of operation so improved 
that at the present time the actual exercise of political powers has been placed as completely in the hands of the people as in almost any other country in the world. In the forcing of the passage of the Reform Act of 1832 , we have therefore an example of the possessors of political sovereignty, dissatisfied with the action of their representatives, the possessors of legal sovereignty, resorting to the only means remaining to it to make its will prevail, that of revolution.

In this connection it is of interest to note that the militant suffragists in England are appealing to this same right of revolution as the only means in their hands, after all attempts at moral suasion have failed, to enforce their demands upon a recalcitrant electorate.

The Right of Revolution as Illustrated in Dorr's Rebellion in Rhode Island in I84I.- Much the best illustration of the right of the possessor of political sovereignty to rise in revolt against the possessor of legal sovereignty is, however, furnished by an event which occurred in our own country. Though, from the time of the Declaration of Independence, the people of the United States have been firm adherents to the doctrine of Popular Government, they were, during the early years of our history as a nation, by no means persuaded that the electorate for the exercise of the power of sovereignty should have the broad basis that it now has. A study of the history of the manner in which the people of the United States have solved this problem of the constitution of an electorate shows that most of the states started with an electorate resting upon a comparatively narrow basis, one in which the right to vote was hedged in by a large number of requirirements, such as the ownership of property, ability to read and write, and, in some cases, even a profession of faith, or membership in a 
religious congregation, and have progressively broadened the franchise in response to public opinion until the present condition of manhood suffrage for the most part prevails.

In almost all cases the existing electorate has bowed to the demand for a broadening of the franchise when it became clearly apparent that such demands represented the genuine will of the people. A notable exception to this, however, occurred in Rhode Island in $184 \mathrm{I}$. Under the provisions of its early constitution, adopted at a time when it was believed that the right of suffrage should be rigidly restricted, the electorate was so restricted that the power of voting was vested in the hands of a comparatively small number of persons. These persons thus constituted, in effect, a political oligarchy. With the rise of democratic ideas, demands for the broadening of the franchise were put forth with ever increasing strength. These demands the existing electorate persisted in ignoring. Whether because they sincerely believed that an extension of the franchise was unwise, or because they were unwilling to give up the monopoly of political power that they possessed, they steadily refused to acquiesce in the changes demanded. As the possessor of legal sovereignty their position was legally unassailable.

To meet this situation the people in I84I met in mass meetings, effected an organization and took the necessary steps for the assembling of a convention, the members of which should be elected by manhood suffrage, for the framing of a new constitution. This election was duly held; the persons elected came together, organized as a constitutional convention, framed a constitution and ordered it submitted to the people for approval at a special election to be held for that purpose. This election was in turn held and the constitution so framed was adopted by a clear majority. 
The members of the constitutional convention thereupon reassembled, and adopted a resolution which declared that:

Whereas, by return of the votes upon the constitution, it satisfactorily appears that the citizens of this state, in their original sovereign capacity have ratified and adopted said constitution by a large majority; and the will of the people thus decisively known ought to be implicitly obeyed and faithfully executed; we do therefore resolve and declare that said constitution rightfully ought to be, and is, paramount law and constitution of the State of Rhode Island and Providence Plantations; and we further resolve and declare for ourselves and in behalf of the people whom we represent that we will establish said constitution and sustain and defend the same by all necessary means.

Under this constitution an election was held at which a man by the name of Dorr was elected as Governor and other offices were filled.

In the meantime the existing government, resting upon the old constitution and the narrow electorate, remained in existence and continued to discharge the functions of government. The result was that there were in existence in Rhode Island at the same time two governments, each claiming to be the legal government of the state.

Efforts were then made by the new government to assume control of the government departments, and the conduct of governmental affairs. The old government appealed to the President of the United States to assist it in resisting this effort, basing its appeal upon the provision of the federal constitution ${ }^{1}$ that "the United States shall guarantee to every state in this Union a republican form of government, and shall protect each of them against invasion; and, on application of the legislature or of the executive (where the legislature cannot be convened) against domestic violence."

1 Art. IV, Sec. 4. 
The President acceded to this request and took steps to give the aid requested. Whereupon the new government collapsed. Efforts were subsequently made through an appeal to the Supreme Court of the United States to have this action reversed, and the new government declared to be the legal government of the state. This the Supreme Court refused to do in a decision handed down in $1845 .{ }^{1}$ In this decision the Supreme Court refused to decide directly which of the two governments was entitled to be deemed the legal government. It dismissed the action upon the ground that the enforcement of the clause of the federal constitution guaranteeing a republican form of government to each of the states was a matter resting with the President, and that it was improper for the courts to intervene in respect to the exercise of his discretion in relation thereto. The electorate constituting the source of legal authority of the existing government had, however, learned its lesson. It accordingly yielded in large part to the demands of the people which had been so energetically pressed, and the incident was closed.

We have given in some detail the incidents connected with this remarkable occurrence, which is known in history as Dorr's Rebellion, since it illustrates in a remarkably concrete way the relation that exists between the politically sovereign people and the legally sovereign electorate, and the trouble that may arise where the two are not in accord. It is of interest to note that the convention which passed the new constitution, in declaring that document to be the fundamental political law of the land, based its declaration upon the statement that this document represented the act of the citizens of the state, acting in their original sovereign capacity. Daniel Webster, who represented the old

1 Luther v. Borden, 7 How. I. 
government, in the case carried to the Supreme Court, argued that American law knew no such thing as mass action, that no act was legal that was not performed in compliance with the existing law of the land, and that, therefore, the constitution framed in total disregard of such law, was a nullity.

In this particular case the issue was not carried to the limits of armed revolution. The occurrence nevertheless furnishes a perfect illustration that cases may easily arise where a sovereign people may be morally, if not legally, justified in resorting to revolutionary means as the only means in their power of overthrowing a tyranny, and in making their sovereign will prevail. It need hardly be said, however, that resort to revolution is only justified when the grievance is one of real and great importance, and when all means of proceeding in a strictly legal manner have been exhausted.

The Problem of Electoral Procedure.-With the composition of the electorate determined, there is then presented the problem of devising the means through which this body may act. This involves doing three things: one, the adoption of a system for the determination of those members of the community who have the qualifications required of electors; second, the provision of means through which the electors will act, that is, cast their votes at elections; and, third, the provision of means for the counting of the votes and the authoritative declaration of the results.

Two methods are open for determining the electoral qualifications of voters; that of having persons claiming to have such qualifications prove their claims at the time that they tender their votes; and that of having these claims presented and passed upon some time prior to when the voting takes place. The objection to the first method is that it is 
calculated to foment disorder at a time when the maintenance of order is at best a difficult matter, and that it greatly delays the work of voting. There are in fact many cases where a proper decision cannot be summarily made since the production of proof may be required to establish or reject the claim. Due to these objections most countries have adopted the second method. This means that there is established what is known as a registration system composed of boards or other bodies before whom persons claiming the right to vote appear some time before the election and establish their right to vote. On the basis of this, registration lists of qualified voters are made up for use at the time of the election. These lists serve the double purpose of making known who are entitled to vote, and of preventing duplicate voting by having each name checked as its owner casts his ballot.

Though this system would seem to be a simple one great difficulty is encountered in its practical operation. This arises, partly from the fact that the composition of the electorate of any district is constantly changing through persons attaining the age or other qualifications entitling them to become voters, death, and removal from one district to another; partly from the difficulty of securing registration boards that will act in a non-partisan and honest manner; and partly from the difficulty in detecting and preventing deliberate fraud. In the United States the fraudulent registration of voters has been widely practiced in the past. At the present time conditions are much improved over what they were, though much still remains to make them thoroughly satisfactory.

The second phase of electoral procedure, that of the actual casting of votes, offers still wider opportunities for variation in practice. In England until a comparatively 
recent day, and in our own country in colonial days, and in the early years of the Republic, voting took place by each voter appearing openly before the election board or other officer charged with the duty of conducting the election and disclosing his vote. This system had the serious objection that under it bribery, that is, the purchase of votes, undue influence and even intimidation were easy. A candidate or persons acting in his behalf, who had paid persons to vote a certain way, and employers or others having persons dependent upon them, could readily determine how the persons so bribed and subject to their control voted.

This condition led to the demand for the secret ballot. To secure such secrecy there was established the system of written or printed ballots, which were dropped in an urn or other receptacle. At first separate ballots were employed for the several candidates being voted for. It was found in practice, however, that under this system it was still possible to determine how electors voted and that fraud was possible through the casting of more than one ballot. These evils were overcome through the adoption of what is known as the Australian ballot-system from the country where it was first used. This system consists in the use of a single ballot, furnished by the government instead of by the individual candidates, as was the case under the old system, bearing the names of all candidates, the voter indicating his choice by checking the name voted for. To insure secrecy separate booths are provided at each election post into which the voters go to mark their ballots. When marked, they are folded so that the manner in which they are marked is concealed and are dropped in the voting box. This system has given thoroughly satisfactory results and is now the one almost universally in use in the United States. 
The work of counting the votes and declaring the results is the third phase of a system of electoral procedure. The counting is done in the first instance by the boards conducting the elections and the results are forwarded to some central authority for verification and declaration of the results. We have seen that in the case of elections for President and Vice-President of the United States the central authority or canvassing board, to use the technical term, is Congress.

In the United States, and to a considerable extent in other countries, the principle is firmly established that legislative bodies shall be the final judges as to the qualifications of their members. Notwithstanding the care taken to prevent fraud many cases occur where fraud is practiced, or claims that it is practiced, are set up. This leads to so-called contested elections. These contests are heard by Congress and our state legislatures sitting practically as courts. Testimony is taken, arguments of candidates or their attorneys are heard and decisions rendered. Unfortunately these bodies in rendering their decisions are too often guided by political considerations rather than the evidence produced. In England this situation has been met by providing that all election contests shall be heard and decided in the first instance by judicial officers and the case rarely if ever occurs where the decision so rendered is not accepted. There is a strong demand that the same system should be adopted in our own country. That it would be a great improvement over the existing system can hardly be doubted.

In the foregoing we have done little more than analyze the several operations involved in providing the means by which the electorate may perform its functions and the more important considerations to which they give rise. Though present conditions represent a great improvement over 
those formerly existing much yet remains to be done to secure a system under which an independent and honest expression of opinion may be had from voters. Bribery, intimidation, fraud, and improper expenditure of money to influence voters are still practiced. In the attempt to control these, Congress and many of our state legislatures have passed what are known as corrupt practices acts, the purpose of which is to define what practices shall be deemed to be proper and what illegal, to provide penalties for the infraction of the latter, and means for enforcing them. Especially have these acts sought to put a limit upon the amount of money that may be spent by, or on behalf of, candidates and to determine the purposes for which such money may or may not be spent. They have also very generally provided for the publication of accounts by candidates showing what money had been raised on their behalf, who contributed this money and for what purpose it was spent. In England similar acts have been passed which are equally far-reaching in character.

The problem of the functions of the electoral branch; that is, the part that it should play in determining what shall be the policies of the government, has already been considered in our discussion of the two types of Popular Government, Democracy and Representative Government, and will receive further consideration in our chapter dealing with the rôle of political parties in modern governments. 


\section{CHAPTER XIII}

\section{THE LEGISLATIVE BRANCH}

But a moment's reflection shows that, in considering the several branches of government proper, first attention should be given to the legislative branch. This for a number of reasons. In the first place, as will shortly appear in our analysis of the functions of this branch, the legislature is preeminently the organ made use of to complete the work of determining the character of government that shall be established and the manner in which governmental powers shall be exercised. The legislature takes up this work where the electorate, in the exercise of its constituent authority, leaves off. In a Unitary Government, it is the organ which determines how governmental powers shall be distributed territorially. In a Government of Union of Powers it is the organ which determines how governmental powers shall be distributed functionally. In some governments of a purely representative type, such as that of England, it exercises all the powers possessed by the electorate itself and, acting as the latter's agent, determines all the details of governmental organization and procedure. In practically all cases, it is deemed to be the organ of government which most directly and authoritatively represents and acts for the electorate. It, finally, is the organ most usually employed in determining when a new appeal shall be made to the electorate to exercise its constituent powers for the purpose of determining what modification, if any, 
shall be made in the fundamental features of the political system as in force.

In the second place, in most, if not all, Representative Governments, the legislature is the organ through which the electorate, after a governmental system has once been established, currently makes known its will in respect to the policies that should be followed by such government. In those governments in which the chief executive and the judges are not elected by the people, it is the only organ through which this public will is authoritatively expressed.

Finally, it is the organ which, in the practical operation of government, determines for the most part the action to be taken. In large part the other organs have but the function of putting into execution the policies thus determined upon. The only important exception to this is the determination of foreign policies and the conduct of relations with other governments which, for reasons which will hereafter appear, are usually in the hands of the chief executive.

Analysis of the Problem.- Following the principle of procedure employed throughout this work, our first effort will be directed to the attempt to analyze the problems presented in organizing, determining the procedure, and ac-. tually conducting the work falling upon a legislative body. Only as we start with a clear idea of the several elements or factors that are involved in a complicated problem can we hope to reach any thorough understanding of it or to consider with advantage the steps that must be taken if a satisfactory system is to be had. Employing this method, examination shows that the problem of organizing and operating the legislative branch of a government can be resolved into the following distinct elements :

I. Determination of its functions or duties. 
2. Determination of its structural character.

3. Determination of its composition and method of selecting its members.

4. Determination of its life or duration.

5. Determination of its powers and privileges.

6. Determination of its methods of procedure.

It is our purpose to consider briefly the nature of each of these specific tasks in turn.

Determination of the Functions or Duties of the Legislative Branch. - In respect to no branch of government is there a greater misconception regarding the real character of its duties than exists in the case of the legislative branch of a modern government. In the popular mind this branch has but one duty to perform, that of the enactment of laws. That this is one of its great duties no one will question. If, however, we examine closely the part played by a legislative assembly in the actual conduct of the affairs of government, it will be found that its activities extend far beyond this field. Analysis will show that a modern legislature, such as the Congress of the United States, performs at least seven functions that may be clearly distinguished; those, namely, of acting as :

I. A constituent assembly or constitutional convention.

2. A canvassing board and electoral college.-

3. An organ of public opinion.

4. A board of directors for the government corporation.

5. An organ of legislation.

6. An executive council -

7. A high court of justice.

Congress as a Constituent Assembly or Constitutional Convention. - In our consideration of the general problem of the adoption, revision and amendment of constitutions, we have seen that the electorate in a Representative Gov- 
ernment can proceed in three ways in making provision for the means by which its constitution may be modified. It can: (I) retain in its own hands the work of initiating and adopting constitutional changes; or (2) it can vest the taking of such action in the hands of the government; or (3) it can provide for the participation of both itself and its government in such work. Of these three methods the American people have chosen the second. The federal constitution thus provides two ways in which its provisions may be altered, both of which require that the work shall be undertaken at the instance of the government. The first is that Congress may at any time by a two-thirds vote of both of its houses, propose specific amendments. The second is that it shall provide for the assembling of a special convention to consider the general revision of the constitution whenever two-thirds of the states so request. In both cases the amendments so formulated must be adopted or ratified by the legislatures of at least three-fourths of the states before they become effective.

Manifestly we have here to do with a duty of Congress that should be clearly distinguished from that of legislation, strictly speaking. This duty is one which has been very much in evidence in recent years. Proceeding under the first method the constitution has during the past few years been amended in important respects. By an amendment adopted February 25, r9r3, power was conferred upon Congress to levy and collect taxes upon incomes without having to have such taxes apportioned among the several states. It is under this provision that Congress has been enabled to provide for the levying of the present system of income taxes the proceeds of which constitute at the present time such a large part of the national income. One of the prime motives for the passage of this amendment was 
to strengthen the financial powers of the national government in case of war. Its adoption must thus be classed among the important measures of military preparedness of our country. By an amendment adopted May 3I, I9I3, the method of electing Senators was changed from that of their selection by the states in such manner as they saw fit to that of direct election by the people. At the present time an amendment providing for the establishment of prohibition in respect to intoxicating liquors has been proposed by Congress and is pending ratification by the states, while another amendment providing for woman suffrage is now under consideration by Congress.

Congress as a Canvassing Board and Electoral College.- Another specific duty of Congress is that of acting as a board to canvass the vote cast in the electoral college for President and Vice President, and declare the results; and, in case of the failure of such body to make a choice, that one of its chambers, the House of Representatives, shall choose by ballot a President from among the three candidates having received the largest vote in the electoral college and the other chamber, the Senate, shall choose a Vice President from among the two candidates receiving the largest vote. In making the choice of President the vote is by states, each state casting a single vote.

Normally this function is of but a nominal character. On several occasions, however, it has been one of great importance. This was the case in I8Or and I825, when the electoral college failed to make a choice of President and Vice President and the election of these officers was thrown into the House of Representatives: and in 1876 , when it had to decide whether Mr. Hayes or Mr. Tilden had been duly elected. The latter issue was finally decided through referring the matter to a specially constituted electoral commis- 
sion composed of five Senators, five Representatives and five Justices of the Supreme Court of the United States.

Congress as an Organ of Public Opinion.- Popular Government has been defined as a government of public opinion. In such a government it is imperative therefore that means shall be provided by which such opinion may, not only be formulated, but authoritatively expressed. At the present time public opinion is formed and made manifest through a number of agencies. Of these mention may specially be made of the press and political parties. The function of the latter as the expounder of public opinion will be examined in our chapter on the rôle of political parties in modern governments. No one of these agencies, however, has the power authoritatively to declare the public will. This is the function of Congress, and it is one of its most important functions.

The importance of distinguishing between this function and that of legislation may be seen if we study the history of parliamentary institutions, or examine the real character of many legislative bodies as they exist at the present time. Thus if we examine the history of the rise and development of the British Parliament, the mother of all modern legislative bodies, it will be found that originally the primary, if not sole, function of that body was that of furnishing an organ through which public opinion, or at least the opinion of that part of the community to which a participation in the conduct of public affairs was accorded, might be secured. The British Parliament in its early days was in effect nothing more than the grand assize of the nation in which matters of public interest were discussed and expression given to opinions regarding policies that should be pursued. As President Wilson has pointed out in his exceptionally acute analysis of our constitutional system: 
Not until after the Revolution of I688 was Parliament looked upon as modern Englishmen look upon it, as chiefly interesting because of the laws it could make. . . . For at least four of the six hundreds years during which it has been an instrument of constitutional government, it was looked upon merely as the "grand assize," the great session, of the nation. . . . They (the Parliament) were meant to be talking shops. The name "Parliament" is no accidental indication of their function. . . . It was as far as possible from the original purpose of representative assemilies that they should conduct government. ${ }^{1}$

This distinction moreover is not merely one of historical interest. If we study the practical workings of the two greatest parliamentary bodies now in existence, the English Parliament and the Congress of the United States, it will be found that there is a strong and steady tendency towards the vesting of actual responsibility for the initiation and determination of the character of new legislation in the hands of the executive and of confining the participation of legislative bodies to that of passing upon proposals so brought before it. In England this movement has gone so far that it can almost be said that Parliament has ceased to be a legislative body, practically speaking, and has reverted to its original function of serving as an organ of public opinion. All legislation of importance is now drafted by the ministry in power and is put through that body without change except as the ministry may acquiesce in such modification. The inability of the House to modify ministerial proposals arises from the fact that the ministry in power necessarily has a majority in the House and this, majority, under the practice now firmly established, is practically pledged in advance to make its action conform in all respects to such ministry. The power of the individual member to introduce measures and secure their passage has

1 "Constitutional Government in the United States," 1908, pp. I0-II. 


\section{THE GOVERNMENT OF MODERN STATES}

steadily diminished until it no longer has any significance in determining the character of legislation that shall be enacted.

In the United States we are still in the midst of a similar evolution. More and more the people are looking to the President in the case of the national government and to the Governors, in the governments of the states, to formulate and secure the enactment of all acts of general importance. There can be no doubt moreover that this movement is one which has generally commended itself to the populations of both countries.

In Germany a similar condition exists, not merely as a matter of practice, but of law. It is hardly going too far to say that almost the sole function of the Imperial Reichstag is to act as an organ of public opinion. All measures of importance originate in the Upper House, the Bundesrath, which body acts upon direct orders emanating from the executive branch of the governments of the constituent states; and the lower house, the Reichstag, has the function merely of considering the measures thus coming to it from the upper house.

It is furthermore evident that the distinction we are here making has also great importance in formulating policies and programs for the government of dependent territory. There are many cases where it would be unwise at once to confer legislative powers upon a popularly elected assembly, but where the establishment of an assembly to act as an organ of public opinion would be both wise and the most effective means of training a population in the art of government and of preparing it for the time when full powers of self-government might be conferred upon it.

Finally, it is of the utmost importance that this distinction should be kept in mind by those countries which are 
now for the first time seeking to establish Popular Government.

The leading feature of such attempts in all cases is the creation of a National Assembly. In each case there is presented the fundamental question of determining the nature of the duties or powers that shall be conferred upon that body. It was the fortune of the author to have participated in attempts to work out this problem in a concrete case. From October I, I9I4, to June I, 19I6, he served as legal adviser to the Chinese Government, with the special duty of giving advice regarding the framing of a permanent constitution to take the place of the provisional constitution then in force. Of the various questions presented to him for consideration and advice none was more important than the one we are now considering. It arose in connection with both the establishment and definition of powers of a National Assembly for the country as a whole, and the establishment and definition of powers of popular assemblies for the individual provinces into which China is divided. This led the author to seek to determine why it was that in practically all cases the first attempts to create popular assemblies resulted in failures; that, with almost no exception, these bodies proved to be incompetent bodies and that their establishment was speedily followed by disorganization, disorder and ultimately their dissolution or a great curtailment of their powers.

The explanation of this the author believed to lie in the failure on the part of those responsible for the establishment of these bodies to make the distinction between the function of a National Assembly as an organ of public opinion and one of legislation. The mistake was made in attempting at once to bring into existence a National Assembly that should exercise full legislative powers. There 
was a complete failure to recognize; on the one hand, the impossibility that a body created under conditions such as obtained, composed of persons utterly untrained in the art of law-making, having no clearly defined legislative program that they were pledged to carry out, with no experience in the technique of government, and no organized public opinion to control them, could possibly perform effectively the work of law-making; and, on the pther, the great services that a National Assembly, though having no legislative powers, could render in the way of -serving as an organ through which public opinion in respect to governmental policies and action might be formulated and authoritatively expressed.

The situation there and elsewhere is clearly one where progress towards the establishment of a Popular Government can best be made step by step. The first step in the evolution from an Autocracy to Poputar Government is the establishment of the principle that the government shall be one of law instead of one of authority. This requires no change in the structure of government but merely one of procedure in the exercise of powers. It, however, lays the essential basis upon which all future action must rest. The next step is the creation of a National Assembly that will furnish the means through which the public may make known its wishes regarding governmental policies, and express itself regarding the manner in which governmental affairs are actually conducted. The establishment of such a body, even though it has but this single function, represents an enormous advance in the direction of giving to the public a voice in the administration of public affairs and an actual influence and control over such administration.

That this voice and influence may be effective it is necessary that provision be made by the law establishing the 
Assembly for two things: one, that the chief executive shall lay before it adequate information regarding the conduct of the financial and other operations of the government; and two, that no act of general legislation shall be enacted or put in force until the Assembly has been given an opportunity to consider and express its opinion regarding it. To meet these two needs the author recommended to the Chinese Government that, in drafting provisions for a National Assembly and Provincial Assemblies the following things be done: First, that the Assembly in each case be made an organ having but the single function of serving as an organ of public opinion as that function has been described in the forgoing pages; second, that legislative power be not conferred upon it but continue to reside in the hands of the chief executive; third, that this officer, in exercising this power, should do so in the following way: All proposed legislation of a general character should be embodied in the form of a draft or bill; this bill should then be submitted to the Assembly for its consideration and adequate time be given to it in which to consider such proposal and to draft a report expressing its conclusions; that the Assembly should proceed to the discussion of the proposal and its amendment in precisely the manner in which assemblies having legislative powers consider and amend bills coming before them for action; that the bill as amended, accompanied by a report explaining and justifying the changes suggested, if any, should then be returned to the chief executive; and that the latter should thereupon accept or reject such of the suggestions as he deemed wise, and promulgate the draft as law.

Secondly, it was recommended that power be conferred upon the Assembly on its own initiative to take up matters for consideration and, by means of memorials addressed to 
the chief executive, to recommend that certain action be taken by him, or that he formulate and lay before it proposals for legislation which in the opinion of the Assembly it was desirable to have enacted.

Finally, it was recommended that the definite obligation be imposed upon the chief executive, annually, or at more frequent intervals, to lay before the Assembly a report of the financial operations of the government and an administrative report giving an account of the manner in which the affairs of the government had been conducted during the period covered.

It will be seen that according to this proposal full authority and responsibility was imposed upon the chief executive for all acts both legislative and administrative. On the other hand it was provided that this authority should be exercised strictly in accordance with law and that a procedure should be followed that would insure a full opportunity to the people, acting through their popular assembly, to express their opinion in respect to both action proposed and had.

It might be held that in view of the fact that the powers of the Assembly are purely recommendatory, advisory, and critical, that that body would have no real determining voice in respect to the conduct of affairs and that the chief executive would be subject to no adequate control. This is true from the strictly legal and procedural standpoint. From the moral standpoint, however, conditions would be otherwise. If the Assembly performs its duties in a patriotic and proper manner; that is, with regard to the public interests, rather than the personal interests of its members, and of the localities which they represent, it is certain that great weight would be given to its recommendations and criticism. If its action is not of this character it is not 
desirable that its wishes should be followed. The chief executive would always be under a strong incentive to make his action conform to the will of the Assembly so far as he could do so without sacrificing the interests of the State, and to conduct the affairs of government in such a manner as not to expose his action to damaging criticism, since by so doing the difficulties of his task would be lessened, and his position fortified. The real danger would be that he would yield to popular pressure when he should not do so, rather than that he would stubbornly oppose the legitimate wishes of the people. In the final analysis it would be the will of the people, if such will were properly formulated, that would prevail.

This question of the function of the legislative branch of government as an organ of public opinion has been considered thus fully since it is a matter of such extreme importance in respect to those peoples in Russia, China, and elsewhere who are seeking for the first time to establish a really popular government.

Congress as a Board of Directors for the Government Corporation.- In the foregoing we have pointed out how the function of a legislature as an organ of public opinion may, and should, be clearly distinguished from its function as an organ of legislation. It now becomes necessary to make yet another distinction, that between the function of a legislature as a law-making body properly speaking and that of its function as a board of directors for the government corporation.

Examination of the work of any legislative body reveals the fact that the great bulk of its activities has to do with such matters as the determination, subject to constitutional limitations, of how the government, and particularly the administrative branch of the government, shall be or- 
ganized, what work shall be undertaken, how such work shall be performed, what sums of money shall be applied to such purposes and how this money shall be raised and disbursed. From this standpoint the legislature is the board of directors of the public corporation. Representing and acting for the citizen stockholders, it is its function to give orders to administrative officers; and, as a correlative and necessary function, to take such action as will enable it at all times to exercise a rigid supervision and control over the latter with a view to seeing that its orders are properly and efficiently carried out.

Manifestly this function is quite distinct from that of acting as a law-making body strictly speaking. It is unfortunate that the same designation, "laws " or "statutes," is given to both classes of documents through which the action had is set forth. Laws from the juristic standpoint have to do with the formulation and enactment of general rules of conduct to govern the relations between individuals and between individuals and the government. They have to do with rights and duties and the means of their enforcement. They are intended to be general and permanent. Enactments for the purpose of giving directions to officers of the government are for the most part but administrative orders. The major part of them have only a temporary end in view. Of this character are the annual or biennial appropriation acts, acts authorizing the construction of a bridge or public building, etc.

Here again it may seem that the distinction that it is sought to set up is not one merely of academic interest. In point of fact it is one of great practical importance. First and foremost there is immediately raised the question as to the extent to which it is desirable that a legislative body shall take to itself this function of a board of di- 
rectors. President Wilson, one of the most acute students of government that this country has ever produced, is clearly of the negative opinion. Writing directly to this point he says :

The most serious comment, therefore, upon the development of the House of Representatives is that, in making itself an active part of the government and falling into the silence of an effective, business-like board of directors, it has forfeited the much higher office of gathering the common council of the nation and wielding the tremendous, the governing and sovereign, power of criticism. ${ }^{1}$

There are few, if any, more radical points of difference between the governments of England and the United States in their practical workings than is represented by the different ways in which this question has been answered. The British Parliament exercises this function to the least possible extent. It may be said to participate only in the most indirect way in the actual administration of affairs. It is the Crown, acting through its ministers, which prepares the governmental work-program, determines what organization shall be set up for the performance of governmental activities, and determines what funds shall be raised and how they shall be appropriated. It is true that revenue and appropriation bills must be laid before Parliament, and receive its formal approval. This, however, is little more than a formal requirement since no material change is ever made in them that does not meet with the approval of the ministry of the day. It does not enter within the conception of Parliament that it should have the determination of such administrative details as the fixing of the internal organization of services, the number of employees to be engaged, the salaries that shall be paid to them, etc.

1 "Constitutional Government in the United States," pp. IIO-IIr. 
In the American scheme of government exactly the opposite of this policy prevails. There is no detail of administrative organization, procedure or activity which is too petty for Congress not to concern itself with. Collectively one of its chambers passes upon nominations to important offices, while the members of both houses, individually, use every possible influence in their power to determine who shall be appointed to offices of all grades of importance. It, and not the executive, is the branch of the government that determines in almost the last detail what services shall be maintained, how such services shall be organized and conduct their business, what number of employees shall be engaged, what salaries shall be paid and how all moneys voted shall be expended.

It is not practicable here to enter into any extended comparison of the relative merits of the two systems. The writer can only say that, in his opinion, the British system is the proper one. Certainly there can be no question but that the British system has given a far more efficient and economical administration of governmental affairs than has the American system. ${ }^{1}$

This distinction between the two functions of enacting laws, properly speaking, and administrative orders is also of direct practical importance when a legislature enters upon the problem of organizing itself and determining its rules of procedure. It goes without saying that a body should organize itself and adopt rules of procedure with reference to the duties to be performed by it. Mani-

1 For a detailed account of this aspect of the British government in its practical operation see "The System of Financial Administration of Great Britain" by W. F. Willoughby, W. W. Willoughby, and Prof. S. M. Lindsay. "Studies in Administration," Institute for Government Research, 1917. 
fest as is the distinction between the two functions, when once stated, and well known as it is to students of goverrment and jurisprudence, it has been almost wholly ignored by Congress in providing for its organization and procedure. It has treated the two classes of duties as identical and has made no attempt to differentiate between them in working out the means for their performance. With two different functions to perform, it has organized and adopted rules with only one of them in mind. It has, not only made no attempt to organize with a view specially to the discharge of its duties as a board of directors, but does not even appreciate that it has here a special problem to be met. We have thus here at the outset an explanation, and that a fundamental one, why Congress does its governing work so poorly. ${ }^{1}$

Congress as an Organ of Legislation.- Not until we have a clear appreciation of the functions of a legislative body as an organ of public opinion and as a board of directors, and especially the distinction between those acts of legislation which constitute laws proper and those which are merely administrative orders, is it possible to appreciate the real part played by a legislature as a creator of law in the strict sense of the word. Much as we have narrowed the field of law-making by making these distinctions, it is necessary to narrow it yet further. As is well known the great bulk of English and American law as it exists today has not been created by act of formal legislation but

1 The author has handled this particular phase of our government in his paper "The Correlation of the Organization of Congress with that of the Executive." Proceedings of the American Political Science Association 1913-1914, pp. I55-167. In this paper the author, not only pointed out the failure on the part of Congress to organize and adopt rules having special reference to the performance of its board of directors' duties, but indicated the way in which this problem, in his opinion, could best be met. 
has developed through the slow process of judicial adjudication of disputes. This method, moreover, is the one which today is the chief determiner of law; only in small part is our law at the present time in statutory form.

It, moreover, is a matter of more than historical interest that only slowly did Parliament, or indeed legislative bodies generally, reach the position that the enactment of law was one of its functions. As Edward Jenks has brought out in his brilliant study, "Law and Politics in the Middle Ages," it was not for two hundred years after the establishment of Parliament in its modern form; that is the establishment of the Model Parliament of I295, that statutes were other than declarations of laws and customs claimed to be already in force. ${ }^{1}$

"If we glance," he writes, "at the rolls of the English Parliament we shall find that the great bulk of the petitions which are presented during the first two hundred years of its existence are complaints of the breach of the customs or requests for the confirmation of new customs which evil disposed persons will not observe.... What is this but to say that Parliament was a law-declaring rather than a law-making body? . . . To think of a legislator, or even a body of legislators as sitting down in the plenitude of absolutism to impose a law upon millions of human beings is to conceive an absurdity.... Law is made unconsciously by the men whom it most concerns; it is the deliberate result of human experience working from the known to the unknown, a little of knowledge won from ignorance, or order from chaos. . . The English Parliament was a splendid machine for the declaration of law.... The great problem which lay before the statesmen of the middle ages was to devise a machine which should declare and enforce law. The supreme triumph of English statesmanship is that it solved this problem some five hundred years before the rest of the Teutonic world."

1Jenks: "Law and Politics in the Middle Ages." 


\section{THE LEGISLATIVE BRANCH}

It, moreover, is a matter of importance to note that, only in comparatively recent times, did Parliament seek to do more than make known its wishes in respect to either legal or administrative matters, and that the expression of these wishes in the form of formal documents known as "statutes" was left to the executive. Parliament did nothing more than consider grievances and petitions for action to be taken by the Crown. These petitions were forwarded to the Crown and, when acceded to, the latter proceeded to put its decision into effect by drawing up and promulgating the formal document for making known its will. The statute itself was thus not drawn until after Parliament had been dissolved.

Against this practice Parliament protested, alleging that the statutes, when promulgated, in many cases failed adequately to carry into effect the action petitioned for by Parliament, and promised by the Crown. To meet this situation, Parliament began the practice of sending to the Crown a draft of the statute that it desired instead of a petition. This is the origin of the modern bill. This procedure was acquiesced in by the Crown in I4I4, and under Henry VII became the regular practice in at least all cases of importance. ${ }^{1}$

Even after Parliament had won its right to send up to the Crown its desires expressed in the form of a bill or statute, it was by no means established that the Parliament was the exclusive organ of legislation. The King continued to exercise an ordinance making power that was litthe to be distinguished from legislative powers. All during the Middle Ages and down to the Restoration, it may almost be said that England had two legislative organs the King in Parliament and the King in Council. This,

1 Maitland: "Constitutional History of England," p. 189. 
however, did not go without protest on the part of Parliament.

"In I610," writes Maitland, "the Commons protested it is the indubitable right of the people of this kingdom not to be made subject to any punishment that shall extend to their lives, land, bodies or goods other than such as are ordained by their common consent in Parliament." 1

Coke, then Chief Justice of the Court of Common Pleas, was consulted on this point, and, after consultation with three other judges upheld the contention of the Commons. James I, however, continued to exercise legislative powers through the issue of proclamations, and the question as to where legislative power was vested may be deemed to be one of the main issues between the Parliamentarians and the Stuarts. Not until the Revolution of I688 may Parliament be said to have definitely established itself as the organ of legislation of the government. Thereafter such powers as the Crown exercised in this field were those of an agent exercising delegated authority.

Coming down to the present time it may be said that there is a strong tendency for this function of a National Assembly to become one of increasing importance. This is due to two things: one the constantly increasing complexity of social relations and the corresponding complexity of the laws governing them; and, two, the radical changes in economic and social conditions which have rendered much of the old law inapplicable or difficult of application. To meet these two conditions legislative assemblies throughout the world have applied themselves to the task of codifying existing law and of reforming it so as better to meet modern conditions. This has thrown a large burden of pure law

1 Op. cit., p. 25\%. 
making upon such bodies. This burden it has met chiefly through the device of having the work of codification or law drafting performed in the first instance by special commissions or other outside agencies and has confined its own action to the revision and enactments of proposals so prepared.

Congress as an Executive Council.- In practically all governments, though the executive power is definitely vested in the hands of the chief magistrate, recognition is had of the need for some body that may act in an advisory capacity to that officer in the exercise of this power. In England this body consisted of the Privy Council, from which was evolved by a process of evolution the present British Cabinet. In France there is the Council of State. In our own government it was the intention of the framers of our constitution that the Senate should act in this capacity. Thus the constitution, in conferring power upon the President to make treaties and appointments to important offices, provides that he shall exercise these powers "by and with the advice and consent of the Senate." The use of this expression, instead of one indicating merely that his action must meet with the approval of the Senate, shows clearly that the intention was that the President should actually confer with, and get the advice of, the Senate in performing these acts.

Here again is furnished an illustration of how an express constitutional provision may, in practice, be made to work quite differently from that planned. At the outset, Washington, the first President, made one or two attempts to carry out the spirit of this provision by meeting the Senate in person for the purpose of conferring with it in respect to certain matters. The results of such attempts were not such as to encourage him to continue them. He accordingly inaugurated the plan of first formulating his proposed action 
in definite form and transmitting it to the Senate for its approval, a procedure which has uniformly been followed since then. It has resulted from this that the Senate has in fact acted rather as an approving body than a consultative and advisory council.

The reason why the Senate failed to function as an executive council in the manner intended is not difficult to see. To work effectively, an advisory body should be composed of persons selected by the officer to whom its advice is to be given. It was accordingly but natural that the President should look for advice rather to his cabinet composed of his own appointees than to the Senate, in the selection of whose members he had no voice. The framers of the constitution, moreover, failed to take into consideration the extent to which party interests would control governmental action. The fact that the Senate would include a number of members, and at times a majority of members, of the party opposed to the President, was in itself sufficient to make it unsuitable as an advisory body strictly speaking.

Though the Senate thus does not act as an executive council in the manner intended, the participation thus granted to it in the exercise of the executive power has, nevertheless, proven to be a matter of great consequence in the actual operation of government. It has resulted in a more or less permanent contest between the President and the Senate in respect to the exercise of the treaty making and appointing powers. In respect to the first the Senate has not contented itself with the mere giving of counsel or the approval or disapproval of treaties laid before it by the President. It has not hesitated to amend such treaties, and, in other ways; has sought to make of itself a coordinate, if not the dominant, body for the performance of this duty. In respect to the latter it has pushed its powers so far that it has to a great 
extent taken to itself the duty of selecting in the first instance who shall be appointed to a large class of important positions. It has been able to do so by the establishment of a principle or practice known as " courtesy of the Senate," under which nominations to positions in the field services of the government made by the President will be rejected by the Senate if such nominations are objected to by the Senators of the states in which such positions are located. A contributing factor has also been the extent to which appointments to office have been looked upon as political patronage. The practice thus is an integral part of the "spoils system" which has established itself so strongly upon the country. A remedy for this condition has been sought in the restriction of the requirement that Presidential appointments shall require the approval of the Senate to the narrowest possible limits. Such action was strongly recommended by President Taft in transmitting to Congress a report of his Commission on Economy and Efficiency dealing with methods of appointment. ${ }^{1}$

Before leaving this subject mention should be made of a practice that does obtain, in which the idea of the Senate serving as a real executive council finds at least partial expression. Reference is made to the practice of the President conferring with the Committee on Foreign Affairs of the Senate in reference to the negotiation of treaties, or in taking any important action relative to foreign affairs. Much is to be said in favor of this practice. It meets the objection that is urged against such important matters resting wholly in the hands of a single officer, gives to the

1 "Economy and Efficiency in the Government Service." Message of the President of the United States. Transmitting Reports of the Commission on Economy and Efficiency, April 4, 19i2. House Doc. 670, 62nd Cong., and Sess. 
President counsel and advice which is often valuable, and tends greatly to securing harmony between the President and the Senate in the joint handling of these matters.

Congress as a High Court of Justice.-An essential feature of Representative Government is the provision of means by which representatives of the people may be held to an accounting for the manner in which they discharge their duties. TThis accountability may be secured in two ways: by the refusal of the electorate to return to office representatives with whose conduct it is dissatisfied; and by proceeding against them while still in office. For all ordinary cases of inefficiency or misconduct not of a grave character, the former method is sufficient. When officials are guilty of serious crime or of actions endangering the welfare of the State, or tending to bring the government into disrepute, a prompter and more drastic procedure is required. To meet these latter cases England early developed the system of what is known as impeachment of high officers. This system consists in bringing officers charged with such high crimes and misdemeanors before the House of Lords for trial and the infliction of such punishment, if guilt was established, as that body saw fit. When the House of Lords sat in that capacity it was said to sit as a High Court of Justice.

This system was borrowed by the framers of our constitution. They provided in that document that "the President, Vice President and all civil officers of the United States shall be removed from office on impeachment for, and conviction of, treason, bribery, or other high crimes and misdemeanors." In operating this system a distinction is made between the act of impeaching, that is, of accusing, officers and that of their trial. To the House of Representatives was entrusted the duty of examining all charges against 
the officers named and of determining whether justification existed for their impeachment. To the Senate was given the duty of trying all officers so impeached. In respect to the penalty that may be imposed, the constitution provides that " judgment in cases of impeachment shall not extend further than to removal from office, and disqualification to hold and enjoy any office of honor, trust or profit under the United States; but the party convicted shall nevertheless be liable and subject to indictment, trial, judgment, and punishment according to law."

This proceeding is one which has been employed in the case of one President, Andrew Johnson, and in the case of a certain number of justices of federal courts.

It should be noted that, for this purpose at least, members of Congress are not deemed to be civil officers. These officers, when guilty of misconduct, are proceeded against by their respective houses in accordance with the provision of the constitution that "each House may ... punish its members for disorderly behavior, and, with the concurrence of two-thirds, expel a member."

Determination of the Structural Character of the Legislative Branch: Unicameral or Bicameral Legislature.-Having reached a decision regarding the functions of the legislative branch, there is next presented the problem of determining the character of organization that it shall have in order that it may perform these functions. In practice this problem resolves itself, in the first instance, into the question as to whether the legislative branch shall be made to consist of one or two houses, or, to use the technical expression, be a unicameral or bicameral legislature. If, as is usually the case, the second alternative has been chosen. there is then presented the further question as to whether the two houses shall, or shall not, be coordinate in power; 
and, if not, what shall be their respective powers, and their relations to each other and to the other branches of government. As has been indicated, most States in organizing their governments have made provision for a bicameral legislature. Few more interesting questions in political science are presented than that of determining why this choice has been made and the consequences that have resulted from it. The explanation of why this decision has been made is found in two things: ( $\mathrm{I}$ ) the historical circumstances under which legislative bodies have come into existence; and (2) the supposed technical advantages of the bicameral over the unicameral system. Each of these reasons requires separate consideration.

Historical Development of the Bicameral System.The English Parliament is, in a very true sense, the mother of parliaments. It constitutes the first successful example of a legislature in the modern sense. It is but natural, therefore, that almost all nations in seeking to establish a legislature should look to it as a model. It has consequently influenced powerfully the character of all legislative bodies subsequently created. In regard to no feature has this been more true than in respect to its bicameral character. It is safe to say that had it not assumed this form there is little likelihood that this character of organization would now be so prevalent. It is thus of prime importance to determine how the decision to establish a bicameral legislature should have been made by the English people.

In seeking to do this the first point that stands out is that the English Parliament, like almost all English political institutions, was not a deliberate creation. It came into existence by a process of evolutionary change. No such thing as a deliberate weighing of the relative advantages of different types of organization took place. That the English Parlia- 
ment finally took the form of a bicameral body was due in large part to historical accident. At the time that it began to assume the definite form that it was thereafter to maintain, English society, or at least that part participating in any way in public affairs, was divided into three well defined classes: the Lords Spiritual, the Lords Temporal, and the Gentry or Commoners. When the King found it desirable to summon his Grand Council in order to secure aid, or funds, or for other purposes, each of these three classes, or their representatives, constituted distinct groups in it. Each, it was held, ought to speak and act for itself, determine what taxes or levies it would furnish, etc. For a long time it hung in the balance whether these three groups would meet together or separately. Finally, the Lords Temporal and Spiritual decided to throw in their lots with each other. The Commons, however, elected to sit apart. The result was the establishment of a general assembly or Parliament of two houses. This evolution was completed about the end of the thirteenth century, when the so-called Model Parliament of I 295 was summoned. The continued recognition of the distinction between the nobility and common people caused this form of organization to be maintained until the present day.

The next country to develop strong legislative bodies as a distinct branch of government was America. Here the bicameral system was generally adopted, partly since it was but natural that the American colonists should copy the institutions of the mother country, and partly because there was a special reason in their case why they should do so. This reason consisted in the fact that there were two interests to be represented: the mother country and the colonies themselves. Colonial legislatures were thus very generally made to consist of two houses, an upper house or Governors 


\section{6

Council, composed of members appointed by the Crown, or the Governor as representative of the Crown, and a lower house composed of members elected by the people. ${ }^{1}$

After the Declaration of Independence, the states retained, as far as conditions would permit, the form of government which they already had. In some cases new constitutions were not adopted until many years after they had established their independence of England. Even when they entered upon the work of framing new constitutions they adhered in great part to the form of government and the political institutions to which they were accustomed. Among these institutions so retained has been the bicameral legislature. New states, as they were erected out of our public domain, copied the main features of the political system of existing states. Without exception, therefore, the constituent states of the Union have a bicameral legislature.

When our federal constitution was framed, so firmly was established the principle of a two-chambered legislature, that there was little or no thought of doing otherwise than provide for such a body for the new government that was being established. Furthermore, the adoption of this type of legislature made it possible to meet two of the most difficult problems that confronted the framers of our constitution. These consisted in framing a system under which the identity or individuality of the separate states would not be merged to too great an extent in a single government, and the influence of the smaller states would not be overwhelmed by that of the larger. These two considerations were met by providing that the national legislature, Congress, should consist of two houses, a lower house, or House of Representatives, composed of members elected directly by the people, and an

${ }^{1}$ In Massachusetts, Connecticut and Rhode Island, the members of the Upper ${ }_{s}$ House were elected by the General Assemblies. 
upper house, or Senate, composed of members selected by the states, it being provided that each state, regardless of its size, should be entitled to two representatives, or Senators, as they are called. As originally adopted the constitution provided that the Senators should be chosen by the legislatures of the respective states for terms of six years. This system developed certain evils, the more important of which was the large use of money by candidates and the failure of legislatures to agree upon a choice, which led to the adoption in I9I 3 of an amendment providing that thereafter Senators should be elected directly by the people.

If we examine the circumstances under which modern European States have adopted a bicameral legislative system, it will be found that in some cases, as in that of Germany, this decision was made in order to meet special conditions, while in others, the only reason apparently was that they were influenced by the fact that this system was so generally employed.

Comparison of the Unicameral and Bicameral Systems.-The foregoing sketch of the circumstances under which the bicameral legislative system has come into general use is important as showing that this system has been adopted, not in pursuance of a reasoned belief in its superiority over the unicameral system, but as the result of historical accident, the necessity for meeting certain special problems, or a mere copying of existing institutions. Though this is so there is nevertheless a strong belief that this system has intrinsic merits which, apart from all other considerations, justify its employment. It is a matter of importance to determine whether this is so; for, if such technical advantages cannot be established, there is no warrant for the employment of this system except in those cases where very special reasons for so doing obtain. 
If the two systems be studied purely as pieces of governmental machinery it would seem that the unicameral system would be the one logically to be adopted. It is simple. Responsibility is definitely located. It furnishes the means for a direct authoritative representation of the electorate. It is the system invariably employed in providing for the exercise of general direction and rule-making powers in all large private corporations. The bicameral system, in contrast with this, is complicated and expensive. Responsibility is divided. It leads to delay in action. Two separate bodies have to be brought into accord before any action can be taken. In many cases this means that proposed action will be defeated; while, in almost all cases, the result is a compromise. What then are the supposed advantages of the system which are believed to be of sufficient advantage to more than counterbalance these undoubted disadvantages? Generally speaking, they are as follows: The bicameral system compels delay and deliberation; it makes it impossible for a legislature to be swept from its feet bya sudden wave of unreasoning popular opinion; it ensures that opportunity will always be given for a sober second thought; it ensures that measures before their adoption will undergo a careful revision; it makes possible a better representation of different interests in the government. It will thus be seen that, in a Popular Government, at Teâst, the special functions of a second chamber are those of serving as an organ of revision, a check upon democracy, an instrument by which conservatism in action may be had, and a means for securing a representation of interests that is not feasible in a single chamber composed of members elected directly by the people.

All of these are desirable ends. It must be evident, however, that if a second chamber is really to perform these functions it must be specially constituted with those ends in 
view. Its members in the first place should be selected in some other manner than that obtaining for the selection of the members of the lower house. The special effort should be made that it should have a less political character than the lower house; that is, should be composed of persons who will make their decisions rest upon considerations of the general welfare rather than political exigencies. The question is further presented, whether, in view of the fact that the main justification for a second chamber consists in securing deliberation and a reconsideration and revision of measures, that its powers should not be restricted to the performance of such functions; whether, in other words, the initiation of all measures should not take place in the lower house and the authority of the upper house be limited to considering these measures and returning them to the lower house with its recommendations, the final decision resting with the latter body.

In point of fact if we study the bicameral system from the standpoint of its actual character and operation, rather than from its theoretical or possible advantages, it will be found that the considerations which have been enumerated are met to but a comparatively slight extent. Especially is this true in the United States. In both our national and state governments the two houses are for all practical purposes coordinate in power in respect to matters of legislation; both are composed of members elected directly by the people; in both political considerations have equal weight; one is no more of a revising body than the other. It results in consequence that, in the United States, we have all the disadvantages of a two-chambered system with but few of its advantages.

In England the technical requirements of a bicameral system are met to a far greater extent. The upper house is 
composed of members holding their office for life. Most of them represent a distinct class while the others are selected as the result of offices held by them or the possession of special qualifications. In no case are they the direct representatives of particular political parties. They are thus free from the obligations resting upon members so selected. In practice all important measures originate in the lower and popular branch. Since the passage of the famous Parliament Act of I9I I the upper house no longer has the power of definitely rejecting measures coming to it from the lower house. The House of Lords, in a word, has precisely the character of a body whose sole function is that of delay, of forcing deliberation and reconsideration of measures, of subjecting such measures to technical revision, and generally of ensuring conservatism in the conduct of public affairs. In Canada the upper house of the Dominion Parliament is likewise composed of members holding office for life. Here, too, the dominant branch is the lower house, the upper house acting merely as a brake upon the lower, able at times to retard but not to prevent final action. It is not contended that the system either in England or Canada works with perfect satisfaction. In neither case does the upper house take its function as a revising body with sufficient seriousness. In both countries irritation is felt whenever the upper house holds up measures desired by the lower house. Indeed the feeling is more or less strong in both countries that these houses serve no useful purpose, or at least none of sufficient importance to warrant their maintenance. This condition of affairs only serves to raise more strongly the question whether, even under the best conditions, the bicameral system is one that meets modern conditions as well as the unicameral system.

It is little short of remarkable that, in view of the im- 
portance of the issue, so little attention has been given to this question. It is one which we regret that we cannot more fully consider here. Before leaving it, however, one or two general observations should be made. The first of these is that there is far greater justification for the adoption of a bicameral system in the case of a Multiple or Federal Government than in that of a Unitary Government. Through it, representation can be given to constituent states, as well as to the people as a whole, and a balance between large and small states better be maintained. A like justification exists in respect to the governments established for dependent territory, where it is desirable to have the two distinct interests of the mother country and the population of the dependency represented. The second is that no such justification exists in the case of our individual states. In the author's opinion, at least, a careful weighing of the advantages and disadvantages of the two systems, whether from the standpoint of theory or practice, would in the case of our individual states cause the decision to be made in favor of the unicameral system. To a still greater extent is this true of the governments established for municipalities and other minor political subdivisions.

Determination of the Composition and Method of Selection of Members of the Legislative Branch.- The determination of the composition or membership of legislative bodies and the manner in which such members shall be selected, gives rise to a number of important questions. Among these may be mentioned: the question of size, the length of term of members, the qualifications required of members, the method of their selection, provision for the representation of minorities, or proportional representation, and the requirement of a plurality or majority in order to elect. 
The Question of Size.-From the standpoint of efficiency in operation it is desirable that legislative bodies should be of comparatively small size. From the standpoint of representation, however, a larger membership is required. In practice the attempt has to be made to harmonize these two conflicting considerations. In general it may be said that legislative bodies have been given too large a membership. This is especially true in respect to the House of Representatives of the United States Government. This question of size comes up on the occasion of each decennial enumeration of the population, since the constitution provides that the number of representatives shall be apportioned among the states in proportion to their respective populations. Always the attempt has been made to avoid increasing the total number of members. Invariably, however, this attempt has failed, due to the unwillingness of the states whose populations have increased at a slower rate than those of others to have their representation reduced in order to offset the additional members that must be given to such other states. The result, therefore, has been the working out of a system under which no state will have its representation diminished, a system which has carried with it a constantly increasing total membership of the House.

The Length of Term of Members. - A second question is that of the length of terms of members, or, to state it in another way, the frequency with which elections will be held when the members are selected in this way. Here, too, there is a conflict of considerations. On the one hand it is desirable to have terms short in order that the electorate may effectively control their representatives. Short terms, however, have the very serious disadvantages that they put the government and the people to the expense and disturbing 
influences of frequent elections; they make a great demand on the time and energies of representatives, and interfere seriously with the discharge of their legislative duties; and they lessen the independence of representatives since they have constantly to keep in mind the effect of their votes on their chances of reelection. Men who would make the most desirable representatives are deterred from undertaking the task since they are unwilling to subject themselves to the expense and trouble entailed by frequent election contests. More than all, however, frequent elections lead to a constant shifting in the membership of legislatures, with the result that such bodies, where frequency in elections obtains, are composed in large part of new and inexperienced members. Regarding the result of this system in the United States, Mr. Jones, in his work on "Statute Law Making," says:

The result of short terms is that, in the average American commonwealth, energy that should be devoted to legislation is devoted to party ballots. ... The biennial recurrence of the elections exhausts the energy and enthusiasm of the member. His salary hardly meets his expenses; it certainly is insufficient to support his family. After a first term he concludes to let someone else try it; he gives way to a "green" man who must spend his time in "learning the ropes." This succession of new recruits, under our present system, is one of the main causes of the mass of poorly drawn laws for which the legislature is blamed. . . . The difficulty under which we work on this account appears in the statistics of length of service as shown in biographical sketches in some of the legislative manuals. In the Minnesota House of Representatives in the session of I9II there were I20 members, 75 of whom had never served in the legislature before, 45 had served before, 20 for 2 terms, and 7 for 3 terms. In the House of Representatives of Missouri, in the session of I9II, there were 102 new members, and $4 \mathrm{I}$ who had seen service before, and of these 2 for 2 terms and 7 for 3 terms. Of the 95 members of the North Dakota House, in 1909, 7I were new men and 24 had served before, and of these 6 for 2 terms. In the 
Vermont House of Representatives of 246 members in I9I0-II, 22, less than ro\%, had served before and of these 9 for 2,5 for 3,3 for 5 , and 2 for 6 terms. $^{1}$

When one considers the character of the issues that arise in state legislatures there would seem to be no reason why so frequent appeals should be made to electorates. In the case of a central government the argument in favor of short terms is much stronger. Here new issues of great importance are constantly arising, and means should be provided by which electorates can express themselves promptly upon them.

The Qualifications of Members. - The qualifications that shall be required of members of the legislature constitutes another question that in the past has been of much greater importance than at the present time. In former times, the possession of property, adherence to a particular religious belief, were among the requirements most strenuously insisted upon. At the present time the tendency is to require of legislators no qualifications that are not demanded of electors or voters.

\section{The Method of Selection of Members: The General} Ticket and District Plans.- Much the most important question of all, however, is that of the method that will be employed in selecting members of the legislature. This is a question that is different for each house. We have already given some consideration to the question of the composition and method of selection of members of the upper house. In the case of most governments the policy has been pursued of giving greater stability to this house by providing that its members shall hold office in virtue of their status as members of the nobility, by appointment by the chief executive for life or long terms, by selection by some other branch of

${ }^{1}$ C. L. Jones: "Statue Law Making," pp. 12-I3. 
the government, or a specially constituted electoral college, or in some other manner than by direct election by the people. In marked contrast with this is the practice in both our national and state governments to have members of the upper house elected directly by the people, the main difference in procedure from that followed in the case of the lower house being that the membership is almost always, if not always, smaller, and the terms of office longer.

Turning now to the matter of the election of members of the lower house, it will be found that a large number of interesting and important variations in methods of procedure may be employed. Among the questions raised is that as to whether the principle of representation shall be that of the state as a whole, or of districts. Under the former system the voters participate in the election of all the representatives. Under the latter, the territory of the State is divided into as many districts as there are representatives to be elected and the voters participate only in the election of the single representative for the district in which they live. In case the latter method is employed the further question is raised as to whether residence within the district where they are candidates shall constitute one of the qualifications required of candidates. The relative merits of these different systems have been much discussed, and practice varies widely in different countries. In the United States the system of individual districts and the requirement in fact, if not in law, that candidates shall reside within the districts they are to represent, generally obtains. In England the system of individual districts exists, but members may be, and are, elected regardless of their residence. In France repeated trial has been made of both systems, which are there known as the system of scrutin de liste and scrutin d' arrondissement. 
The advantages claimed for the district system are that it establishes a more intimate relationship between representatives and their constituencies; that all parts of the state will be represented; and that, under it, an opportunity is afforded minority parties to secure representation. Under the general ticket plan it is evident that a party casting a majority of the votes can elect all the representatives, with the result that minority parties, even though they may constitute a very considerable part of the electorate, may be absolutely without representation. Under the district plan these minority parties, unless they are in a minority in all the districts taken individually, will secure a measure of representation. It should be noted, however, that under the district plan, it is quite possible for a party which is in a minority in the State as a whole to secure a majority of the representatives. This results when the bulk of the voting strength of the majority party is concentrated in a few districts while that of the minority party is more widely distributed.

The advantages claimed for the general ticket plan are: That it ensures that the majority party will prevail; that the greater freedom allowed in selecting candidates permits of the election of superior men; and that, inasmuch as the members elected represent the whole State, instead of single districts, they will make their action conform to the welfare of the State as a whole, rather than to interests of particular districts. By many, the district plan in vogue in the United States is held to be largely responsible for what is known as the "pork barrel " evil; that is, the practice of each member seeking to secure the expenditure of as large an amount as possible of public money in his district, regardless of whether there is more urgent need for such expenditure elsewhere. Without denying that there may be some basis 
for this contention, experience elsewhere would seem to indicate that this evil is one which can only be effectively controlled by the development of a strong public opinion that will discountenance it.

The Question of Minority or Proportional Representation. - In contrasting the relative advantages and disadvantages of the general ticket and district plans an important issue of principle, as well as of practice, is raised. This consists in the determination of the conditions that ought to prevail in respect to representation of majority and minority parties in legislative bodies. We have seen that neither the district nor the general ticket plan will always give satisfactory results. Under the former, a minority may and indeed often does, secure a majority of the representatives, a result which is manifestly illogical and contrary to the spirit of popular government. Under the latter the minority will fail to secure any representation at all though its strength may be but little inferior to that of the majority party. This result is believed to be undesirable from two standpoints: one, that it denies to a considerable portion of the people any participation in the conduct of their political affairs; and, two, that it relieves the party in power from the restraining influence of a strong opposition. Both of these are points of great importance. The first is so evident that no further comment is required. The second is one whose significance can be properly appreciated only by an examination of the actual workings of parliamentary institutions. All students of Popular Government place the highest importance upon the necessity for a strong opposition in all legislative bodies. It is its function to subject all proposals of the party in power to critical examination, and to compel such party at all times to justify its proposed action. It is the most effective means known for enforcing responsi- 
bility, exercising control, and raising issues to be passed upon by the electorate at ensuing elections. Without such opposition, the danger of abuse of power would be acute. It may thus be stated without hesitation that the system of selecting members of a legislative body should be such that assurance will be had that such an opposition will be present.

This problem of minority representation is complicated when the electorate, instead of being divided into two great parties, is divided into a number of parties, and especially so when no one party represents a majority of the voters. Logically it would seem that the ideal system would be one where each party would secure the number of representatives corresponding to its proportional strength. Under such a system the legislature would be a replica in miniature of the electorate. Many ingenious plans have been devised for accomplishing this purpose. These plans call for what is known as Proportional Representation. These systems, of which the most important is that brought forward for adoption in England in 1859 by Mr. Hare, provide for either what is known as cumulative or preferential voting. Under the former, voters are given more than one vote and are allowed to cast them all for a single candidate or distribute them among a number of candidates. Under the second, voters are permitted to indicate on their ballots, not only their first, but their second, or third, choice as well. It is not feasible for us to attempt here any detailed description of these systems or statement of the arguments that are brought forward in their support. It is merely desired to make known that here is an important problem that should receive consideration in an attempt to provide an electoral system. ${ }^{1}$

1 For information regarding this problem see: Humphrey's "Proportional Representation," Common's "Proportional Representation," and the publications of the Proportional Representation League. 
The attitude that one will take towards the adoption of any plan calculated to give proportional representation to all political parties will be influenced not a little by the extent to which he believes that it is desirable that minor as well as major political parties shall be fully represented in a legislative body. In the consideration that will hereafter be given of the function of political parties in modern governments, it will be pointed out that two systems of political parties are to be found in modern States; that known as the Two-Party System, which prevails in England and her Dominions, and in the United States, where voters are for the most part arrayed in two big parties, standing in opposition to each other; and that of the Multi-Party System, which prevails generally in other countries where voters are organized in a number of parties, no one of which represents a majority of the voters. Students of the political systems of England and the United States have laid great stress upon the necessity for the Two-Party System that there obtains, if Popular Government is to work successfully. It is held to be of prime importance that the control of the government at any one time shall be in the hands of a single strong party rather than in a combination of parties no one of which represents a majority of voters; that in this way only is relative permanency, unity and consistency of program to be secured and responsibility definitely located. The government resulting under the MultiParty System, it is claimed, results in constantly changing combinations of parties, compromises, and a consequent difficulty on the part of voters definitely to locate responsibility. This is a subject that will receive further consideration in another place. It is only mentioned here on account of its important bearing upon the subject under consideration.

The Requirement of a Majority or a Plurality in Order 
to Elect. - Still another point that must receive consideration in framing an electoral system is as to whether a majority or a plurality will be required in order to elect. When there are only two parties one of course will always receive a majority, except in rare cases where a tie results. When there are more than two parties, it will often happen that no candidate receives a majority, that is, more than half the votes cast. In such cases the decision must be made as to whether the candidate receiving the largest number of votes cast, though less than a majority, that is, receiving a plurality, will be deemed to be elected, or whether a new election shall take place. In England and the United States the plurality system under which the candidate receiving the largest number of votes is deemed elected, whether such number constitutes a majority or not, generally prevails. In France, Germany and on the Continent of Europe generally, the other system usually obtains. Under this system, if no candidate at the first election secures a majority, a second ballot is held to determine which of the two candidates receiving the largest number of votes at the first ballot shall be elected. This system has the great advantage that voters for the other candidates can indicate their preference as between the two leading candidates. It may well happen that such persons finding that they cannot elect their first choice will prefer to be represented by the candidate receiving the second largest number of votes, rather than by the one receiving the largest number of votes at the first ballot. It will, of course, not escape notice that the reason why England and the United States have adopted one system and the countries of Europe the other, lies primarily in the differences in their party systems. Where the two-party system obtains the issue between the majority and plurality systems is of relatively little importance. Where there are 
a number of parties, however, the matter is one of great importance.

The foregoing represents by no means all of the questions that have to be answered in determining the composition and method of selection of members of the legislative branch. They serve, however, to make known the general character of these questions and the important bearing that they have on the political system resulting.

Determination of the Life or Duration of Legislatures. - A feature that markedly distinguishes the legislative branch from the other branches of government, is that it does not have a continuous existence in the same way as do those other branches. By this is meant, not merely that there is a change in personnel but that the legislature as a legislature has an interrupted existence. In the first place all legislatures, without exception, are elected for fixed terms and when these terms expire they go out of existence and new legislatures are elected. Furthermore, many systems of government provide that legislatures may be brought to an end prior to the expiration of the term for which they are elected. Such for example is the system of England and Germany, where the lower house may be dissolved by the King or Emperor and new elections ordered, a proceeding which brings to an end the legislature then sitting.

When a legislature is terminated in either of these ways there is a complete end to its work, no matter in what stage it may be. The new legislature starts with an absolutely clean slate. It is not even organized; nor has it any rulcs of procedure. Its first task, therefore, is that of effecting an organization and of adopting rules to govern its proceedings. This done, the whole work of legislation must be begun anew. No such condition obtains in the other branches. The new officers take up pending matters where 
the old officers left off. The offices as offices thus have a continuous existence.

It is not an easy matter to explain how this system came into existence or to justify it from the standpoint of efficiency in its practical operation. The explanation of its rise is found in the belief that at relatively frequent intervals the people should be given an opportunity to determine whom they want to represent them and that their new representatives should have a free hand. It would seem, however, that this could be secured without the provision that the whole work of organizing, adopting new rules, and beginning work anew should be required. This feature, notwithstanding its importance, is not, however, one to which further attention need be given, since it is so firmly established, and so little demand exists for its change, that consideration of it would have only an academic interest.

The question of the precise length of life that shall be given to legislatures and that of the authority of chief executives to bring them to an end by ordering a dissolution of the lower house are, however, matters of direct practical importance. The first of these we have already considered under the heading "Determination of the composition and method of selection of members of the legislative branch." Consideration of the second will be had in the chapter dealing with the organization of the executive branch of the government.

Legislative bodies in still another way have a discontinuous existence. With few or no exceptions legislatures break up their proceedings into what are known as sessions. Usually provision is made for a session each year. These are known as ordinary or regular sessions. In addition the power is usually granted to the chief executive to summon them in special or extra sessions or for the legislature so to 


\section{THE LEGISLATIVE BRANCH}

assemble on its own initiative. These interruptions are of entirely a different character from those that take place between old and new legislatures. A second session of an existing legislature finds itself fully organized and equipped with rules of procedure, and takes up the work under way where it last left off. The reason for thus breaking up the work of legislatures into sessions consists partly in the fact that the work to be done does not require that legislatures shall remain in continuous session, and partly in order to give an opportunity to legislators to return to their constituencies and look after their interests in respect to securing a reelection to office. In the individual states of the United States the amount of work falling upon the legislative branch is so small that in many states legislatures convene only every other year and remain in session for only a couple of months or so. In the case of our national government, however, the burden of work falling upon this branch in recent years has been so great that Congress has remained in almost continuous session throughout the year.

Determination of the Powers and Privileges of Legislatures.-A very special class of questions that has to be solved in providing for the organization of the legislative branch of government is that of the special powers and prerogatives that shall be conferred upon it and its members in order that they may properly perform their duties. These powers and prerogatives, or privileges, as they are sometimes called, have for the most part to do with the matter of ensuring independence on the part of the legislature. For centuries, indeed during the greater part of its history, the English Parliament had to wage a bitter struggle against the King to prevent the latter from, not only interfering with its work, but of arresting and sending to execution those members who opposed too strongly his wishes. 
The whole question of political liberty was at stake. To secure its independence, Parliament found it necessary to insist upon the recognition of its possession of certain fundamental powers and privileges. Among these the most important were the right to choose its own officers, to formulate its own rules of procedure, to be the judges of the elections and qualifications of its own members, to control the conduct of its members by disciplinary measures and, if need be, to suspend or expel them, to enjoy liberty of speech, that is, not to be subject to judicial or other proceedings for any of their utterances in the performance of their duties, and to be free from arrest while Parliament was in session.

The possession of all of these powers and privileges by a legislature is now generally recognized as essential if that branch of the government is to enjoy freedom of action and immunity from undue control by the executive and judicial branches of government. Provision for all of these is thus found in the constitution of the United States and the individual states, and is also generally found in the constitutions of other States having a popular government.

There are two other powers enjoyed by legislative bodies, the scope and character of which are not so clearly established. These consist in the right of the legislature to compel the attendance of, and giving of testimony by, private individuals when information is desired by that body, and in making similar calls upon the executive. In respect to the first, the matter at issue is, not so much the right, as the means that may be employed, in compelling compliance with its wishes. In respect to the latter, it is now generally recognized that, in the case of the government of the United States at least, the President may refuse to comply with requests for information if he deems that the giving of such information will be prejudicial to the public welfare. This 
applies especially in respect to all matters falling within the scope of his executive powers.

Determination of the Methods of Procedure of Legislatures.- Of the several heads under which the organization and administration of the legislative branch of government is being considered, none is of greater importance than that of the determination of the methods that shall be employed by that branch in the performance of its duties. The manner in which a legislative body organizes itself and the rules that it adopts to govern its proceedings determine in no small degree the character of the governmental system resulting. This is strikingly illustrated in the case of the English government. A study of that government shows that its most essential features, the manner in which the ministry is selected, the dependence of that organ upon having a majority in the House of Commons in order to continue in office, and its control over legislation, indeed the whole system of Responsible Government, are but matters of legislative organization and procedure. It is hardly going too far to say that the system of government that England now has, has come into existence as the result of the Parliament determining the organization that it shall have and rules that shall govern its proceedings.

Though this is not equally true of governments whose general character has been fixed in written constitutions, the matter of legislative organization and procedure adopted by them will nevertheless be found to be of supreme importance in determining the character of government actually resulting. Certainly this is so of our own government. If one were seeking to point out the most important features of our government in its practical operations, a leading place would have to be given to such features as: the position and powers of the Speaker of the House; the organization of 
the two houses in committees; the rules and conventions governing the selection of these committees and determining their powers; the character and functions of such organs as the Committee on Rules of the House, the Steering Committee of the Senate, and Legislative Caucuses in the formulation and adoption of legislative programs; and the whole procedure that has been adopted for the initiation, consideration and taking of action upon legislative proposals. All of these are matters of legislative organization and procedure.

A most important aspect of these fundamental features of our government is that only in slight degree are they ones determined or regulated either by the constitution or statutes. For the most part they exist, and the methods of their operation are determined, by rules adopted by the two houses and by conventions which, though unformulated, yet have controlling force. The whole system of congressional organization and procedure as it now exists is thus one of gradual evolution. It is one moreover which is constantly. undergoing change. But a few years ago the Speaker of the House occupied a position of power far superior to that which he now has. The development of the dominant position now occupied by the Committee on Rules of the House in determining what measures shall receive consideration and the conditions under which such considerations shall be had is a comparatively modern phenomenon. At the present time there is a strong demand for the adoption by the national government of what is known as a scientific budget system. If this is done, a thorough reorganization of the whole system of committees for the consideration of appropriation bills and of procedure in taking action upon such measures will be required.

It is manifestly impracticable for us here to attempt a 


\section{THE LEGISLATIVE BRANCH}

consideration of the details of the problem that is presented in working out a satisfactory legislative organization and procedure. All that can be done is to point out that here exists one of the most important problems of government and that, according as it is worked out in one way or another, the whole character of the governmental system resulting is vitally affected. 


\section{CHAPTER XIV}

\section{THE EXECUTIVE BRANCH}

In considering the executive branch of government, it is necessary at all times to keep in mind the distinction between it and the administrative branch. If this is done, it will be found that this branch, notwithstanding its importance, offers but relatively few problems for solution. This arises from the fact that the field of purely executive duties has now become fairly accurately defined and that such duties require no elaborate machinery for their performance. In point of fact it will be found that this branch consists of little more than the single office of chief executive. In large part, therefore, the problems of this branch consist simply in the determination of the functions of the executive, the qualifications that shall be required of the chief executive, how he shall be selected, by what tenure he shall hold office, the conditions under which he may be removed, etc., and the relations that he shall have to the other branches of government.

The Functions of the Executive Branch.- Though we have necessarily had to consider the functions of the chief executive in our consideration of the classification of governmental functions and examination of the question of the union or separation of powers, it is nevertheless desirable that these functions should again be enumerated in this place. Briefly stated, they are: that the chief executive shall be the titular head of the government, and as such, represent it in all cases where it needs a spokesman; that he shall 
especially represent the government in all of its relations with other States; that, to this end, he shall be the commander-in-chief of the armed forces of the government; that he shall be the officer to exercise the quality of mercy as evidenced in the power to grant reprieves and pardons; and, finally, that he shall have the general duty of seeing that the laws of the land are duly enforced.

These are the powers or functions that are very generally deemed to fall within the executive branch of government. All of them are enjoyed by the chief executive of the United States. There are, however, certain other powers possessed by chief executives of other governments that are of great importance. Among these, much the most important is that in respect to the power of the chief executive to summon, prorogue, or dissolve the legislature. This is a matter of such importance that it is given special consideration where the subject of the relations of the chief executive to all other branches of government is taken up.

The Office of Chief Executive.- In all governments it has been found desirable, if indeed it is not indispensable, that the executive powers shall be legally or nominally vested in a single person. The nearest departure from this practice is found in the governments of England and Switzerland. In the former of these two governments, the possession and the actual exercise of the executive powers are carefully distinguished. Legally the King is the possessor of all executive authority and all executive acts must be performed in his name. Actually, however, the ministry of the day decides how this authority shall be exercised. To use an English expression, the office has, as it were, been put into commission. In Switzerland, provision is made for a chief executive, known as President. Actually, however, this officer must exercise his authority in accord- 
ance with the wishes and instructions of the Assembly. The system resulting is thus one analogous to that of England. The best example of the executive power being both vested in, and actually exercised by, a single chief executive is afforded by a monarchy of the autocratic type. Among Popular Governments the leading example of such a union of possession and exercise of this power is undoubtedly afforded by our own government. Though, as we will see, the President is subject to a certain measure of control in respect to the performance of certain of his executive powers, his personal individual powers in this field are enormous. There are indeed few chief executives having greater power in this respect.

In this connection it is of interest to note that one of the great elements of weakness of the government established, after our Declaration of Independence, under what were known as the Articles of Confederation, was the failure to provide, in that scheme of government, for a chief executive. The troubles resulting from this failure undoubtedly were largely influential in bringing about such a large and definite grant of executive powers to the President in our present form of government.

Qualifications of Chief Executive.- The matter of the qualifications required of persons in order that they may hold the office of chief executive is one giving rise to little or no trouble. When this office is filled by hereditary descent, the only additional qualification required is usually that of sex. In some cases only males, and in other cases, both males and females, meeting the required conditions in respect to descent are eligible. If the person so entitled to office is a minor under a certain age, provision, however, is usually made for the selection of a regent to act for him or her until he or she becomes of the required age. The quali- 
fication of mental capacity indeed is not usually required, such cases being met by the selection of a regent as in the case of a chief executive who is under age.

In the case of governments whose chief executives are selected by some method of election, the qualifications required rarely go beyond those of sex, age, nativity and citizenship. In our own government the only qualifications required are that " no person except a natural born citizen or a citizen of the United States at the time of the adoption of this constitution shall be eligible to the office of President; neither shall any person be eligible to that office who shall not have attained the age of 35 years and been 14 years a resident within the United States."

Method of Selection of Chief Executive.- Undoubtedly one of the most important problems presented in providing for the exercise of the executive power is that of determining the method that shall be employed in selecting the chief magistrate. In respect to this the issue in the first place lies between the two methods of: selection in accordance with some hereditary principle; and selection by some method of election. It is not our intention to consider the relative merits of these two systems. It may be stated, however, that strong arguments can be advanced in favor of both. The greatest argument in favor of the first lies in the fact that this most important act is definitely determined in accordance with fixed principles and is thus taken out of the domain of popular strife. If one surveys the history of Popular Government since its widespread development in the nineteenth century, it will be found that the system of selecting a chief magistrate by some method of election has, in the case of the majority of nations, given rise to acute disturbances and often to bloodshed and revolution. The experience of Mexico and other Latin-American 
countries in this respect furnishes the most striking examples of this. The difficulties inherent in this method are such that it is a question whether it is possible to devise a system of election that will give good results in practice in a country which has not reached an advanced stage of political development. It was due to an appreciation of these difficulties that the abortive attempt of Yuan Shi Kai, the late President of China, to convert the government of that country from a Republic to a Constitutional Monarchy was looked upon by many as a step calculated to stabilize political conditions in that country.

The great objection to the system of selection by hereditary descent is the uncertainty as to whether a competent person will be secured in this way. The importance of this consideration is very much lessened where the chief executive, as under the English system, is only nominally the custodian of executive authority, the real exercise of this authority being in a body otherwise selected. It is due to this that the English hold that their monarchical system has all the advantages of the system of an elected chief executive with none of its disadvantages.

This question of the relative merits of the hereditary and elective systems of selecting a chief executive is, however, one now having little more than an academic interest for those peoples who have definitely adopted a republican form of government. To them the idea of a monarchical government is so distasteful that the matter is no longer one of weighing the relative technical merits of the two systems. To such peoples, the problem thus resolves itself into that of the particular method to be employed in selecting a chief executive through a process of election.

Considering the problem from this standpoint, it will be found that, though the systems employed by Republican 
Governments differ widely in detail, they all fall under one or the other of the following three heads: ( $\mathrm{I}$ ) election by popular vote or by what is known as a plebiscite, (2) election by the legislature, (3) election by a special electoral college. A few words will be said regarding each of these methods.

Election " of Chief Executive by Popular Vote or a Plebiscite. - The election of the chief executive of a government by popular vote would seem to be the method most logically to be followed by a people having adopted a government resting upon the principle of popular sovereignty. It is the one which we would, therefore, expect to be followed unless grave practical objections can be brought against it. In point of fact this is the method that is usually employed in the selection of the chief magistrates of all the subordinate units of a Popular Government, such as constituent states, municipalities, etc. To a considerable extent it is even employed in respect to such units in monarchical and autocratic governments.

When, however, we turn from such subordinate governments to general or central governments we find no modern States, except possibly those of Latin-America, making use of this system as its legally established system. France adopted this system in the establishment of the Second Republic in 1848 , but abandoned it in the establishment of her Third Republic in $187 \mathrm{I}$. Her reason for doing so was that Louis Napoleon made use of this system, first to secure his election as President, and later to secure an endorsement of his coup d'état by which he made himself Emperor. The system, it was held, lent itself to the creation of a dictatorship and the overthrow of the system of Republican Government.

There can be no doubt that it was due to considerations such as this that led to the definite rejection of this system 
by those responsible for the framing of the government of the United States. We have pointed out that the framers of our constitution were as solicitous of avoiding what were believed to be the dangers of a Democracy as they were those of an Autocratic Monarchy. The election of the chief executive by popular vote they looked upon as essentially a democratic device, as one calculated to divide the country into hostile parties, and as giving rise to the danger that a President once elected might use this method of appealing to the people to perpetuate himself in power. Due to this, they devised the peculiar method of selecting this officer which will be described when we consider the third method of election, that through the use of a special electing body or electoral college, as it is more technically known. In point of fact this intention on the part of the framers of our constitution has been completely defeated, since the system thus created has been so worked in practice as to establish what is in effect a system of election by popular vote. If one considers the American system as it actually exists in working operation, it is, therefore, one of election by popular vote.

Election of Chief Executive by the Legislature.- The second system of selecting a chief executive by a method of election is that of entrusting the election to the legislature. This system, while having a less democratic character, is thoroughly consonant with the principles of Representative Government, since the persons constituting the legislature have been elected by the people, and in this duty act as the representatives of the latter in the same way as they do in performing their legislative duties. This is the system that is now followed by France and Switzerland. There can be no doubt that it has given excellent results in practice. In 
those countries the election of a President takes place with little or no popular disturbances.

Election of Chief Executive by a Specially Constituted Electoral College. - The third method of selecting a chief executive through an elective process is that of entrusting this duty to a specially constituted body known as an electoral college. This is the system which legally exists in the United States. The provisions of the constitution relative to this are: that each state shall appoint, in such manner as its legislature may determine, a number of electors equal to the total number of Senators and Representatives to which it is entitled in Congress; that these electors shall meet in their respective states and vote by ballot for President and Vice President; and that the result of such balloting shall be forwarded to the President of the Senate of the United States, who shall open and count such ballots in the presence of the Senate and House of Representatives jointly assembled and declare the result. The person securing the greatest number of votes cast for President, if a majority of the votes cast, is declared elected President, and the person receiving the largest number of votes cast for Vice President, if a majority of the votes cast, is declared elected Vice President. If no person receives a majority of the votes for President, the House of Representatives must thereupon proceed to the election of a President from among the three persons receiving the largest number of votes; and if no person receives a majority of the votes cast for Vice President, the Senate must make a selection between the two receiving the largest number of votes for that office. The House in making the election of President must vote by states, each state having one vote, and the votes of a majority of the states are required for election. 


\section{THE GOVERNMENT OF MODERN STATES}

We have already pointed out why the framers of the constitution rejected the method of selecting a President and Vice President by popular vote. The method of having these officers elected by Congress, except as a last resort, was rejected because they deemed that this would do violence to the separation of powers upon which they laid great stress. They feared that if the President and Vice President owed their positions to Congress, they would not have the independence of that body which in their opinion it was desirable that they should have.

In practice, as has been pointed out, the intent of the framers of the constitution in respect to having the President and Vice President elected by a special body composed of the wise men of the country, and using their best judgment in respect to who were best qualified to fill those offices, has been wholly defeated. This arose in the following way. In the first place the states uniformly adopted the method of having their presidential electors elected by popular vote. The several political parties thereupon adopted the practice of putting in nomination as candidates for this office persons who were pledged in advance to cast their votes, if elected, for the nominees of the parties for President and Vice President. The result was to establish what is in effect the system of selecting a chief executive by popular vote, the vote, however, taking place by states instead of by the country as a whole. In consequence of this latter provision, it sometimes happens that a President is elected who has received only a minority of the total number of votes cast by the people.

Succession to the Office of Chief Executive.- Where a chief executive holds office by hereditary right the question of succession in case of the death of the incumbent is automatically solved. This feature indeed constitutes the chief 
advantage of that method of selection. Where he is elected by the legislature, the problem of succession to office is also a comparatively simple one, since the legislature can always be promptly assembled to elect a new incumbent. This also is one of the advantages of that system. Where the chief executive is elected by a popular vote, or by an electoral college involving a popular vote, such as is the case in our government, the matter of succession in the case of the sudden death or physical disability of the chief executive, is of great importance. In respect to this matter the constitution of the United States provides that " in case of remeval of the President from office, or of his death, resignation or inability to discharge the powers and duties of the said office, the same shall devolve on the Vice President and the Congress may by law provide for the case of removal, death, resignation or inability, both of the President and Vice President, declaring what officer shall then act as President and such officer shall act accordingly until disability be removed or a President shall be elected."

This provision has not been found to be satisfactory in all respects. For one thing, it failed to make provision for case of a failure on the part of the House of Representatives to elect a President when the election was thrown into that body. This omission was corrected by the Twelfth Amendment adopted September 25, I804, which, among other things, provided that " if the House of Representatives shall not choose a President, whenever the right of choice shall devolve upon them, before the Fourth day of March next following, then the Vice President shall act as President as in the case of the death or other constitutional disability of the President."

Again it failed to specify what organ should be the judge as to when a President shall be deemed to be unable to dis- 


\section{THE GOVERNMENT OF MODERN STATES}

charge the duties of his office. This case arose concretely when President Garfield lay for so long a time physically incapacitated for the discharge of his duties as President as the result of an assassin's bullet. There being no organ competent under the constitution to declare his inability he continued to remain President until his death.

The provision that the Vice President shall succeed to the office of President in case of the death or removal of the President is unsatisfactory since it rarely happens that a Vice President has been selected with a view to this contingency. Often he has been selected as a matter of political expediency to placate a minority or dissident wing of the party. When Johnson succeeded to the Presidency upon the death of Lincoln he found himself completely at outs with his party, the friction at last becoming so great that impeachment proceedings were brought against him and he only failed of impeachment by a single vote.

The matter of succession to the Presidency in case of the death, removal or disability of both the President and Vice President has been settled by law in different ways at different times. The law now in force was adopted in 1886 and fixes the succession in the following officers in the order named: Secretary of State, Secretary of the Treasury, Secretary of War, Attorney-General, Postmaster General, Secretary of the Navy, and Secretary of the Interior. This order corresponds to the chronological order in which these offices were created.

The Independence of the Chief Executive in the Performance of his Executive Duties. - In distinguishing between executive and administrative powers we have pointed out that what distinguishes the former from the latter more than anything else is that they are essentially of a discretionary character, while the latter involve no such quality 
except in respect to the particular means to be employed in putting into execution decisions already arrived at. It follows from this that the executive should be given a large measure of independence, if not complete independence, in the discharge of these functions. Certainly this is so when the government is one of a separation of powers. This means that neither the legislative nor the judicial branch shall have the power either to direct the executive how he shall discharge these duties or to hold him to account for the manner in which he does so. This, however, does not prevent the provision in a constitution that certain acts shall not be deemed to fall within the executive power, or that certain of the powers possessed by the executive may only be exercised in conjunction with, or upon the approval of, the legislature.

Under our government the only limitations upon the President in the exercise of his executive powers are that war can be declared only by Congress and that the making of treaties with foreign powers and certain specified appointments shall be done by and with the advice and approval of the Senate. With these exceptions the President has complete independence in respect to the exercise of his executive as distinguished from his administrative powers. In his hands alone lie the conduct of foreign relations, the decision in respect to the negotiation of treaties, the recognition of the governments of foreign States, and the reprieve or pardon of persons convicted of crime against the United States. Any attempt on the part of Congress or the courts to dictate to or control him in the exercise of these powers is without avail. Repeatedly Congress has attempted to exercise a voice in determining the conduct of foreign affairs by the passage of resolutions providing for the recognition of some foreign government, or the taking of some other action 
in the field of foreign relations. Invariably the President has ignored such action and has stated that he did so since his recognition of it would represent an acquiescence on his part in an infringement of the constitutional rights of the executive.

In respect to the waging of war, while the President cannot declare war, that being a duty entrusted to Congress, he can recognize that a state of war exists. This he did in the case of our great civil war. Furthermore, he can so formulate foreign policies and direct acts to be done as will make war almost inevitable. The sending of troops into Mexico in the pursuit of the bandit, Francisco Villa, and the occupation of Vera Cruz by the American army are recent examples of the extent to which the President may take action of a belligerent character upon his own iniative and judgment and without any declaration of war on the part of Congress.

After war has actually broken out, the powers of the President as commander-in-chief of the armed forces are almost autocratic in respect to the determination as to how military operations shall be carried on, and what other things shall be done as a necessary feature of making these operations successful. The exercise of these-powers, however, is subject to the limitation that the determination of what armed forces shall be provided and the voting of the money necessary for the prosecution of military operations rest with Congress, as a part of its general legislative function.

Relations of the Chief Executive to the Other Branches of Government.- Of all questions having to do with the Executive Branch none is of greater importance than that of the relations that shall exist between the chief executive, constituting this branch and the other branches 
of government. This is a subject which has necessarily been touched upon in our consideration of the classification and the union or separation of government powers. It will also have to receive consideration in our treatment of the judicial and administrative branches. It may here be stated, however, that in respect to the administrative and judicial branches the function of the chief executive as chief executive consists simply in seeing that the laws regarding, or to be administered by, those branches are duly enforced. As will hereafter be pointed out, in most governments and especially in our own, the chief executive has been given the general status and powers of an administrator-in-chief. Where this has been done we have in effect the same person holding two offices. As administrator-inchief the person holding the office of chief executive plays a dominant rôle in the work of the administrative branch. In doing so, however, he does not do so in virtue of any inherent powers as chief executive, but merely because the legislative branch, in which final authority in respect to the organization and work of the administrative branch is vested, has, as a matter of policy, made of this officer one to serve in this capacity.

When we turn to a consideration of the relations that exist, or may exist between the chief executive and the other two branches of government, the electorate and the legislature, we are confronted with issues of great importance. These issues center around the question as to whether the responsibility of the chief executive for the manner in which he discharges the duties of the office shall be directly to the electorate or to the electorate through the legislature. According as one or the other of these two principles are adopted, different types of government are brought into existence to which have been given the desig- 
nations of "Presidential Government," and "Responsible Government."

The Presidential Type of Government.-That type of Popular Government known as a Presidential Government results where the chief executive is deemed to dërive his powers directly from, and be accountable directly to, the electorate. The leading example of such a government is that of the United States. Under this form of government the chief executive is not dependent upon having the support of the legislative branch for continuance in office. It may happen, and in our government often does happen, that the chief executive and the legislature are not in accord in respect to their general policies or governmental programs, and that the chief executive may hold his office in virtue of the support of a political party different from the one to which the majority of the members of the legislature belongs.

The Responsible Type of Government.-What is known as a Responsible Government exists when, in a Popular Government of the Representative Type, the principle is established that the officer or officers actually exercising the executive power shall at all times have the support of at least the lower or popular chamber of the legislature, as a condition to their remaining in power. A condition precedent to the operation of a government of this type would seem to be the establishment of the system, heretofore described, of having the executive power, from the legal standpoint, vested in the hands of a titular chief executive, while its actual exercise is in the hands of another body known as a ministry. Leading examples of this form of government are the governments of England, France, Italy and many other countries of Europe. In these governments the ministry usually is composed of the heads of the more 
important administrative departments and are at the same time members of one or the other of the. two houses of the legislature, or at least have power to be present and to participate in the proceedings of those bodies. In them, in fact, we have a union of legislative, executive and administrative powers in the same hands. It is thus common to speak of the ministry in power as the "Government."

This "Government," as has been stated, can only remain in power so long as it has the support of the popular branch of the legislature; that is, all of its measures of importance must, upon a test vote, receive a majority of the votes cast. Defeat on any such vote is deemed to be a vote of lack of confidence and the ministry thereupon must place its resignation in the hands of the titular or legal chief executive. It then becomes the duty of that officer to select some other person who will undertake to form a new ministry that will receive the support of the popular chamber. In making this selection of a "Premier" the titular chief executive may, or may not, according to circumstances, have some discretion in respect to whom he shall choose. If what is known as the Two Party System of political parties obtains, his choice is practically limited to the leader of the opposition party in the House. When the Multi-Party System obtains, and when consequently a majority may be secured through various combinations of parties, no one of which has a majority, the titular chief executive may have some considerable degree of discretion in making his selection. Under these conditions it often happens that several men in turn are entrusted with the task of forming a ministry before success is achieved in finding one who can form a ministry that will receive the support of the House.

To the statement that a ministry, to remain in power, must at all times have the support of the popular chamber, 
one important exception must be made. In England, whose government is the leading example of this type of government, a ministry, upon being defeated in the-House, can, if it believes that the adverse vote does not correctly interpret the will of the electorate, appeal to the latter. This it does by recommending to the titular executive, the King, that he dissolve the House and order the election of a new one. This recommendation, under the English political system, is one that the King cannot refuse to comply with. This feature must be considered in connection with another fundamentat principle of the English system. This is that members of the House of Commons are elected under what amounts to an imperative mandate from their constituencies to support in all cases one or the other of the political parties. It results from this that a ministry taking office with a majority of the House at its back is rarely defeated in the House. Few changes in a ministry thus take place except as the outcome of a general election. It will thus be seen that on final analysis it is the electorate that determines the ministry that shall hold power.

It should furthermore be noted that it devolves upon the ministry in power and the opposition, or the ministry out of power, as the opposition under the Two Party System is" sometimes termed, to formulate their political programs. Actually, therefore, the House of Commons is not the body which formulates governmental programs, or even holds the ministry in power to account. The responsibility of the ministry to it is thus more formal than actual. The English system is none the less one of Responsible Government. It is, indeed, the highest type of that form of government, since, in its practical operation, responsibility is to that body to which it should be, if the principle of Popular Government is to find full expression. 
France, no less than England, has a Responsible Government. This government, however, works in a different way from what it does in England, due to the fact that it has not developed the features which we have just been describing as parts of the English system. In the first place the French constitution provides that the lower house, or Chamber of Deputies, as it is called, cannot be dissolved by the chief executive except upon the consent of the upper house, the Senate, being secured. In practice this has meant that the power of dissolving the lower house is rarely, if ever, exercised. Effective means are thus lacking by which a defeated ministry can, if it desires, appeal from the decisions of the House to the electorate. In the second place, France has not evolved a Two Party System of political parties. Most ministries come into power through the effecting of a coalition between a number of parties, no one of which has a majority, and are frequently defeated in the lower house by a regrouping of parties or factions within such parties. Changes of ministry thus are of frequent occurrence as the result of voting within the House and without any new expression of opinion by the electorate. The responsible government of France is thus one of real responsibility to the legislature, and only very indirectly to the electorate.

Before leaving this subject of the responsible type of government, two matters of general interest should receive attention. The first is that all governments having a President as their chief executive are not Presidential Governments, as that term is technically employed; or, to state this in another way, it is as possible to have a Responsible Government in a Republic as it is in a-Monarchy. The second is that most peoples who are now trying to pass from an Autocracy to a Popular Government are seeking to do 
so by establishing the principle of Parliamentary Responsibility. This is especially evident in the case of the two leading Autocracies of the world, Germany and Japan. In the former country the formal declaration has been made by the Chancellor that the principle of parliamentary responsibility on the part of the Chancellor and other ministers of the Crown will hereafter be observed, and that steps will be taken so to amend the imperial constitution as to make this possible. ${ }^{1}$ In Japan the struggle for a recognition of this principle has long been a dominant feature of her politics and the new ministry just created is said to be the first one to be formed resting squarely upon that principle.

Comparison of the Two Systems.- That much attention should have been given to the relative merits of these two widely divergent systems of government is evident. Each has its ardent partisans. It is exceedingly difficult, however, to weigh the merits of the respective claims that are put forward. This arises from a number of facts. The first is that this feature of government cannot be dissociated from other features of government and considered alone. Especially must attention be given to the important question of the separation or union of powers.

One of the great advantages claimed for the system of Responsible Government is that it ensures that the three great branches of government, the legislative, the executive and the administrative, will at all times be in accord. No one can deny the validity of this claim. One has but to contrast the conditions obtaining under the English system of Responsible Government with those obtaining under our own system of Presidential Government. Under the

1 Address of the Chancellor, Prince Maximilian, before the Reichstag, October $5,1918$. 


\section{THE EXECUTIVE BRANCH}

English system, it is impossible for the three branchies to be in disaccord. With us it is almost a matter of chance if the executive and the legislature are of the same political complexion; and cases are constantly arising where a President is not even in accord with the members of his own political party in Congress. The result is that neither the President nor Congress is able to carry out his or its policies unless the latter body should be so united that it can muster the two-thirds vote necessary to override a Presidential veto of bills. This condition, however, is not wholly, and possibly not primarily, the consequence of the United States adopting the presidential type of government. In no small degree it is due to the fact that different terms of office have been given to Senators, members of the House and the President; Senators being elected for six years, the President for four years, and members of the House for two years. Were the provision made that all should have a uniform term, and be elected at the same time, it would be quite possible to have a government in which both branches would be of the same political complexion and pledged to the same general program.

Another advantage claimed for Responsible Government is that such government at all times corresponds to the desires of the electorate as expressed directly or through its representatives in the legislature; since at any moment the ministry may be defeated and one conforming more to popular desires be substituted in its place. This is an advantage, however, which is more theoretical than actual. In England, as we have seen, a ministry is now almost never overturned except as the result of an election. The length of Parliament's term is now fixed at five years; until recently it was seven years. A ministry having a substantial majority upon assuming office as the result of a general 


\section{THE GOVERNMENT OF MODERN STATES}

election thus has an almost assured life of a period greater than that enjoyed by the President and much greater than that enjoyed by the popular chamber of our legislature. The facility with which changes of ministries may be made in countries having a Responsible Government, and not having the party system and political conventions of England, such as France, is moreover not an unmixed blessing. Certainly in those countries it has given an instability to the administration of public affairs that is not found in this country.

Much the most important fact to be given consideration in seeking to make a choice between these two systems is that of the actual conditions to be met and especially the political experiences and capacity of the people concerned. There can be little question that of the two systems the successful working of the system of Responsible Government necessitates a far higher political capacity on the part of the people than is required in the case of a Presidential Government. Responsible Government has worked well only in the case of England, whose people have had centuries of experience in the working of popular institutions. It has worked indifferently in France, and in most other countries has given very unsatisfactory results. As has elsewhere been stated, it was the good fortune of the author to serve for a term as constitutional adviser to China while that country was attempting to establish a new form of government. One of the great issues then at stake was as to whether the Republic that it was being sought to establish should be of the presidential or responsible type. The author had no hesitancy in giving his advice in favor of the presidential type. China had no effective means of formulating a public opinion, no well developed party system. The brief experiment that had been made with Responsible 
Government showed that intelligent control by the legislature of ministries could not be had. Ministries consisted only of coalitions of persons seeking to maintain themselves in power by the distribution of governmental favors among members of the legislature and the exertion of improper influence in other ways. Nothing approaching a really stable government with a carefully formulated and consistently adhered to program was possible under these conditions. It is practically certain also that Responsible Government would prove a failure if attempted in many of the Latin American Republics.

In conclusion it may be said that Responsible Government in England has undoubtedly worked well; and it has many features that should be carefully studied by us in seeking to improve our own government. It is not, however, one that is applicable to all peoples. It is indeed a question whether it will give successful results except where exceptionally favorable conditions are to be found such as exist in England and her great English speaking Dominions. 


\section{CHAPTER XV}

THE JUDICIAL BRANCH

Of the several branches of government none has received so little attention at the hands of students of political science as the judicial branch; yet none is of greater political importance to the individual or more in need of critical examination. To us in the United States this is especially so since both our system of courts and their methods of procedure are far from satisfactory. In their practical operation they are expensive both to the government and to litigants; they perform their work with great dilatoriness; and miscarriages of justice are frequent.

The Functions of the Judicial Branch.- To understand the part played by the judicial branch in the political system of a country, and the problems that are presented in providing for its organization and administration, it is desirable to start with a somewhat more accurate idea of the functions performed by courts than generally obtains. In popular estimation courts do little more than one thing: decide disputes. 'This, however, is a very superficial view. If one looks below the surface it will be found that, in deciding disputes, courts do a number of important things other than that of the settlement of particular controversies. Analysis of the work done by them shows that they in fact do the following five things:

I. Investigate and determine facts.

2. Apply the law to the facts as thus determined.

3. Determine and construe law. 
4. Prevent the infraction of law and the violation of rights.

5. Administer property.

Courts as Bodies to Investigate and Determine Facts. - It is very important to distinguish between the work done by courts in investigating and determining facts, and that done in interpreting and applying the law to these facts. In the great majority of cases coming before courts, whether of a civil or criminal character, the law involved is clear and no legal issue is presented. The task confronting the court in such cases is thus simply that of determining facts. The desirability of distinguishing the fact-determining function of courts from their other functions lies in the fact that courts in most countries, and especially in England and the United States, have developed a very special procedure in its performance. This procedure consists in treating the inquiry practically as a duel, in having the two parties bring forward witnesses to testify in support of their respective contentions and in having the court itself reach a decision through a weighing of the testimony thus produced. The system, in a word, is one where the burden of bringing out the facts is thrown almost wholly upon the parties to the contest. The whole inquiry is given an intensely partisan character. Even the witnesses, whether they have any interest in the case or not, are supposed to be witnesses for one side or the other. The court itself assumes little or no responsibility in respect to seeing that all available evidence is produced. It makes no investigation itself, summons no witnesses. Furthermore, in carrying out this system of fact determination, it has formulated an elaborate set of rules to govern the parties in producing witnesses and subjecting them to interrogation. The court itself thus occupies practically a neutral position, confining 
its action almost wholly to seeing that the rules of the game are followed by the contestants.

This system is in marked contrast to that pursued by an administrative body in seeking to determine the facts upon which to base its action. Such a body itself determines the character of the facts deemed necessary in order to arrive at a proper decision. It provides itself with a staff of investigators which, acting under its constant direction and supervision, secure the data needed. It does not tie its own hands by formulating rules of procedure to which it is bound to make its action conform in all cases. It thus takes direct charge of an inquiry and assumes full responsibility for its prosecution.

We have contrasted these two methods of inquiry, the judicial and the administrative, since there is evidently here presented a difference of method of the utmost significance. The making of a choice between them constitutes one of the problems that is presented in determining the organization and methods of procedure of the judicial branch of a government. Only by segregating this fact-determining function from the other functions performed by a court can the special character of this problem be made clear.

In the case of our. own judicial system this problem is all the more important since this function of determining facts has, in the case of certain classes of controversies, not only been carefully segregated, but use is made of a special organ for reaching a decision in respect to such facts. This special organ is the Petty Jury. This jury consists of twelve men who are specially empaneled for each case to sit as a board for the hearing of the testimony and, on the basis of such testimony, of finding the facts. Here again a very grave question is presented as to whether the use of such an organ can be justified by the results that are ob- 
tained under it. The issues that are here involved go to the very foundation of our system of judicial administration. They have received and are receiving great attention and the literature regarding them is voluminous. Into the relative merits and demerits of the system in force we cannot here enter. All that we can do is to state the issue as one of the important problems of judicial administration.

Courts as Bodies to Apply the Law to Ascertained Facts.-With the facts determined, the next step in the work of courts is to determine the action that shall be taken upon such facts. This is performed by courts in rendering what is known as decisions. In them the courts decide what is the application of existing law to such facts. In doing so they may exercise a certain discretion, though the limits within which such discretion may be exercised are usually carefully defined by the law. Here again it is important to distinguish between the principles governing a court in the performance of this function and those governing a non-judicial body. It has been accurately stated that the function of a court is to administer law, not justice. The court is not a free agent. It cannot form its decision in accordance with what it may believe will most nearly conform to absolute equity or justice in the particular case under consideration. It is bound absolutely by the law. All that it can do is to declare what the law provides shall be done where a given set of facts is determined to exist. Administrative bodies are not bound in anything like the same way. They are much freer to make their decisions of a character more nearly conforming to justice or expediency. It is not intended by any means to convey the impression that the latter method is the one that is superior to the former in the settlement of the classes of controversies coming before courts. It is merely desired to point out 
that here is a choice of principles which constitutes one of the distinct problems of judicial administration.

Courts as Bodies to Determine or Construe Law.In considering the function of courts as bodies to apply the law to particular cases we have assumed that no issue is presented as to what the law is and its applicability to the case at bar. Unfortunately there are many instances where this condition does not obtain. Laws necessarily must be general in character. In many cases they are so worded that it is difficult to determine their exact meaning. With constantly changing conditions, issues are presented which were not considered when the laws were framed. Laws are not always consistent with each other, and doubt often exists in respect to which of two provisions, or which of two laws, should govern in a particular case. It results from this that courts have the very important function of determining what the law is, what its scope and meaning, and, when there is an apparent conflict between provisions and laws, which shall prevail.

This is a function of supreme importance in any country, but particularly so in England, the United States and all countries which have inherited from the former country her system of jurisprudence known as the "common law." In these countries the law regulating the relations between individuals has been reduced to formal statutory form to but a comparatively slight extent. For the most part this law has come into existence as the result of a long line of decisions of courts in passing upon specific cases. Under the doctrine of what is known as stare decisis, a final decision made by a court is deemed to be of controlling force in all similar or analogous cases thereafter arising. Especially is this so when the same decision has been repeatedly made or affirmed by a long line of decisions. It results 
therefore that a great part of what is known as private law is to be found authoritatively expressed only in the decisions of courts, as embodied in the thousands of reports in which these decisions are published. Under these circumstances the function of courts in determining what the law is is a correspondingly important and difficult one. Growing out of this situation of affairs there has long been an acute controversy among students of jurisprudence as to whether courts are agencies for making law or merely declaring law. The issue is one which lends itself to many subtile distinctions into which we cannot here enter. It is sufficient to say that they do determine the law that exists at any given time.

This function of determining the law in its practical application is, however, one that must also be performed by courts in respect to that law which is in statutory form. Laws in this form are, as stated, necessarily very general in character. Thus, for example, a law having for its purpose to safeguard individual workers from accidents, may, and usually does, go little further than provide that all employers in dangerous trades and industries shall take due precautions to safeguard all dangerous machinery and so to conduct their enterprises as to ensure that their employees are not subjected to unnecessary or undue risk of injury. It is a physical impossibility to specify in detail in the law which industries shall be deemed to be dangerous, what machinery shall be safeguarded and what regulations governing the work shall be enforced. The best that can be done is to insert such general definitions and provisions as will make clear the intent of the law. It thus devolves upon the courts to determine in each case whether the industry involved is, or is not, a dangerous industry within the intent of the law, whether the piece of machinery caus- 
366 THE GOVERNMENT OF MODERN STATES

ing the accident was one that should have been safeguarded, and whether the regulations in force were adequate. The courts thus amplify law and determine its scope and applicability to specific cases. In doing so they act in a quasilegislative capacity, doing that which legislatures should do if they were able.

Another important way in which courts determine law is in resolving conflicts of laws. All laws are not of equal status or controlling force. Most laws emanate from bodies exercising only a delegated authority. It thus becomes necessary in many cases to determine whether the body exercising delegated authority has acted within the scope of its authority in enacting a certain law. The highest law in the United States is that contained in the constitutions of the United States and the several constituent states. Next in rank is that contained in the statutes enacted by Congress and the legislatures of the several states. Then follow the laws or ordinances of political subdivisions, such as municipalities, counties, etc. In the case of all of these subordinate bodies, the scope of their legislative powers is determined by the constitution or by the organic acts authorizing their establishment and operation. Questions are consequently constantly arising as to whether laws enacted by such bodies are within the scope of their powers, whether they are not in conflict with provisions of the superior law. Manifestly the power to determine questions such as these must be vested somewhere. In the United States the exercise of this power has been assumed by the courts. This assumption of power has, however, been bitterly criticized by many. It is claimed that, by so doing, courts have placed themselves above the legislative branch and have made themselves the dominant organ in determining what legislation shall be had. It is pointed out that the author- 
ity so to act has not been expressly conferred upon them by the constitution and that in other States the courts have assumed no such function. The issue here presented is an important one. Into its merits we cannot here enter. It is necessary, however, to recognize that in the United States one of the most important functions performed by courts is that of passing upon the validity of laws, or to use the expression commonly employed, their constitutionality.

Courts as Bodies to Prevent Infractions of Law and Violation of Rights.-Another function performed by courts is that of serving as organs to prevent infractions of law and the violation of rights. Originally courts had no such function. Gradually, however, courts, in England and the United States at least, took the position that it was not necessary that private parties should wait until their rights had been actually violated before they could appeal to the courts for protection; that if such persons had reason to believe that attempts would be made to violate their rights they could appeal to the courts and the latter would thereupon issue orders prohibiting such attempts or at least restraining their commission until the rights of the parties were determined. The orders so issued are known as "restraining orders " or " injunctions." Compliance with such orders is enforced by courts through the power which they possess of ordering the arrest or fine of persons who are guilty of disobeying orders of the court. This power is that known as the power to punish for contempt of court.

This power of issuing restraining orders and injunctions, of deeming persons guilty of disobeying them as guilty of contempt of court, and of imposing penalties for such contempt, is one which has been greatly criticized. There can be no question that in years past it has been exercised by 
courts in an entirely unjustifiable manner and particularly so in controversies arising between employers and their employees. Courts have not been content to issue orders directed to particularly designated parties, but have issued what are known as "blanket" injunctions directed to all parties, that is, to the entire population of the country. This comes pretty close to the exercise of an arbitrary authority. Due to an appreciation of this, legislation has been enacted restricting the powers of courts to issue injunctions and the courts themselves have come to exercise such powers as remain to them in a more conservative manner.

Courts as Bodies to Administer Property.-In many cases where the ownership, use or rights in property are in dispute, courts will take over the administration of such property pending a final adjustment of the points at issue. This occurs especially in the settlement of the estates of deceased persons and where corporations have failed to live up to their financial obligations. In these cases the court appoints an administrator or receiver to take over the property and administer it subject to its orders. Work of this kind is done by courts on a vast scale. There have been times when a very considerable portion of the entire railroad mileage of the country was in the hands of receivers thus appointed and controlled by courts. For all practical purposes the courts have in these cases the functions and duties of boards of directors. The receivers themselves are but officers of the courts; they have no authority other than that granted to them by the courts and their acts must be approved by that body. In handling such property the courts seek, if possible, to adjust all outstanding differences, to settle all outstanding claims, and as soon as solvency is established to return the property to its owners. Where this is not possible they order the winding up of the affairs 
of the corporation, the sale of its property, and the distribution of the proceeds to the persons entitled to them.

In a number of other ways courts at times perform work of an administrative character. They have thus in certain cases had entrusted to them the duty of granting licenses, of nationalizing aliens, of performing marriage ceremonies, of appointing certain officials. All of these duties are known as the "non-contentious" functions of courts. They do not constitute an essential function of courts. They represent merely cases where use has been made of courts as convenient agencies for performing these classes of work.

The Organization of a System of Courts.- Having obtained a general idea of the nature of the duties falling upon the judicial branch we are in a position to consider the problem that is presented in providing organs through which these duties may be performed. These organs are known as courts, or more broadly, judicial tribunals.

One of the first points arising in devising a system of courts is whether such system shall be an integrated or differentiated one; that is, whether a single system of courts shall be established to handle all classes of cases, or whether separate courts shall be established corresponding to the main classes of cases to be handled. In France, Germany, and the countries of Europe generally, a clear distinction has been drawn between disputes between individuals and disputes between individuals and the government or government officers; and a separate set of courts has been established for the adjudication of each. In these countries there is thus found, not only a system of courts corresponding to the ones existing in England and the United States, but another set, known as Administrative Courts, the function of which is to pass upon questions involving the administration of public law. In England and the United States 
no such distinction is recognized. The same set of courts administer both private and public law. Much has been written regarding the relative merits of these two systems and especially as to the extent to which adequate protection of individual rights as against government officers is secured under them. For a long time it was strenuously insisted by English and American writers that a far more effective guarantee of individual rights was secured under the English and American systems. Study of the practical operation of the two systems, however, reveals that this contention can hardly be maintained. Administrative courts in Europe are found to act with as great independence and with as great regard to the protection of individual rights as do English and American courts. Note should further be had of the fact that, notwithstanding the extent to which the distinction between the two systems is insisted upon in the United States, administrative tribunals of a judicial or quasi-judicial character are constantly being created to handle, matters falling in the administrative field. Such, for example, are the U. S. Court of Claims, the Court of Customs Appeals, and various boards and commissions, such as the Interstate Commerce Commission, the Federal Trade Commission, the Shipping Board, the Board of Patent Appeals, etc. ${ }^{1}$

Except for this distinction between ordinary and administrative courts, European countries have integrated systems of courts to a far greater extent than England and the United States, though the former country, as will later be shown, has now gone a long way towards the establishment of such a system. In England until a recent date

1 For a consideration and comparison of the two systems, see Dicey: "Law and Public Opinion in England"; and Goodnow, "Comparative Administrative Law." 
and in the United States at the present time a large numher of distinct courts have been established to handle different classes of cases. There are civil courts and criminal courts, courts of equity and courts of common law, admiralty courts, probate courts, domestic relations and divorce courts. This multiplicity of courts has enormously complicated the work of judicial administration. Many cases arise where it is difficult to determine which court has jurisdiction. These courts differ in respect to their methods of procedure, and the character of the remedies that they can afford. The result is that the administration of justice has become such a technical and complicated matter that it often difficult even for the trained lawyer to find his way.

To correct this condition of affairs England, in the last half of the nineteenth century, put through a series of acts radically reforming her entire judicial system. The most important phase of this reform consisted in bringing together practically all of her courts except those of petty jurisdiction, into one highly integrated system. What had formerly been independent courts became but branches or subdivisions of a single Supreme Court of Judicature.

In the United States conditions of judicial administration are complicated by the existence of two distinct sets of courts, those of the national government, known as federal courts, and those of the separate states, known as state courts. The system of federal courts as regards organization is a thoroughly satisfactory one. The state systems, however, are defective in the extreme. With few exceptions they present all of the evils that obtained in England prior to the reform acts that have been mentioned. There are few measures of governmental reform more urgently needed than that of the recasting of these systems. 
The direction that this reform should take has been pointed out by England. It should consist in the establishment in each state of a single integrated system of courts analogous to that established in England. Fortunately, the need for this reform is now being appreciated. The National and State Bar Associations are actively urging it and there has been established a society known as the American Judicature Society, which has the accomplishment of this reform as one of its main interests.

Another phase of the problem of organizing a system of courts is that of classifying courts according to their relative rank. As a matter of practical expediency it is found necessary to distinguish between what are known as petty courts, that is, courts having jurisdiction over cases involving only minor infractions of law, or where the issue at stake is of minor importance, and superior courts for the trial of cases of serious crime or involving matters of great importance. At the same time it is deemed desirable that provision shall be made whereby decisions in trial courts may be reviewed by superior courts. This is necessary, both that error in such trial courts may be corrected, and that uniformity in the administration of the law by the several courts may be secured. Much difference of practice is here possible in respect to the extent to which this right of appealing from the decision of a lower court to a superior court may be permitted. Many states provide for three series of courts, trial courts, intermediate courts of appeal, and a supreme court, and permit great freedom in appealing from one to the other. While the power to carry a case up from one court to another results in the correction of errors in particular cases, it vastly increases the expenses of litigation and is productive of a corresponding delay in the final settlement of cases. There is a general 
consensus of opinion on the part of students of our judicial system that the right to appeal has been made much broader than circumstances justify; that the effort should be made to provide strong and competent trial courts and make at least their determinations of facts final, appeal being permitted only in respect to matters involving the construction or interpretation of law; rather than in providing for weak trial courts and then making liberal provision for the reexamination of their decisions.

Judicial Procedure.- Scarcely less in importance to that of the system of courts that shall be provided is that of the procedure that shall be made use of by these bodies in performing their duties. This is a problem involving so many technical questions that we can do little more than point out some of the more important considerations that are involved in it.

Some of these considerations have already been mentioned in our consideration of the functions of courts. Among these a matter of prime importance is that of the rôle that the judges should play in the trial of cases. In England and on the continent of Europe the judge assumes a positive direction of cases in a way that he does not in the United States. There is here presented a difference of procedure that is fundamental. The feeling is growing in this country that the English system is the superior one and should be adopted in this country as rapidly as possible.

Another important difference of procedure in judicial systems of different countries lies in the method employed in putting persons accused of crime upon trial. In England and the United States the system is that known as the accusatorial. In all cases of serious crime use is made of what is known as a Grand Jury to conduct an inquiry and determine whether a person accused of the offense shall be 


\section{THE GOVERNMENT OF MODERN STATES}

put upon trial. This jury consists of a number of private individuals, usually twenty-one, who are selected from time to time to sit and examine into accusations of crime. If they deem that a prima facie case exists against any person they "present" or "indict" him. The term "present" is used when the jury acts upon its own initiative and " indict" when it acts upon a case brought before them by the prosecuting attorney. Persons so indicted are then placed upon trial to determine their innocence or guilt. The proceedings of the grand jury are secret and of an ex parte character, in that the accused need be given no opportunity to be heard or to produce witnesses in his defense.

In France and other countries the method is that known as "inquisitorial," and consists in having an investigation of the circumstances of each case made by a special officer who, if need be, proceeds to the place of the crime, takes the statements of persons having any knowledge bearing upon the crime, and in other ways seeks to secure all available evidence. In conducting this investigation the officer gives an opportunity to the persons accused of the crime, or under suspicion, to prove his innocence. If he finds the evidence against any person strong enough to warrant his being held, he orders his arrest. When the trial is had his report is transmitted to the court and constitutes one of the important documents in the case.

Much has been written regarding the relative merits of these two systems. It is claimed by advocates of the latter system that it is superior in that the investigation is made at once by a trained investigator who is a responsible official, and that opportunity is afforded the accused at once to establish his innocence and thus avoid the odium and expense of a trial. Under the grand jury system weeks and months may elapse after a crime is committed before it 
is investigated. In the meantime the accused may be confined in jail awaiting its action. When the investigation is had it is conducted by persons who may never have done such work before and may not be competent to conduct such an inquiry.

Much the most marked characteristic of the English and American system, in contradistinction to those obtaining generally on the Continent of Europe, lies in the distinction made between equity and law, and, in the use of the petty jury for the determination of matters of fact in cases coming under the second head. In England the administration of justice was originally a matter that concerned the feudal lord or the local government. The King had his courts but these were for the trial only of cases in which he was concerned. Gradually, however, by a process of evolution into which we cannot here enter, the King's courts broadened their jurisdiction and in time took over practically the administration of justice throughout the land, the local courts being either eliminated or having their jurisdiction restricted to very petty or special cases. These Kings' courts developed a certain number of forms of action to which persons believing themselves wronged in any manner had to resort. If a man desired to recover possession of land which was wrongfully occupied and witheld from him he brought what was known as an action in ejectment. If he sought to recover an ordinary debt he brought an action in assumpsit, etc. These actions were supposed to cover all cases of private wrongs, each wrong having its appropriate action. After this system became fixed and rigid so that no new actions were originated, cases began to arise where these actions would not apply, or if they did, the remedy that could be secured through them did not meet the necessities of the case. In such cases aggrieved parties 
made their complaints to the King, who turned them over to his Lord Chancellor for action. To handle these cases there thus in time developed a distinct set of courts known as Chancery or Equity Courts. These courts had their own special methods of procedure and gave remedies of a character not to be obtained in ordinary or law courts. It resulted from this that England, in time, found itself with two bodies of law known as "common law" and "equity," two sets of courts, and two systems of judicial procedure and remedies. This system was transplanted to America and is in full force throughout practically all of the states of the Union. No such division of the law and its administration took place on the continent of Europe.

It has been stated that each of these two sets of courts developed its own method of procedure in the trial of cases coming before it. These two systems are radically different one from another. Among their differences, the most important probably is that in courts of equity the judge decides matters both of law and fact, while in courts of law, the judge decides only matters of law, use being made of a body known as a petty jury to decide all matters of fact. This jury consists of twelve men specially summoned and sworn for the purpose. Growing out of the fact that these men are untrained in the law and are not accustomed to weigh evidence, there has developed an elaborate set of rules governing the character of evidence or testimony of witnesses that may be given to the jury and the manner in which it shall be presented. These rules are known as the laws of evidence and are exceedingly technical. A no small part of the work of judges in the trial of cases coming before them consists in ruling on what evidence shall be given and the manner in which it shall be given. In European coun- 
tries a much more limited use is made of juries, and where used they have quite a different character.

As in the case of the grand jury, a very serious question is here presented as to whether an institution such as the petty jury is in all respects satisfactory under modern conditions; and whether, if retained, the rules governing its operations should not be modified. Especially is this so in respect to the use of a jury in the trial of civil actions. In criminal cases the belief is general that the protection afforded to the accused by the requirement that his guilt shall be established by the unanimous verdict of twelve men is a very valuable safeguard of private rights and liberties. In civil actions where the contest is between individuals in respect to their relative rights and obligations, the use of a jury gives a great advantage to the defendant, since the plaintiff, in order to prevail, must receive the unanimous vote of the twelve men composing the jury, while the defendant need receive only one vote in order to prevent the action going against him. The fact that the large class of cases falling within the jurisdiction of the equity courts are tried without a jury would seem to demonstrate that the use of a jury is not essential in the trial of any civil case.

The foregoing represent only a few of the many questions that are involved in the problem of determining the procedure to be followed by courts in performing their duties. They must be taken as merely suggestive of the character of this problem. Limitations of space permit only the adding of one or two further observations of a general character. The first of these is that the system of judicial procedure that obtains under the American government is almost wholly a matter of historical inheritance. There is scarcely a feature of it that can not be traced back to its 
origin in early English practice. The system as a whole thus developed under conditions far different from those now obtaining. It is intensely formalistic, technical and complicated. In its practical workings it is expensive, results in great delay, and too often is productive of failure to do justice. A no inconsiderable number of cases are decided on matters of technical procedure rather than on their real merits. The time would, therefore, seem to be ripe when this whole system should be subjected to critical study with a view to making it conform more largely to modern conditions and to putting it upon a more economical and efficient basis.

The Problem of an Independent Judiciary.- In the foregoing statement of the problems involved in the organization of the judicial branch of a government we have refrained from making more than incidental mention of one factor, notwithstanding its supreme importance, since it is of so special a character and so vital that special consideration should be given to it. Reference is made to the imperative requirement that the judiciary shall be so organized that it will have complete independence in performing its duties. But this is meant, not merely that courts in adjudicating disputes shall be free from all social, political or other private influences, but that they shall be free from all dictation or control on the part of the other branches or officers of the government. Courts have the function of adjudicating, not merely private disputes, but those arising between individuals and the government, and, if need be; between different branches of the government itself.

In our study of the different types of government we have seen that the greatest advance ever made in the political field consisted in the establishment of the principles that governments should be ones of law, instead of authority, and that 
there are certain fields of individual action into which governments should not enter. If these two great principles are to be maintained; if assurance is to be had that government officers shall not act arbitrarily but that all their acts shall be in strict accordance with law, and that all individuals shall be protected in the enjoyment of the fundamental rights and liberties guaranteed by the constitution, the duty must be placed somewhere for taking the action that will ensure that these conditions are lived up to. It is upon the courts of the land that this duty falls. Manifestly if they are to perform this duty they must be so constituted that they can, not only act fearless of consequences, but exercise the power required in order to secure compliance with their determinations.

It might seem at first that this problem of securing a due compliance with law by officers of the government and the guarantee of individual rights as against the government would arise only in the case of governments of an autocratic character; that it would not arise in the case of a Popular Government where the final control of political affairs was in the hands of the people themselves. This, however, is not so. Popular Government, as has been pointed out, is necessarily government by a majority. The danger is thus always present that a majority of the people at any time may use its powers in an arbitrary manner to oppress the minority. When one considers the extent to which the people of a country, even with a comparatively homogeneous population, are divided into classes, separated by race, color, territorial and economic interests, religious beliefs, and other factors, it can be seen how real this danger is. It has been truly said that no tyranny is so great as that of a majority. One of the great problems confronting a people in establishing a Popular Government is thus 
that of providing means by which this danger may be avoided. Experience has shown that this can be done in but one way; that, namely, by entrusting to the courts the duty of seeing that no branch of government, nor all the branches combined, shall take. any action contrary to law or in violation of the rights guaranteed to individuals.

The result of doing this is to give to the judicial branch of government a status quite distinct from that of the other branches. In the first place, it occupies the anomalous position of being at once a branch of government and yet standing outside of, or at least independent of, the government in order that it may control such government. Secondly, courts are in the equally anomalous position of being agents of the people and yet not representative of the people in the same way as the other branches, since their duty is not that of carrying out the will of the people as represented by a majority of such people, but, on the contrary, of protecting the minority, no matter how small, whenever their rights are threatened or interfered with by such majority. As stated by Mr. Rome G. Brown in an exceedingly able paper, ${ }^{1}$ " one of the chief functions of our courts is to stand between the legislature, although that body may for the time represent the majority of the people, and the individual or individuals who may for the time comprise the minority, and to prevent an infringement by the majority, through the legislature representing them temporarily, of the rights guaranteed to the individual or it may be an entire minority."

No one has described this peculiar status of the judiciary, and expressed its special function of protecting the minority, better than former President William H. Taft. In

1 Address on Recall of Judges before the Minnesota State Bar Association, July I9, IgII. 
his message to Congress, vetoing the resolution providing for the admission of the Territories of Arizona and New Mexico as States in I9I I, due to their constitutions containing clauses which, in his opinion, failed adequately to protect the independence of judges, he said:

The executive and legislative branches are representative of the majority of the people who elected them in guiding the course of the government within the limits of the constitution. They must act for the whole people, of course; but they may properly follow and usually ought to follow the views of the majority which elected them in respect to the governmental policy best adapted to secure the welfare of the whole people. But the judicial branch of the government is not representative of a majority of the people in any such sense, even if the mode of selecting judges is by popular election. . . They are not popular representatives.

Again in an address on the "Judiciary and Progress," delivered at Toledo, Ohio, on March 8, I912, he said:

But the judiciary are not representative in any such sense, whether appointed or elected. The moment they assume their duties they must enforce the law as they find it. They must not only interpret and enforce valid enactments of the legislature according to its intention, but when the legislature in its enactments has transgressed the limitations set upon its power in the constitution the judicial branch of the government must enforce the fundamental and higher law by annulling and declaring invalid the offending legislative enactment. Then the judges are to decide between individuals on principles of right and justice. The great body of the law is unwritten, determined by precedent, and founded on eternal principles of right and morality. This the courts have to declare and enforce. As between the individual and the State, as between the majority and the minority, as between the powerful and the weak, financially, socially, politically, courts must hold an even hand and give judgment without fear or favor. In so doing they are performing a governmental function, but it is a complete misunderstanding of our form of government or any kind of gov- 
ernment that exalts justice and righteousness to assume that judges are bound to follow the will of the majority of an electorate in respect of the issue for their decision. In many cases before the judges that temporary majority is a real party to the controversy to be decided. It may be seeking to deprive an individual or a minority of a right secured by the fundamental law. In such a case, if the judges were mere representatives or agents of the majority to carry out its will, they would lose their judicial character entirely, and the so-called administration of justice would be a farce.

With this understanding of the special function of courts to control the government, to see that no one of the branches exceeds its powers, and that no temporary majority can infringe the rights of the minority, the question is presented of the best means by which assurance may be had that such bodies will have the independence that will permit them fearlessly to discharge it. The best answer to this is found in the provision that judges shall be selected without regard to their political affiliations, that once selected they shall hold office for a long term, for'life, or during good behavior, that they shall not be subject to dismissal by the executive, may be removed only for misconduct as established by a very formal process of impeachment or address on the part of both houses of the legislature, and that their compensation shall not be withheld or diminished during their terms of office. In England these principles were established only as the result of a long struggle between the people and the Crown. Down to and through the period of the Stuart Kings, judges held office at the pleasure of the King. They were dismissed if they thwarted the will of the King, with the result that they were in many cases but the servile agents of the King. Upon the revolution of 1688 one of the great reforms insisted upon was that judges should hold office during good behavior. This 
was resisted by the King, but was finally secured by the Act of Settlement. Later, provision was made that their salaries should not be reduced during their term of office and that they should only be removable upon conviction for some serious offense or upon an address, that is, petition, on the part of both houses.

The great importance of giving independence to the judiciary was fully appreciated by the framers of our constitution. In providing for the organization of the judicial branch, the provision was thus made that the judges of the Supreme Court should be appointed by the President and that all federal judges, no matter how selected, " shall hold their office during good behavior and shall at stated times receive for their services a compensation which shall not be diminished during their continuance in office." It results from this that federal judges may be removed from office only upon conviction for a high crime or misdemeanor as established through the process of impeachment. Though, under the constitution, federal judges, other than those of the Supreme Court, may be otherwise selected, if the law so provides, provision in all cases has been made for the appointment of judges by the President. This method of selection has been adopted for two reasons; one, that it is believed that more competent judges will be secured in this way; and, two, that by so doing the selection of judges is removed from the field of partisan politics.

It is to be. regretted that this policy has not been followed by the individual states in providing for their judicial systems. In most of the states judges are elected by the people, and in many cases the term of office is short. In all cases, however, provision has been made against the arbitrary dismissal of judges by the executive. The opinion of students of our government is almost unanimous 


\section{THE GOVERNMENT OF MODERN STATES}

that the federal system is superior to that of the states and that it is largely due to this difference that the federal judiciary has proven to be far superior to that of the states. Efforts are consequently being constantly made in the states to have the federal system adopted. 


\section{CHAPTER XVI}

\section{THE ADMINISTRATIVE BRANCH}

The last of the grand divisions into which government may be divided is that known as the administrative. This is the branch which has as its function the actual putting into execution of the policies adopted by the government. In studying this branch it is desirable again to describe its precise position in the general scheme of government and certain characteristics of its work, even though this may involve a measure of repetition of what has already been given.

Non-Political Character of the Administrative Branch. - In our consideration of the distribution of governmental powers functionally, we have pointed out the essential difference between the executive and the administrative functions. The former is distinctly of a political character. It involves the making of far-reaching decisions in respect to governmental policies. In respect to the actual conduct of governmental affairs it has to do with seeing that policies that are adopted, or lines of action that are decided upon, are properly carried into effect rather than in undertaking the work proper of putting these policies and programs into execution. Or, to use the expression employed in our constitution, it consists in seeing that the laws are duly enforced, not in doing the work involved in enforcing such laws. The latter function, the administrative, on the other hand, strictly speaking involves the making of no decisions of a political character. Its participation in the making of 
such decisions is, or should be, merely that of furnishing to the policy-determining organs of government, the legislative and the executive, the facts which should be taken into account by those organs in reaching their decisions. Apart from this the duties of the administrative branch should consist solely in the execution of orders. In doing so political considerations should have no weight other than that the work ordered should be done in such a manner as to put into execution the policies decided upon.

The distinction here made is important in any form of government. It is especially so in a Popular Government where the people are divided into political parties. No greater abuse in government can take place than that of the administrative branch of government using its powers to promote the interests of any particular political party. Unfortunately, this is a principle which is only too often violated. In our own government it has taken the form of treating many purely administrative positions as party spoils to be filled by persons belonging to the party in power, rather than by those selected solely with a view to their special competence; of expending public moneys for public buildings and other works in response to political demands, rather than real needs; and of administrative officers using their positions to advance the interests of their parties. In times past these abuses were much more in evidence than they are at the present time. Much, however, still remains to be done if these evils are to be completely eliminated.

Distinction Between the Function of Direction, Supervision and Control and That of Execution.- If the work involved in the administration of any service or enterprise is subjected to analysis certain important distinctions appear. The first of these is that between the function of direction, supervision and control, on the one hand, and 
execution on the other. In small undertakings, and especially in ones managed directly by the owner of the enterprise, this distinction may not be of significance. In those cases it is feasible for the same person to exercise both functions, and the fact that the second must be performed in subordination to the first is lost sight of. In all large undertakings, and especially in those such as modern governments, comprehending the prosecution of varied lines of activities, the distinction is one of prime importance. Not only are the two functions to be clearly distinguished but, for the most part, their performance must be vested in separate hands. One organ should have responsibility for directing what work shall be undertaken, for determining the general conditions under which the work shall be done, for providing the funds required for its execution, and for currently exercising that general supervision and control that is required in order that assurance may be had that orders given are properly and efficiently carried out. Other organs should have the responsibility for the actual performance of the work so determined upon.

This distinction is one which, as we have pointed out in our consideration of the legislative branch of government, is clearly made in the government of the United States. As is there shown, the whole power of direction, supervision and control of administrative affairs legally is vested in Congress. The executive departments and other administrative services are mere agencies of that body for the carrying out of its orders. A thorough comprehension of this fact is the first essential in understanding the true character of the administrative branch of our government. This is all the more necessary since in popular estimation, and, to a considerable extent, in appearance, the President seems to occupy this position. There can be no question regarding 
the great powers of direction, supervision and control of the President over the administrative work of the government. These powers, however, are primarily exercised by him but as an agent of Congress, which as a matter of expediency has conferred them upon him. They are, moreover, greatly strengthened by three facts: (I), that the President, as chief executive, has the duty of seeing that all laws are duly enforced; (2), that to a large extent the power of appointing and removing administrative officers is vested in his hands; and, (3), that the position is now generally held by all parties, administrative officers, the public and Congress itself, that the President should in a way be looked upon as the head of the administration. In taking this position, however, sight should never be lost of the fact that the real seat of administrative authority is in Congress and not in the President. The distinction is that between the position and powers of a board of directors and a president in an ordinary corporation.

Congress as a Board of Directors.- Having drawn this distinction between the function of direction, supervision and control and that of execution, it is evident that the problem is presented in the case of each of devising the means through which it may be effectively performed. In respect to the first but a few words will be required to make known the character of this problem.

The work of direction is performed by the process of legislation. The problem of organization and procedure in its performance is thus practically the same as that for the performance of the function of legislation properly speaking, and need not therefore be specially considered here. Mention, however, should be made of the fact that Congress, in common with most legislative bodies, has devised a system of committee organization and procedure with a view al- 
most solely to the exercise of its law-making function. (Only to a comparatively slight extent has it organized and formulated rules of procedure with special reference to the performance of its function as a board of directors. The result is that its organization and methods of procedure are not well adapted for the performance of this function. Especially is its whole committee system and procedure governing the consideration of appropriation bills which constitute the main means of giving administrative directions defective. Involved in this question is the great problem of budgetary procedure. This, however, is so technical a problem that it is impossible for us to undertake its consideration. ${ }^{1}$

When a board of directors has given orders as to what shall be done it has discharged but one phase of its responsibilities. It is incumbent upon it to provide means by which it may insure that its orders are in fact carried out ; in other words, means by which it may effectively exercise its function of supervision and control. The means available for this purpose consist in the requirement that its executing agents, the administrative services, shall keep accurate records of all their acts and financial operations; that at stated intervals, or whenever called upon, they shall submit to it detailed reports setting forth their transactions in such form that their character and purport may be readily understood; that it shall provide itself with an agency by which these accounts and reports may be critically examined; and, finally, that it shall make provision for itself considering the facts so brought to its attention, to the end that it may

1 This special phase of administration has been handled at length by the author in his recent work "The Problem of a National Budget:" Studies in Administration: Institute for Government Research. D. Appleton \& Co., 1918. 
take such corrective action as the facts shown may warrant. All modern governments meet these requirements to a greater or less extent. Administrative departments are required to keep records and accounts and to submit reports. These accounts are subject to a critical examination made by an officer known as Auditor or Comptroller. And the facts thus rendered available are given consideration by the legislature. In few cases, however, have the technical problems involved in establishing a proper system of accounts and reports, and in providing for their audit, been satisfactorily worked out. Especially is this true of the United States Government, and most of our state and municipal governments. Nor have governments very generally evolved satisfactory means for considering such facts as are brought out by these documents. The result is that legislative bodies very generally fail to exercise that supervision and control over the conduct of administrative affairs that is essential if efficient and economical administration is to be had. It is desired to emphasize this point, since responsibility for bad administration is too often placed upon the executing agencies. That a large measure of responsibility falls upon them is undoubted. On the other hand, it is of great importance to recognize that primarily the responsibility rests upon the directing authority which has failed to perform properly its function of giving the direction in the proper form, of seeing that records and reports are kept and made in proper form, and of exercising in a proper way its function of supervision and control.

Organization and Administration of the Administrative Services.- Turning now to a consideration of the problem involved in the organization, and the determination of the methods of operation of administrative services, it will be found that these problems are essentially those that 
are presented in providing for the conduct of any large enterprise. They may be classified under the following four heads :

I. Problems of organization.

2. Problems of personnel.

3. Problems of matériel.

4. Problems of business practice and procedure.

In other words, persons responsible for the determination of the manner in which the work of the administrative branch of the government shall be performed have to do the following four things: First, they must determine the structural character or organization of the service or services by means of which the work of administration is to be performed. Secondly, they must make provision for the manning of this organization with a personnel and the determination of the conditions under which such personnel will give their services. Thirdly, they must provide for the material equipment required by this organization for the performance of its duties or fix the conditions under which such matériel will be acquired. And, finally, decision has to be reached regarding the methods that will be employed in operating the services. These are all, it will be seen, matters purely of business administration. Anything like a full examination of them would carry us far beyond the scope of the present work. A few words regarding each to make their general purport clear will, however, be in place.

Problems of Organization.- Problems of organization may be divided into two classes which, for want of better terms, may be designated technical and general. Viewed individually and technically, each administrative service must be specially organized for the performance of the particular duties that it is to perform. In this sense there may be said to be as many problems of organization as there are 
classes of work to be done. Into this class of organization problems it is, of course, impracticable for us to enter. If we disregard these special and technical problems, and consider the problems of organization from the general standpoint, it will be found, however, that there are certain features that are more or less common to all services of any considerable importance, or which are general in the sense that they have to do with the relations of services with each other, rather than with them individually. It is with these general problems alone that we can here concern ourselves.

Among these first in importance is that of working out a systematic scheme of organization units for the handling of the administrative work to be done. This means reaching a decision regarding the specific services that shall be created, the manner in which these services shall be grouped, and the nature of the relations that shall obtain among them. In practice this problem has been met by governments in two ways. The first consists in the establishment of as many independent services, in the form of bureaus, boards, commissions, etc., as there are classes of activities to be performed, each of these services having relations directly with the legislature creating it. This is the system which has generally been adopted by our states. The second consists in the establishment of a system where the attempt is made to group these several services according to their character into departments. This system which is known as an integrated system of administration is the one which has been adopted by our national government.

Of the relative merits of these two systems there can be no question. The second is far superior. It makes provision for an effective overhead administration and control, permits of a logical distribution of duties among services, lessens the danger of overlapping of jurisdictions and dupli- 
cation of organization and activities; facilitates the establishment of cooperative relations between services and renders easier the standardization of methods.

At the present time few reforms of government in the United States are more urgent than that of the reorganization of the administrative services of our state governments, so as to put them upon the integrated or departmental basis. Fortunately, the need for this reform is being appreciated and a number of the states, of which Illinois is a notable example, have entered upon this work. In the case of the national government also much remains to be done. Though it has adopted the right system, it has not in all cases worked out the details in a satisfactory manner. This has arisen from the fact that the system was not established all at once, but has come into existence by: a process of gradual growth. The time has consequently come when the whole administrative branch of the national government should be subjected to a detailed examination with a view to determining what new departments, if any, should be created, what new grouping of services should be made departmentally, what changes should be made in the distribution of duties among the several services, and what steps should be taken better to standardize their internal organization and methods of procedure. Especially has this necessity become urgent since the creation of the large number of special agencies that have been established for meeting the war needs of the government. A thorough reorganization of its administrative branch thus constitutes one of the important tasks of reconstruction confronting our government upon the conclusion of the war.

Another general problem of administration is that of creating a central service to exercise immediate supervision and control over the organization, activities, and methods of 
work 'of the several services. We have seen that the function of general direction, supervision and control is, under our system of government, vested in the legislature. It is impossible, however, for that body to exercise this function except in the most general manner. The members of those bodies have neither the technical qualifications nor the time to exercise the current, day-to-day direction, supervision and control that must be had if efficiency in operation is to be secured. This can be done only by officials giving their whole attention to the work, and in immediate touch with operations. The duties of such a central administrative service consist in formulating and prescribing systems of accounts and reports that will be uniform for all the services; in standardizing methods; in acting as the body to receive, compile and present to the legislature the estimates of appropriations needed; in settling disputes between services in respect to their respective jurisdictions; and generally in attending to those matters which concern all the services rather than the services individually.

Special mention is made of this problem, since so little has been done in either our national or state governments to meet it. In the case of the former, the President, as we have seen, has, in effect, been given the duties of administrator-in-chief, and the whole tendency in the governments of the states is to erect the Governor into a similar officer. In no case, however, has adequate provision been made for a central bureau of administration, through which the President or Governor may properly perform his duties as chief administrator. The provision of such a service thus constitutes one of the essential steps in putting the administrative branches of our national and state governments upon an efficient basis. In England this requirement has been admirably met in the Treasury Department. That depart- 
ment, notwithstanding its name, is not a service for the management of the financial services properly speaking. It is purely a service of general overhead administration for the performance of the duties which we have stated belong to such a service. ${ }^{1}$

Turning now to a consideration of the problems presented in the organization of individual services, a first requirement of efficiency is a recognition of the distinction between what is known as: (I) General Administration, (2) Staif, and (3) Line. Just as it is necessary that the administrative branch of the government as a whole should have a service of general administration, so each department and each important bureau or other subdivision should have a similar service. If we analyze the work of any service, it will be found to be of two kinds: (I) that having to do with the maintenance and operation of the service as a service; and (2) that having to do with the performance of the work for which the service is created and maintained. The first class of duties consists of such work as the provision, maintenance and care of plant, quarters, and equipment, the recruitment of personnel, the receipt, custody and disbursement of funds, the keeping of accounts and rendition of reports, and purchase and issue of materials and supplies, the handling and filing of correspondence, etc. It is very desirable that this class of duties, which is commonly known as that of general administration, should be carefully segregated and entrusted to a special group of officers under an executive officer whose sole responsibility is that of seeing that these duties are properly performed.

1 For a full account of the functions of this department see, "The System of Financial Administration of Great Britain," by W. F. Willoughby, W. W. Willoughby, and S. M. Lindsay. Studies in Administration, Institution for Government Research. D. Appleton \& Co., 1917. 
In most services of importance, and especially those whose line activities are of a technical character, there also exists the need for a corps of technical advisers. These advisers are collectively known as the staff. Their duties are those of research, critical examination of work programs and methods, and the giving of advice." They do not, or at least should not, have any administrative duties properly speaking. The best example of such a service is that of the General Staff of the War Department. Here, too, it is desirable that this class of work should be carefully segregated and placed under the direction of an officer known as Chief of Staff.

Finally, there is the class of duties consisting of the actual performance of the work for which the service is maintained. The units performing this work constitute what are known as the operating departments and the work itself is of a special or technical character.

We have given this analysis of the work of any large and complex service, not as one that is generally recognized and acted upon in organizing the administrative branch of a government, but as one which should be given consideration in doing that work. In point of fact the distinction is one which finds expression in few governmental systems. It is, therefore, all the more desirable that it should be here considered where the main purpose is to get before the student the problem of government rather than a mere description of governments as they exist.

Problems of Personnel.- Problems of personnel constitute the second of the four groups into which for purposes of study we have divided the problems of public administration. Of these groups it is at once one of the most important, most complex, in the sense of presenting a multitude of phases or considerations, and most needing care- 
ful analysis and study. It includes such problems as those of determining the method of recruiting employees, fixing their compensation, providing means, through efficiency records or otherwise, of passing upon the manner in which they discharge their duties, and of making promosions, classifying employees according to the nature of their work, formulating rules to govern the matter of the discipline and, if need be, discharge of employees, and scores of other like questions. All of these are matters of great importance. No amount of care in determining how a government shall be organized for the performance of its work, the particular practices and procedure that shall be employed by it and the manner in which the funds necessary for its support shall be raised and expended, will give even a measurable approach to efficiency in the actual administration of public affairs unless a technically competent personnel can be secured and retained in the service and a system is devised whereby this personnel may be effectively directed and controlled.

Into these questions it is impossible for us here to enter, important though they are and much as they need attention in this country. There are, however, certain general phases of the problem which concern the very foundation of a government personnel system which should receive attention.

If we examine the personnel systems of the leading governments of the world, it will be found that they are fundamentally different according to the principles on which they are based. At one end of the scale stands the purely bureaucratic type of Prussia. Much misapprehension exists in regard to the true character of this system due to the two senses in which the term "bureaucratic" may be employed in describing a system of organization and personnel administration. In its larger sense this term is used to describe any personnel system where the employees are classified in a 
system of administration composed of a hierarchy of sections, divisions, bureaus, departments and the like. Used in this sense there can be nothing to justify the prejudices which exist in the United States against what is known as a bureaucracy. Such a system is in fact the one that must be established in the case of any large undertaking if efficiency in operation is to be secured.

The term bureaucracy can be, and is, however, used in a much more restricted and special sense as descriptive of a body of public servants organized in a hierarchical system which stands outside of the sphere of effective public control. It is in this sense that it is employed in designating the Prussian civil service system. The prime characteristic of this system is that it represents a body of public servants owing their positions directly to the authority of the King. They are in the fullest possible acceptance of the term but the servants of the King, the agents through whom he exercises his autocratic powers as head of the administration. Due to this fact the King has been able to organize the civil branch of the government upon a basis substantially similar to the military branch of the government. It constitutes as distinct a career as those of the military and naval establishments. Special provisions exist for the education and training of those contemplating adopting its several branches as careers. After entrance, members of it advance in a regular gradation of positions and in conformity with general regulations. Their tenure of office is as fixed and secure as in the case of the military and naval services. Practically the same care is given to the determination of the titles employed in designating officers of different grades and to the social and other advantages and prerogatives attaching to such offices as in those services. The result of these provisions is to bring into existence a body of public servants 
who constitute a distinct class in the community in the same way as do the military and naval forces. This condition, it should be stated, obtains not only in respect to the national government, but to a scarcely less degree in the case of the municipal and other local governments of the kingdom. Even the office of Burgermeister or chief executive of cities is a profession and persons holding this office pass freely from one city to another.

There can be no question of the advantages which such a system offers from the standpoint of efficiency. Under it conduct need be dictated only by considerations of administrative efficiency. There is every incentive to secure efficient employees and to enforce efficiency in the performance of duties.

We have mentioned this point with special care since there exists such a widespread misconception in respect to the secret of the undoubted efficiency of the Prussian civil service administration. Commonly it is ascribed to the peculiar efficiency and capacity for organization of the German. In point of fact, it is doubtful whether the individual German has an ability or a capacity for organization equal or superior to that of the American. The real explanation of the efficiency of the German system is to be found in the characteristic which we have mentioned; namely, the autocratic basis upon which it rests in respect to the status and powers of the personnel and its independence of outside pressure and control.

Notwithstanding the advantages of this system examination will show that there are inherent in it certain disadvantages or dangers which go far towards justifying the deep-seated distrust that Americans have of it. The fact that, under it, government employees are servants of the Crown rather than of the people tends to make them, not 
only unresponsive to public demands, but to assume a superior or overbearing attitude to the public. That this feature is very much in evidence in the Prussian system any one who has had contact with it can testify. All of the evils of militarism, as they concern the relations between the military establishment and the general population, are latent if not positively expressed, in the case of a bureaucracy such as we have been describing.

What is of far greater importance, however, is the power which this system gives to a ruler to control both the general social and political life of the people. In Prussia this power has been exercised by the King in a most ruthless manner to control elections and to secure the attainment of his political aims. In a very direct way the system has been used as an instrument to restrict the liberties of the people.

With a true understanding of the nature of a bureaucracy it must be apparent that the dangers which the American people apprehend as residing in this type of organization are under American conditions wholly non-existent. A bureaucracy of the Prussian type can only exist in a government resting upon the principle of autocracy.) (In America all political powers are derived from the people and final authority over all political agents is in their hands.) The objections to a bureaucracy which we have named, in a word, are not due to the existence of a permanent civil service highly organized in a hierarchical system, but to the location of the supreme power over this system. There is thus no reason why the American people, if they are so minded, may not secure a civil service possessing most, if not all, of the advantages of the Prussian bureaucracy with none of its dangers and disadvantages. We may go further than this and say that, until we are prepared to bring into existence 
a bureaucracy in the sense of a well-organized hierarchy of permanent positions, it will be impossible to secure a thoroughly efficient personnel system.

In England we have another type which may be characterized as the aristocratic in contrast with the autocratic type of Prussia. A distinguishing feature of this system is the sharp distinction which is drawn between different grades of personnel, and the difficulty which exists in passing from one grade to another. There is first the class of permanent under secretaries and assistant secretaries. No attempt is made to apply the competitive principle in recruiting this class. Its members hold office by appointment based upon the personal judgment of the appointing officers as to their capacities; and selections may be made from persons already in the government service or who have never held public office. The theory is that the qualifications desired of this class are of so special a character, involve to so large an extent the matter of personal equation, and the relations between them and their appointing officers are of so personal a nature, that the latter should have broad discretionary powers in making their selections. Next there is the class of superior administrative officers to whom is given the designation of first class clerks. This class includes all those who, subject to the authority of their superior officers, the heads of the departments, the under secretaries and assistant secretaries, occupy the more important positions and constitute the great bulk of what may be called the directing personnel. This class is almost wholly recruited by means of special competitive examination, the conditions and character of which are so fixed that practically only graduates of the universities of Oxford and Cambridge can hope to compete with success. Only in exceptional cases are these positions filled by promotion of employees in the lower ranks. 
Finally, there are a number of classes of subordinate personnel, the ranks of which are recruited by special competitive examinations, and in less degree by promotion of persons within the services.

This system is based upon substantially the same principles and considerations that obtain in the military and naval services. Substantially the same clear distinction is made between the directing personnel, or officer class, and the general line of employees, that is made in the latter services between commissioned officers and enlisted men. And the same difficulty exists in passing from one class to another that obtains in those services. The theory is, though it is not always openly avowed, that the directing personnel should, not only have qualifications which can only be secured by special training such as is given in higher universities, but that they should be drawn from the upper classes of the population. This system, which is often described as one of water-tight compartments, is, it will be observed, congenial to the aristocratic character of the social system of England. Primarily its adoption is due to this fact, rather than to the deliberate opinion on the part of those entrusted with the conduct of public affairs of its intrinsic merit. The arguments that are brought forward in favor of it represent thus but the effort to justify a decision that has been made upon other grounds.

The system of the United States presents still a third type of civil service organization. In thus characterizing the American civil service as a distinct type, reference is not made to one of its most characteristic features, the extent to which public offices are treated as political spoils, but rather to the character that has been given to the system where the effort has been made to take it outside of the domain of politics and put it upon a merit basis. A distin- 
guishing feature of both the German and English systems is that they are based upon the principle of recruiting their personnel from among young people just leaving school and who have deliberately selected the government service as their life occupation. Thus, in the English system candidates for first-class clerkships must be between the ages of 22 and 24 years, those for second division clerkships from I7 to 20 years, and those for the position of boy clerks from I 5 to I7 years. It results from this that the whole system of entrance examinations is framed on the basis of determining merely the general qualifications of candidates. They will receive their technical training for the performance of particular tasks after they are in the service. All these features, it will be observed, are consonant with the principle of making the public service a permanent career for its personnel.

In the United States the whole principle upon which the personnel system is based is radically different. The theory seems to be that the government service is not one to be deliberately adopted by young persons as their life vocation. The age requirements are such that persons well along in life may enter; and, in fact, to a large extent, persons entering the government service have previously been employed in other capacities. Entrance examinations, instead of being of a general character, are highly specialized. The effort is made to secure persons already possessing the particular technical training fitting them to perform the work called for by the particular positions to be filled.

This is not the place to consider the relative merits of these systems. All that it is sought to do here is to make evident that a government should carefully determine the general features of the personnel system that it desires to possess before seeking to work out any of its details, since 
as has been shown, the system adopted will control many features, among the most important of which is that of the requirements that will be demanded of candidates for entrance to the service.

Problems of Matériel.- Under the heading of Problems of Matériel are grouped all those questions having to do with the securing and handling of the physical plants, equipment, materials and supplies needed by administrative services for the performance of their work. They are questions which confront all services, though in some they are much more important than in others. In a small undertaking, and especially in one under the direct management of the owner, the procurement of the materials, equipment and supplies needed for the conduct of the undertaking, though a matter of prime importance and, indeed, one where the efficiency with which it is performed often determines the success of the enterprise, is nevertheless a matter giving rise to no difficult questions of organization and procedure. In such undertakings such work is usually handled directly by the owner or general manager. All that it requires is the exercise of sound judgment in respect to requirements, and due care in meeting these requirements, which latter can usually be done by direct purchase in the open market.

Immediately upon an undertaking assuming any magnitude the whole nature of the problem changes. Especially is this true when the undertaking is of a character involving the performance of a variety of activities or the production of a wide range of products. And still more is it true of a government which, in addition to engaging in numerous different lines of work, has to carry on its operations under special legal restrictions having for their purpose to ensure fidelity on the part of all officers and employees.

One of the first consequences of this changed condition 
of affairs is the necessity for definitely segregating the function of procurement of articles required for the due conduct of the affairs of services from that of their utilization, and of vesting these two functions in the hands of separate offices or units of organization. This is necessary for two reasons: First, it is desirable that those charged with operations proper shall, as far as possible, be relieved of all collateral obligations and responsibilities and be placed in a position where they can devote their whole attention and energies to the work in hand. Secondly, the work of procuring the articles needed becomes one requiring such a variety of highly specialized knowledge and experience that it can be effectively performed only by officers devoting themselves exclusively to the work. The best example of the need for and the actual segregation of such duties is furnished by our War Department. Here the line, or army proper, does not concern itself with the securing of ordnance, ammunition, trucks, uniforms, and the thousand and one other articles required by it for the conduct of its operations in the field. All this work is attended to by the so-called great supply services, the Quartermaster's Department, the Ordnance Department, etc.

The procurement of supplies constitutes but one phase of the supply problem. Others consist in definitely formulating requirement needs in the form of specifications, in providing for the receipt, custody and issue of supplies, in subjecting them to examination for the purpose of determining whether they are of the quantity and quality called for. In a government a question of great importance is whether each service shall have its own supply service or whether the work of supply shall be handled by central purchasing departments. At the present time the tendency is strongly in the direction of the latter alternative. 
Into questions of administrative details such as these we cannot of course enter. We shall have to content ourselves with doing little more than making known the special character and importance of this aspect of organizing the administrative branch of a government as a going concern. ${ }^{1}$

Problems of Business Practice and Procedure.- Having made provision for the organization of the administrative branch of the government and the furnishing to it of the personnel and physical equipment and supplies needed by it for the performance of its work, there then remains the duty of formulating the rules of procedure under which the work will actually be carried on. By this is meant not the adoption of the technical methods that will be employed by the operating units, but the general business procedure that will be employed that the work as a whole may efficiently go on. Among the matters coming in this field are such as the handling and filing of correspondence and other documents, the keeping of property records, the provision of means by which those in authority may keep themselves currently informed regarding work projected, under way, or accomplished, and be in a position effectively to exercise their function of control, and, above all, the keeping of accounts that will accurately record all financial transactions, and the preparation and rendition of reports that will render the facts so recorded readily available.

This last constitutes one of the most important problems of administration that confront any government. It involves the whole great question of how revenue shall be collected, how disbursed, accounted for, audited and re-

1 For a consideration in detail of the problems of purchasing on the part of governments, see "Principles of Government Purchasing," by A. G. Thomas. Studies in Administration, Institute for Government Research. D. Appleton \& Co., I9I8. 
ported. Financial accounts constitute far the most effective means of judging regarding needs and accomplishments. Unless accurate records are kept of all revenues and expenditures and full and detailed reports made of them it is impossible either for administrators or those responsible for formulating governmental policies properly to perform their work. In the past the accounts of our governments have in general been so kept as to provide for a due accounting for all moneys secured and disbursed. They have not been kept, however, in such a form as to furnish the information required for intelligent legislative and administrative control. Improvement in this respect is being made but much yet remains to be done. 


\section{CHAPTER XVII}

THE RÔLE OF POLITICAL PARTIES IN MODERN GOVERNMENTS

In our examination of the electoral branch of government we have purposely refrained from giving consideration to the most striking feature of electoral activities as actually manifested, namely, that everywhere the electorate tends to split itself up into groups of electors known as political parties to the end that unity of action may be had by those who think alike in respect to who shall be elected as their representatives and what shall be the policies that they desire such representatives to put into execution. There is no more difficult, and few more important, problems in the whole domain of political science than that presented by this phenomenon of political parties. It has fundamentally altered the whole problem of government. It is, therefore, desirable that it should receive special attention.

Political Parties a Recent Phenomenon.- In studying this phenomenon of political parties the first fact to strike the inquirer is that, in their modern form at least, they are of comparatively recent development. They can hardly be said to go back to the nineteenth century. Their rise in fact coincides with the rise and development of Popular Government.

Political Parties First Viewed as an Evil.-A second important fact that at once appears is that at the start there was no appreciation of the inevitableness of the rise of these organizations, much less of the dominant part that they were to play in the political life of all peoples having a Popular 
Government. More than this their rise has in all cases been looked upon as an evil and as constituting a serious danger to the state. "No one in the eighteenth century," writes Mr. A. Lawrence Lowell, in his exceedingly able work on "The Government of England," 1 " foresaw party government as it exists today, enfolding the whole surface of public life in its constant ebb and flow. An occasional man like Burke could speak of party without condemnation; but with most writers on political philosophy parties were commonly called factions, and were assumed to be subversive of good order and the public welfare... To them the idea of a party opposed to the government was associated with a band of selfish intriguers, or a movement that endangered the public peace and the security of political institutions. ... They (political parties) were never far removed from violence. When the opposition of those days did not actually lead to bloodshed, it was perilously near to plots and insurrection; and the fallen minister, who was driven from power by popular feeling or the hostility of Parliament, passed under the shadow at least of the scaffold."

This is practically the conception that the framers of our constitution had of these bodies. One has but to read the constitution to appreciate that its framers had no idea that political parties would become one of the essential features of our political system. This arose from the belief on their part that they were creating a government of a purely representative character, one where the people would attempt to do nothing in the way of directly formulating policies or determining what would be done by their government, but would content themselves with selecting representatives who would act for them in all capacities. Their ideal was that

1 Vol. I, p. 436. 
of the modern large corporation where the stockholders confine their activities to the election of a few chief officers and a board of directors and leave to these officers the whole responsibility for the formulation of policies as well as their execution.

It is hardly necessary to say how completely these early ideas both in England and the United States have failed of realization. Electorates have not been content to occupy this comparatively netitral position. Everywhere they have formed themselves into political groupings for the purpose of effectively making known their wishes, until today such groupings constitute integral parts of the political machinery of most modern nations.

\section{Political Parties Not a Deliberate Creation of Law.-} A third noteworthy fact about these organizations is that, notwithstanding the fact that they now constitute integral parts of the political machinery of the countries in which they have developed, they have in no case been deliberately created as political institutions. One may read the constitutions of all States without finding the slightest, or at best more than the most incidental, reference to such bodies. The same is true in great part of the statutes. Political parties in fact have grown up outside of the law and to a very large extent continue to function at the present time as extralegal institutions. Even where they have developed grave defects in their operations governments have hesitated to step in and attempt their correction by legislation. When one considers the important part that they now play in the actual conduct of governmental affairs, this situation must be deemed to be one that is little short of remarkable. The importance of their rôle is such that it is essential that all students of government should have at least a general idea of the real meaning of this phenomenon, the principles upon 
which political parties are organized in different countries, the true functions of these bodies in governments of different types and the character of the methods employed by them in carrying on their activities.

Distinction Between Political Parties Inside the Government and Outside the Government. - In entering upon a study of political parties a clear understanding should be had regarding the two senses in which this term may be employed. In all nations where the rule is not absolutely autocratic and dictatorial, differences of opinion will exist in respect to matters of public policy and contests will take place between individuals to hold office and to exercise power. Where any scope is given to such differences and conflict of ambitions, the persons exercising political authority or influence will divide themselves into groups in order better to further their ends. Many times this division into groups, though nominally based upon differences of opinion regarding public policies, is, in reality, little more than a union of persons seeking, by this means, to secure public office for themselves and their friends, or to exercise for selfish ends the controlling influence over the direction of public affairs. Unions of this character have, in the past, usually been designated as political parties and that term is still employed to describe such groupings.

Political parties of this character the world has had almost from the beginning of organized government. Within recent years, that is, since the opening of the nineteenth century, there has, however, arisen a new phenomenon, that of the division of the general population into vast groupings having for their purpose to make prevail their ideas regarding the character of the government that the country shall have, the persons who shall hold the offices of chief importance and the general policies that shall be pursued by those 
so exercising authority. To these groupings the same term, political parties, is given.

It needs but a moment's reflection to perceive that these two phenomena, though similarly designated, are wholly different in character and give rise to wholly different considerations. The first represents a grouping of persons inside the government, of those actually holding office or exercising a voice in the direction of public affairs; the second constitutes a grouping of persons outside the government, of those holding no office and not participating in any way in the direct management of public affairs, but yet seeking to determine how and by whom these affairs shall be conducted. Under the first phenomenon we have a union of the determining and the executing functions in the same hands. Under the second we have a tendency to dissociate the two, and to vest the one, the determining function, in the hands of one organ, political parties, and the other, the executing function, in another, the government proper. In the first we have a concentration of authority and responsibility; in the second a diffusion of these obligations.

It needs but a statement of this distinction to make evident that in the rise of the second phenomenon we have to deal with an element which has changed radically the whole problem of government. It has raised questions never before presented; ones, moreover, to which no nation has as yet found a final answer. We have but to study the operation of political parties of this latter description in any country, even in those in which bodies of this character have firmly established themselves as integral parts of their political systems, to perceive that no final determination has been reached regarding the true place or function of these bodies in such systems, the manner in which they should be organized and operated, the relation that they should occupy 
towards the government proper, etc. In all but possibly one or two countries hardly the first beginning has been made towards a satisfactory adjustment of these questions.

In no two countries have political parties assumed the same form or taken to themselves precisely the same functions. It is our intention in the pages that follow to describe briefly the systems of political parties in the United States and certain of the leading countries of Europe as the best means of making known the character of the problems to which these organizations give rise. Before doing so it is necessary, however, to point out the two principles upon which representation in a Popular Government may take place, since without a knowledge of the difference between the two it is impossible to understand the different systems of political parties that have been developed in the countries studied.

\section{Two Principles of Representation: The Representa-} tive and the Agency.- In applying the principle of representation to governments two methods are open. The first consists in the people giving the officers or organs having the duty of representing them what may be termed a full power of attorney so to conduct the affairs of government as to them seems wise. It is the principle of a large body of persons selecting their wise men to act for them. When this is done such officers and organs are representative in the truest sense of the term. They are not agents in the sense that it is their duty to take orders from, or to act as officers to execute orders given by the people. On the contrary, bodies of this character rest upon the principle that the people, as a whole, are not competent to reach sound decisions regarding matters of state policy and legislation; or, that, granting the capacity of the people taken individually, it is an impossibility for so numerous an assembly of units to 
reach any general or specific opinions that will represent the collective will of the people and be generally acceptable. This principle thus rests upon the basis that while the people should have a voice in the conduct of public affairs this voice can best and most effectively be exercised by a small body of select and highly qualified specialists rather than by the people themselves. It is of the essence of this principle that such a body of wise men shall act upon their own best judgment. While it is their obligation to keep steadily in mind the interests of the people and to seek to determine what are their wishes, the responsibility for the final decisions made is theirs. A body acting in such a way is a representative assembly of a pure type.

A second principle of representation is that to which, for want of a better term, we may give the designation "Agency." The theory underlying this principle is that the popular assembly is but a means for carrying out the will of the people. It thus acts as an agent and as an agent is under the obligation to carry out such orders as it may receive from its principal, the sovereign people. Under this theory, the people constitute not only the legal but the real seat of authority.

It is hardly necessary for us to point out how overwhelmingly important it is, as affecting the character of the political system resulting, whether the one or the other of these two principles of organizing and operating a popular assembly is followed. In the extent to which one or the other has actually been followed we find the main difference between the systems of political parties as they exist at the present time in the chief countries of the world in which the principle of Popular Government prevails.

The System of Political Parties in England.-We have already seen that in England, no less than in our own coun- 
try, the rise of political parties in the modern sense is of comparatively recent date. They may in fact be said to date from the famous Reform Act of 1832 by which Great Britain inaugurated its movement for the reform of its then corrupt and illogical electoral system. Under the old system many electoral districts had but a small number of voters and these were, in great part, under the domination of a few large landowners or had their votes controlled through government or other influences. Not until the franchise had been broadened so as to include a considerable portion of the adult male population and guarantees had been afforded that this franchise could be freely exercised was there laid the basis for political parties in any modern sense.

For a long time prior to this period England, however, had had Representative Government and what were known as political parties. These parties, however, were of the character which we have described as existing inside the government. This is evidenced by the fact that the first public speech intended to influence the action of voters was that of Lord John Russell in I83 I. As late as I886 Gladstone had to defend himself to the Queen for making speeches outside of his own constituency. The fact is that, not until our own generation did the idea prevail that the people outside of the government should, by the foundation of political parties, seek to exercise a direct and positive influence upon the conduct of government.

Though the fact is now well established that no Ministry can long retain power unless it has the support of a majority of the voters of the nation, this feature that the function of the electorate is to approve or disapprove of policies as formulated and put into practice by the ministry in power, rather than itself to determine or originate political programs, still constitutes the distinguishing feature of the British party 


\section{THE GOVERNMENT OF MODERN STATES}

system. Especially does it mark off that system from the one which prevails in the United States. Under this system, the government resulting is one of public opinion, but this opinion is exerted indirectly, or rather, in an unformulated or non-mandatory way. It controls in the last resort since the members of Parliament and particularly the ministry, are well aware that appeal for support of their policies must constantly be made to the people as vacancies occur in individual constituencies and at least once in five years to the whole body of voters when Parliament is dissolved. Though public policies and legislative programs are thus framed by those in power according to their best judgment, this judgment is controlled by the will of the people as expressed through the public press, petitions, meetings, etc. The important point, however, is that the initiative, the actual formulation of such program, is made by those inside the government and that the positive function of the voters is that of approving the program so made rather than of directing what such program shall be.

Another feature of significance in the English system is that the division of opinion on the part of the voters and the consequent party alignment, takes place almost wholly in respect to public issues. Only to a minor degree is it influenced by a desire to put this or that particular man in office. Actually all that the voters do when casting their ballots is to express their wishes as to whether the program advocated by the ministry in power or the one advocated by the opposition in Parliament shall be followed. The individuals voted for have declared their position in respect to these alternative programs, and it is well understood that they are under the obligation to adhere to such declaration, even though their individual judgments may at times be opposed to particular features of such program or to the 
line of action decided upon by their party in respect to such new issues as may arise.

The most significant consequence of this system is that political parties have not made the attempt to convert themselves into organs of the government. They do not seek to determine who shall hold this or that particular office. They make no effort to control the conduct of governmental affairs except in so far as they may influence it indirectly by giving expression to their opinion through the public press and otherwise. The English have thus made the fundamental decision that their government, while being a Popular Government, shall be a Representative Government and not a Democracy, and that the principle of representation shall be the "Representative" and not the "Agency" principle, as these terms are here used. The English have thus succeeded in harmonizing the two delicate and often opposing considerations of securing a government that is strong, in the sense that power and responsibility are concentrated in the hands of the governing authorities, and yet one which, in its operations conforms, as regards all important matters, to public opinion.

If now the question is asked how England has been able to bring about this fortunate condition of affairs, we must seek an answer in a number of contributing facts. The first of these is that England began its career as a Monarchy in which all powers of government were at the start concentrated in the hands of the ruler; and that, only gradually, step by step, as one class after another became educated and capable of exercising political powers in a proper manner, was the privilege conferred upon the people of exercising a will in the conduct of their public affairs. The second fact is that England has at all times decisively rejected the principle of Democracy. There has never been 
any considerable portion of the population adhering to the theory that it was the function of the people to exercise directly political powers. No principle has been more firmly adhered to, or is at the present time more firmly imbedded in the British system, than that the political system of the country should be representative in character; that the people should exercise their political powers through representatives; and that it was the function of these representatives to determine in the first instance what should be the policies of the government, and to exercise all the powers in respect to the putting into effect of these policies. Thirdly, and as a condition without which such a system could not possibly prove successful, is the development of the principle that the powers so concentrated in the governing authorities should be exercised in the interests of the people and in general conformity with their wishes freely expressed. Finally, and equally imperative, is the establishment of the principle of accountability on the part of those exercising authority to the people in whose behalf such authority is exercised. This is secured in large part by the obligation that is imposed upon all government authorities of making a full exposition of the manner in which they have discharged their duties. Especially is this principle carried out in respect to all matters of public finance. Through a system of admirable reports full and detailed information is currently submitted to the people of all moneys received in the way of public dues or otherwise and how this money has been spent. These data, together with complete publicity in respect to parliamentary proceedings and all acts of executive officers, furnish that information which the people must have if an intelligent public opinion is to come into existence, and the people are to exert that general supervisory and approving authority which is properly theirs under a repre- 
sentative form of government. Only so long as the people can see that the government is being properly conducted and in their interest will they be content to acquiesce in the actual exercise of powers being in the hands of representatives and refrain from attempts to seize authority themselves.

The System of Political Parties in the United States. - In the United States political parties have taken quite a different form and have assumed quite a different rôle from what they do in England. This has arisen from the fact that, though the attempt was made to establish a government of a purely representative type, the pull towards Democracy has been too strong to be resisted. Denied any direct participation in the conduct of public affairs, the people have effected elaborate party organizations outside of the government through which they formulate their will regarding who shall be elected to office and what shall be the conduct in office of the persons so elected. These organizations have worked out elaborate systems of organization consisting of a long chain of committees, extending from the small local committees in local districts, through state committees representing the parties in the several states, to the central organizations known as national committees representing the parties in the country as a whole. They have their rules of procedure which determine how the memberships of these committees shall be selected, how their officers shall be chosen, what the powers of these officers shall be, etc. These rules further provide for the summoning of conventions for the purpose of selecting the candidates of the party for office in the states and in the national government and for the formulation of party platforms, as instructions to their candidates if they are elected.

It is not intended, by this statement, to convey the im- 
pression that officers, elected by the people, either directly or indirectly, are deprived of all individual initiative and discretion and are reduced to mere spokesmen for the purpose of putting into execution commands given to them. Necessarily the platforms adopted by the parties are general in terms and do not cover all questions that may arise. Quite a wide field is thus left in which the delegates may exercise their individual judgments in respect to the specific steps to be taken in carrying out the commands of the people. The impression that it is intended to convey is that the principle of popular participation in public affairs has been changed from the "representative" to the "agency," and that the tendency is for the representative bodies to become more and more mere organs for the registering of the decrees and the carrying out of action elsewhere determined.

Though one may believe, as many in the United States do, that this change from the representative to the agency idea is to be regretted, there is nothing in this change that, in a country with a highly intelligent electorate, and a long experience in Popular Government, necessarily means political disaster or even bad government, provided that certain conditions are met. These conditions are: that these political organizations shall confine their function to that of determining and expressing the public will and of formulating public issues in such a way that it is possible for the individual voter to choose between alternative candidates for elective offices and alternative lines of action; and that the same, or equal precautions shall be taken to ensure that these organizations are properly constituted and operated as are thrown around the organization and operation of the organs of government proper.

Unfortunately, neither of these conditions has been met 


\section{THE RÔLE OF POLITICAL PARTIES}

in the United States. Not content with determining public policies and who shall be the persons to fill the offices charged with the responsibility of seeing that these policies are actually adopted, party organizations have attempted to make, and to a considerable extent have succeeded in making, of themselves powerful agencies in respect to the work of executing these policies. They have thus sought to assume the same direction or order-giving function in respect to the administrative branch of the government that they do in respect to the legislative, that is, the policydetermining and law-enacting branch. This attempt has found expression in the dictation to administrative officers of what they shall do, how their offices shall be organized, what positions or stations shall be established, who shall be appointed to these offices, what salaries shall be paid, what work shall be undertaken, with whom contracts shall be made, what the terms of these contracts shall be, etc.

It may unhesitatingly be declared that this attempt on the part of political parties, or rather their organizations, to enter the administrative field is wholly bad. It has resulted in the introduction of what is known as the "spoils system"; that is, the system that looks upon public offices as the spoils of the political contest to be enjoyed by the victors. It is difficult to exaggerate the harm that has been done by the establishment of this practice. Fortunately the United States, after a long and bitter experience, has come to a realization of this fact and has begun to take the necessary steps for the correction of this evil. This it has done by taking the only effective means by which this evil may be eradicated; that, namely, of passing laws providing that only those persons shall be appointed to administrative offices as demonstrate their fitness through the giving of evi- 


\section{THE GOVERNMENT OF MODERN STATES}

dence of their capacity through examinations, or other means, and that, once appointed, their tenure of office shall be permanent or dependent only on good conduct.

The second condition that must be met, if political parties are to make of themselves real organs of government, in the sense of determining and controlling the actual conduct of governmental affairs, without becoming an evil and a danger to Popular Government, is that the same or equal precautions shall be taken to insure that these organizations are properly constituted and run as are thrown around the organization and operations of the organs of government proper. Here, too, the United States has failed to meet the requirements of the situation. The fact that political parties, as has been pointed out, have not been subject in the past to legal control has been taken advantage of by those making politics their chief concern in such a way as to make it possible for them to get the control of these organizations into their own hands, and thus to use the power and influence of these bodies for the advancement of their own selfish ends. This has resulted in the establishment of what is known as "ring rule" or "bossism" in the United States. Under this system a few men, who, for the most part, sought only their own advantage, actually dictated who should be the persons to be nominated as condidates for elective offices, and what should be party policies as expressed in the party platforms. More than this, taking advantage of the spoils system, they have dictated to executive and administrative officials who should be appointed to office, what stations or positions should be established, with whom contracts should be made, etc. This power they were able to wield, partly in consequence of the character of the rules providing for the organization and operation of the political machinery, the adoption of which 
they had secured, partly by the control of the party funds which was in their hands, and partly by the use of fraudulent practices of various descriptions.

Fortunately here, too, a beginning has been made to meet this situation of affairs. Within the last ten or fifteen years numerous laws have been placed upon the statute books of both our national and state governments having for their purpose to bring under control party organizations, practices and procedure. This legislation has taken the form of the enactment of the corrupt practices acts, of which mention has already been made, acts regulating the manner in which persons shall be nominated as candidates to be voted for at elections, acts regulating the manner in which officers of political parties shall be chosen, etc. This action is of the highest significance since it represents for the first time a recognition by law of the existence of these bodies as integral parts of the political system of the country and as such subject to legal regulation as are other government agencies.

Comparison of the Party Systems in England and the United States.- Though we have attempted to make known the fundamental features of the party systems in England and the United States, the real significance of these features can only be fully shown by bringing them into contrast. We have in these two systems the rather remarkable phenomenon of two countries, both populated by substantially the same race, both drawing their legal and social institutions and ideals from the same source, and both having the same fundamental end in view, that of achieving Popular Government, and yet developing widely divergent means of securing this end.

Both, in so far as deliberate planning is concerned, have, at the start, had a profound distrust of Democracy, and 
have sought to bring into existence that type of Popular Government known as representative. Here, however, the similarity ceases. In working out this problem the two countries have developed two political systems that rest upon principles that are utterly opposed to each other.

England has adhered rigidly to the principle of representation: the United States, notwithstanding its adoption of this principle, has, almost from the start, departed from it and gone over to the other principle. Steadily, the latter country has developed practices having as their effect, first to change the principle of representation from the representative to the agency, and then, going further, to convert its representative form of government to that of a Democracy or, at least, one in which the democratic element finds a constantly larger expression. This tendency is at the present time especially marked. A strong movement is now in progress for the introduction of the devices known as "the initiative," the " referendum," and the " recall," all three of which represent means by which the people may exercise their political powers directly instead of through either representatives or agents.

The result of this action has been to give to political parties an entirely different character and rôle in the two countries. In England these bodies are but means through which the people select their representatives and express their approval or disapproval of the policies adopted by them. Great care has been taken to prevent these bodies from becoming organs of government. In the United States, the reverse has been the case. Political parties have more and more succeeded in making of themselves the means through which public policies and legislative programs are formulated and have thus converted themselves into true organs of government. The English system concentrates in 
the same hands the policy-determining and the policy-adopting functions. The American system places these two functions to a large extent in the hands of separate bodies composed for the most part of different individuals. These two bodies moreover have no organic connection the one with the other. One is an organ inside, or rather constituting a part of the government proper; the other an organ outside of the government. The latter, moreover, composed as it is of persons holding no formal office and coming together only at infrequent intervals of time, functioning for a few days and then scattering, is of a character making it difficult if not impossible, to make effective the principle of accountability on its part for its acts. In like manner, the fact that the organ constituting a part of the government proper, the legislature, is called upon to adopt policies and measures in the determination of which it has not participated means that it cannot be held to full responsibility for its acts. That this condition of separation of functions and divided responsibility constitutes a grave defect in the American political system would seem to be self-evident.

The Two-Party System.-Before leaving this matter of a comparison of the two systems mention should be made of another feature which the two systems possess in common and which more than any one other feature marks off these systems from the party systems as they have developed in other countries. Reference is made to the prevalence in these two countries of what is known as the Two Party system. In both England and the United States the tendency has always been for the people to range themselves into but two great parties divided from each other by general issues. These issues, moreover, have represented rather general attitudes of mind towards political policies than differences in respect to particular issues. Political issues between the two 
parties there have always been, but these issues have, for the most part, been but the expression in the concrete of the general line of cleavage.

This feature of the political life of the two countries is not only characteristic of their political systems, but is believed by many to be essential to their successful operation. Certain it is that whenever a third or additional party has arisen to any degree of influence and power grave difficulties have immediately presented themselves. That the English system has worked with great friction since the rise of the Nationalist, or Irish Home-Rule, and the Labor parties, there can be no question. The existence of more than two great parties means that no one party will represent the majority opinion of the country and that government can only be carried on through two or more parties forming coalitions of a more or less temporary and artificial character At the best it represents a confusion of issues and a failure to secure that definite responsibility that is afforded by the two party system. It must be noted, moreover, that with the increasing scope of governmental activities, and the consequent multiplication of possible issues, there is a strong tendency for third parties to arise and constitute a permanent feature of the party system. Should this tendency prevail the system of political parties in England and the United States will undergo a profound modification. It is for this reason, among others, that we have stated that no country has as yet reached any final determination in respect to the character of political parties that it will have and the true rôle that they will play in the political life of the nation.

Collective versus Individual Responsibility.- Another feature characteristic of both the English and American 
systems of political parties and one which is of far-reaching importance is that in both these countries the idea of collective responsibility as distinguished from the individual responsibility of members elected to office has reached a high degree of development. By this is meant that individuals are voted for as representatives of their parties and of the policies for which such parties stand rather than on account of their individual opinions or merits. The result is that political policies are given preeminence over individual considerations. Political contests thus become contests between policies rather than men. The character of the latter are considered chiefly as it is believed they will prove the best agents for carrying out such policies. In England this principle is so firmly established that it is practically obligatory upon the individual members of the House of Commons to support the party program regardless of their personal opinions. They in effect receive an imperative mandate from those putting them in office to pursue this course. In the United States this movement towards collective or party responsibility has not as yet gone as far as this. What is known as independent voting still takes place to a considerable extent. The whole trend, however, is towards collective responsibility.

At first sight it might seem that a system under which representatives are compelled in many cases to vote against their convictions is difficult to defend. Examination, however, will show otherwise. Only as it obtains can clear-cut issues be brought before the people for determination and the decisions arrived at put into execution. If action is to depend upon a warring of hundreds of different wills it is difficult, if not impossible, to secure action that represents the real will of the people. One has but to compare the 
results under the system of collective responsibility with those secured under the contrary system to be convinced of the superiority of the former.

The System of Political Parties in France and Other Latin Countries of Europe.-In our study of the party systems in England and the United States, we have had the opportunity of examining and comparing two very distinct types of party organizations. We now pass to a consideration of the character of, and the rôle played by these bodies in France and other Latin countries in Europe. Here we will find a condition of affairs quite dissimilar from that existing in either of the countries we have been considering.

The most marked features of this dissimilarity consist in the failure of any one of these countries to develop a party system having those features which we have just shown are common to both the American and English systems. In France, and the same is true in other Latin countries in Europe, political parties and political organizations as understood in England and the United States scarcely exist. Political parties there are groupings inside rather than outside the government proper. If we make exception of the Socialist Party, there is no party organization as in England and the United States, having a formal organization outside the government proper. Each candidate practically puts himself in nomination and makes his own platform. It is sometimes said that there are as many political platforms in France as there are candidates for seats in the Chamber of Deputies. Far greater weight is thus given to the individual characteristics of the candidates than is the case in either England or the United States. Indeed in many cases, a party consists of little more than a political leader and the following that he can attach to himself.

The result of this condition of affairs is that a condition 
of collective party responsibility does not exist as is the case in England and the United States. The majority of votes in the Chamber of Deputies required for the proper conduct of governmental affairs is only secured through the cffecting of combinations and coalitions between small parties or groups led by political leaders. This support is often only secured through the meeting of the demands of these leaders for the adoption of particular pet measures, the expending of money in the districts represented by these leaders, or the appointment of such leaders or their followers to office. There is thus a strong tendency for parliainentary life to degenerate into a constant struggle on the f art of individuals for place and influence. In its worst phase it also brings about a strong tendency for the "Government," that is, the particular combination of parties or groups in power, to make an illegitimate use of its powers to win the support needed by it to retain its control. At the best this system gives to the conduct of governmental affairs an instability and a lack of that definiteness of purpose and policy that characterizes the two-party system as it prevails in the two English speaking countries.

Why France and the other Latin countries of Europe have thus failed to develop a party system under which the people can express their wishes regarding political policies in definite form is a question which it is difficult to answer. The explanation usually offiered is the peculiar temperament of the Latin race which does not permit of the compromises and adjustments necessary in order that individual wills may be merged in a general will. Though there may be some truth in this position, it does not seem necessary to appeal to the psychological factor. A sufficient explanation may be found in the briefness of the experience of these countries with a form of government calling for the playing 
of a prominent part by political organizations. We have seen that in both England and the United States political parties have been a spontaneous and unplanned development and that they have assumed a definite character only after an evolution of many years. It would be a matter of surprise did the Latin countries, having had but little experience with self-government, succeed in working out their problems of party organization in a shorter time.

The System of Political Parties in Germany.- Up to the present time we have been considering the place and functions of political parties in countries whose legal basis, and whose avowed political ideal is that of achieving Popular Government. If we turn now to countries whose constitutional systems do not rest upon this basis, but upon that of the head of the State being the original source of all political authority, we have evidently to deal with a different condition of affairs. Of such countries the chief example in Europe is the German Empire.

It would take us too far from our subject to attempt here to describe in detail the governmental system of that country. We will therefore have to content ourselves with the following brief statement of its more essential features. In Prussia, and in most if not all of the states constituting the present German Empire, the principle is firmly held that the King or other ruler is the fountain of all political authority. As a matter of political expediency, the ruler has in most, if not all cases provided for the establishment of a Parliament one of whose houses is composed in whole, or in part, of persons selected by the people, and having the function of representing the latter. These bodies, though occupying the same place in the governmental system are, however, quite dissimilar from the legislative assemblies existing under a Popular Government. Not only are they legally 
agents of the ruler rather than of the people, but their powers in respect to the determining or controlling of public policies and in enacting legislation are far from those of legislative chambers under a'Popular Government.

The first important limitation on their powers arises from the fact that in most, if not all, cases the body elected by the people forms but one of two chambers which together constitute the legislative assembly. The other is composed of persons holding office as the result of birth, official rank, appointment by the ruler, or some qualification other than that of selection by the people. The second limitation arises from the fact that these two chambers are rarely if ever coordinate in powers. In Prussia certainly, and in probably most of the other German states, the upper house is the senior partner and possesses far greater powers than the popular chamber. Finally the scope of the powers conferred upon the two chambers together is usually much less than that possessed by legislative assemblies in a Popular Government.

This policy in respect to the character and powers of the legislative assembly has been likewise adopted in the constitution of the German Empire. Its legislative assembly consists of two houses of which the upper house, the Bundesrat, is composed of persons owing their selection to the rulers of the several states and acting as their direct representatives, and is the real legislative organ of the government. The lower house, the Reichstag, is composed of members elected by the people, but has little more than the power to pass upon the proposals of the government which originate in, and must in all cases receive the final approval of the upper house. How relatively weak are the powers of this lower house is strikingly shown by the fact that its approval is not even essential to the passing of the budget 
providing for the expenditure of public funds. Prussia early established the doctrine that should the legislature fail to pass the budget, the King could promulgate a budget without such approval. This doctrine would undoubtedly be followed by the Empire should occasion require.

It follows from the foregoing that the popular chamber is relegated to the position of a body having negative rather than positive powers. Its cooperation with the ruler and the upper house will facilitate greatly the smooth conduct of public affairs, and for that reason attempts are made to meet its wishes in so far as this can be done without seriously interfering with the carrying out of policies deemed to be essential by the real rulers, the Emperor and the representatives of the heads of the German states. This cooperation, however, is not absolutely essential and consequently the government resulting is autocratic both in theory and largely in practice.

It is manifest that under a system such as this political parties will have quite a different character and play quite a different rôle than they do under a Popular Government. All that such bodies can do is to furnish the means of making known the wishes of the public: they cannot formulate programs the provisions of which are to be carried out by their agents. Even this function they can perform only imperfectly due to the fact that the electoral laws are of such a character as to throw the voting power largely in the hands of the upper classes, that is, those who by their interests are closely attached to the governing or official class. Political parties are thus neither an organ of government, as in the United States, nor the final seat of power as in England and France.

Apart from these considerations the character and rôle of political parties in Germany have been influenced, if not 
determined, by two other facts. The first of these is that Germany does not have a homogeneous population actuated by the same political interests such as exists in the other countries whose party systems we have been considering. Included within the boundaries of the German Empire are a considerable body of Poles, Danes, and Alsatians who resent bitterly domination by the Teutonic element. These races have had sufficient power to send to the Reichstag members whose dominating aim is to protect the interests of their people as Poles, Danes, or Alsatians. They constitute a group of so-called irreconcilables. They thus do not represent political parties in the sense in which that term is applied to a grouping of voters according to differences of opinion regarding matters of general policy. Added to this cleavage according to race lines is the antagonism existing between the Catholic and the Protestant elements of the population, an antagonism which has led to the formation of separate political parties along religious lines.

The second, and equally important feature of the party system in Germany is the fact that there exists in that country a not inconsiderable portion of the population which is opposed, not merely to the policies being pursued by the government but to that government itself. These people have constituted themselves into a party known as the SocialDemocratic party, whose fundamental aim is to change the form of government. We have here an explanation why the Kaiser and his Chancellor have from the start shown such a violent opposition to this party, an opposition which for years took the form of prohibiting by law their meetings or the publication of their party papers. During this period this party was treated as a seditious movement, and the policy of attempting to put it down through the enforcement of penal provisions against it was only abandoned because 


\section{THE GOVERNMENT OF MODERN STATES}

such action failed to accomplish its purpose. Though this party now constitutes the largest single party in the country it is still viewed by the government as a danger to the State and one to be combated in every way possible.

These several facts, that the government is one resting upon the principle of sovereignty being vested in the ruler instead of in the people; that the legislative branch is so organized as to give only a negative voice and that only a partial one, to the people; that the people are not homogeneous as regards their national character and aims; that special class interests are given precedence over those of the country as a whole; and that a large part of the population is opposed to the existing political system of the country makes impossible the existence of a party system such as is found in the other countries we have been considering.

The System of Political Parties in Switzerland.- In our examination of the party systems of England, the United States, France and Germany we have studied the rôle of political parties in countries having a Representative or Autocratic form of government. In Switzerland we have an opportunity to study the part played by such organizations in a country whose government approaches the type of a Democracy.

The distinguishing characteristic of the political system of Switzerland is that the people have elected to retain in their own hands, and to exercise directly, as large a part of their political powers as circumstances will permit. In certain of the smaller cantons, the voting population meets en masse to enact legislation. In others, where this is not feasible, they make use of devices known as the "initiative" and the "referendum." The initiative permits a certain number of voters to bring forward a legislative proposition to be submitted to the voters, and if the vote on it is favor- 
able it becomes a law. The referendum permits a certain number of voters to demand that a measure passed by the legislature shall be submitted to the voters to determine whether it shall be approved or disapproved, and if disapproved the measure becomes a nullity. Were it feasible to handle all affairs in this manner, there would be no necessity for a legislative assembly. As this is not feasible, provision is made in most of the cantons, and in the federal government, for such a body to which is intrusted the decision of all legislative matters not directly decided by the people. The power of the people to legislate directly is thus in the nature of a reserved power to be brought into play only in respect to important matters where there is doubt whether the legislative assembly is fully carrying out the wishes of the people.

Another distinguishing feature of the Swiss system is that the legislative assembly is made the organ for exercising on behalf of the people both legislative and administrative powers. The latter powers are exercised by the assembly through a permanent corps of administrative officials selected by it, who discharge their duties under its general direction. These officials are purely administrative officers and political considerations play no part in their selection or retention of office.

Under this system, where the people are able currently to bring forward and have considered specific measures, and where the legislative assembly can be made to respond immediately to the will of the people, there is no necessity for the formation of political parties such as exist in Popular Governments of the representative type. There is no need for the formulation of a political program either inside the government as in England, or outside the government as in the United States, and the organization of the voters in parties so as to insure a majority in the legislature to put 


\section{THE GOVERNMENT OF MODERN STATES}

this program into execution. As measures can be brought forward one by one for consideration, the voters divide differently at different times according as they favor or disapprove of the particular measure under consideration.

The result is that, though groupings of voters exist in order to promote certain policies, there are no political parties contending for power such as constitute the principal feature of the political life in other countries. The fact is that Switzerland has a form of government which may almost be designated as non-political. More nearly than in any other country the work of government is treated as a matter purely of business and to be handled as are the affairs of any large business concern. In one sense the Swiss system represents the ideal form of government. It would be extremely interesting to enter into a consideration of the reasons for this great success on the part of Switzerland in working out its political problem, did space permit. This brief notice has been made merely for the purpose of making clear that the problem of political parties in a Democracy, or in a government in which the democratic element finds so large expression, is fundamentally different from the problem as it presents itself in an autocracy or in a purely Representative Government.

The Rôle of Political Parties in the Establishment of Governments. - Consideration of this subject of the place of political parties in governmental systems should not be concluded without some mention of the peculiar problem that is presented in respect to the function of such organizations where the issues at stake are, not what policies shall be pursued by governments, but what form such governments shall have. At the present time the great political issue confronting a number of countries of which Russia 
and China are leading examples, is the form of government that they should have.

It is evident that there is a fundamental difference between the people organizing themselves in opposing parties with a view to having the government, the existence of which is accepted by all, pursue this or that line of conduct and their effecting organizations having for their purpose the maintenance or overthrow of that government. In the first case we have a common loyalty to the government actuating all parties. In the second we have at least one party seeking to oppose, not merely the policy of the government which is in control, but that government itself. It is inevitable that under such circumstances, such a party will have a disloyal if not an actually seditious character. At best it will seek to embarrass the existing government in the effort to establish a stable and efficient political system. At the worst it will be a revolutionary movement seeking to subvert the existing government, if necessary, by force.

We have here a fundamental distinction upon which it is impossible to lay too great force. As President Lowell in his notable work on the Government of England very acutely says: ${ }^{1}$

In countries where popular control of public affairs has endured long enough to be firmly established, an opposition is not regarded as in its nature unpatriotic. ... In the newer Democracies, such as France and Italy, there are large bodies of men whose aims are revolutionary, whose object is to change the existing form of government, although not necessarily by violent means. These men are termed "irreconcilables" and so long as they maintain that attitude, quiet political life with a peaceful alternation of parties in power is an impossibility. ... If the opposition is not to be regarded as revolutionary, its object must not be of that character, either in the eyes of its own adherents, or in those of other people.

1 A. L. Lowell: "The Government of England," Vol. I, pp. 437-438. 
If this is true of the countries mentioned by President Lowell, and it is of course true only in a limited sense, how much more is it true of countries such as Russia and China which have not yet reached a stage of political equilibrium.

History furnishes abundant illustrations of the desirability of avoiding the attempt to frame a constitutional system through the play of party contests and of having political powers strongly centralized during the formative period. When Rome entered upon the preparation of her famous Twelve Tables all political powers were for the time being vested in the Decemvirs. The United States in framing its constitution entrusted this task to a convention which sat behind closed doors with the deliberate purpose of preventing this important act from becoming the subject of factional discussion and contests. While the governmental systems of the insular possessions of the United States, Porto Rico and the Philippines, were being framed, all powers were concentrated in the hands of the Military Governor. No one who has had any experience with the conduct of public affairs in those possessions can doubt but that the establishment of this military dictatorship during this formative period was not only necessary from the standpoint of maintaining order, but from that of permitting the work of framing a scheme of civil government to proceed deliberately and calmly with reference to the interests of the whole country uninfluenced by the pressure of party contentions. Neither can any one doubt that the maintenance of this military regime at that time greatly expedited the final establishment of a civil government under which provision was made for large powers of popular participation in the conduct of public affairs. 
INDEX 


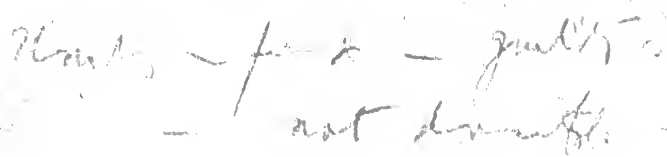




\section{INDEX}

Absolutism, prime characteristic of, 13; principle of, 43 .

Accounts and reports, in governments, 390; importance of a proper system of, 406 .

Adams, John Quincy, on the action of the Pilgrims constituting themselves a body politic, Io.

Administration, a distinct branch of government, 23I-233; function of, defined, 232; lack of provision for the separate exercise of in the United States, 250. Administrative branch, relation of chief executive to, $35 \mathrm{I}$; functions of, 385 ; distinguished from the executive branch, 385 , 386 ; non-political character of, 385-386; organization of, 390391 ; need for reorganization of, in the United States, 393; need for creation of central service to control, 393 ; problems of personnel in, 396-404; problems of material in, 404-406; problems of business practice and procedure in, 406-407.

Administrative districts versus political subdivisions, I84-I86.

Althusius, Johannes, 49.

Amendments, constitutional, distinction between initiation, adoption and ratification of, 134 ; initiation of, 134, methods of procedure in, 134; adoption of, 135 ; ratification of, $135-137$, in representative government, 136 , in Japan and Germany, I4I ; pro- posal and ratification of in the United States, 214.

American colonies, doctrine of popular sovereignty in, 50.

American Constitutional System, by W. W. Willoughby, cited, 5 , 8, I4, I5, 2I, 22.

American Judicature Society, establishment of, 372.

American State Legislatures, by Paul Reinsch, 136.

Anarchistic school of political thought, beliefs of adherents of, 170.

Annual Conferences of Governors of the States, 22I.

Annals and Memoirs of the Court of Peking, by Bland and Backhouse, 74 .

Argentina, establishment of multiple government in, 203 .

Articles of Confederation, did not provide for constitutional convention, 105.

Assembly, right of, I6r.

Aucoc, Conference sur L'administration, cited, 232.

Australia, an example of multiple government, $2 \mathrm{II}$; territorial distribution of powers in, $21 \mathrm{I}$.

Australian ballot system, 286.

Austria, constitution of, granted by ruler, 97 .

Austria-Hungary, desire of peoples of, for independence, 10.

Autocracy, described, 37 ; represented by Japan, Russia and Prussia, 39, 40; modern type of, 43 ; existing types of, 44 ; merits 
of, 53; unity of will in, 54; its advantages over popular government, 55-59; concentration of administrative authority in, 56 ; defects and dangers of, 59; bureaucracy in, 60; militarism in, 62; menace of, to other states, 64; political parties in, 65,430 ; absolute versus limited, $42-46, \quad 73-75$; revision and amendment of constitutions in, 140-142.

Belgium, popular sovereignty declared in constitution of, $5 \mathrm{I}$; constitution of not granted by ruler, 97.

Bland and Backhouse, Annals and Memoirs of the Court of $\mathrm{Pe}$ king, 74; China under the Empress Dowager, 74.

Bill of Rights, in England, not superior to ordinary law, 78 .

Bodin, Jean, 49.

Body Politic, definition of, 6; constituted by Pilgrims in 1620, 9 .

Brazil, establishment of multiple government in, 203.

Brown, Rome G., Address on Recall of Judges before the Min- nesota State Bar Association, cited, 380.

Bryce, James, Studies in History and Jurisprudence, cited, 42.

Budget, attitude of Parliament of Great Britain towards, 238; preparation and enactment of, in Great Britain, 259, in the United States, 260.

Bundesrath, German, originator of legislative measures, 296.

Bureaucracy, in an autocracy, 6263 ; two meanings of term, 397398; Prussian, 398-399.

Burgess, Political Science and Constitutional Law, cited, I5.
Cabinet, President's, development of, 145 .

Calhoun, speeches on nature of the Union, 24.

Cambridge University, graduation from, a requirement for first division clerkships, $40 \mathrm{I}$.

Canada, unique territorial distribution of powers in, $2 \mathrm{II}$; an example of multiple government, 2II ; bicameral legislature, 320.

Census Bureau, division of the United States made by, 224, 225.

Central Government, dependence of on state governments in the United States, 215; relation to the state government, 214-22I; should be superior to states, 215 . Chief Executive, qualifications of, 340-34I; selection of, 34I-343; hereditary versus elective systems, 342; election of, by popular vote, $343-344$, by the legislature, 344 , by a specially constituted electoral college, 345-346; succession to the office of, 346348, in the United States, 347; independence of, 348-350; limitations on, in the United States, 349 , as commander-in-chief of armed forces, 350 ; as administrator-in-chief, 35I; relations of, to the electorate and legislature, 35I, to other branches of government, $350-352$.

China, referred to as a state with impaired sovereignty, 19; a sovereign state, 20 ; belief in divine right of kings, $4 \mathrm{I}$; popular sovereignty declared in constitution, 5I ; Revolution of 19II, 68; conditions in prior to I9II, 73; republic of, established by revolution, IOI; revolt in, part of widespread political movement, I06; constitution of, departments of government specified 
in, II2; ratification of constitutions by electorate undesirable in, I33; establishment of unitary government in, 204; creation of National Assembly in, 297, recommendations respecting, 299; establishment of Presidential government in, 358 .

China Under the Empress Dowager, by Bland and Backhouse, 74.

Civil War, in the United States, a contest over nature of the state, 24 .

Collectivistic school of political thought, $174-176$.

Colonies and Dependencies, growth of self-government in, 68.

Commentaries on the Constitution of the Empire of Japan, by Baron Ito, cited, 40.

Committee on Foreign Affairs, of the Senate, conference with the President on treaties, 3 II.

Common Law, of England, 364. Commons, Proportional Representation, $328 \mathrm{n}$.

Communistic school of political thought, principles of, 177.

Comparative Administrative Law, by Frank J. Goodnow, 370 n.

Confederate States of America, their right to be designated a state, 18.

Conference sur L'administration, by Aucoc, cited, 232.

Congress, of the United States, validity of acts of, determined by Supreme Court, I2O; designates method of ratification of constitutional amendments, 138 ; membership of, I39; must approve agreements between states, 22I; influence of the President on, 244; participation of, in executive power, 248; primary source of administrative power, 252; lack of power of appointment, 256; attempt of, to control improper practices in elections, 288; as a constitutional convention, 29I ; functions of, $29 \mathrm{I}$; as a canvassing board and electoral college, 293; as an organ of public opinion, 294-301 ; as a board of directors, 30I-305, 388-394; as an organ of legislation, 305-309; as an executive council, 309-312; as a high court of justice, 312-313; composition of the two houses of, 316 ; its powers of direction and control, 387.

Constituent Assembly, of France in $187 \mathrm{I}$, as provisional government, I04.

Constituent Powers, defined, II9; distinction from legislative powers, 120 ; complete surrender of, by electorate, I2I ; surrender of, exemplified by English system, I23; surrender of with maintenance of distinction between constituent and legislative powers, exemplified by French system, 126-128; participation in, by people, 128 .

Constitution of China, provisional, attempt to make certain features unamendable, I43; protection of individual rights in, 156 ; specifies administrative departments, II2.

Constitution of France, cited, 126 ; amendment procedure, 126 ; attempt to make certain provisions unamendable, I43.

Constitution of Japan, cited, 39, 40.

Constitution of Prussia, 40.

Constitution of Switzerland, cited, 156; protection of individual rights in, 156 . 
Constitution of the United States, cited, 88; not entirely written, 94; adoption of possibly revolutionary, I05; does not specify administrative departments, II2; model of proper drafting, II4; amendment of, I37-140, regarded as too difficult, II8, part of states in, 214; Art. V, cited, I38, I42; difficulty of effecting changes in, I39; attempt to make certain provisions unamendable, 142 ; informal modification of, I44; property rights in, 159; procedural rights guaranteed by, 163 ; conditions at time of adoption of, 197 ; superiority of central government in, 2I5; extradition provisions, Art. IV, Secs. I-3, cited, 22I ; Art. II, Sec. 2, cited, 25I ; denial of vote on account of color, etc., prohibited, 275; guarantee of republican form of government to states in, cited, 282 , invoked in Dorr's Rebellion, 282; amendments authorizing income tax, popular election of senators, and prohibition, 292, 293; provisions for impeachment, $3 \mathrm{I} 2,3 \mathrm{I} 3$; chief executive, qualifications of, $34 \mathrm{I}$, election of, 345 , succession to office of, 347 .

Constitutions, definition of, 6; methods of establishment of, 95, by deliberate creation, $97-98$, by process of gradual evolution, 98-100, by revolution, 100-102; formulation of, 93-106; written and unwritten, 94; of Japan, Prussia, Austria, granted by rulers, 97; generality the primary principle of drafting, $\mathrm{II}_{3}$; modification of, 107-146; formal versus informal, II8; flexibility, a requisite of, 108-118; stability, a requisite of, 108-113; amend- ment of, III, i34; revision and amendment of, 128-138, 292, distinction between, I28-129, in autocracies, I40-I42; of federal government, special problems involved in revision and amendment of, 137 ; certain provisions of, declared unamendable, I42I43, in China, France, and United States, I42-I43; dual function of, I49-I5I.

Constitutional Conventions, convening of, I3o.

Constitutional government, defined, 77-79; test of, 78 .

Constitutional Government in the United States, by Woodrow Wilson, cited, 77, 295, 303.

Constitutional History of England, Maitland, cited, 307 n, 308. Constitutional Law of the United States, by W. W. Willoughby, cited, $25 \mathrm{I}$.

Correlation of the Organization of Congress with that of the Executive, by W. F. Willoughby, $305 \mathrm{n}$.

Council of State, French, an advisory body, 309 .

Courts, duplicate system of, in the United States, 219; procedure of, as opposed to that of administrative bodies, 362 ; as bodies to determine or construe law, $364-367$; as bodies to prevent infractions of law and violation of rights, $367-368$; as bodies to administer property, 368-369; systems of, in France, Germany, England and the United States, 369; non-contentious functions of, 369 ; administrative, in Europe, 369370 , in the United States, 370; organization of system of, 360 373; state, system of, in the United States, 37I ; classifica- 
tion according to relative rank, 372 ; of equity, versus courts of law, 376 .

Covenant entered into by $\mathrm{Pil}$ grims in $1620,9$.

Cuba, referred to as a state with impaired sovereignty, I9; a sovereign state, 20.

Czecho-Slovaks, desire of, for autonomous state, Io, 27.

Darwin, influence of his theory of evolution on politics, II6.

Declaration of Independence, influence of on revolution, Io2.

Delaware, ratification of constitutional amendments in, 136 .

Democracy, definition of, $80-81$; limitations of, $81-83$; dangers of, 82 ; in the United States, contest of, with representative government, 89-90; fear of, in early constitutions, II7; political parties in, 434.

Democratic-Representative Government, 86.

Dependencies and Colonies, growth of self-government in, 68.

Dicey, Law and Public Opinion in England in the Nineteenth Century, cited, $18 \mathrm{n}, .176 \mathrm{n}, 370 \mathrm{n}$.

Divine Right of Kings, doctrine of, $4^{\mathrm{I}-42}$, questioned, 48 .

Dorr's Rebellion, 280-284.

Duma, significance of the summoning of, 43 .

\section{Economy and Efficiency in the} Government Service, message of President Taft, 3I I n.

Elections, of President and Vice President of the United States, I45; majority versus plurality requirement in, 329-331.

Electorate, surrender of constituent powers by, 12I; in England, approval necessary to change political system, 124, unable to initiate proposals for constitutional changes, 125, composition of in beginning of nineteenth century, 279; ratification of constitution by, I33; powers of, 149; a distinct branch of government, 229-23I ; rôle of, in monarchies, 229; functions of in popular government, 230 ; defined, 273; composition of, 273 , a matter of expediency, 276, tendency in the United States, 280 ; the possessor of legal sovereignty, 277; right of people to revolt against, 278; procedure to be adopted by, 284-288.

Ely, French and German Socialism, I7I $\mathrm{n}$.

England, a sovereign state, I9; belief in divine right of kings, 42 ; government of, after Revolution of $\mathrm{I} 688$, oligarchic type, 47 , purest example of representative government, $86-87$, evolution of, 99, influence of legislative organization and procedure on, 335; establishment of popular sovereignty in, $49,5 \mathrm{I}$; selection of king, 49; constitution of, unwritten, 94; location of sovereignty in, 123; constitutional conventions in, 124; constitutional system of, informal modification of, $\mathrm{I} 44$; major political divisions of, 222 ; personal union of powers in, 237 ; independence of judiciary in, 239; common law of, 265, 364 ; broadening of electoral franchise in, 275; franchise acts of 1867,1884 , and 1885 and reform act of 1832,275 ; electoral conditions in beginning of nineteenth century, 279; reform act of 1832 forced by threat of 
revolution, 279; militant suffragists of, 280; decision of contested elections in, 287 ; character of the legislature in, 289 ; drafting of legislation in, 295; ordinance making power in, 307; impeachment in, 312 ; operation of bicameral legislative system in, 319; dissolution of legislature in, 33I ; executive powers in, 339; responsible government in, 354; successful operation of, 358,359 ; system of courts in, $370,37 \mathrm{I}$; reform of judicial system of, 371 ; administration of justice in, 375 ; judiciary in, until the Revolution of 1688,382 ; Treasury Department of, a service of general overhead administration, 394 ; personnel system of, described, $401-402$; political parties in, 4I4-419, 424; Parliament, see Parliament of England.

England: Its Political Organization and Development and the War Against Germany, by Edward Meyer, cited, 3I n.

Equality before the Law, I60-I6I. European Police Systems, by Raymond B. Fosdick, cited, 6r.

Executive branch, functions of, 385 .

Federal government, problem of constitutional revision in, 137.

Federalist, The, cited, 88.

Federation, a result of American Civil War, 24.

Federation and confederation, distinction between, 22-23.

Fields, Factories and Workshops, by Kropotkine, I I I $\mathrm{n}$.

Filipino Republic, its right to be designated a state, 18 .

Finns, desire of, for independence, Io.
Fosdick, Raymond, European Police Systems, cited, 6r.

France, popular sovereignty not directly declared in constitution, $5 \mathrm{I}$; after Revolution of 1789 , a popular government without laws, 77; first republic established by revolution, I0o; formulation of the constitution of, I04; constituent assembly of I871, ro4; Constitutional Law on Organization of Public Powers, Sec. 8, cited, I43; major political divisions of, 222 ; election of chief executive in, 343,344 ; responsible government in, 355 ; system of courts in, 369; system of political parties in, 428; constitution of, see Constitution of France.

Freedom of speech rght of, I6r.

French and German Socialism, by Ely, I7I n.

French Revolution, fighting incident to, I02.

Fundamental Laws of the Russian Empire, cited, 40.

Germany, belief in divine right of kings, 42 ; foreign policy of, as illustrating advantage of autocracy, 56 ; cause of administrative efficiency in, 57 ; location of administrative authority, 58 ; molding of public opinion through bureaucracy in, 62; social-democratic party in, 65,433 ; conversion from autocracy to popular government, 70; constitution of, Art. 78 , cited, 141 ; constitutional amendment in, $14 \mathrm{I}$; a union of formerly independent states, 202 ; increase of strength of national government in, 205 ; territorial distribution of powers in, 210; judicial system of, 218 , 
369; use of state administrative systems by central government in, 218; major political divisions of, 222; dissolution of legislature in, 33I; attempt to establish responsible government in, 356 ; political parties in, 430-434; governmental system of, 430 .

Goodnow, Frank J., Social Reform and the Constitution, cited, 207; Comparative Administrative Law, $370 \mathrm{n}$.

Government, definition of, 6 ; unitary, II; its distinction from state, II, I5; multiple or federal, II; an agent of the state, I5; unity of, $35,36,18 \mathrm{I}$; types of, according to location of sovereignty, autocracy, oligarchy, and popular, 37; distinction between autocratic and popular, 45; oligarchic type of, 46 ; popular type of, 47 ; comparison of autocratic and popular, 52-68; moral aspects of, 59 ; types of, according to exercise of sovereignty, 7279; establishment of, through formulation of constitutions, 93 ; powers of, 149, functional distribution of, 227-267, classification of, 228 , distribution of territorially, by whom made, I89190, distribution of, two-fold method, 183, territorial, 183226; jurisdiction of, determination of, two-fold character of problem, I5I ; functions of, I69177; unitary versus multiple, 190-193; electoral branch of, 27I-288; executive branch of, 338-359; judicial branch of, $360-$ 384; administrative branch of, 385-407. Popular, see Popular government.

Government of Union of Powers, character of the legislature in, 289.
Government of Authority versus Government of Law, 72.

Government of England, by A. Lawrence Lowell, cited, 409, 437. Governor of a state, as administrator-in-chief, 394.

Grand Jury, composition and procedure of, 374 .

Great Britain, see England.

Greece, ancient, democracy in, 82. Greek Republic, the origin of popular sovereignty, 47.

Hobbes, Thomas, 49.

House of Representatives, Committee on Rules, 336.

Humphrey, Proportional Representation, $328 \mathrm{n}$.

Income tax, amendment to United States constitution, authorizing, 292.

Individual rights, guarantee of, not essential to constitutional government, 78; methods of providing, I5I-I56, advantages of statement of, in constitutions, I56; nature of, 157 .

Individual rights and natural law, I66-I68.

Individual rights versus social rights, I64-I66.

Individualistic school of political thought, 172-175.

"Initiative," in the United States, 90.

Ito, Baron, of Japan, Commentarics on the Constitution of the Empire of Japan, cited, 40.

Jackson, election of, in 1824,89 ; exercise of removal power by, 257.

Japan, constitution of, cited, 39, 40, I4I ; government of, auto- 
cratic type, 39; foreign policy of, as illustrating advantage of autocracy, 56; responsible ministry in, $7 \mathrm{I}$; revolution in, significance of, 75 ; constitution of, granted by ruler, 97 ; constitutional amendment in, $14 \mathrm{r}$; attempt to establish responsible government in, 356 .

Jenks, Edward, Law and Politics in the Middle Agcs, cited, 306.

Johnson, President, attempted impeachment of, 256, 348 .

Jones, C. L., Statute Law Making, cited, 323.

Judicial branch, relation of chief executive to, 351 ; functions of, 360.

Judicial procedure, $373-378$; in criminal cases, accusatorial versus inquisitorial systems, 374 .

Judiciary, of the United States, legislative functions of, 246 ; sole possessor of judicial power, 249 ; independence of, $250,378-$ 384; peculiar status of, 380 ; method of selecting federal and state judges, 383 ; superiority of federal over state, 384 .

Judiciary and Progress, by William H. Taft, cited, 38r.

Jugo-Slavs, desire of, for autonomous state, 10, 27; deliberate organization of government by, 98.

Jury, petty, institution of, 362 ; composition of, and rules governing, 376 .

Kendall versus United States, 253. Kropotkine, Prince, a scientific anarchist, I7I ; Fields, Factories and Workshops, I7I $\mathrm{n}$.

Law, defined, 6, 302; an attribute of the state, I2-14; private, largely found in decisions of courts, 365 ; conflict of, in the United States, 366 ; determination of constitutionality of, 367 ; versus equity, 375 .

Law and Politics in the Middle Ages, by Edward Jenks, cited, 306.

Law and Public Opinion in England in the Nineteenth Century, by Dicey, cited, $18 \mathrm{n}, \mathrm{I} 76 \mathrm{n}, 370 \mathrm{n}$. Leacock, Stephen, The Limitations of Federal Government, cited, $212 \mathrm{n}$.

Legislatures, state, ratification of constitutional amendments by, 140 ; character of, in a unitary government, 289, in a government of union of powers, 289; in England, 289; in a representative government, 290 ; problem of organizing and operating, 290 ; functions of, 29I ; unicameral versus bicameral, 313, 31732I ; bicameral, historical development, 3I4, in United States, 318, in England, 319, in Canada, 320 , in a multiple government, 321 ; selection of members, of the upper house, 319, method of, $324-327$, district versus general ticket system, 326; length of term of members of, 322-324; size of, 322 ; composition of, $32 \mathrm{I}$; qualifications of members of, 324; minority or proportional representation in, 327-329; duration of, 33I-333, in England and Germany, 33I ; sessions of, 332 ; powers and privileges of, 333-335 ; procedure of, 335337 ; in German states, 430-431. Legislative Notes and Reviews, American Political Science Review, November, I915, cited, I $88 \mathrm{n}$.

Legislative Powers, distinguished from constituent powers, 119. 
Limitations of Federal Government, The, by Stephen Leacock, cited, $2 \mathrm{I} 2 \mathrm{n}$.

Lowell, A. Lawrence, Government of England, cited, 409, 437.

Madison, James, on distinction between representative government and democracy, 87.

Magistracy, definition of, 6 .

Magna Charta, not superior to ordinary law, 78.

Maitland, F. W., Constitutional History of England, cited, 307 n, 308.

Manchester School, philosophy of, I73.

Matériel, problems of, 404-406.

Maximillian, Prince, address to Reichstag, 69, 356 n.

Mexico, establishment of multiple government in, 203.

Meyer, Edward, on conception of the state, 3I.

Ministry, in Great Britain, three capacities of, 240 ; its relation to Parliament, 240; legislative powers of, 295.

Militarism, defined, 62.

Minority representation, 328 .

Monarchy, popular government possible in, $5 \mathrm{I}$.

Montesquieu, on the constitutional separation of powers, 264 .

Multiple government, in the United States, Germany and Switzerland, 19I, 202; versus unitary government, 192-200; due almost wholly to historical reasons, 20I-202; establishment of, in Central and South America, 202-203; increase of strength of central government in, 204-206; an intermediary stage, 206; distribution of powers in, 208-212, territorially, 197; interrelations of governments within, 212-213; disadvantages of, 212; administrative systems possible in, 217; bicameral legislative system in, 321.

Multi-party system, 329.

National Assembly, creation of, 297, in China, 297, 299, in a popular government, 298; reason for general failure of, 297; functions of, $30 \mathrm{I}$; as a creator of law, 305.

Natural law and individual rights, I66-I68.

Netitralized states, 19-22.

New England, towns of, democracy in, 82 ; evolution from democracy to representative government in, 100 .

Non-sovereign states, 19-22.

Oligarchic type of government, 46. Oxford University, graduation from, a requirement for first division clerkships, 401 .

Parliament, English, as elector of the king, 49; powers of, respecting the throne, 49; supremacy of, 78; exercises entire sovereign power of people, 87, r23; inability of, to change political system unless approved by electorate, 124; attitude of, towards the budget, 238; possessor of all legislative powers, 238 ; its attitude towards matters of administration, 239; respecting the removal of judges, 239; relation of the ministry to, 240 ; as an organ of public opinion, 294; no longer a legislative body, 295; as a board of directors, 303 ; development of, into a legislative organ, 306-308; first successful legislature, 3I4; develop- 
ment of bicameral system in, 315 ; struggle for privileges immunities, 333.

Party organizations, in the United States, 89.

People, definition of, 6 .

Persia, referred to as a state with impaired sovereignty, 19; revolt in, significance of, 75, part of widespread political movement, Io6.

Personnel, problems of, 396; bureaucratic system of in Prussia, 397-400; English system of described, 40I-402; system in the United States, 402-403.

Petition, right of, I6r.

Petition of Rights, not superior to ordinary law, 78 .

Philosophy of Labor Legislation, by W. F. Willoughby, cited, $18 \mathrm{n}$.

Pilgrim Republic, The, by Goodwin, cited, ro n.

Pilgrims, on Mayflower, constituting body politic, 9 .

Poles, desire of, for autonomous state, 10, 27; deliberate organization of government by, 98 .

Political divisions, kinds of, $\mathrm{I} 88$.

Political parties, as organs of public opinion, 294 ; a recent phenomena, 408; viewed as an evil, 408-410; rôle of, in modern governments, 408-438; inside and outside the government, distinction between, $4 \mathrm{II}-4 \mathrm{I} 3$; in England, 4I4-419, 424; in the United States, 146, 419-423, 424; two party system, 425-426; collective versus individual responsibility, 426-428; collective responsibility of, in England, 427, in the United States, 427; system of, in France and other Latin countries of Europe, 428-430 ; in Germany, 430-434; in Switzerland, $434-436$.
Political principles, difference of, in governments, 4,5 .

Political Rights, I6I-162; nature of, I6r ; limitations on the exercise of, 162 ; fundamental purpose of, 162 .

Political Science and Constitutional Law, by Burgess, cited, I5 $\mathrm{n}$.

Politics, influence of theory of evolution upon, II7.

Pope, supreme authority of, 42,48 . Popular government, 47; possible in a monarchy, $5 \mathrm{I}$; a question of fact, $5 \mathrm{I}$; source of administrative authority in, 57 ; superiority of to autocracy, 67 ; steps to be taken by, to secure administrative efficiency, 67; more difficult to organize and operate than an autocracy, 68; struggle in Germany and Japan for, 697I ; absolute versus limited, 7577 ; need of law in, 76 ; democratic versus representative types, 80-90; electorate in, 273 ; steps in the establishment of, 298; political parties in, 423.

Popular sovereignty, doctrine of, historical development of, 4751 , origin of, 47 , basis for French Revolution, 50, in American colonies, 50; establishment in England of, 49; not expressly declared in constitution in England, the United States and France, $5 \mathrm{I}$; declared in constitution of China and Belgium, 5I ; tendency to prevail, $68,69$.

Porto Rico, location of administrative powers in, 58 ; similarity to German government, 59.

Post Office Department, accountable to Congress, 252.

President of the United States, powers of, veto, 243 ; legislative, 246,25 I, 296 , executive, 248 , ad- 
ministrative, 254,394 ; nominating, appointing and removal, 255; direction and control, 388 . Presidential government, establishment of, in China, 358.

Principles of Government Purchasing, by A. G. Thomas, $406 \mathrm{n}$. Privy Council, of England, 309. Problem of a National Budget, by W. F. Willoughby, $389 \mathrm{n}$.

Problems of Readjustment after the War, by W. W. Willoughby, cited, 45 .

Procedural rights, I62-164; defined, I63; constitutional guarantee of, in the United States, I63.

Prohibition, amendment to United States constitution, 293.

Property rights, $158-160$; in constitution of the United States, 159.

Proportional representation, 328.

Proportional Represcntation, by Humphrey, $328 \mathrm{n}$; by J. R. Commons, $328 \mathrm{n}$.

Provisional government, problems of, 103-105.

Prussia, government of, autocratic type, 40; constitution of, 40, granted by ruler, 97 ; personnel system of, $397-400$.

Prussian Theory of Government, The, by W. W. Willoughby, cited, $28 \mathrm{n}$.

Prussian Theory of the State, The, by W. W. Willoughby, cited, $28 \mathrm{n}, 30 \mathrm{n}$.

Public officials, definition of, 6.

Puritan movement, overthrew papal supremacy in England, 48.

Puritans, and the Stuarts, 49.

Quasi-sovereign states, 19-22.

"Recall," in the United States, 90.

Recall of Judges, address on, before the Minnesota State Bar
Association, by Rome G. Brown, cited, 380.

"Referendum," in the United States, 90.

Reform Act of 1832 , enactment of, 280.

Reformation, overthrew papal supremacy on the continent, 48.

Reichstag, address to, by Prince Maxmillian, 69; as an organ of public opinion, 296.

Reinsch, Paul, American State Legislatures, cited, 136 .

Representation, representative versus agency type of, 4I3-4I4; in England, the representative type, 4I7, 4I8; in the United States, the agency type, 420.

Representative government, 83-86; defined, 83; a device for applying principles of popular government, 84; England the purest example of, 86 ; contest of, with democracy in the United States, 89-90; ratification of constitutional amendments in, 136 ; character of the legislature in, 290.

Responsible government, defined, 352; examples of, in France, England and Italy, 352; forma-• tion and duration of the ministry in, 353 .

Responsible government versus presidential government, 356 .

Revolution of 1688 , contest over location of sovereignty, 38 .

Revolution of I9I I, in China, significance of, 75 .

Revolutions, dual character of, IOI-IO2; difficulties of establishment of government by, I02I06; of Turkey, of Persia, of Russia, of China, of America, illustrative of difficulty of establishing constitutions by revolution, I03; right of, 284 . 
Rhode Island, Dorr's Rebellion in, 280-284.

Roman Republic, the origin of popular sovereignty, 47.

Rome, empire of, nominally republican, 48.

Rousseau, Jean Jacques, writings of, on popular sovereignty, 50; The Social Contract, 50; influence upon French Revolution, IOI.

Russia, desire of the peoples of, for independence, Io; government of, autocratic type, 40; Fundamental Laws of the Russian Empire, cited, 40; Czar of, 43 ; revolution of 1917,68 ; at present, a popular government without law, 77 , only nominally a constitutional government, 79; soviet government of, established by revolution, ror; revolt in, part of widespread political movement, 106.

Schools of Political Thought, fundamental distinction between, I70.

Senate of the United States, power of, treaty-making, $249^{\circ}, 310$, - appointing, 3ro; as an executive council, 309; committee on foreign affairs of, conference with President on treaties, 3 II.

Senators, popular election of, amendment to United States constitution, 293.

Short ballot, movement for, in United States, 90.

Social Contract, The, by Jean Jacques Rousseau, 50.

Social-Democratic Party, in Germany, 433.

Social Reform and the Constitution, by Frank J. Goodnow, cited, $20 \%$.

Socialistic school of political thought, attitude of, towards functions of government, 176 .

Society, definition of, 5-6.

South Africa, establishment of unitary government in, 203.

Sovereignty, as an attribute of the State, I4, I5, 20; defined, 20, I49; lack of power not an impairment of, 20 ; unity and indivisibility of, $2 \mathrm{I}$; location of, in a federation and confederation, 22, importance of determining, 36 , 38, three principles respecting, 37, in governments of atthority, 73 , in a democracy, $8 \mathrm{r}$, in England, I23; in oligarchic government, 46 ; in popular government, 47; in representative government, 85 ; legal versus political, 277 ; popular, see Popular sovereignty.

Spain, major political divisions of, 222.

Spencer, Herbert, writings of, on individualism, 173 .

Spirit of the Laws, The, by Montesquieu, 264.

Spoils system, in the United States, attempts to abolish, 42I. State, distinction between state and government, 5, I5, necessity for, II ; definition of, 6,26 ; nature of, 7-32, importance of question of, 27, 28; essential characteristics of, 7 ; as an abstraction, 7 ; steps toward creation of, at present time, Io; as an entity, II, I2; attributes of, law, I2-I4, force or compulsion, I2, sovereignty, I4, I5; possessor of supreme authority, I4, I5; unlimited powers of, I5, 16; significance of creation of, 15, I6; relation of, to individual liberty, I8; contest over the nature of, cause of Civil War, 24; as possessor of personality, 24, 25; 
identical character of, in all cases, 25-26; theory of, organic, 25, Anglo-Saxon, 28, comparison of Anglo-Saxon and Teutonic, 28-32, German, 29.

State and government, distinction between, 5-6.

State Department, control of, by the President, 252.

State government, relation to central government, 2I4-22I.

State legislatures, in Germany, 430-43I.

States, non-sovereign, quasi-sovereign, with impaired sovereignty, neutralized, I9-22; of the United States, agreements between, must be approved by Congress, 22I, interrelations of, $22 \mathrm{I}$.

Statute Law Making, by C. L. Jones, cited, 324.

Stuarts and the Puritans, 49.

Stuart Kings of England, theory of divine right of, 38 .

Studies in History and Jurisprudence, by James Bryce, cited, 42. Supreme Court, of the United States, power to pass on acts of Congress, 120; decision of, in Kendall versus United States, 254; respecting two governments in Rhode Island, 283.

Switzerland, cantons of, democracy in, 82 , evolution from democracy to representative government in, IOO; initiation of constitutional amendments in, I35; constitutional revision or amendment in, I37; a union of formerly independent states, 202 ; increase of strength of national government of, 205 ; territorial distribution of powers in, 210; executive powers in, 339; political parties in, 434-436. System of Financial Administra- tion of Great Britain, by W. F. Willoughby, W. W. Willoughby, and S. M. Lindsay, 293 n.

Taft, William H., Economy and Efficiency in the Government Service, 3II n; Judiciary and Progress, cited, 38r.

Tenure of Office Acts of 1867 and I 869, 256.

Thomas, A. G., Principles of Govcrnment Purchasing, $406 \mathrm{n}$.

Treasury Department, of the United States, directly accountable to Congress, 252; of England, a service of general overhead administration, 394.

Turkey, revolution in, significance of, 75 ; revolt in, part of widespread political movement, 106.

Ukrainians, desire of, for independence, ro.

Union versus Separation of Powers, constitutional, 233-235, reasons for preferring separation, 264 ; distinction between personal and organic, 236; comparison of United States and Great Britain in respect to, 237, 262; relative merits, $26 \mathrm{I}-268$.

Unitary government, examples of, I9I ; distribution of powers territorially in, 192; local self-government possible under, 200; adopted by South Africa and China, 203-204; movement towards, 207 ; advantages of, 212; character of legislature in, 289.

Unitary versus Multiple government, I92-200; problem of local self-government under, 200-20I.

United States, a unitary state notwithstanding its federal form of government, Ir ; a sovereign state, 19; popular sovereignty not directly declared in consti- 
tution, $5 \mathrm{I}$; administrative inefficiency in, 57; government of, representative in principle, $87-$ 88 , established by revolution, IOI, influence of legislative organization and procedure on, 336 ; ratification of constitutions by electorate desirable in, 133 : initiation of constitutional amendments in, 135 ; a union of formerly independent states, 202; movement to counteract disadvantages of multiple government in, 205 ; territorial distribution of powers in, 210 ; inter-governmental relations in, 213; duplicate judicial system in, 219; duplication of administrative agencies by central and state governments in, 219; major political divisions of, 222 ; political subdivision of, at present defective, 223, proper method, 224; exercise of legislative power by judiciary in, 247 ; distribution of administrative powers in, 259; a government of union of powers organically and personally, 260; question of electoral franchise in, 275; growth of electorate in, 280 ; decision of contested elections in, 287 ; growth of legislative power of President in, 296; impeachment in, 312 ; bicameral legislatures, 316,318 ; executive powers in, 340 ; chief executive, election of, $145,344,345$, succession to office of, 347 , independence of, 349; administrative tribunals in, 370; system of courts in, 370, 37I ; method of selecting federal and state judges in, 383 ; need for reorganization of administrative services in, 393; personnel system of, 402-403; agency type of representation in, 420; political parties in, 424 . Congress of, see Congress of the United States. Supreme Court of, see Supreme Court of the United States.

Venice, government of, oligarchic type, 46.

Voltaire, influence of, on French Revolution, Ior.

Wallace, influence of his theory of evolution on politics, II6.

War, present, one of political principles, 4, 5, different conceptions of state cause of, 27; FrancoPrussian, of 1870-7I, I04.

War Department, control of, by President, 252.

Webster, Daniel, speeches on nature of union, 24 ; on political versus legal sovereignty in American law, 283.

William of Orange, 38 ; election of, 99 .

Willoughby, W. F., The Philosopliy of Labor Legislation, cited, I8 $\mathrm{n}$; Correlation of the Organization of Congress with that of the Executive, $305 \mathrm{n}$; Problem of a National Budget, $389 \mathrm{n}$.

Willoughby, W. W., on definitions of terms employed in political science, 5, 6; The American Constitutional System, cited, I3, 14, 21, 23; The Prussian Theory of the State, cited, $28 \mathrm{n}$; The Prussian Theory of Government, cited, $28 \mathrm{n}$; on the conception of the state, 30 ; Problems of Readjustment after the War, cited, 45.

Willoughby - Willoughby-Lindsay, System of Financial Administration of Great Britain, 239 n.

Wilson, Woodrow, Constitutional Government in the United 
States, cited, 77, 295, 303; on the English Parliament, 294. 'Woman Suffrage, 276.
Yuan Shi Kai, his attempt to convert China into a constitutional monarchy, 342 . 


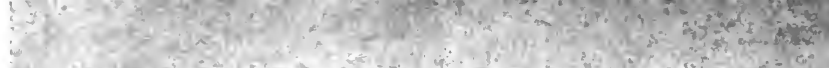

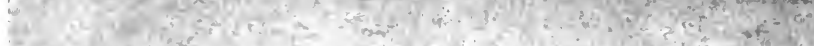

है

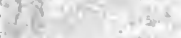

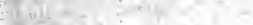

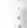




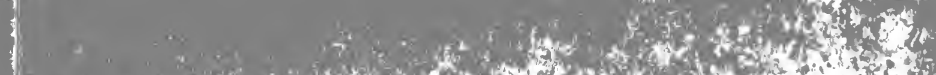

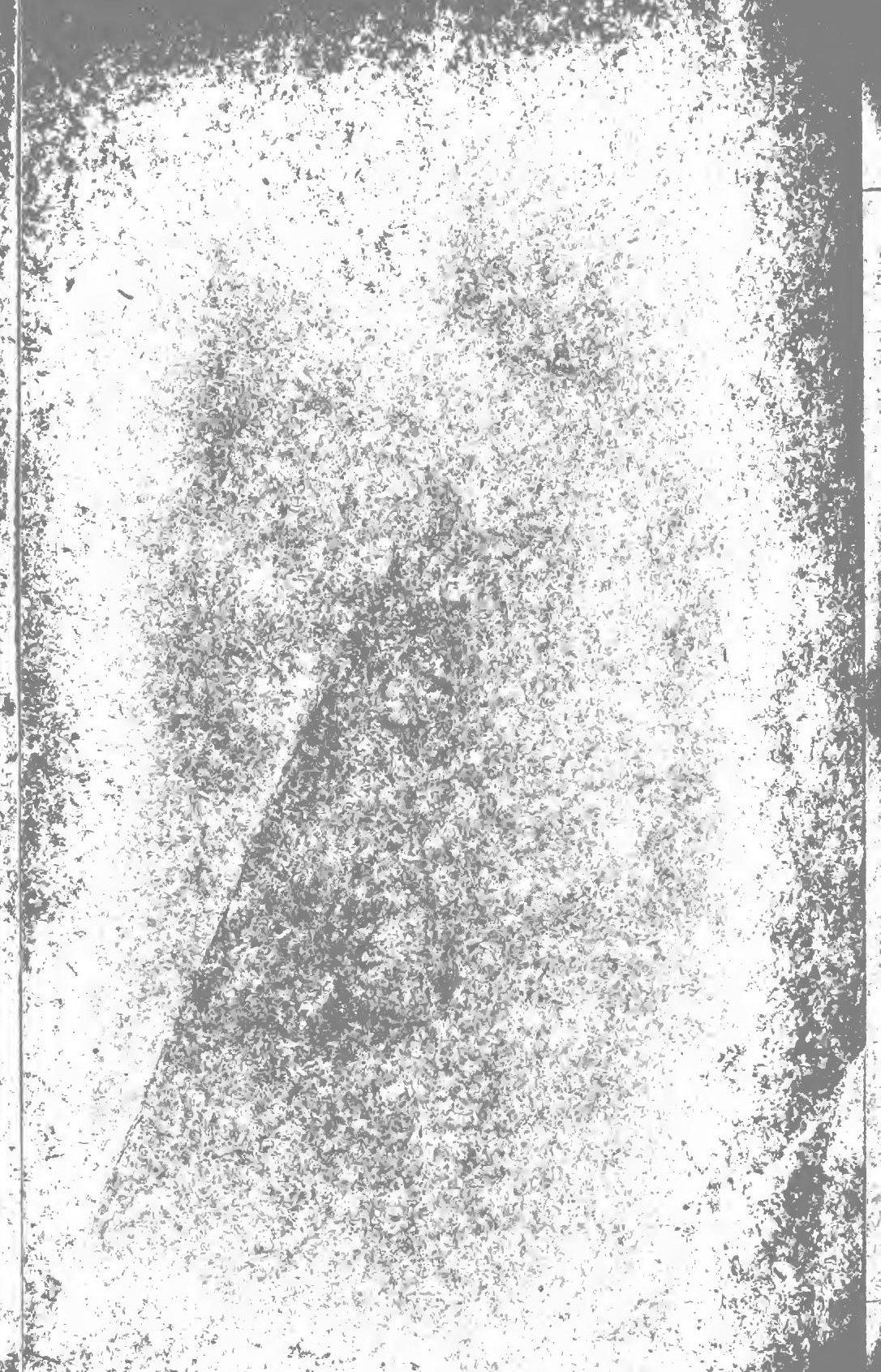




\section{DAY USE}

RETURN TO DESK FROM WHICH BORROWED

\section{LOAN DEPT.}

This book is due on the last date stamped below, or on the date to which renewed.

Renewed books are subject to immediate recall.

\begin{tabular}{|c|c|}
\hline & RECEIVED \\
\hline $8 \mathrm{Hov}^{159 \mathrm{Ml}}$ & AUG $17^{\circ} 66^{\prime}-\ddot{2}$ PM \\
\hline$p=c: D$ & LOAN DEPT. \\
\hline$\left.A C T^{\prime}\right)=1059$ & SEP 171978 \\
\hline & MER OIR NAY 2 \& 78 \\
\hline $2050 b^{1}<5 C$ & AUG 221983 \\
\hline REC'D LD & BEC. CIR. SEP3O \\
\hline MAR 2 '65-11 AM & \\
\hline JUL 27196677 & \\
\hline 27 Ang & \\
\hline $\begin{array}{l}\text { LD } 21 A-50 m-4,59 \\
(A 1724810) 476 B\end{array}$ & $\begin{array}{l}\text { General Library } \\
\text { University of California } \\
\text { Berkeley }\end{array}$ \\
\hline
\end{tabular}



